\title{
norden
}

Nordisk Ministerråd

\section{Trafikafgifter og klimapåvirkning}

Hvordan sænker vi bilernes $\mathrm{CO}_{2}$-udledning?

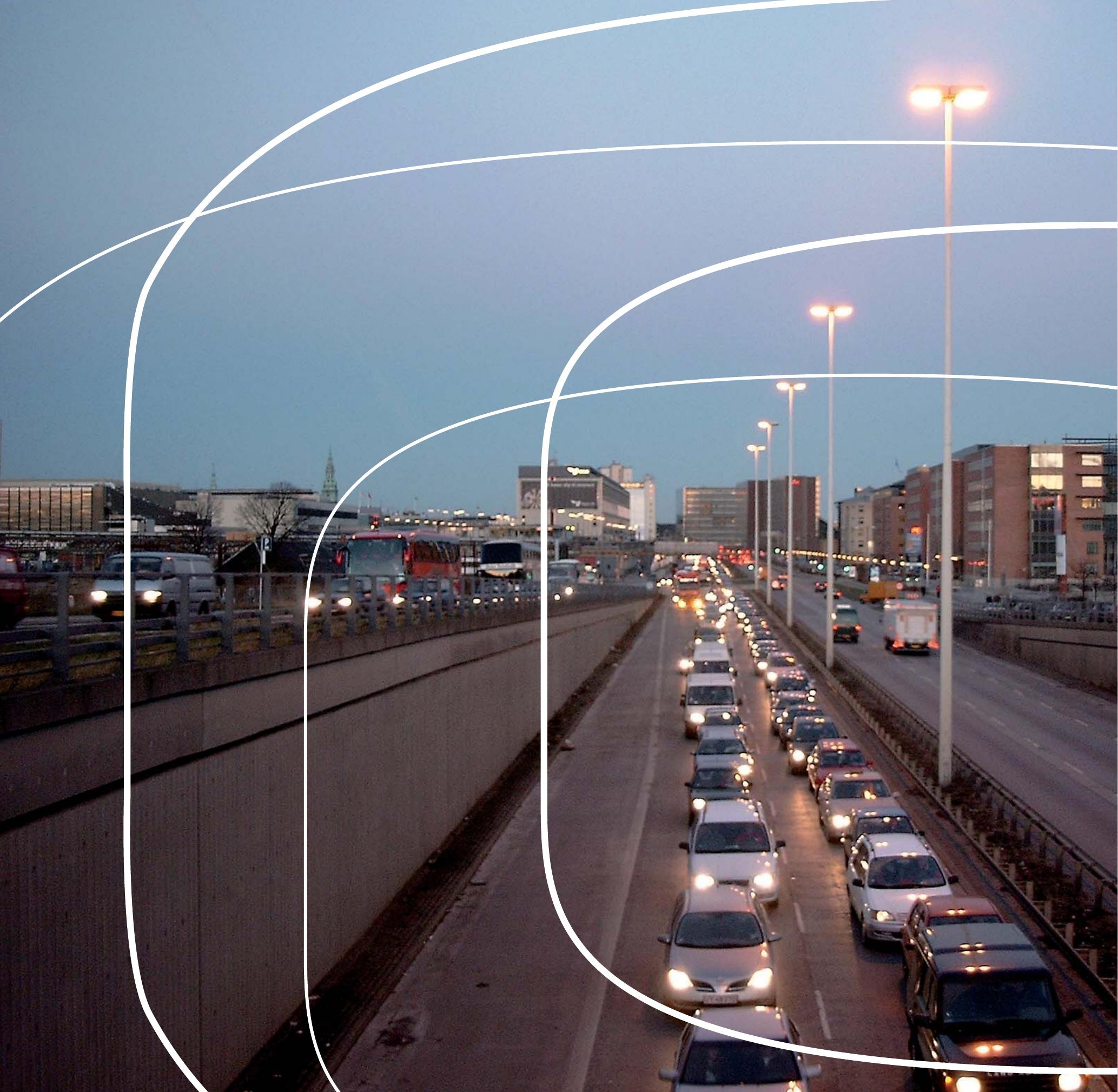


4 norden 



\section{Trafikafgifter og klimapåvirkning}

Hvordan sænker vi bilernes $\mathrm{CO}_{2}$-udledning?

Det Økologiske Råd, Naturvernforbundet og

Naturskyddsföreningen 
Trafikafgifter og klimapåvirkning

Hvordan sænker vi bilernes $\mathrm{CO}_{2}$-udledning

TemaNord 2008:587

(c) Nordisk Ministerråd, København 2008

ISBN 978-92-893-1760-3

Tryk: Ekspressen Tryk \& Kopicenter, fås kun som Print-on-demand

Omslag: DesignKonsortiet

Layout: DesignKonsortiet

Trykt på miljøvenligt papir som opfylder kravene i den nordiske miljøsvanemærkeordning.

Publikationen kan bestilles på www.norden.org/order. Flere publikationer på

www.norden.org/publikationer

Printed in Denmark

Nordisk Ministerråd

Store Strandstræde 18

1255 København K

Telefon (+45) 33960200

Fax (+45) 33960202

www.norden.org

\section{Nordisk Råd}

Store Strandstræde 18

1255 København K

Telefon (+45) 33960400

Fax (+45) 33111870

Rapporten er udarbejdet af Det Økologiske Råd i Danmark, Naturskyddsföreningen i Sverige og Norges Naturvernforbund for Nordisk Ministerråd

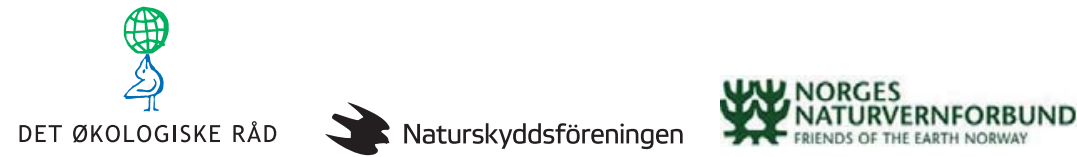

Det nordiske samarbejde

Det nordiske samarbejde er en af verdens mest omfattende regionale samarbejdsformer. Samarbejdet omfatter Danmark, Finland, Island, Norge og Sverige, samt de selvstyrende områder Færøerne, Grønland og Åland.

Det nordiske samarbejde er både politisk, økonomisk og kulturelt forankret, og er en vigtig medspiller i det europæiske og internationale samarbejde. Det nordiske fællesskab arbejder for et stærkt Norden $i$ et stærkt Europa.

Det nordiske samarbejde ønsker at styrke nordiske og regionale interesser og værdier i en global omverden. Fælles værdier landene imellem er med til at styrke Nordens position som en af verdens mest innovative og konkurrencedygtige regioner. 


\section{Forord}

Denne udredning om muligheder for at reducere klimapåvirkningerne fra person- og varebiltrafikken primært via afgifter og skatter er finansieret af Nordisk ministerråd, udvalg for miljø og økonomi.

Opgaven er udført af et samarbejde mellem Det økologiske Råd i Danmark, Naturskydds-foreningen i Sverige og Norges Naturvernforbund. Det er udført i samarbejde mellem Hans Ege og Christian Ege (Det Økologiske Råd, Danmark), Torhildur Kristiansdottir og Holger Schlaupitz (Norges Naturvernforbund), Magnus Nilsson (Naturskyddsföreningen, Sverige) og med inddragelse af Erja Heino, Suomen luonnonsuojeluliitto, SLL (Finlands Naturskyddsförbund) og Orkusetur og Umferdastofa i Island.

Rapporten er skrevet på dansk, norsk og svensk i landenes afsnit i del I. Resten er skrevet på dansk, bortset fra afsnittet om EU-lovgivning (svensk). I indledningen findes en lille liste med centrale ord på landenes sprog.

Nordisk Ministerråd og dennes miljø- og økonomigruppe tager ikke ansvar for rapportens konklusioner og anbefalinger. 


\section{Indholdsfortegnelse}

Del o Forord og indledning

Del I EU-regulering af beskatning, brændstofforbrug og salg af person- og varebiler

Del II Beskatning af person- og varebiler i de enkelte nordiske lande 1. Danmark

1. Målsætninger

2. Grundfakta om bilbestand, brændstofforbrug, miljøbelastning mv.

3. Beskatning af drivmiddel

4. Beskatning af køretøj

5. Øvrige skatter og skattefradrag

6. Hvordan styrer skatterne trafikkens miljøbelastning?

2. Norge

1. Målsætninger

2. Grundfakta om bilbestand, brændstofforbrug, miljøbelastning mv.

3. Beskatning af drivmiddel

4. Beskatning af køretøj

5. Øvrige skatter og skattefradrag

6. Hvordan styrer skatterne trafikkens miljøbelastning?

3. Sverige

1. Målsætninger

2. Grundfakta om bilbestand, brændstofforbrug, miljøbelastning mv.

3. Beskatning af drivmiddel

4. Beskatning af køretøj

5. Øvrige skatter og skattefradrag

6. Hvordan styrer skatterne trafikkens miljøbelastning?

4. Finland

1. Målsætninger

2. Grundfakta om bilbestand, brændstofforbrug, miljøbelastning mv.

3. Beskatning af drivmiddel

4. Beskatning af køretøj

5. Øvrige skatter og skattefradrag

6. Hvordan styrer skatterne trafikkens miljøbelastning?

5. Island

1. Målsætninger

2. Grundfakta om bilbestand, brændstofforbrug, miljøbelastning mv.

3. Beskatning af drivmiddel

4. Beskatning af køretøj

5. Øvrige skatter og skattefradrag

6. Hvordan styrer skatterne trafikkens miljøbelastning?

Bilag 1: Danske afgiftssatser 
Del III Sammenligning mellem de nordiske lande

1. Priser på udvalgte person- og varebiler

2. Salg af person- og varebiler efter energiforbrug/vægt

3. Bestand af person- og varebiler i alt og pr indbygger

4. Kørsel i person- og varebiler i alt og pr person, herunder privat erhvervskørsel hvis muligt

5. Brændstoftyper, forbrug i alt

Del IV Potentialer for $\mathrm{CO}_{2}$-besparelser

1. Analyser af potentiale ved skift til mere energieffektive biler

2. Diskussion af krav til miljøvenlige biler

Del V Styringsmidler til fremme af køb og brug af biler med mindre energiforbrug

1. Beskatning efter energiforbrug (registreringsafgift og ejerafgift)

2. Beskatning af varebiler brugt til personkørsel og af personbiler i firmabrug

3. Andre afgifter og skatter, herunder kørselsafgifter

4. Subsidier til brug af alternative brændstoffer

Del VI Konklusion og english summary 


\section{Indledning}

Baggrund. Transporten bidrager med voksende mængder $\mathrm{CO}_{2}$ til atmosfæren. I forhold til internationale mål og aftaler bliver det stadig vanskeligere at holde hånden over transportens bidrag til drivhuseffekten. Senest bliver det i EUkommissionens forslag af 23.01.08 til EU's energi- og klimapakke fastlagt, at landene skal reducere $\mathrm{CO}_{2}$-udledningen fra "landbrug, individuel boligopvarmning og trafik" med hvert sit \%-mål, f.eks. for Danmarks vedkommende $20 \%$ inden 2020. Hvis EU indgår en international aftale om generelt 30\% reduktion, vil bl.a. Danmarks mål på dette område blive hævet. Det er ikke længere muligt at opfylde reduktionsmålene, uden at der også sker reduktioner for trafikken ud over de krav til forbedringer af bilernes motorteknik, som måske vedtages i EU i 2008. Det ville pålægge landbrug og individuel boligopvarmning umulige besparelsesmål, hvis der her skulle kompenseres for en fortsat stigning i trafikkens udslip.

Indhold. Projektet vurderer mulighederne for primært via afgifter og skatter, at reducere $\mathrm{CO}_{2}$-bidraget fra person- og varebiler. Der ses på afgifter på at købe, eje og bruge en bil, og der er vidt forskellige løsninger i de nordiske lande. Der har også været gennemført en række radikale ændringer gennem årene. Det giver visse muligheder for at vurdere de forskellige afgifters virkning over for hinanden. Dog skal man være opmærksom på, at en række andre faktorer også påvirker trafikanternes adfærd ved bilkøb og brug af bil - faktorer, som også kan være ganske forskellige i de nordiske lande. Forhold som lokalisering, teknologisk udvikling, konjunkturer og socioøkonomi har betydning for udviklingen i trafikkens klimapåvirkning. Dette behandles ikke her, men der kan sagtens være et betydningsfuldt samspil mellem f eks afgifter og lokalisering.

Samtidig redegøres for eventuelle forslags effekt på andre skadelige emissioner.

\begin{tabular}{lll} 
Dansk & Svensk & Norsk \\
Registreringsafgift & $\begin{array}{l}\text { Bilaccis, försäljningsskatt, } \\
\text { registreringsskatt }\end{array}$ & Engangsafgift \\
\hline Grøn ejerafgift / vægtafgift & Fordonskatt & Årsavgift \\
\hline Provenu & Indtäkt & Inntekt \\
\hline Kilometerskat ${ }^{*}$ ) & Kilometerskatt & Kilometerskatt \\
\hline Varebiler & Lätta lastebilar & Varebiler \\
\hline Brændstofafgift & Drivmedelskatt & Drivstoffavgift \\
\hline Befordringsfradrag & Reseavdrag & Pendlerfradrag \\
\hline Firmabiler (gule plader) & Förmånsbilar & Firmabiler \\
\hline Taxa, hyrevogn & Taxibilar & Taxi / drosje \\
\hline $\mathrm{CO}_{2}$, kuldioxid & Koldioxid & $\mathrm{CO}_{2}$, karbondioksid \\
\hline $\mathrm{NO}_{\mathrm{x}}$, kvælstofilter & kväveoxider & Kvælstofilter \\
\hline
\end{tabular}

*) EU: Vägtull

Ordliste - centrale begreber 
Tilsvarende er der i landeafsnittene i del I brugt landenes valuta, mens der i den øvrige rapport er omsat til danske kroner af hensyn til sammenligneligheden. Her kan nævnes kurserne:

\begin{tabular}{l|c|c|c|c}
\hline For 100 & Norske kr. & \multicolumn{1}{c}{ Svenske kr. } & \multicolumn{1}{c}{ EURO (Finland) } & \multicolumn{1}{c}{ Islandske kr. } \\
\hline $\begin{array}{l}\text { Får man i } \\
\text { danske kr.: }\end{array}$ & 94,64 & 79,52 & 745,67 & 7,1234 \\
\hline
\end{tabular}

I rapporten sammenlignes priser, adfærdspåvirkning mv. direkte mellem de nordiske lande. Der tages ikke hensyn til eventuelle forskelle i velstand, indkomster, boligpriser mv., idet det antages, at forholdene trods alt ikke er så forskellige mellem de nordiske lande, og idet inddragelse af disse forhold kunne gøre arbejdet meget omfattende og uigennemskueligt. Der bringes dog her et enkelt eksempel på sådanne forholds betydning:

Selv om prisen på drivstof i f.eks. Norge er blandt de højeste i Europa målt i kroner pr. liter, så er prisen blandt de laveste i Europa, hvis man beregner, hvor mange liter drivmiddel en industriarbejder i gennemsnit kan købe for den løn, hun eller han får for en times arbejde. En industriarbejder i Norge får f.eks. i gennemsnit næsten dobbelt så meget benzin for en times arbejde som en industriarbejder i Spanien, eller mere end 7 gange så meget diesel som en industriarbejder i Polen. Det er kun i Danmark, at en industriarbejder får mere drivstof for lønnen end i Norge, se tabel 1 og 2.

Der gøres opmærksom på, at beregningerne er baseret på timefortjenesten i 2006 og drivstofpriserne i april 2008. Dette indebærer, at sammenligningen vil være unøjagtig på nivå, men den giver en god indikation af de relative variationer i købekraft. 
Tabell 1: Timefortjeneste for industriarbeidere, bensinpris og liter pr. arbeidstime for utvalgte land.

\begin{tabular}{lcrc} 
Land & $\begin{array}{c}\text { Timefortjeneste 2006 } \\
\text { NOK pr. time }\end{array}$ & $\begin{array}{c}\text { Pris 95 blyfri bensin } \\
\text { april 2008 } \\
\text { NOK pr. liter }\end{array}$ & $\begin{array}{c}\text { Liter bensin } \\
\text { pr. arbeidstime }\end{array}$ \\
Danmark & 164 & 11,05 & 14,85 \\
\hline Norge & 177 & 12,44 & 14,23 \\
\hline Irland & 119 & 9,45 & 12,60 \\
\hline Tyskland & 127 & 11,21 & 11,33 \\
\hline Storbritannia & 121 & 10,71 & 11,30 \\
\hline Sverige & 115 & 10,51 & 10,95 \\
\hline Osterrike & 101 & 9,83 & 10,28 \\
\hline Finland & 114 & 11,24 & 10,14 \\
\hline Nederland & 121 & 12,37 & 9,78 \\
\hline Belgia & 103 & 11,30 & 9,19 \\
\hline Frankrike & 89 & 10,97 & 8,12 \\
\hline Italia & 88 & 10,97 & 8,02 \\
\hline Spania & 66 & 8,98 & 7,35 \\
\hline Portugal & 31 & 11,11 & 2,79 \\
\hline Tsjekkia & 26 & 9,80 & 2,65 \\
\hline Polen & 19 & 9,96 & 1,91 \\
\hline
\end{tabular}

Kilde: NOU 2008: 10 Om grunnlaget for inntektsoppgjørene 2008, EU Oil Bulletin 14/04/2008, Norsk Petroleumsinstitutt, Statistisk sentralbyrå, Norges Bank og Finansdepartementet. ${ }^{2}$

Tabell 2: Timefortjeneste for industriarbeidere, autodieselpris og liter pr. arbeidstime for utvalgte land.

\begin{tabular}{lrrr} 
Land & $\begin{array}{r}\text { Timefortjeneste 2006 } \\
\text { NOK pr. time }\end{array}$ & $\begin{array}{r}\text { Pris autodiesel april } \\
\text { 2008 NOK pr. liter }\end{array}$ & $\begin{array}{c}\text { Liter autodiesel } \\
\text { pr. arbeidstime }\end{array}$ \\
Danmark & 164 & 10,52 & 15,58 \\
\hline Norge & 177 & 12,05 & 14,69 \\
\hline Irland & 119 & 9,59 & 12,41 \\
\hline Tyskland & 127 & 10,59 & 11,99 \\
\hline Nederland & 121 & 10,31 & 11,73 \\
\hline Finland & 114 & 9,96 & 11,45 \\
\hline Belgia & 103 & 9,54 & 10,79 \\
\hline Sverige & 115 & 10,84 & 10,60 \\
\hline Storbritannia & 121 & 11,59 & 10,44 \\
\hline Osterrike & 101 & 9,91 & 10,19 \\
\hline Frankrike & 89 & 10,23 & 8,70 \\
\hline Italia & 88 & 10,69 & 8,23 \\
\hline Spania & 66 & 9,40 & 7,02 \\
\hline Portugal & 31 & 9,92 & 3,12 \\
\hline Tsjekkia & 26 & 10,01 & 2,60 \\
\hline Polen & 19 & 9,85 & 1,93 \\
\hline
\end{tabular}

Kilde: NOU 2008: 10 Om grunnlaget for inntektsoppgjørene 2008, EU Oil Bulletin 14/04/2008, Norsk Petroleumsinstitutt, Statistisk sentralbyrå, Norges Bank og Finansdepartementet.

\footnotetext{
2 Drivstofpriserne er hentet fra EU Oil Bulletin, Norsk Petroleumsinstitutt og Statistisk sentralbyrå, mens lønningsdata er hentet fra Teknisk Beregningsutvalg.
} 


\section{DEL I: EU-regulering af beskatning, brændstof- forbrug og salg af person- og varebiler}

EUs lagstiftning innehåller få regler som direkt berör beskattningsfrågor. En viktig förklaring är att beslut om skattefrågor kräver enighet i ministerrådet mellan medlemsstaternas regeringar, dvs varje medlemsstat har i realiteten veto. Eftersom vissa medlemsstater, inte minst Storbritannien, i princip är stark motståndare till att EU lagstiftar om skatter, stoppas regelmässigt de flesta förslag till EU-omfattande skattelagar.

Frånvaron av en harmoniserad lagstiftning betyder att skattesatserna varierar kraftigt mellan länderna - det gäller både t ex drivmedelsskatter men också olika försäljningsskatter. Beträffande försäljnings- eller registreringsskatterna varierar skattesatserna från o till 180 procent ${ }^{3}$ av försäljningsvärdet! ${ }^{4}$ Av figur 0 framgår punktskatter på drivmedel inom EU25 i oktober 20075. (Under en övergångsperiod har de länder som senast anslöt sig till unionen rätt att underskrida de lagstadgade miniminivåerna.)

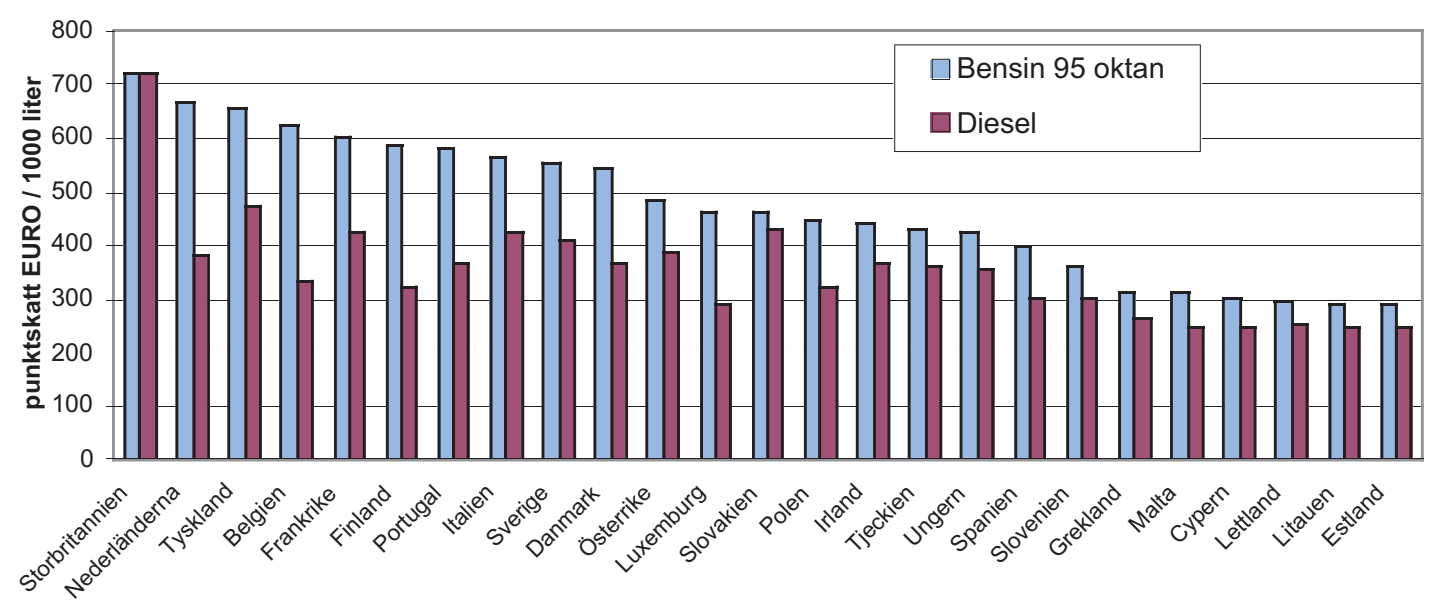

Figur 0. Punktskatter på drivmidler i EU-landene 
EU-kommissionen har under åren presenterat ett antal analyser där den hävdar att bristen på skatteharmonisering mer eller mindre starkt försvårar den s k fria rörligheten för varor och tjänster. Kommissionen har också lagt fram en lång rad konkreta förslag om harmonisering av skattereglerna, som dock regelmässigt stoppats av ministerrådet. Några exempel:

- 2002 föreslog Kommissionen en stegvis harmonisering av dieselskatterna ${ }^{6}$

- 2005 föreslog Kommissionen att alla registreringsskatter successivt skulle slopas och istället ersättas av årliga fordonsskatter, differentierade efter fordonens koldioxidutsläpp ${ }^{7}$

De EU-skatteregler som trots allt gäller finns dels i energiskattedirektivet och det s k eurovignettdirektivet, dels i form av allmänna regler för hur medlemsstaterna via skatterabatter $\mathrm{m} m$ kan stimulera t ex snabbintroduktion av ny avgasreningsteknik eller renare drivmedel.

\section{Energiskattedirektivet (2003/96/EG)}

Energiskattedirektivet började gälla 2004 och ersatte då i första hand det s k mineraloljedirektivet. I direktivet fastslås miniminivåer för skatter på bl a bensin och diesel som gäller från 2004 resp 2010 (se tabell ovan).

Direktivet tillåter länderna att på olika sätt undanta vissa sektorer från drivmedelsskatter eller att differentiera skatterna:

- Medlemsländerna behöver inte beskatta drivmedel till lokal kollektivtrafik.

- All spårtrafik kan undantas från beskattning.

- Det är tillåtet att skattebefria miljövänliga och/eller förnybara drivmedel för särskilda "pilotförsök".

- Vissa biodrivmedel, bl a etanol och rapsolja (RME), kan undantas från skatt. $^{8}$

- Det är tillåtet med nedsättningar av skatten på diesel som används i jordbruk, arbetsmaskiner $\mathrm{m} \mathrm{m}$.

- Länderna kan tillämpa olika skattesatser för diesel som förbrukas i fordon som väger mera än resp mindre än 7,5 ton ("kommersiell/icke-kommersiell trafik").

Eurovignettdirektivet (1999/62/EG med ändring 2006/38/EG)

I det s k eurovignettdirektivet regleras dels miniminivåer för den årliga fordonsskatten på tunga fordon, dels hur medlemsländerna kan ta ut vägavgifter eller vägtullar för tung trafik (normalt fordon över 3,5 ton).

De miniminivåer på fordonsskatter som anges i direktivet är mycket låga och saknar relevans för nordiska förhållanden.

Med "vägavgift" avses i direktivet en avgift eller skatt som tas ut för att ett fordon ska fă utnyttja den avgiftsbelagda infrastrukturen under en viss tid (t ex ett

6 (KOM (2002) 410 slutlig) 7 (KOM (2005)261 slutlig) 8 Om det införs ett lagstadgat krav om en viss inblandning av t ex etanol eller RME, tillåts inga skatteundantag. dygn, en vecka, ett år). Med "vägtull" avses en avgift eller skatt som tas ut för att fordonet ska få köra en viss sträcka.

Sverige, Danmark och Benelux-länderna (formellt även Tyskland) upprätthåller 
9 För speciella projekt som t ex broar och tunnlar tillåts dock speciella avgifter utöver vägavgift/vägtull.

10 ldag 359 euro/1000 I för bensin resp 302 euro/1 oo I för diesel. gemensamt ett vägavgiftssystem som är reglerat i direktivet. För att tunga fordon ska få köra på det utpekade s k TEN-vägnätet (alla större vägar) i dessa länder, måste fordonens ägare betala antingen en årlig avgift på (beroende på fordonens vikt, antal axlar och miljöklassning) 797-2 233 euro eller en avgift på 11 euro per dygn för alla typer av fordon.

Direktivet öppnar emellertid även för en helt annan typ av avgift eller skatt, baserad på körsträcka, som i direktivet kallas "vägtull", men som normalt brukar kallas kilometerskatt. För denna avgift anger direktivet inga fastlagda nivåer, bara generella principer för hur hög den får vara och hur den får differentieras. Nivåerna på avgiften/skatten ska i princip helt styras av kostnaderna för att bygga och underhålla vägsystemet, men reglerna är så vida och diffusa att det är möjligt för staterna att t ex helt basera avgifterna på de beräknade externa marginalkostnaderna (kostnader för vägslitage, avgaser, buller och olyckor på grund av tillkommande trafik). De km-skatter/vägtullar som tillämpas i Tyskland, Österrike och Tjeckien är baserade på detta direktiv.

Det är inte tillåtet att samtidigt ta ut både vägtull och vägavgift ${ }^{9}$ - detta är förklaringen till att Tyskland måste lämna Eurovignett-samarbetet när man införde sin s k MAUT på de tyska motorvägarna. Så länge Sverige och Danmark omfattas av eurovignett-samarbetet kan dessa länder inte införa finansierande tullar på enskilda vägsträckor. Vägavgift/vägtull får däremot kombineras med t ex lokala trängselavgifter.

\section{Indirekta beskattningsregler}

Medlemsländer som vill stimulerande införande av t ex skärpta avgasregler innan de nya kraven blir obligatoriska har rätt att uppnå detta med hjälp av skatterabatter. Dessa skatterabatter får dock inte vara större än vad som motsvarar extrakostnaden för den tillkommande reningsutrustningen. Ett aktuellt exempel är de stimulanser för partikelfilter på lätta dieselfordon som flera EUländer tillämpar (opkræver) i avvaktan på att denna utrustning fr o m 2009 blir obligatorisk.

\section{Aktuella förslag till förändringar Energiskattedirektivet}

I mars 2007 föreslog EU-kommissionen att minimiskattenivåerna för bensin och diesel skulle höjas så att man 2014 skulle uppnå en miniminivå på 380 euro per 1000 I för både bensin och diesel..$^{10}$ Kommissionen hänvisade bl a till att nuvarande skillnader i beskattning mellan medlemsländerna leder till "fuel tourism”, dvs till att körvägarna för lastbilar och bussar påverkas så att körsträckorna ökar med bl a ökade koldioxidutsläpp som följd.

Förslaget innehåller också flera markeringar som skulle underlätta införande av km-skatter (eurovignett-direktivets "vägtullar"). Bl a utlovas ett regelverk för hur länderna kan återbetala en del av dieselskatten till fordon som omfattas av km-skatt. Vid EU-parlamentets behandling begärde man att viktgränsen för differentiering av dieselskatt mellan lätt och tung trafik skulle ändras från 7,5 ton till 3,5 ton, dvs samma viktgräns som eurovignettdirektivet baseras på. En sådan förändring skulle ytterligare underlätta införande av km-skatt. 
Parlamentet krävde också att regelverket för återbetalning av dieselskatt till fordon som omfattas av km-skatt ska finnas på plats senast sex månader efter att förändringarna av direktivet trätt i kraft.

\section{Eurovignettdirektivet}

Beträffande eurovignettdirektivet har kommissionen nyligen genomfört en offentlig konsultation kring ett förslag som skulle tydliggöra att medlemsstaterna även formellt kan basera åtminstone en del av sina km-skatter ("vägtullar") på de externa marginalkostnaderna. Kommissionen har utlovat ett förslag till $\mathrm{i}$ juni 2008. 


\section{DEL II: Beskatning af person- og varebiler i de enkelte nordiske lande}

DEL II: 1. Danmark tal i parentes henviser til kilder sidst i Danmarkskapitlet

\section{Målsætninger}

For trafikkens klimapåvirkning har Danmark dels langsigtede mål, som der ikke er valgt konkret metode til at nå, dels kortsigtede initiativer, som afspejler visse mål, hvis niveau dog ikke altid er nærmere præciseret.

Den danske regering ønsker med sin energipolitik, herunder for transportens energianvendelse, at bidrage til at begrænse påvirkningen af jordens klima (1). På lang sigt ønsker regeringen, at landet bliver uafhængigt af fossilt brændstof og alene bruger vedvarende energi. Miljøministeren har på en række møder i efteråret 2007 peget på år 2075 som målår. Regeringen sætter det mål i sin Energiplan 2007, at $30 \%$ af det danske energiforbrug i 2025 er fra vedvarende energi, så fossilt brændstof kommer til at stå for 70 \%.

Regeringen fastsatte i 2002 et "pejlemærke" (hvilket er mindre bindende end et "mål") om at reducere transportsektorens $\mathrm{CO}_{2}$-udslip med $25 \%$ i 2030 i forhold til 1988. I forhold til i dag, hvor niveauet ligger knap 40\% over 1988niveauet, betyder det en $48 \%$ reduktion frem mod 2030 .

Danmark har med diverse ændringer af afgifterne for bilkøb og det at eje bil søgt at påvirke bilisterne - med varierende konsekvens og effekt - til at vælge biltyper med relativt små $\mathrm{CO}_{2}$ - og partikelemissioner.

I 1999 og 2007 blev registreringsafgiften, som betales ved køb af bil, ændret for at fremme køb af biler med lavt energiforbrug. I 2006 og 2007 er afgifterne ændret for også at opnå reduceret udslip af partikler.

Også den halvårlige afgift for at eje biler er (for biler indregistreret fra 1. juli 1997) indrettet, så brændstof-forbrug og dermed $\mathrm{CO}_{2}$-udledning bestemmer afgiftens størrelse, f eks er den mest benzinforbrugende bil 35 gange så dyr i "grøn ejerafgift" som den mindst benzinforbrugende.

Regeringen skriver juni 2007 i debatoplæg om en strategi for bæredygtig udvikling, at den arbejder for, at $\mathrm{CO}_{2}$-udslippet fra nye biler reduceres fra i gennemsnit $161 \mathrm{~g}$ pr kørt kilometer (2006) til 120 g i 2012 og 100 g i 2020 (1). I energipolitisk aftale februar 2008 aftaler regeringen og partier i Folketinget, at brintbiler skal fritages for afgifter og elbiler skal have forlænget deres afgiftsfritagelse ud over 2012. Der skal bruges 35 mio. kr. på forsøg med elbiler og udarbejdes strategi for reduktion af $\mathrm{CO}_{2}$-udledning. Biobrændstof skal leve op til EU's kommende initiativer for bæredygtighed, og man ønsker at fremme plugin-hybridbiler ${ }^{11}$ i Danmark.

11 Biler, som har to motorer en el- og en forbrændingsmoto - og som kan lades op ved nettilslutning, f.eks. om natten 
12 kilde: Vejtransporten i tal og tekst 2007, De Danske

Bilimportører, sept 2007

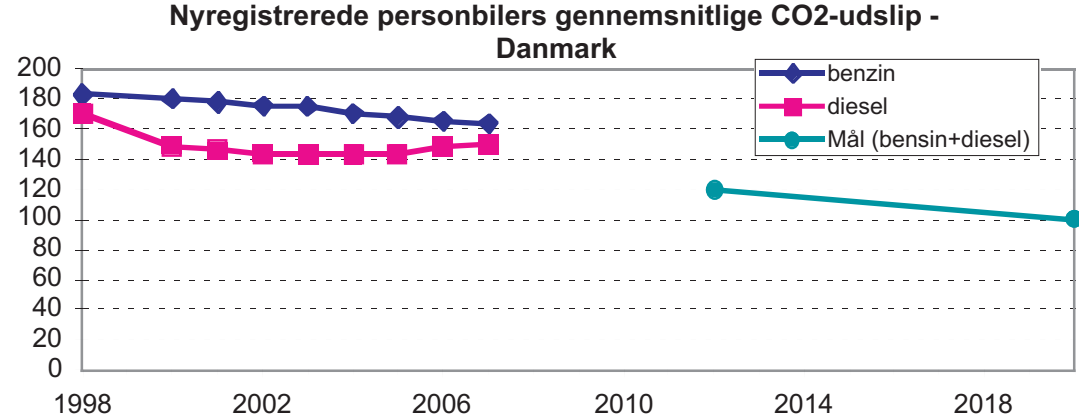

Figur 1: Nyregistrerede bilers gennemsnitlige $\mathrm{CO}_{2}$-udslip $\mathrm{g} / \mathrm{km}^{12}$

Regeringen har som mål at reducere kvælstofoxid $\left(\mathrm{NO}_{\mathrm{x}}\right)$ - og kulbrinte- $(\mathrm{CH})$ luftforureningen fra trafikken med $60 \%$ i 2010 i forhold til niveauet i 1988. Det er også regeringens mål at reducere partikelforureningen fra biler.

Regeringen søger at forøge andelen af biobrændstof i benzinen til $10 \%$ i 2020 (1). Dette bliver påvirket af ny EU-lovgivning, hvor man målsætter gennemsnitlig udledning på $130 \mathrm{~g} \mathrm{CO}_{2} / \mathrm{km}$ for nye biler suppleret med yderligere tiltag, der skal nedbringe $\mathrm{CO}_{2}$-emissionen med $10 \mathrm{~g} / \mathrm{km}$. EU og regeringen antager, at anvendelse af bioenergi i væsentligt omfang kan stå for dette. 
Tabel 3. Bilparken i

\section{Danmark ${ }^{13}$}

\begin{tabular}{|c|c|c|c|c|}
\hline Bilbestand i Danmark, 31.12.06 & I alt & $\begin{array}{l}\text { Pr. } 1000 \\
\text { indbygger }\end{array}$ & 31.12 .04 & \\
\hline $\begin{array}{l}\text { Personbiler } \\
\text { (privatejet + erhvervsbil) }\end{array}$ & 2.013 .899 & 369,7 & \multirow{4}{*}{$\begin{array}{l}\text { Private } \\
\text { I erhvervene } \\
\text { I alt }\end{array}$} & $\begin{array}{r}1.755 .425 \\
139.224\end{array}$ \\
\hline Varebiler $\quad 0-2.000 \mathrm{~kg}$ & 44.473 & 8,2 & & 52.805 \\
\hline $2.000-3.500 \mathrm{~kg}$ & 414.495 & 76,1 & & 336.004 \\
\hline I alt & 458.968 & 84,3 & & 388.809 \\
\hline
\end{tabular}

\begin{tabular}{l|l|lr}
\hline \multicolumn{1}{l|}{ Bilparks alder } & \multicolumn{2}{c}{ Andel over 10 år, 31.12.06: } & \multicolumn{2}{c}{ Gennemsnitlig alder: } \\
& Personbiler: $38 \%$ & Personbil $\quad 9,1$ år \\
& Varebiler: & $24 \%$ & \\
\hline
\end{tabular}

\begin{tabular}{|c|c|c|c|}
\hline \multicolumn{2}{|l|}{ Bilpark drivmiddel, 31.12.06 } & Antal & $\%$ \\
\hline \multirow[t]{5}{*}{ Personbiler: } & Benzin & 1.758 .286 & 87 \\
\hline & Diesel & 256.444 & 13 \\
\hline & $\mathrm{El}$ & 151 & 0 \\
\hline & Gas & 12 & 0 \\
\hline & I alt & 2.013 .893 & 100 \\
\hline \multirow[t]{5}{*}{ Varebiler: } & Benzin & $95 \cdot 563$ & 21 \\
\hline & Diesel & 363.345 & 79 \\
\hline & $\mathrm{El}$ & 35 & 0 \\
\hline & Gas & 18 & 0 \\
\hline & I alt & 458.961 & 100 \\
\hline
\end{tabular}

13 Kilde: "Vejtransporten i tal og tekst", 2007. (Militærets biler er ikke inkluderet) samt "Nøgletal for transport 2005", Transport- og energiministeriet + Danmarks Statistik.

Befolkning i Danmark 31.12.06: 5.447.00o. Varebiler: har vægt op til 3 tons fra og med 1995. Før da var grænse til lastbiler 3 tons.

\begin{tabular}{|c|c|c|}
\hline \multicolumn{3}{|l|}{ Årlig ændring af bilpark } \\
\hline \multirow[t]{3}{*}{ Nye biler pr år, ca. gennemsnit 2000-06 } & personbiler & 121.000 \\
\hline & varebiler $\star \star \star)$ & 41.000 \\
\hline & I alt & 162.000 \\
\hline \multirow[t]{3}{*}{ Ophugning pr år ca. } & personbiler & 97.000 \\
\hline & varebiler & 3.000 \\
\hline & I alt & 100.000 \\
\hline $\begin{array}{l}\text { Miljøbelastning, } \mathrm{CO}_{2} \text {, } \\
\text { alle nyregistrerede personbiler }\end{array}$ & \multicolumn{2}{|c|}{$\begin{array}{l}\text { 2000: } 180 \mathrm{~g} / \mathrm{km} \\
2006: 164 \mathrm{~g} / \mathrm{km}\end{array}$} \\
\hline
\end{tabular}


Figur 2.

Udvikling i gennemsnitlig egenvægt for personbiler ${ }^{14}$
14 Kilde: www.vejdirektoratet.dk 15 I dag hedder det DTU Transport

\section{Grundfakta om bilbestand, brændstofforbrug, miljøbelastning mv.}

Godt $7 \%$ af personbilparken i Danmark er "i erhvervene" (firmabiler), som i vidt omfang er undtaget for afgifter og beskatning. Der anvendes stærkt reducerede afgiftssatser bl.a. ved køb af gul-pladebiler. Varebiler under $3.500 \mathrm{~kg}$ udgør $18,5 \%$ af den samlede park af person- og varebiler.

Tabellen viser, at i 2004 udgjorde antal biler i erhvervene (firmabiler) 7,2 \% (139.224 biler) af alle person-biler i Danmark. I 2006 var andelen også 7,2 \%. Men i de årlige salgstal fra Danske Bilimportører er omkring $38 \%$ firmabiler. Dette hænger sammen med, at salgstallene i de senere år er øget, men endnu mere med, at firmabiler hurtigt (typisk efter 2-4 år) er afskrevet og sælges som privatbiler. Leasede biler udskiftes ligeså hurtigt. Dermed anskaffes reelt over 1/3 af den danske personbilpark som firma-biler, dvs. med så attraktive skattelettelser, at der i vidt omfang købes store, dyre og miljøbelastende biler.

\section{Vægt}

Gennemsnitlig egenvægt for nyregistrerede personbiler pr. halvår

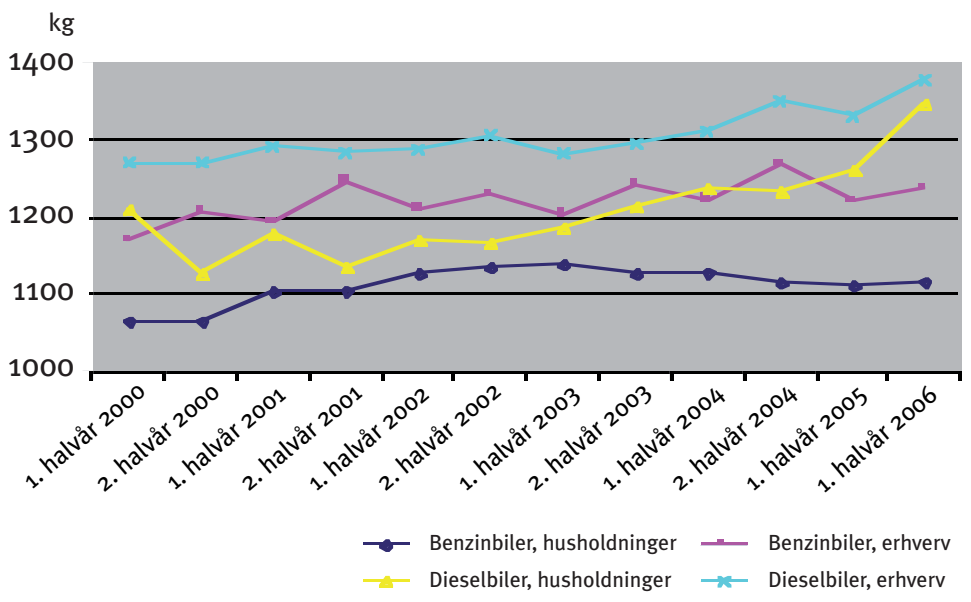

På de 6 år figur 1 beskriver, er alle bilkategorier blevet tungere, mest for dieselbiler (ca. $12 \%$ og $8 \%$ for henholdsvis husholdnings- og erhvervsbiler), og mindst for benzinbiler (ca. $4 \%$ og $5 \%$ for husholdnings- og erhvervsbiler). Det er stort set parallelle forløb. Men fra 2007 er der sket markante skift i forbindelse med ændret registreringsafgift, så der er kommet flere (især små) dieselpersonbiler. Diesel-4-hjulstrækkerne er næsten udgået i nybilsalget.

\section{Bilpark}

Transportarbejdet bestemmes af antal biler og kørsel pr bil. Den danske Infrastrukturkommission har fået udarbejdet prognoser baseret på forudsætning om, at der ikke sker regulering. For udviklingen i personbilparken $\mathrm{i}$ Danmark beskriver Danmarks Transportforskning (DTF) 2 scenarier, et højt og et lavt, jf. figur 3 og 4 samt tabel 4. DTF definerer varebiler som vogne med vægt 2-6 tons, dvs. inkl. en del lastbiler. 
Figur 3.

Udviklingen i bilparken 1966 til 2030, højt scenarium (millioner biler). Kilde: DTF 2007
Figur 3. Udviklingen i bilparken 1966 til 2030, højt scenarium (millioner biler). Kilde: DTF 2007

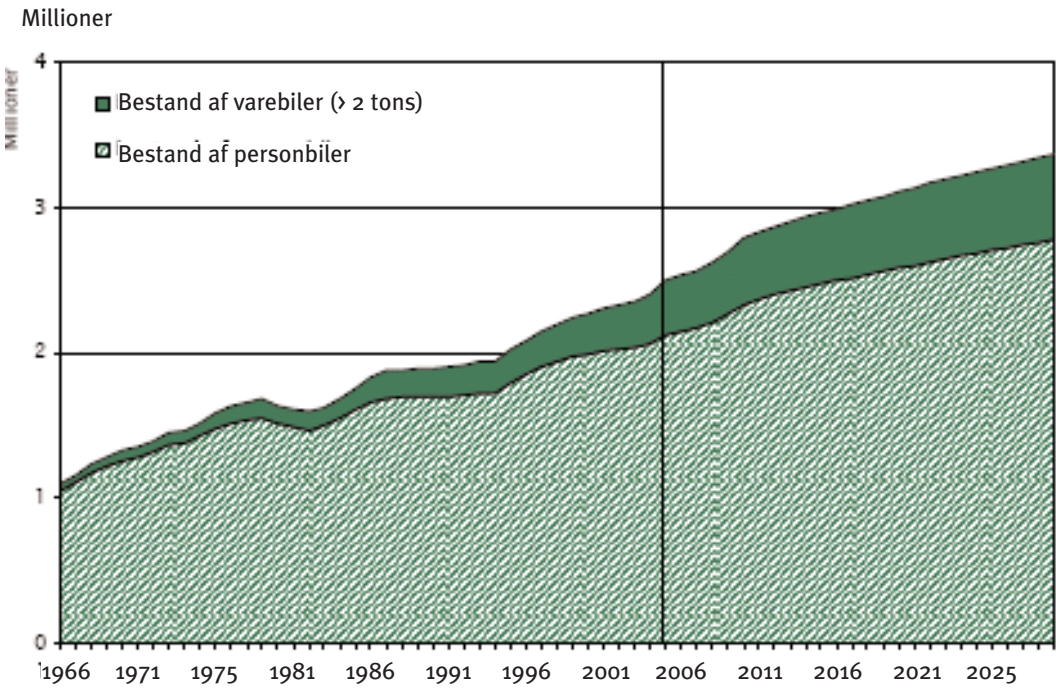

Figur 4. Udviklingen i bilparken 1966 til 2030, lavt scenarium (millioner biler). Kilde: DTF 2007

Millioner

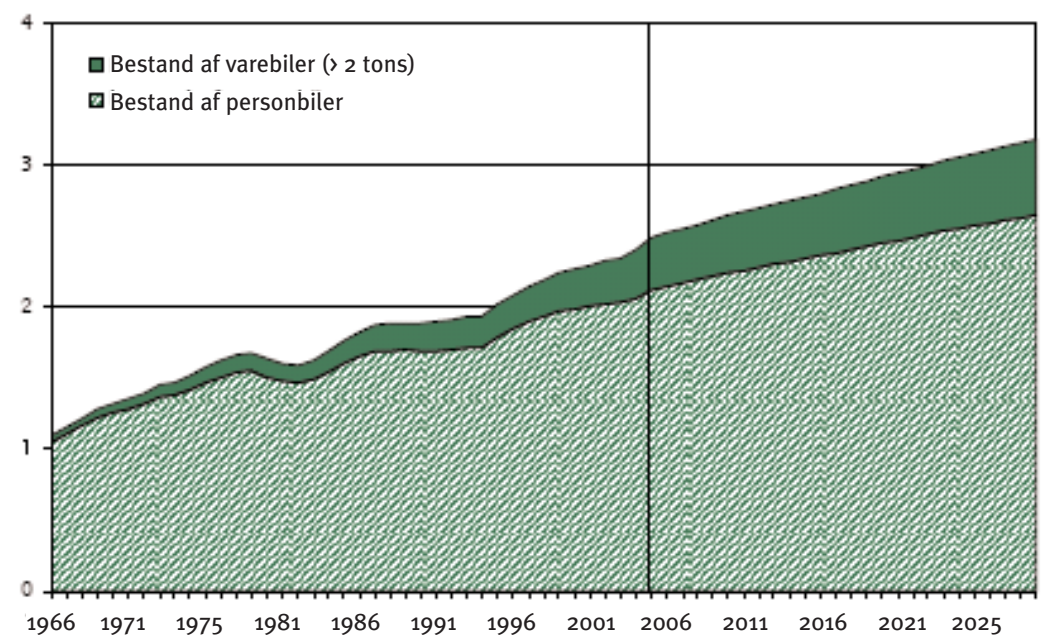


Tabel 2. Fremskrivning af bestanden af personbiler og varebiler

\begin{tabular}{lcrcr}
\hline & \multicolumn{2}{c}{ Højt scenarium } & \multicolumn{2}{c}{ Lavt scenarium } \\
& $\begin{array}{l}\text { Bestand } \\
\text { Ultimo }\end{array}$ & $\begin{array}{l}\text { Cns. } \\
\text { árlig vakst }\end{array}$ & $\begin{array}{l}\text { Bestand } \\
\text { ultimo }\end{array}$ & $\begin{array}{l}\text { Gns. } \\
\text { árlig vækst }\end{array}$ \\
\hline 1966 & 1.093 .303 & - & 1.093 .303 & \\
$1966-80$ & 1.636 .121 & $2,9 \%$ & 1.636 .121 & $2,9 \%$ \\
$1980-90$ & 1.887 .448 & $1,4 \%$ & 1.887 .448 & $1,4 \%$ \\
$1990-00$ & 2.268 .073 & $1,9 \%$ & 2.268 .073 & $1,9 \%$ \\
$2000-02$ & 2.328 .676 & $1,3 \%$ & 2.328 .676 & $1,3 \%$ \\
$2002-05$ & 2.494 .598 & $2,3 \%$ & 2.494 .598 & $2,3 \%$ \\
$2005-10$ & 2.786 .759 & $2,2 \%$ & 2.649 .762 & $1,2 \%$ \\
$2010-15$ & 2.966 .902 & $1,3 \%$ & 2.781 .880 & $1,0 \%$ \\
$2015-30$ & 3.367 .316 & $0,8 \%$ & 3.181 .929 & $0,9 \%$ \\
\hline
\end{tabular}

Tabel 4. Fremskrivning af bestand af person- og varebiler, Kilde DTF 2007

Et middelscenarie mellem de to yderpunkter indebærer, at bilparken vil udvikle sig som vist i tabel 5. Den årlige vækst i bilparken målt i antal ventes altså at blive af samme størrelsesorden som de foregående 40 år, og lidt mindre målt $i$ årlig vækstprocent.

\begin{tabular}{|c|c|c|c|c|}
\hline & Personbiler i Danmark & Vækst & $\%$ & Antal / år \\
\hline 1966 & 1.093 .303 & & & \\
\hline 2005 & 2.494 .598 & 1966-2005: & $+128 \%$ & 36.000 \\
\hline 2015 & 2.874 .391 & 2005-15: & $+15 \%$ & 38.000 \\
\hline 2030 & 3.274 .623 & 2015-30: & $+14 \%$ & 27.000 \\
\hline $2005-30$ & & 2005-30: & $+31,3 \%$ & 31.000 \\
\hline
\end{tabular}

Tabel 5. Antal personbiler i Danmark. ${ }^{16}$

De sidste 10 år er personbilparken i Danmark vokset med ca. 2,5 \% om året. Trafikministeriet har i sin Trafikredegørelse 2004 vurderet, at trafikkens $\mathrm{CO}_{2}$ emissioner vil stige med omkring $16 \%$ frem til 2020 og med $20 \%$ frem til 2030 set i forhold til 2005 , hvis der ikke foretages indgreb for at forhindre det. Efter dette er bilsalget øget markant (høje årlige salgstal). Kørselsomfanget er vokset "normalt".

\section{Trafikarbejde}

Infrastrukturkommissionen forudsiger en trafikvækst på 41-57 \% (lavt og højt scenarie) fra 2005 til 2030 på hele det danske vejnet (notat fra Danmarks Transportforskning). Heraf ventes de største procenter på de overordnede veje, idet kommissionen antager, at trafikken vil øges med $70 \%$ på det statslige vejnet. Disse prognoser er lagt til grund for en forslagspakke om infrastrukturudbygning af veje (og baner). Efter at kommissionens rapport blev offentliggjort $i$ januar 2008, har regeringen meddelt, at den i efteråret 2008 vil udsende dels en klimastrategi for transportområdet, dels en investeringsplan - og har hermed antydet, at dens investeringsplan ikke blot vil bygge på en fremskrivning af transportarbejdet, sådan som Infrastrukturkommissionens gjorde. 


\begin{tabular}{lcccc} 
& \multicolumn{2}{c}{ Højt scenarium } & \multicolumn{2}{c}{ Lavt scenarium } \\
& Årskørsel & Gns. årlig vakst & Årsørsel & Gns. årlig vakst \\
\hline 1970 & 15.368 & - & 15.368 & - \\
$1970-80$ & 14.199 & $-0,8 \%$ & 14.199 & $-0,8 \%$ \\
$1980-90$ & 16.696 & $1,6 \%$ & 16.696 & $1,6 \%$ \\
$1990-00$ & 16.766 & $0,0 \%$ & 16.766 & $0,0 \%$ \\
$2000-02$ & 16.325 & $-1,3 \%$ & 16.325 & $-1,3 \%$ \\
$2002-05$ & 16.660 & $0,7 \%$ & 16.660 & $0,7 \%$ \\
$2005-10$ & 17.969 & $1,5 \%$ & 16.934 & $0,3 \%$ \\
$2010-15$ & 18.770 & $0,9 \%$ & 17.415 & $0,6 \%$ \\
$2015-30$ & 19.982 & $0,4 \%$ & 18.726 & $0,5 \%$ \\
\hline
\end{tabular}

Tabel 6. Fremskrivning af årskørslen pr personbil (km pr år). Kilde DTF 2007

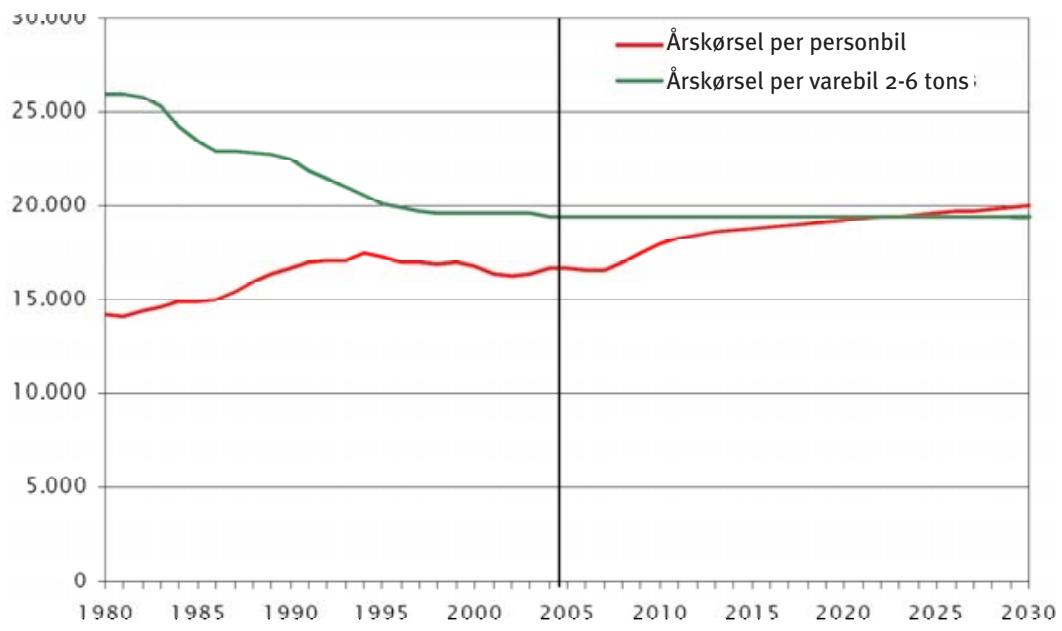

Figur 5 Årskørsel pr bil 1980-2030, person- og varebiler, højt scenarium, (km/år), DTF 2007

Fra 1980 til 2005 er personbiltallet $ø$ get med $52 \%$ i Danmark, mens trafikarbejdet er vokset med $72 \%$. Det at danskerne får væsentligt flere biler betyder altså ikke, at der køres mindre pr bil, tværtimod.

Kørsel pr personbil pr år ventes i gennemsnit øget med 12-19\% i de næste 25 år, mens det for varebiler og mindre lastbiler ventes stabiliseret fremover.

Den samlede trafik med personbiler og 2-6 tons-biler ventes at følges ad med en vækst på 41-57 \% i perioden 2005-30, jf. figur 6. Dette bygger altså dels på en vækst $i$ kørsel pr år pr personbil dels på en øgning af bilparken både for personbiler og 2-6 $\mathrm{t}$ biler, jf. figur 4 . 


\begin{tabular}{|c|c|c|c|c|}
\hline & \multicolumn{2}{|c|}{ Højt scenarium } & \multicolumn{2}{|c|}{ Lavt scenarium } \\
\hline & Trafikarbejde & Gns. årlig vækst & Trafikarbejde & Gns. årlig vækst \\
\hline 1980 & 24696 & - & 24696 & - \\
\hline $1980-90$ & 32651 & $2.8 \%$ & 32651 & $2,8 \%$ \\
\hline $1990-00$ & 38804 & $1,7 \%$ & 38804 & $1,7 \%$ \\
\hline $2000 \cdot 05$ & 42605 & $1,9 \%$ & 42605 & $1,9 \%$ \\
\hline $2005-10$ & 50746 & $3,6 \%$ & 45889 & $1,5 \%$ \\
\hline $2010 \cdot 15$ & 56016 & $2,0 \%$ & 49330 & $1,5 \%$ \\
\hline $2015 \cdot 30$ & 66966 & $1.2 \%$ & 59960 & $1.3 \%$ \\
\hline
\end{tabular}

Tabel 7. Fremskrivning af trafikarbejdet med person- og varebiler (mis km pr år). Kilde DTF 2007

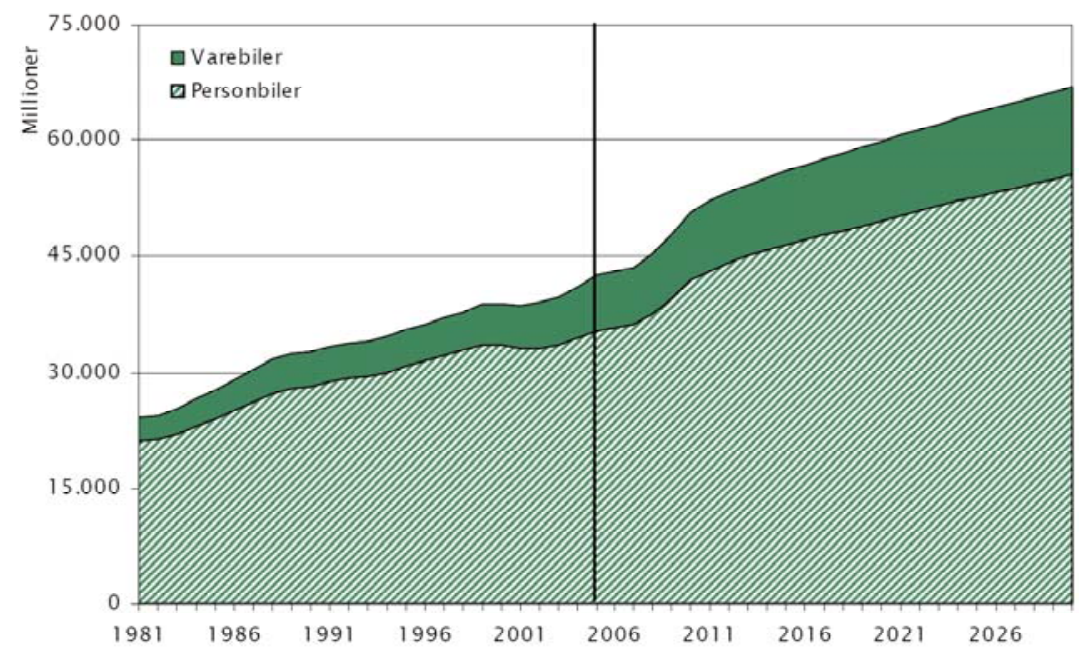

\section{Energiforbrug}

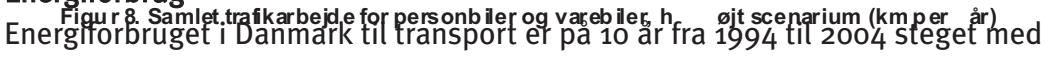
$8 \%$ for motorbenzin og med $28 \%$ for dieselolie. Dieselolien omfatter både forbrug til person- og varebiler, busser, lastvogne mv. Nederste kurve i figur 7 er derfor ikke kun udtryk for dieselperson og -varebilers forbrug, men tendensen er alligevel, at diesel vokser i andel mht. person- og varebiler, og at det samlede forbrug øges. 


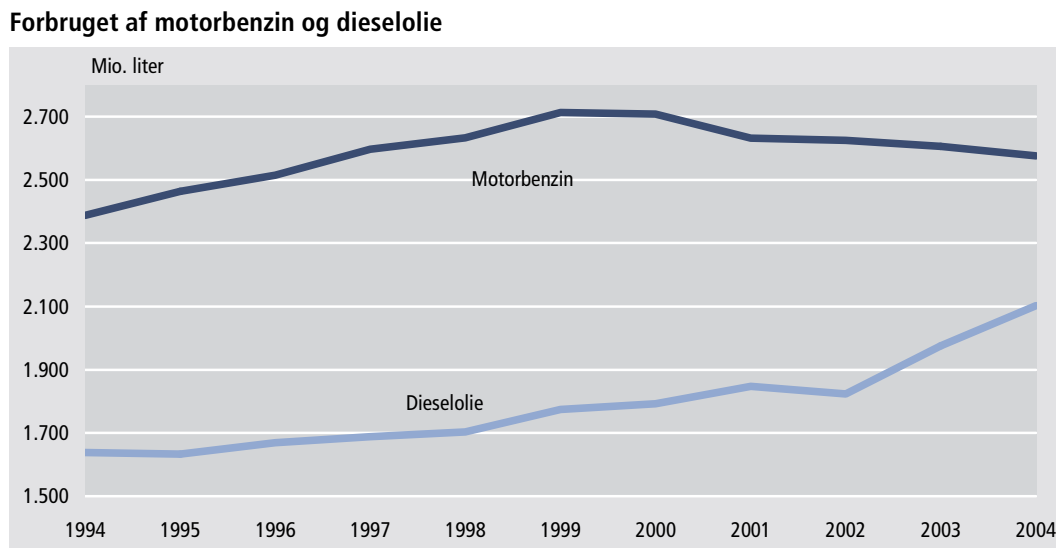

Figur 7. Forbrug i Danmark af motorbenzin og dieselolie 1994-2004. Kilde: Danmarks Statistik (3)

Tilsammen er energiforbruget (-anvendelsen) til vejtransport steget med $13 \%$ på 10 år, jf. tabel 8. Udviklingen afspejler mange modsatrettede tendenser: faldende energiforbrug pr bil i nye benzinbiler, men samtidig flere biler og i det lange historiske forløb mere kørsel pr bil. Og udviklingen mod tungere køretøjer modvirker bestræbelserne for at opnå energibesparelser i de enkelte biler. I de senere år er der sket en vis overflytning fra benzin- til dieselforbrug.

\begin{tabular}{|l|l|l|l|l|}
\hline & 1994 & 2002 & 2003 & 2004 \\
\hline Energiforbrug i PJ & 152,0 & 165,0 & 168,3 & 171,2 \\
\hline
\end{tabular}

Tabel 8. Vejtransportens samlede energiforbrug i Danmark 1994-2004 ${ }^{17}$

Sammenfattende har den historiske udvikling vist jævnt stigende antal biler, kørsel pr bil og vægt pr bil - dog med visse konjunkturmæssige udsving. Til gengæld er motorteknikken løbende forbedret, så resultatet alt i alt "kun" er blevet den omtalte vækst i energiforbrug til transport i Danmark på 13\% (1994-2004).

17 Kilde "Nøgletal for transport 2005", Transport- og energiministeriet og Danmarks Statistik
Det må også konstateres, at de senere årtiers udvikling med flere biler, som i gennemsnit kører længere, ventes (og planlægges, jf. Infrastrukturkommissionen ovenfor) at fortsætte de næste 25 år. 


\section{3-5. Indledning om beskatning og afgifter}

I Danmark betales der skatter og afgifter i forbindelse med person- og varebiler for:

Anskaffelse: Registreringsafgift, moms af forhandlerpris, men ikke af registreringsafgift

Eje af bil: Væatafgift / grøn ejerafgift, ansvarsforsikringsafgift, nummerpladegebyr, vejbenyttelsesafgift (kun for lastbiler på mindst 12 tons) mv.

Brug af bil: Benzin- og dieselafgift, moms både af forhandlerpris og andre afgifter

Bilejere betaler ved bilkøb registreringsafgift og moms (25\%) af værdi uden afgifter. Mens de ejer bilen betales grøn ejerafgift hvert halve år for biler købt efter 1.6.1997 eller vægtafgift (efter bilens vægt) for biler købt før dette tidspunkt, men ingen moms. Pr. 31.12.2006 var ca. 40\% af de danske personbiler fra før 1.6.1997.

Ved køb betales moms af forhandlerens pris, dvs. at der ikke er moms på registreringsafgiften. Derimod betales der moms af salgspris + øvrige afgifter ved $k ø b$ af benzin og diesel.

\begin{tabular}{rrrrrrrr}
$\begin{array}{l}\text { Mio. kr. } \\
\text { prar }\end{array}$ & $\begin{array}{l}\text { Registrerings- Vagtafgift/ } \\
\text { afgift }\end{array}$ & $\begin{array}{l}\text { Venzin- } \\
\text { grøn ejerafgift }\end{array}$ & $\begin{array}{l}\text { Ansvars-for- } \\
\text { afgift *) }\end{array}$ & $\begin{array}{l}\text { Anummer- } \\
\text { sikringsafgift }\end{array}$ & \multicolumn{2}{l}{$\begin{array}{l}\text { Vejbenyttel- } \\
\text { pladegebyr } \\
\text { sesafgift }\end{array}$} & I alt \\
\hline 2006 & 23.731 & 9.221 & 9.256 & 2.125 & 657 & 457 & 45.447 \\
\hline$\%$ & 52 & 20 & 20 & 5 & 2 & 1 & 100 \\
\hline
\end{tabular}

Tabel 9. Provenu (indtægt til staten) fra person-, vare- og lastbiler i Danmark, Kilde (2). ${ }^{18}$ Lastbiler, busser mv. kan ikke skilles fra i tabellen, og der kan heller ikke opdeles på person-og varebiler. *) Det er ifølge ministeriet ikke muligt at skille afgifter på diesel til vejtrafik fra visse andre afgifter. Så de er ikke med her. I ACEA-tax guide 2008 er der dog opgivet en samlet indtægt fra drivmidler og smøremidler på 14.956 mio. kr. pr år.

18 Kilde: "Vejtransporten i tekst og tal", Danske Bilimportører, sept 2007

19 totalvægt under 2,5 t: o kr. af de første $16.400 \mathrm{kr}$. (2008) og $50 \%$ af resten. For varebiler på 2,5-3,5 tons betales o $\mathrm{kr}$ af de første $34.000 \mathrm{krog} 30 \%$ af resten. Kilde: skatteministeriet
Momsen er af størrelsesorden 4,5 mia. kr. for benzin og diesel og 6 mia. kr. for bilkøb. Dermed er det samlede statslige provenu fra vejtrafikken af størrelsesordenen 56 mia. kr. om året (2006). Pr. køretøj er det samlede provenu eksklusiv moms i Danmark i gennemsnit 18.000 kr. pr år (inklusiv moms er det 22.000 kr.). Heraf kommer godt halvdelen fra køb af bil og kun $20 \%$ er brugsafhængig i form af benzinafgifter. Det kan på den baggrund forventes, at der er en vis træghed mod bilkøb i Danmark (få biler pr 1000 indbyggere). Til gengæld køres der relativt meget pr bil, dels fordi de færre biler så benyttes mere, dels fordi benzinen er forholdsvis billig i Danmark.

Gule plader (Varebiler). Biler kan indregistreres "på gule plader". Ejeren slipper så med $50 \%$ i registreringsafgift ${ }^{19}$. Til gengæld skal bilen have en varevognsudformning med plads til 2 personer og lastrum. Der har gennem årene været en 
del usikkerhed om konkret udformning og utilsigtet brug af gulpladebiler. Skattemyndighederne har dog strammet op med kontrol / bøder.

Biler indkøbt som firmabiler slipper i sidste ende for at betale moms både ved køb af bil og benzin. Hvis bilen bruges delvist til privat kørsel, skal der betales en tilsvarende andel moms. 


\section{Beskatning af drivmiddel}

I Danmark er der faste energi- og $\mathrm{CO}_{2}$-afgifter på benzin og autodiesel, dvs. at de er uafhængige af prissvingninger, men dog underlagt en årlig indeksering, som svarer til en pristalsregulering. Denne regulering af benzin- og dieselskat var - på linie med de øvrige bilskatter - afbrudt i perioden 2001-2007. Herefter blev den genoptaget, uden at man dog genoprettede den udhuling af afgifternes værdi, som var sket i mellemtiden.

Hertil kommer moms på $25 \%$ af produktionspris, avance samt øvrige afgifter. Resultatet ses i tabel 10.

\begin{tabular}{|c|c|c|c|c|}
\hline Kr. pr liter & $\begin{array}{l}\text { Benzin, } 95 \text { oktan, } \\
\text { blyfri med højst } \\
0,013 \mathrm{~g} / \mathrm{l} \text {, fra } \\
\text { benzinstation } \\
\text { med dampretur }\end{array}$ & $\%$ & Autodiesel & $\%$ \\
\hline Produktionspris, ca. & 3,53 & 33 & 4,65 & 44 \\
\hline Bruttoavance, ca. & 1,00 & 9 & 1,00 & 10 \\
\hline Energiafgift & 3,66 & 36 & 2,49 & 24 \\
\hline $\mathrm{CO}_{2}$-afgift & 0,22 & 2 & 0,25 & 2 \\
\hline Moms & 2,16 & 20 & 2,10 & 20 \\
\hline I alt & 10,79 & 100 & 10,49 & 100 \\
\hline
\end{tabular}

Tabel 10. Listepris på benzin og autodiesel fra Shell, 22. april 2008

Trods en højere produktionspris for autodiesel end for benzin er den samlede literpris normalt lavere for diesel end for benzin (f.eks. på dette tidspunkt $9 \%$ ), fordi afgifterne er mindst for diesel. Da biler kører længere pr liter på diesel end på benzin, er samfundets omkostninger til vejvedligehold mv. højere pr I diesel end $\mathrm{pr}$ I benzin. Afgiftssystemet fremmer derved $\mathrm{CO}_{2}$-reduktioner ved at fremme dieselbilsalg, men de øvrige eksternaliteter bør også inddrages i afgiftssystemet, men svarende til deres (mindre) betydning.

De - i forhold til salgsprisen - omkring $60 \%$ afgifter for benzin og $50 \%$ for diesel virker som en primitiv slags kørselsafgifter, idet de betales afhængig af kørslens omfang. Derimod skelnes der ikke mellem, hvad der køres i by og på land, i myldretid eller uden for myldretid eller på stærkt forurenede veje kontra ikke belastede eller ikke følsomme veje. Desuden viser analyserne i denne rapport, at der er sammenhæng mellem den samlede pris på drivmiddel og det samlede kørselsomfang.

Det har med mellemrum været diskuteret i Danmark, om man kunne have en højere benzin- eller dieselpris i forhold til Tyskland, uden at det gav væsentlige problemer med grænsehandel. En ældre dansk undersøgelse konkluderede: "at der må forventes en vis grænsehandel allerede ved afgiftsforhøjelser på en $\mathrm{kr}$./liter, men at denne grænsehandel dog er af begrænset omfang. ...at grænsehandlen ikke vil få et omfang der gør det meningsløst at benytte en forhøjelse af de danske benzinafgifter som et instrument i den trafikpolitiske 
regulering" ${ }^{20}$. De danske punktafgifter på benzin og diesel er betydeligt lavere end de tyske, men til gengæld er der tradition i Danmark for en højere avance på benzin og diesel, hvilket sammen med en højere moms gør, at udsalgsprisen er stort set den samme. Den store avanceforskel mellem Danmark og Tyskland er bl.a. blevet forklaret med, at det i Tyskland i modsætning til i Danmark i høj grad er indvandrere, der driver tankstationer.

Grænsehandelsproblemet er større for lastbiler end for personbiler, pga. lastbilernes større tankvolumen. Problemet for privatbiler kan dog også forstærkes af, at der er andre attraktive grænsehandels-objekter for danskere ved at køre til Tyskland, f.eks. øl.

\section{Afgiftsdifferentiering}

I 1990-erne indførtes en marginal afgiftsforskel mellem blyholdig og blyfri benzin. Resultatet blev, at bilisterne hurtigt begyndte at bruge blyfri benzin - dog for visse typer ældre biler først da ejerne fik anskaffet nye biler, hvis motorer kan køre på blyfri benzin. Dette viser en betydelig prisfølsomhed for variationer i benzinafgifterne, som da også er meget synlige og betales løbende efter forbrug.

Denne "succeshistorie", hvor en lille prisforskel udløste en stor adfærdsændring til et nært substitut, er ikke et stand-alone-tilfælde. Også tilfælde som udfasning af bl.a. svovl i diesel og dampopsamlingssystemer på benzinstandere kan nævnes. 


\section{Beskatning af køretøj}

\section{Registreringsafgift}

Registreringsafgift betales sammen med moms ved køb af bil.

\section{A. Personbiler}

Registreringsafgift betales som en éngangsafgift ved køb af bil. I løbet af de sidste 9 år er der indført en afhængighed dels af bilernes brændstofforbrug, dels af deres emissioner af partikler. Som udgangspunkt betales o \% for de første $8.600 \mathrm{kr}$., $105 \%$ af prisen fra $8.600 \mathrm{kr}$. til $74.000 \mathrm{kr}$. og $180 \%$ af resten af bilens værdi (forhandlerens salgspris).

Efter brændstofforbrug. Fra 01.01.2000 indførtes et nedslag i registreringsafgiften for særligt brændstoføkonomiske benzin- og dieselbiler. Men denne ændring gav kun lettelse for biler, som kørte mere end henholdsvis $25 \mathrm{~km} / \mathrm{l}$ (benzin) og $28 \mathrm{~km} / \mathrm{l}$ (diesel). Denne kaldes ofte Lupo-loven, da den især fik effekt for VW-Lupoen. Der skete en lettelse i 4 trin, men der kom ingen biler på markedet, som opfyldte trin 3 og 4 . Trin 1 gav $1 / 6$ reduktion til Smartcar, mens trin 2 gav $1 / 3$ reduktion til VW-Lupo samt en Audi-model. Derimod medførte disse kilometergrænser, at f.eks. Toyota Prius ikke fik nogen lettelse, da den kører 23,3 km/l - denne er derfor ikke slået an i Danmark.

I 2006 blev loven fulgt op med en tilsvarende regulering af brugtbilsafgifter ${ }^{21}$. Da de omfattede bilmodeller udgjorde få promille af nybilsalget, fik ændringerne i 2000 og 2006 kun marginal effekt på det gennemsnitlige CO2-udslip for nye biler i Danmark. Til gengæld viste loven sig effektiv til at fremme salget af især VW-Lupo. På et tidspunkt stod Danmark for $60 \%$ af salget af Lupo'er på verdensplan, fordi Danmark som det eneste land indførte en sådan afgiftsdifferentiering ${ }^{22}$.

Først i foråret 2007 indførtes en bred differentiering efter antal km/l, se tabel 11

\begin{tabular}{lll} 
Fra juni 2007 *) & $\begin{array}{l}\mathbf{1 0 0 0} \text { kr. ekstra afgift pr } \\
\text { km bilen kører } \\
\text { mindre end }\end{array}$ & $\begin{array}{l}\text { 4000 kr. reduceret } \\
\text { afgift pr km bilen kører } \\
\text { mere end }\end{array}$ \\
\hline Benzinbiler & $16 \mathrm{~km} / \mathrm{l}$ & $16 \mathrm{~km} / \mathrm{l}$ \\
\hline Dieselbiler & $18 \mathrm{~km} / \mathrm{l}$ & $18 \mathrm{~km} / \mathrm{l}$ \\
\hline
\end{tabular}

*) Gælder både person- og varebiler

Tabel 11. Knækpunkt for registreringsafgift og ændret afgift i forhold til knækpunkt.

I andre nordiske lande bruges liter pr $100 \mathrm{~km}$ i stedet for $\mathrm{km} /$ liter. $16 \mathrm{~km} / \mathrm{l}$ 6,25 liter $/ 100 \mathrm{~km}$

21 Oplyst af Joel Nielsen, Skatteministeriet, København, 1.7.08

22 Det lave salg på verdensplan førte til, at VW-fabrikkerne standsede produktionen af Lupoen omkring 2006.
Ændringen i 2007, hvor bl.a. dieselbiler med stort brændstofforbrug betaler større registreringsafgift, har hurtigt flyttet salget markant i retning af mindre dieselbiler, så nu næsten halvdelen af nybilsalget er dieselbiler, og ca. 40 \% er "småbiler". Udviklingen er markant selv om mekanismen ikke virker på den del af markedet, som er firmabiler (nu $38 \%$ af bilsalget), som alene beskattes efter pris og ikke påvirkes af tabel 11's regler. Der er dog også "mellemklassebiler", 
23 I en rapport, "Bilafgifter og energiforbrug", marts 2008, ved Tetraplan for Energistyrelsens forskningsprogram 2007, ses pa særligt energiøkonomiske biler og biler, der er ombygget til varebiler. Det konstateres, at reducerede bilafgifter for visse biltyper i høj grad har påvirket bilkøbernes valg af biltype og -model. Til gengæld har lempelserne ikke i sig selv haft væsentlig betydning for selve beslutningen om bilkøb. Omvendt konstateres det, at de relativt høje danske registreringsafgifter har generel betydning for det lave danske bilejerskab. Det analyseres, at de købte energiøkonomiske personbiler får trafikanterne til at køre 10-15\% længere, end de ellers ville have gjort. Netto spares der dog energi, idet disse biler kører dobbelt så langt på literen som almindelige biler.

Varebilskøberne kører ogsঃ længere end før bilkøbet. som kan køre mere end $16 \mathrm{~km} / \mathrm{t}$ på vej ind på markedet. Dieselbilkøberne vælger ikke i ret vidt omfang at købe biler med partikelfilter. Disse forskydninger viser stor påvirkelighed blandt bilkøberne for differentiering af registreringsafgifterne $^{23}$. Dette kan konstateres i Skatteministeriets notat " $Æ$ Endrede vægt- og registreringsafgifter giver bedre brændstoføkonomi” (http://www.skm.dk/publikationer/notater/6580.html.)

I 2007 blev "knækpunktet”, hvorover der skal betales 180 \% afgift, hævet, så alle hvidpladebiler ("privatbiler") blev 41.000 kr. billigere.

Sikkerhed. Derudover gives nedslag i registreringsafgiften for biler med:

Fradrag i afgiftspligtig værdi registreringsafgift

Pr airbag over 2 og højst 6

$1.280 \mathrm{kr}$.

ABS-bremser

$3.750 \mathrm{kr}$.

$1.000 \mathrm{kr}$.

$2.000 \mathrm{kr}$.

5 stjerner i EURO NCAP crash-test

ESP (elektronisk bremsestabilisering)

$2.500 \mathrm{kr}$.

Pr selealarm (maks. 3 alarmer)

$200 \mathrm{kr}$.

Omvendt forhøjes den afgiftspligtige værdi for personbiler med o og 1 airbag med 7.450 og $3.725 \mathrm{kr}$.

Partikeludslip. Fra 2006 og gældende til 2010 indførtes et nedslag i registreringsafgift på 7.200 kr. for både dieselperson- og dieselvarebiler med særlig lavt partikeludslip ( $\max 5 \mathrm{mg} / \mathrm{km}$ ), svarende til at der ikke skulle betales afgifter af påsatte partikelfiltre. Fra 2007 kom der et yderligere nedslag på 3.500 kr. svarende til, at det blev gratis at købe selve partikelfilteret.

B. Varebiler (gule nummerplader)

For varebiler (plads til 2-3 personer) betales ikke registreringsafgift af de første $16.400 \mathrm{kr}$. og $50 \%$ af resten for varebiler op til 2,5 tons. For varebiler over 2,5 tons betales o kr. af de første $34.000 \mathrm{kr}$. og $30 \%$ af resten. Denne ordning har baggrund i den generelle skatte- og afgiftspolitik over for virksomheder og er således ikke begrundet i energipolitiske hensyn. Ikke desto mindre har ordningen faktisk fungeret som en differentiering af købsafgiften, og i de senere år er mange personbiltyper ombygget, så de kan indregistreres som varebiler, og mange varebiler anvendes reelt som personbiler.

Der er store penge at spare, hvis en bil kan registreres som varevogn i stedet for som personbil. En bil til 150.000 kr. eksklusiv afgifter vil koste 214.000 kr. i registreringsafgift som personbil, men kun 40.800 kr. som varebil. De skattemæssige regler for varebiler er gunstige også for private, og 2000-06 er andelen af nyregistrerede varebiler til private (dvs. ikke erhverv) steget fra 11 til 25 $\%$.

Er varebilen på over 3 tons betales maksimalt $56.800 \mathrm{kr}$. i registreringsafgift. For kassevogne og pick-up'er betales dog ikke noget for de første $34.100 \mathrm{kr}$. og $30 \%$ i registreringsafgift af resten. 


\section{Hyrevogne (taxa)}

Der betales for en almindelig hyrevogn /taxa en afgift på $20 \%$ af den værdi, som ligger ud over 12.100 kr. Efter brug i 2 eller 3 år og 250.000 km eller $210.000 \mathrm{~km}$ kørsel kan hyrevognen omregistreres til personbil uden yderligere afgift. Der gives ikke fradrag eller tillæg for brændstofforbrug, men nedsættelse for lavt partikeludslip. Så den påvirkning af bilkøbene i retning af lille energiforbrug, som findes for almindelige personbiler, eksisterer ikke for taxa-biler.

D. Elbiler på maks. 2 t, biler til kørestolsbrugere mv. Disse køretøjer er fritaget for registreringsafgift foreløbig frem til 2012. DONG Energy planlægger sammen med Renault og Nissan at introducere "familie-elbiler" til under 100.000 kr. i Danmark fra 2011, med et udbygget net af opladningspunkter i landet. Bilerne vil kunne køre $160 \mathrm{~km}$. på en opladning. Tanken er at udnytte overskudsstrøm fra vindmøller om natten til formålet.

\section{Grøn ejerafgift / vægtafgift}

For biler indregistreret frem til 1997 betales i Danmark hvert år en vægtafgift, som afhænger af bilens vægt. Omkring 35\% af bilparken betaler i dag vægtafgift. Der er dermed en vis sammenhæng mellem energiforbrug og afgiftens størrelse, men motorens effektivitet, brændstoffets egenskaber mv. indgår ikke.

I 1997 indførtes for biler indregistreret efter dette tidspunkt i stedet en "grøn ejerafgift", som afhænger af bilens brændstofforbrug. Dermed er der direkte sammenhæng til energiforbruget og til dels til emissionsmængden. Den halvårlige grønne afgift pr bil fremgår af bilag 1 og varierer for

benzinbiler fra $260 \mathrm{kr}$. (minimum 32,1 km/l) til $9.230 \mathrm{kr}$. (under $4,5 \mathrm{~km} / \mathrm{l}$ ). dieselbiler fra $80 \mathrm{kr}$. (minimum $20 \mathrm{~km} / \mathrm{l}$ ) til $12.530 \mathrm{kr}$. (under 5,1 km).

Afgiften har en kraftig progression i forhold til vægt/brændstofforbrug. Men i årene efter 1997 er den danske bilparksgennemsnitlige vægt øget, jf. figur 1, hvoraf fremgår, at det gælder både benzin- og dieselbiler og både private og erhvervsbiler. På trods af progressionen synes beløbene at være for små til at påvirke trafikanterne synderligt i valget at biltype. Det er også bemærkelsesværdigt, at disse afgifter ikke knytter an til konkrete valg, som kan påvirkes af afgifternes størrelse. Der kunne tænkes at være en sammenhæng til beslutning om skrotning, idet ældre benzinslugere har højere afgifter end nye lettere biler. Men data tyder ikke på dette. Dette er vanskeligt at undersøge, da skrotning ofte hænger sammen med køb af ny bil, og bilsalget er ekstremt konjunkturfølsomt samt følsomt for registreringsafgiftens størrelse. Andre ordninger har haft større betydning - bl.a. gule nummerplader med tilhørende stor lettelse i registreringsafgift, som har skabt en radikal vækst i 4-hjulstrækkerbiler, jf. løbende statistik fra Danske bilimportører, da disse store biler, som samtidig fik en modemæssig succes, hermed blev bemærkelsesværdigt billige på trods af deres store vægt og dermed høje energiforbrug. Siden Folketinget i foråret 2007 gennemførte en differentiering af registreringsafgiften efter energiforbrug i dieselbiler er salget af 4-hjulstrækkere på diesel igen næsten udfaset. 


\section{5. Øvrige skatter og skattefradrag}

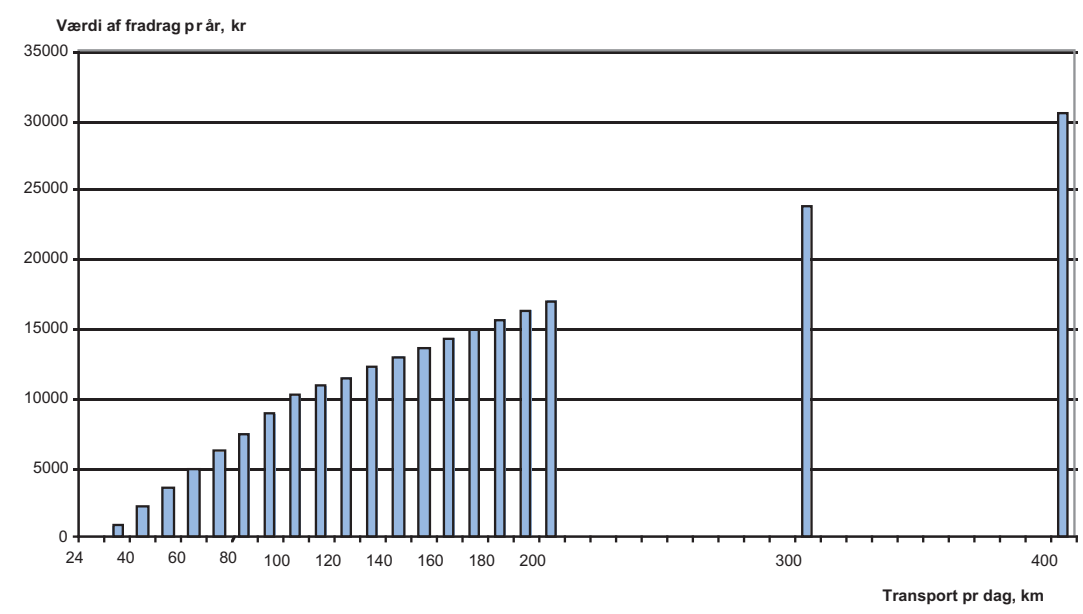

Figur: 8. Transportfradrag for kørsel mellem bolig og arbejde i Danmark, 2008.

Transport-skattefradrag for rejse mellem bolig og arbejdssted. I Danmark sidestilles alle transportformer på den måde, at alene afstanden bestemmer fradragets størrelse. Samkørsel i bil mellem f eks 3 personer udløser 3-dobbelt fradrag, hvad der rigeligt betaler udgifterne. Der er således et incitament til samkørsel. Derimod giver fradraget for kørsel mellem bolig og arbejdsplads ikke incitament til at bosætte sig tæt på arbejdspladsen. Incitamentet til at søge bus-tog-transport er ikke ret stort, fordi tilskuddet via skattefradrag er så stort også for bilkørsel, at udgiften har mindre betydning, og man derfor uden væsentlige netto-transportudgifter kan bosætte sig i stor afstand fra kollektiv transport. Boligpriserne skubber yderligere til denne mekanisme.

En afstand på $100 \mathrm{~km}$ (daglig kørsel på $200 \mathrm{~km}$ ) giver et skattemæssigt fradrag for 220 årlige arbejdsdage på: $220 X(75 \mathrm{~km} \mathrm{X} \mathrm{1,83} \mathrm{kr.} \mathrm{+} 100 \mathrm{~km} \mathrm{X} \mathrm{0,92} \mathrm{kr.)} \mathrm{=}$ $50.837 \mathrm{kr}$. Dette er et fradrag i dele af indkomsten ved beskatning. Den gennemsnitlige værdi er 33,5\% af transportfradraget. I dette eksempel $17.030 \mathrm{kr}$. Dette er et pænt tilskud til transportudgifterne, som den enkelte må veje sammen med ekstra brugt tid på transport, billigere husudgift mv.

For mange mennesker med forholdsvis langt til deres arbejde, er det meget billigt at transportere sig til og fra arbejde. Der ligger ganske vist visse styringshensigter i den fysiske planlægning (stationsnærhedsprincip, fingerbyudbygning, zonelovgivning mv.) i retning af at søge at få bopæl og arbejde til at ligge nær hinanden, men pendlingsafstandene øges jævnt fra årti til årti, idet transportmuligheder og økonomi muliggør dette. Arbejdsgivere kan tiltrække arbejdskraft over meget lange afstande, selv om der er kvalificeret arbejdskraft tættere på. Omvendt kan man bosætte sig i områder med stor herlighedsværdi og søge arbejde uafhængigt af bopælen uden synderlige økonomiske konsekvenser. Men det betyder en væsentlig miljømæssig belastning. Der fratrækkes cirka 10 mia. kr. om året i befordringsfradrag. I Danmark ydes der ikke, som i 
Sverige ekstra tilskud til bilkørsel, idet bilkørsel og kollektiv trafik sidestilles i Danmark. Men princippet om at reducere transportudgifter til lange pendlingsrejser er det samme.

"Ligningsloven" fastlægger fradrag i skatten for kørsel mellem bolig og arbejdsplads, idet der ikke gives fradrag for daglige afstande (frem og tilbage tilsammen) på o-24 km, 1,83 kr/km for $25-100 \mathrm{~km}, 0,92 \mathrm{kr} / \mathrm{km}$ for transport ud over $100 \mathrm{~km}$, og endelig $1,83 \mathrm{kr} / \mathrm{km}$ til visse udkantskommuner.

Firmabiler er biler stillet til rådighed for ansatte af firmaet. Stilles en firmabil til rådighed for en ansat til privat brug, beskattes denne fordel. Værdien sættes til de udgifter, den ansatte ville have haft ved at eje en privat bil. For firmabiler sker beskatningen i forhold til bilprisen og uafhængigt af forureningsomfanget. Ifølge Danske Bilimportører var $38 \%$ af de solgte biler i 2007 firmabiler.

"Fordelen" er, at firmaet kan trække udgiften fra i skatteregnskabet, så firma+ansat kun beskattes af den ansattes private brugsfordel, hvorimod en ansat, som selv købte bil og måske delvist stillede den til rådighed for firmaet, ville skulle tjene penge og betale skat svarende til hele bilens pris.

Staten opkræver 42,9 \% i afgift af ansvarsforsikringspræmien for motorkøretøjer. Forsikringen er lovpligtig. For et sæt normale nummerplader til en personbil betales $1.180 \mathrm{kr}$. i afgift. Siden år 2000 er der betalt et "miljøbidrag" for at eje en almindelig personbil. Der betales $90 \mathrm{kr} / \mathrm{a}$, og pengene bruges til udbetaling af en "godtgørelse", når en bil afleveres til skrotning. Der er således tale om en slags pant. Formålet er at sikre, at biler afleveres til forsvarlig skrotning.

Tilsvarende betales en afgift på 8 kr. for anskaffelse af nye (og brugte) dæk. Pengene bruges til miljømæssigt forsvarlig indsamling af kasserede dæk. De to sidste afgifter har direkte miljømæssig betydning i form af at sikre genanvendelse og forsvarlig affaldsbortskaffelse. De andre har kun den betydning, at det samlede afgiftstryk på det at anskaffe og eje bil er lidt højere og derfor marginalt kan påvirke forbrugsvalget.

Elbiler (som personbiler) er fritaget for registreringsafgift, de "grønne" løbende ejerafgifter er reducerede og i Københavns kommune betales ikke afgift for parkering for elbiler. Der er i dag meget få elbiler i Danmark.

Efter nogle år, hvor en del firmaer og institutioner af markedsføringsårsager havde enkelte elbiler, er det næsten gået helt i stå i Danmark. Men meget tyder på, at den teknologiske udvikling og afgiftssystemerne i dag rummer potentiale for store fremstød for elbiler i landet. 


\section{Hvordan styrer skatterne trafikkens miljøbelastning?}

I denne rapport er de centrale analyser koncentreret om at vurdere afgifter mv. på biltrafik og deres klimaeffekter i sammenligning mellem de nordiske lande. Her i statuskapitlet foretages dog nogle vurderinger af danske forhold alene. Ideelt bør vurderes, hvordan virkemidlerne fungerer i forhold til målene, herunder om de anvendte virkemidler er tilstrækkelige i forhold til målene. Ofte er det dog vanskeligt at vurdere, fordi mange forhold spiller sammen (lokalisering, beskæftigelse, konjunkturer.... - og afgifter).

Trafikudvikling. Som beskrevet side 20 forventes der i Danmark (Infrastrukturkommissionen) en trafikvækst på mellem $41 \%$ og 57 \% på landets veje fra 2005-30. Som regneeksempel kan der antages et middeltal på $49 \%$. Hvis det målsættes, at $\mathrm{CO}_{2}$-udslippet fra biltrafikken skal reduceres med $50 \% \mathrm{i}$ forhold til i dag svarende til regeringens målsætning, vil den gennemsnitlige bil i bilparken fra i dag til år 2030 skulle reducere sit $\mathrm{CO}_{2}$-udslip med $66 \%$ (indeks $100+49 \% \sim$ indeks 149 , reduktion til indeks 50 svarer til nedsættelse af $\mathrm{CO}_{2}$ udslip med $66 \%$ i forhold til 149). Det vil formentlig betyde, at de nye biler, der sælges fra omkring 2020, må have et $\mathrm{CO}_{2}$-udslip, der er $66 \%$ under niveauet for nybilsalget i dag. En $66 \%$ reduktion i $\mathrm{CO}_{2}$-udslip fra nye biler fra dagens niveau på $161 \mathrm{~g} / \mathrm{km}$ svarer til et niveau på $55 \mathrm{~g} / \mathrm{km}$. Dette er et stort (næppe realistisk) skridt, selv hvis det forudsættes, at en del af energien kommer fra vedvarende energi ( $\mathrm{CO}_{2}$-fri energi). Der må derfor tænkes i andre metoder end motorteknik også.

Benzin/dieselbiler og $\mathrm{CO}_{2}$ i nybilsalget. Der har gennem en årrække været en stigende dieselandel såvel for person- som varebiler. Dieselandelen blandt de solgte personbiler er fordoblet på 6 år. Dette hænger sammen med en modemæssig interesse for 4-hjulstrækkere samt afgiftsmæssigt gunstige vilkår for disse biler indtil sommer 2007, jf. tabel 64 og 65 samt løbende statistik fra Danske Bilimportører.

Og i de senere år er varebilernes andel af nybilsalget steget fra omkring $22 \%$ til omkring $29 \%$ i 2006 og i dag er andelen helt oppe på $38 \%$. Dette synes at være resultat af både udvikling i udbudet af køretøjer, af den teknologiske udvikling og af de ændringer, der er indført i afgifter for biltyperne. Først og fremmest får de betydeligt lavere afgifter på varebiler mange til at vælge dem, hvis de kan klare sig med 2-3 sæder. Det kan mange typisk for familiens bil nummer 2. Endringerne af bilafgifterne i sommeren 2007 har dog medført, at en større andel af bilsalget er mindre biler. Mange af disse er med dieselmotorer og hyppigt uden partikelfilter. 


\begin{tabular}{|c|c|c|c|c|c|c|c|c|c|}
\hline & 1998 & 2000 & 2001 & 2002 & 2003 & 2004 & 2005 & 2006 & 2007 \\
\hline Personbiler, i alt & & 112.695 & 96.187 & 111.598 & 96.076 & 121.484 & 146.914 & $154 \cdot 389$ & 156.098 \\
\hline - gns $\mathrm{CO}_{2}, \mathrm{~g} / \mathrm{km}$ & & 176 & 173 & 169 & 168 & 165 & 163 & 161 & 158 \\
\hline Dieselandel, \% & & 13,2 & 17,8 & 20,1 & 22,7 & 24,0 & 24,1 & 26,8 & \\
\hline - gns $\mathrm{CO}_{2}, \mathrm{~g} / \mathrm{km}$ & 170 & 149 & 146 & 144 & 143 & 143 & 144 & 148 & 150 \\
\hline Benzin, gns $\mathrm{CO}_{2}, \mathrm{~g} / \mathrm{km}$ & 183 & 180 & 178 & 176 & 175 & 171 & 168 & 166 & 164 \\
\hline Varebiler & & 31.484 & 31.003 & 31.444 & 31.870 & 44.730 & $55 \cdot 778$ & 62.780 & \\
\hline - Dieselandel, \% & & 83,9 & 83,7 & 87,5 & 86,5 & 86,6 & 87,8 & 90,6 & \\
\hline
\end{tabular}

Tabel 12: Nyregistrerede biler pr år og deres gennemsnitlige $\mathrm{CO}_{2}$-udslip, Kilde: (2). Brændstofnormer for dieselvarebiler er først indført fra 1.1 2008. Der findes ikke historiske tal for gennemsnitligt $\mathrm{CO}_{2}$-forbrug.

$\mathrm{CO}_{2}$-udslippet fra personbilerne er faldet med 2,5 g/km pr år på 6 år. Hvis gennemsnittet skal være $100 \mathrm{~g} / \mathrm{km}$ for biler solgt i år 2020, som det er regeringens mål, skal udslippet falde med 4,5 g/km pr år de næste 14 år.

For dieselpersonbilerne er der sket en vis forbedring i årene 2000-2003, men derefter er udslippet næsten vendt tilbage til niveauet i år 2000 pga.. voksende vægt blandt de solgte dieselpersonbiler. Det skyldes, at det er blandt de tungere dieselbiler, at salget er øget frem til 2006, samtidig med at produktionen af ekstremt brændstoføkonomiske biler (VW Lupo 3L og Audi A2 3L) er stoppet.

Påvirkning af forbrugsvalg. Det kan konstateres, at

- Registreringsafgiften er betydeligt adfærdspåvirkende. De relativt høje afgifter i Danmark må antages at være af betydning for, at der er et relativt lille bilhold (biler pr 1000 indbyggere i landet). Omlægningerne i 2007 i retning af billigere små, dieselbiler har flyttet salget betydeligt, bl.a. er salget diesel-"4-hjulstrækkere" på gule plader reduceret fra 1063 i januar 2007 til 174 i januar 2008.

- Drivmidlernes afgiftsstruktur ser også ud til at påvirke forbrugsvalget væsentligt. Bl.a. lykkedes det i løbet af kort tid at få stort set udfaset blybenzinen i Danmark med afgiftsdifferentiering som instrument.

- Vægtafgift / grøn ejerafgift synes ikke at påvirke bilkøb væsentligt. Den er uafhængig af brugsomfanget, og det må antages, at den heller ikke påvirker kørselsomfanget. Derimod kunne afgiften tænkes at påvirke udskiftningshastigheden for bilparken, idet ældre biler har større vægtafgift /grøn ejerafgift på grund af høje emissionstal. Men dette fænomen afspejler sig ikke i salgstallene. Bl.a. er det vanskeligt at se ændringer i forbrugsvalget i 1997 efter omlægningerne fra vægtafgifter til grønne ejerafgifter.

Se tabel 9 over provenu (statsindtægter) fra afgifter relateret til biler Det er derfor en overvejelse værd, om der ikke kan opnås en mere målrettet påvirkning af bilanskaffelse og -brug i Danmark, hvis ejerafgifterne omlægges til brugsafgifter i form af kilometerafgifter og kørselsafgifter differentieret efter køretøjets miljøstandard. Det sidste er bedst af hensyn til problemer med grænsehandel mv. Dette vil formentlig kunne forstærke incitamentet til udskift- 
ning af miljøbelastende, ældre biler. Derimod bør registreringsafgifterne fastholdes eller kun reduceres lidt, da de faktisk har en adfærdsændrende effekt.

Konklusioner om trafikanters påvirkelighed i miljømæssig sammenhæng af afgifter

Trafikanterne reagerer med justeret adfærd på afgifter, som har direkte sammenhæng med valg i købsøjeblikket:

- registreringsafgiftens niveau og struktur påvirker bilkøbene

- jf blandt andet diesel 4-hjulstrækkernes næsten forsvinden og de små dieselpersonbilers fremmarch i 2007 efter ændringer i registreringsafgifterne

- og jævnfør de relativt høje registreringsafgifter i Danmark og det relativt lille bilejerskab - drivmiddelafgift påvirker også (jf. blybenzinens forsvinden drevet ud af afgiftsændringer) og er "i famillie" med kørselsafgifter, jf. London og Stockholm, hvor kørselsmønster og -omfang i høj grad er påvirket og i overensstemmelse med målsætningerne.

Derimod er vægtafgiften/den grønne ejerafgift ikke forbundet med muligheder for umiddelbar ændring af adfærd, man må bare betale for den bil, man nu har. Så de påvirker ikke hverken bilkøb eller drivmiddelkøb væsentligt. Dog kan disse afgifter i teorien have betydning for, hvor hurtigt biler udskiftes, men praksis synes ikke at bekræfte denne hypotese.

Dog kan det overvejes at synliggøre de grønne ejerafgifter for bilkøberne, så de har lettere ved at overskue de samlede konsekvenser af deres køb. Handlingsforslag: omlæg vægt- og grønne afgifter til brugsafgifter koblet til den konkrete kørsel og afhængig af det brugte køretøjs miljøstandard (kilometerafgift, bompenge, kørselsafgift ...).

Måske bør registreringsafgifterne reduceres også, idet de delvist omlægges til løbende kørselsafhængige brugsafgifter. Total fjernelse er ikke fornuftigt. Det fører til væsentligt øget biltal, og man vil miste et incitament i købssituationen til at vælge en energiøkonomisk bil. En vis reduktion, men samtidig øget differentiering kan derimod komme på tale, jf. bl.a. de norske erfaringer med større progression.

I forbindelse med vedtagelsen af en samlet skatteomlægning for biler i 2007 vurderede regeringen $\mathrm{CO}_{2}$-effekterne af ændringerne. Effekterne for person- og varebiler skønnedes at blive ca. 2 \% årlig reduktion af CO2-udslippet, når effekten er slået helt igennem i år 2023. (1):

Skatteomlægning 2007 bestod overordnet af følgende dele:

- omlægning af varebilbeskatningen

- omlægning og styrkelse af fradragene for sikkerhedsudstyr

- indførelse af et fradrag eller et tillæg i registreringsafgiften for personbiler og varebiler afhængig af bilens brændstofforbrug, jf tabel 11

- En forhøjelse af skalaknækket for personbiler og autocampere.

Pakken skønnes samlet at reducere emissionerne fra vare- og personbiler med ca. 175.000 tons $\mathrm{CO}_{2}$ årligt på sigt svarende til 2 procent, dvs. når hele bilparken er udskiftet. 
De $2 \%$ sparet $\mathrm{CO}_{2}$ kan sammenholdes med regeringens "pejlemærke" om at reducere transportsektorens $\mathrm{CO}_{2}$-udslip med $50 \%$ frem til 2030 .

\begin{tabular}{l|r|r|r|r}
\hline \multicolumn{1}{l}{$\begin{array}{l}\text { Energiforbrug til } \\
\text { vejtransport }\end{array}$} & 1994 & 2002 & 2003 & 2004 \\
\hline Motorbenzin, mio l Indeks & 2.387 & 2.625 & 2.606 & 2.576 \\
& 100 & 110 & 109 & 108 \\
\hline Benzindrevne personbiler, & & & & \\
antal & 1.534 .307 & 1.748 .911 & 1.736 .917 & 1.731 .048 \\
Indeks & 100 & 114 & 113 & 113 \\
\hline Dieselolie, mio / 1) & 1.638 & 1.863 & 1.976 & 2.103 \\
\hline
\end{tabular}

Tabel 13. Energiforbrug og antal biler i Danmark, Kilde: (3) har tilgængelige data for 1994.

1) Både til lastbiler og varevogne

En forsigtig vurdering af udviklingen i brug af motorbenzin og bestanden af benzinbiler i Danmark viser, at bestanden er vokset relativt mere end salget af benzin. Dette kan dels skyldes bedre brændstoføkonomi, dels mindre kørsel pr bil. Persontransportarbejdet med bil antages (Transportministeriet) at være steget med $3 \%$ fra 2002-04, samtidig med, at det samlede antal personbiler er steget med 1,3\% $\%^{24}$. Dette tyder på, at kørslen pr bil er vokset i disse år, og at bilerne er blevet lidt mere benzinøkonomiske. Dette må tages med forbehold. Transporten pr bil udvikler sig næppe helt i samme takt som bilsalget, idet den ud over konjunkturer - som bilsalget er afhængigt af - også afspejler udvikling i lokalisering, befolkning mv. Men den lange tidshorisont i tabel 14 udjævner disse udsvingninger.

\begin{tabular}{|c|c|c|c|c}
\hline \multicolumn{3}{|c}{ Personbiler, antal } & $\%$-ændring & \multicolumn{1}{c}{$\begin{array}{c}\text { Trafikarbejde } \\
\text { pr år, mio. km }\end{array}$} \\
\hline 1980 & 1.636 .121 & & 24.496 & \\
\hline 2005 & 2.494 .598 & +52 & 42.606 & +73 \\
\hline
\end{tabular}

Tabel 14. Personbiler og trafikarbejde i Danmark 1980-2005

Dieselolien bruges både af personbiler, busser og lastbiler, så det er endnu vanskeligere at sammenholde forbruget af dieselolie, kørselsomfang og vognpark. 


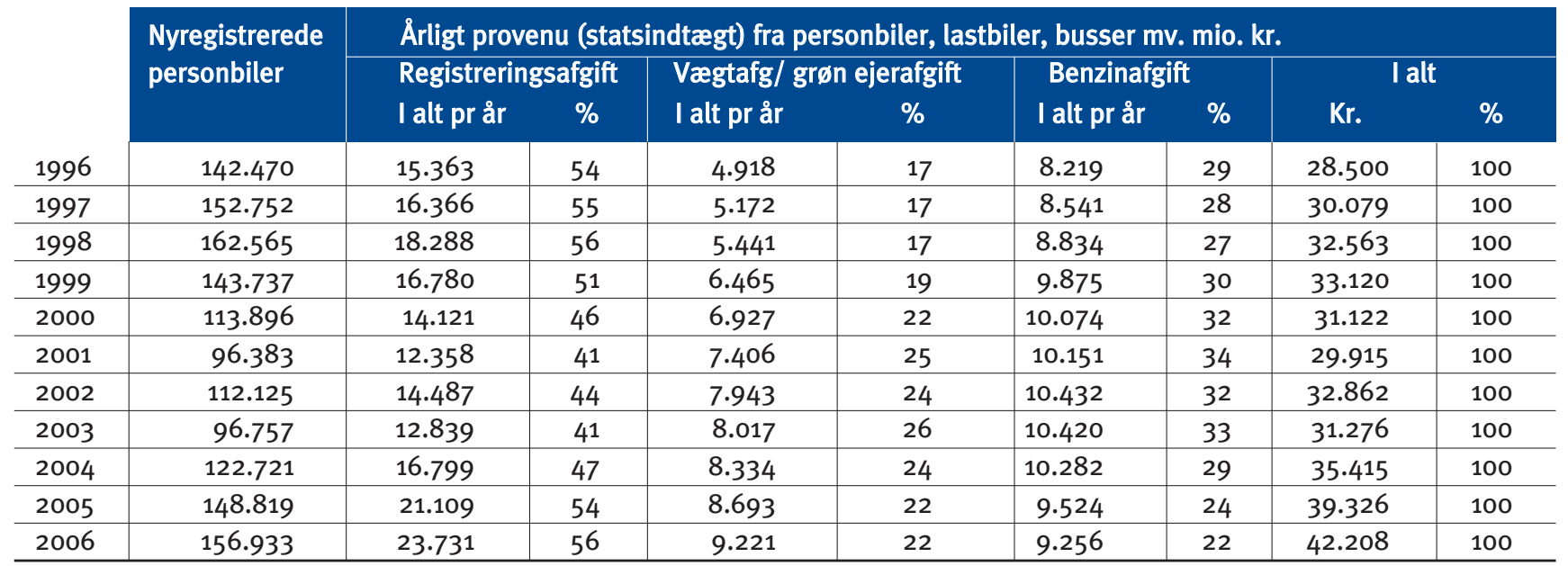

25 i Dansk Økonomi, forår 2006, en analyse af DK-trafikpolitik om bilbeskatning
Tabel 15. Udvikling i bilsalg og afgiftsprovenu til staten. Kilde: (2).

Skatteministeriet kan ikke udskille lastbiler fra afgiftsbeløbene, og benzinafgiften optræder alene, dvs. uden tilsvarende dieselafgift, fordi dieselafgift i statistikken optræder sammen med andre afgifter.

I Danmark fordeler bilafgifterne sig sådan, at der betales omkring 3/4 for at købe og eje bilerne og omkring $1 / 4$ for at køre i dem (de variable, forbrugsbestemte afgifter). Dette er i EU-sammenhæng en høj andel for køb og eje. Der har været en tendens til, at benzinafgifterne er blevet mindre både $\mathrm{i}$ andel og $\mathrm{i}$ værdi, hvis man tager hensyn til inflationen. Det kan derfor forventes, at der fortsat i EU-sammenhæng er relativt få biler i landet, men at bilisterne kører forholdsvis meget. Dette er også tilfældet.

Fra 1990 til 2007 er registreringsafgiften nedsat med godt 40.000 kr. på alle hvidpladebiler (personbiler), fordi "knækket", hvor der betales $105 \%$ under og $180 \%$ over, er løftet fra 19.700 kr. til 74.000 kr. Samtidig er bilerne dog blevet større og dyrere, så det samlede provenu (statsindtægt fra afgifter) er øget med godt $50 \%$ fra registreringsafgifterne.

\section{Forslag til reformer i Danmark}

På baggrund af forholdene i dag i Danmark er der følgende forslag til ændring af skatter og afgifter på person- og varebiler. Forslagene er baseret på status og analyser i dette arbejde og står for Det Økologiske Råds regning, men kan i $\emptyset$ vrigt i vidt omfang underbygges af analyser i Det Økonomiske Råds (vismændenes) analyser ${ }^{25}$. Med Kommissionens forslag til EU's klima- og energipakke, februar 2008, og med de relativt høje reduktionskrav, som tildeles Danmark i EU, er der et særligt behov for, at Danmark gør en indsats - og en relativt stor indsats. Skatter og afgifter er det vigtigste kendte virkemiddel, som i omfang og fordeling kan løse opgaven. 
1. Registreringsafgift - vægtafgift/grønne ejerafgifter - drivmiddelafgifter Registreringsafgifterne foreslås bevaret og ændret i endnu mere miljøfremmende retning, eventuelt kan de reduceres lidt totalt, men ikke meget jf. at "bilaccissen" i Sverige ikke havde nogen regulerende effekt. Det er næppe $\emptyset$ nskeligt med ret mange flere biler i Danmark, jf. den stadigt øgede kørsel pr bil og den øgede vækst i biltallet (figur s 11). Men en mindre afgiftsreduktion (f eks $30 \%$ af de samlede registreringsafgifter) og en samtidig indførelse af kørselsafgifter/road pricing og en væsentligt klarere differentiering efter bilernes emissioner og energiforbrug vil kunne føre til en miljømæssigt bedre bilpark. Men også andre samfundsmæssige omkostninger (øget vejslid og støj ved tungere biler) bør vægtes i taksterne for registreringsafgifter, $f$ eks må tungere, men mindre brændstofforbrugende dieselbiler også afgiftsbelægges efter de eksternaliteter (af mindre betydning), som kommer af længere og tungere kørsel pr liter diesel.

Vægtafgifter/grønne ejerafgifter i det omfang, som der i dag anvendes, har næppe nogen synderlig adfærdsregulerende betydning og bør omlægges til en direkte forbrugsafhængig afgift på kørte kilometer, differentierede kørselsafgifter (eller bompenge), parkeringsafgifter og i sidste ende road pricing, hvor miljøhensynet bedst kan gives vægt - eller for den sags skyld registreringsafgift. De nye afgifter må differentieres efter miljøkvalitet for køretøjet (både $\mathrm{CO}_{2}$ og andre emissioner). Det vil også give et incitament til at gamle, miljøbelastende biler udskiftes.

Drivmiddelafgifter bør foreløbigt bevares og øges i omfang (koordineret mellem flere nabolande) dels som opretning på et meget stort efterslæb, fordi afgifterne ikke er fulgt med de øvrige priser i samfundet i de senere årtier, dels for at lægge en dæmper på den løbende store stigning i kørselsomfanget (flere biler, mere kørsel pr bil). På et tidspunkt kan drivmiddelafgifterne integreres i et road pricing-system. Det skal ske koordineret med nabolandene for at undgå øget grænsehandel med brændstof.

Der bør gennemføres et nøjere studie af, hvad der i miljømæssig sammenhæng er den optimale balance mellem og udformning af de tre afgiftsformer. Omlægningen bør give en samlet øgning af provenuet fra biltrafikken, som i dag næppe betaler for sine samfundsmæssige omkostninger (jf. tidligere OECDundersøgelse). Men omlægningen kan også gennemføres provenuneutralt, men med en markant miljømæssig effekt.

2. Registreringsafgift, kort sigt

I 2007 indførtes en reduktion i registreringsafgiften på 4.000 kr. pr km en bil kører mere end $16 \mathrm{~km} / \mathrm{l}$ for benzinbiler og $18 \mathrm{~km} / \mathrm{l}$ for dieselbiler, og omvendt en øgning på $1.000 \mathrm{kr}$. pr km de kører mindre end de nævnte grænser, jf. tabel 11. Dette bør ændres, så tallet er $4.000 \mathrm{kr}$. pr km både ved mere og mindre kørsel pr l end henholdsvis 16 og $18 \mathrm{~km} / \mathrm{l}$.

3. Miljømæssigt ansvarligt mål for transportens samlede $\mathrm{CO}_{2}$-emissioner Som opfølgning på EU's klima- og energipakke, hvor "landbrug, trafik og individuel boligopvarmning" i Danmark frem til år 2020 skal reducere $\mathrm{CO}_{2}$ udslippet med $20 \%$, bør der foretages en samlet planlægning, hvor der udstikkes et "råderum" for trafikkens $\mathrm{CO}_{2}$-udslip. Det gælder i endnu høje- 
re grad, hvis de internationale klimaforhandlinger resulterer i skrappere krav end $20 \%$. Intet tyder på, at det kan undgås, at der skal ske reduktioner i trafikkens samlede $\mathrm{CO}_{2}$-emissioner. Der må derfor gøres op med den hidtidige praksis, hvor der forudsiges en trafikefterspørgsel uden hensyn til økonomisk, fysisk eller sundhedsmæssig realisme, og dernæst igangsættes infrastrukturudbygning, der på kort sigt søger at leve op til forudsigelserne. Det er netop denne tankegang, der prægede regeringens Infrastrukturkommissionen, som afgav betænkning i januar 2008.

4. Kørselsafgifter

Kørselsafgifter vil give et land et stort overskud, fjerne trængsel og reducere behov for infrastrukturudbygning til et realistisk niveau ${ }^{26}$.

Kørselsafgifter kan næppe undgås i fremtiden, hvor trængsel og miljøbelastning vil øges, hvis der ikke reguleres. Det kan politikerne lige så godt se i øjnene og starte på en fremsynet planlægning som led i en samlet skatteomlægning i landet, hvor skat på arbejde reduceres og lægges om til afgifter og skatter på forurening og brug af fossil energi. Skattekommissionen er en god anledning til at gøre noget ved det.

Der kan startes med trængselsafgifter (bompenge) i landets store byer samt en kilometerbaseret afgift, differentieret efter køretøjstype. På sigt er et landsomfattende road pricing-system det rigtige.

5. Elbiler

Regeringen har som mål at øge anvendelsen af vedvarende energi til 30 \% i 2025, mod $15 \%$ i dag, bl.a. med en kraftig udbygning af vindmølleparker. Der er brug for oplagring af el-energi. Det passer fint med, at elbiler kan aftage strøm bl.a. om natten. Samtidig er de lokalt helt forureningsfri og dermed en fordel for folkesundheden. Plug-in hybridbiler bør afgiftsslettes eller helt fritages. Der er behov for et storskalaforsøg og en offentlig satsning.

6. Biobrændsel

Afgifterne bør kun reduceres for biobrændsel-typer, som er bæredygtige i en livscyklusbetragtning, dvs. bl.a. bidrager med store $\mathrm{CO}_{2}$-reduktioner, $\mathrm{f}$ eks ved brug af 2. generations biobrændsel baseret på affaldsprodukter fra landbrug, skovbrug og fødevareindustri.

7. Firmabiler og fradrag for kørsel mellem bolig og arbejdsplads

Der bør ske en øget beskatning af firmabiler med differentiering for miljøbelastning. Derimod kan man hindre den sociale skævvridning og det $\emptyset$ gede kørselsomfang ofte med stærkt miljøbelastende køretøjer, som den nuværende lempelige beskatning medfører.

Der bør indføres incitament til at taxa-biler købes i udgaver med lille energiforbrug.

26 Jf. det engelske Eddington Transport Study
Fradrag for kørsel mellem bolig og arbejdsplads er en væsentlig årsag til den stadig voksende pendlingstrafik og det atomiserede lokaliseringsmønster for boliger og erhverv. "Regionsförstoring" som svenskerne kaldet det, er resultatet. Borgerne omsætter bedre transportmuligheder i længere 
transport og sparer ikke tid - miljøet er taberen. Det skattemæssige tilskud bør reduceres eller helt fjernes, specielt for længere ture.

\section{Kildeoversigt dansk statusafsnit:}

1. Grønt ansvar 2007 , regeringens debatoplæg om en strategi for bæredygtig udvikling, juni 2007

2. Vejtransporten i tal og tekst 2007, De Danske Bilimportører, sept. 2007

3. Nøgletal for transport 2005, Transport- og energiministeriet og Danmarks Statistik

4. Danmarks transportinfrastruktur 2030, Infrastrukturkommissionen, januar 2008

5. Langsigtet fremskrivning af vejtrafik, Danmarks TransportForskning, 2007

6. Energiinformation om nye danske personbiler, udvikling 1998-2006, Færdselsstyrelsen, aug. 2007

7. Bilafgifter og energiforbrug, Energimæssige effekter af afgiftslempelser for personbiler, marts 2008, Tetraplan for Energistyrelsens energiforskningsprogram 2007. 


\section{DEL II: 2. Norge}

\section{Målsætninger}

Utslippene av klimagasser i Norge var i 2006 på 53,6 millioner tonn $\mathrm{CO}_{2}$-ekvivalenter, ifølge Statistisk sentralbyrå (SSB). ${ }^{27}$ Av det sto transportvirksomheten for 17 millioner tonn, derav:

- veitrafikk (10,1 millioner tonn $\mathrm{CO}_{2}$-ekvivalenter)

- innenriks skipsfart og fiske (3,9 millioner tonn $\mathrm{CO}_{2}$-ekvivalenter)

- innenriks flytrafikk (1 million tonn $\mathrm{CO}_{2}$-ekvivalenter)

- noen mindre kilder

Utslippene fra veitrafikken har vært i sterk vekst siden 1990. I perioden 1990-2006 økte utslippene fra veitrafikken med hele 31 prosent, der godstrafikken står for størstedelen av veksten. Samtidig økte de samlede norske klimagassutslippene med rundt 8 prosent. Av de nasjonale utslippene sto veitrafikken for hele 19 prosent i 2006.

Ifølge prognoser forventes det videre en sterk vekst i $\mathrm{CO}_{2}$-utslippene fra landtransport og luftfart dersom ikke nye tiltak iverksettes. I regjeringens stortingsmelding, Norsk klimapolitikk fra juni 2007, framkommer det at det er ventet en vekst på nær 40 prosent i perioden 2005-2020. ${ }^{28}$

Den norske regjeringen har som mål å redusere utslippene av klimagasser fra veitrafikken med 2,5-4 mill tonn $\mathrm{CO}_{2}$-ekvivalenter innen 2020. Disse utslippsreduksjonene er i forhold til en antatt utslippsøkning fram mot 2020 på nesten 4 millioner tonn. ${ }^{29}$ Prognosene viser en vekst som er kraftigere enn eller omtrent like store som reduksjonene.

I januar 2008 kom alle partier på Stortinget unntatt Fremskrittspartiet til enighet om et klimaforlik. Klimaforliket innebærer at Norge har forpliktet seg til følgende:

27 http://www.ssb.no/klimagassn/

28 http://www.regjeringen.no/ $\mathrm{nb} / \mathrm{dep} / \mathrm{md} / \mathrm{dok} / \mathrm{regpubl} / \mathrm{stm}$ eld/2006-2007/Stmeld-nr34-2006-2007/10. $h$ tml?id $=473470$

29 http://www.regjeringen.no/ $\mathrm{nb} / \mathrm{dep} / \mathrm{md} /$ dok/regpubl/stm eld/2006-2007/Stmeld-nr34-2006-2007/10.html?id=473470

30 http://www.tu.no/natur/ article131421.ece

31 http://www.regjeringen.no /nn/dep/sd/Pressesenter/ Pressemeldingar/2007/ Nye-og-ambisiose-malom-reduksjon-avkli.html?id=487274
- Redusere utslippene av klimagasser med mellom 15 og 17 millioner tonn $\mathrm{CO}_{2}$-ekvivalenter innen 2020, hvor to tredeler av Norges totale kutt skal tas nasjonalt

- Norge skal bli karbonnøytralt samfunn i 2030

- Norge skal overoppfylle Kyoto-avtalen med 10 prosent

- Det skal legges fram et klimagassbudsjett i forbindelse med statsbudsjettene, som viser utslippsutviklingen og budsjettets klimakonsekvenser

- Avgiften på autodiesel og bensin går opp; Diesel økes med 10 øre literen, mens bensinavgiften går opp med $5 \emptyset \mathrm{re}^{30}$

I oktober 2007 kom Samferdselsdepartementet ut med følgende utsagn: "Regjeringa går inn for nye nasjonale mål om at gjennomsnittleg klimagassutslepp frå nye personbilar skal reduserast til maksimalt 120 gram $\mathrm{CO}_{2}$ per kilometer innan 2012. I dag er utsleppet frå nye bilar i gjennomsnitt $158 \mathrm{~g} / \mathrm{km} .{ }^{{ }^{11}}$ 


\section{Grundfakta om bilbestand, brændstofforbrug, miljøbe- lastning $\mathbf{m v}$}

Antallet av motorkjøretøyer i Norge har vokst dramatisk fra 1950 til 2006, slik som vist på figur 9 fra SSB. Personbilbestanden var på 2,1 millioner ved utgangen av 2006, eller rundt 71 prosent av alle motorkjøretøyer i Norge.

Varebilbestanden var da på $300000 .^{32}$ I tabell 1 er det også en oversikt over utviklingen av person- og varebilbestanden i Norge siden 1998 etter drivstoff type. Andelen dieseldrevne personbiler utgjorde 19 prosent av den totale personbilbestanden per 31. desember 2006. På figur 9 fra SSB er utviklingen av motorkjøretøybestanden i Norge vist grafisk fra 1950 til 2005. Fra figuren er det klart at det har vært en kontinuerlig økning hvert år.
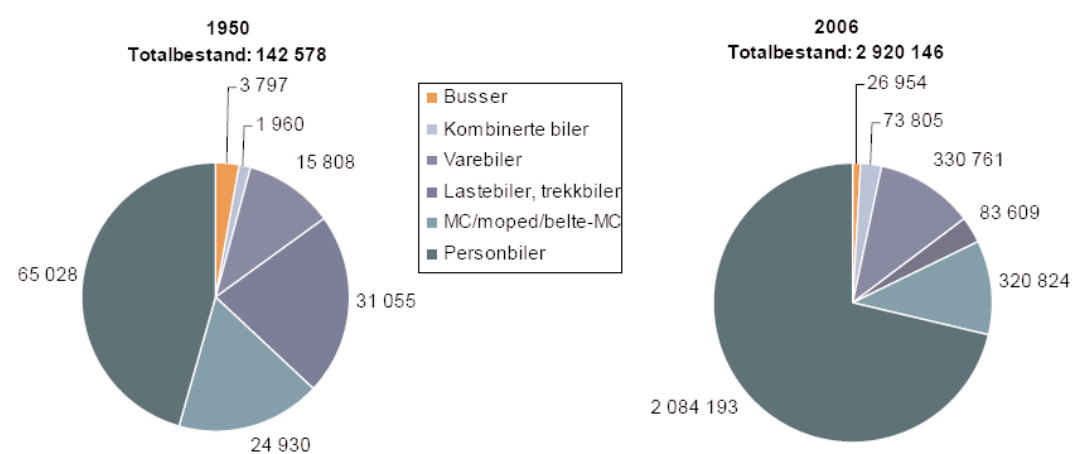

Figur 9. Registrert motorkjøretøyer per 31. desember 1950 og 2006, etter type. Kilde Brunvoll, F. mfl., Samferdsel og miljø, 2007, utgitt av Statistisk sentralbyrå.

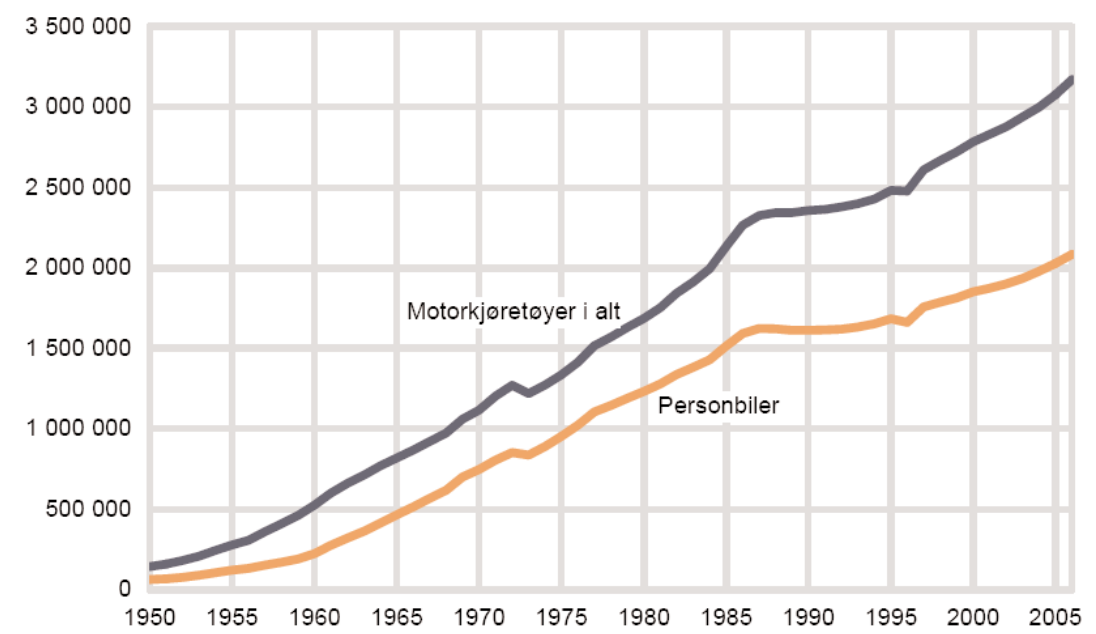

Figur 10. Antall registrert motorkjøretøyer i Norge per 31. desember 1950-2006. Kilde: Brunvoll, F. mfl., Samferdsel og miljø, 2007, utgitt av Statistisk sentralbyrå. 
På figur 11 framkommer utviklingen av førstegangsregistrerte personbiler i Norge de 11 siste årene. Fra figuren er det klart at det har vært en dramatisk $ø$ kning i kjøp av dieseldrevne personbiler de siste årene. I 2007 var antallet dieselbiler oppe i 50 prosent av alle førstegangsregistrerte personbiler. Denne utviklingen kan blant annet skyldes endring i engangsavgiften som diskuteres videre i senere kapitel.

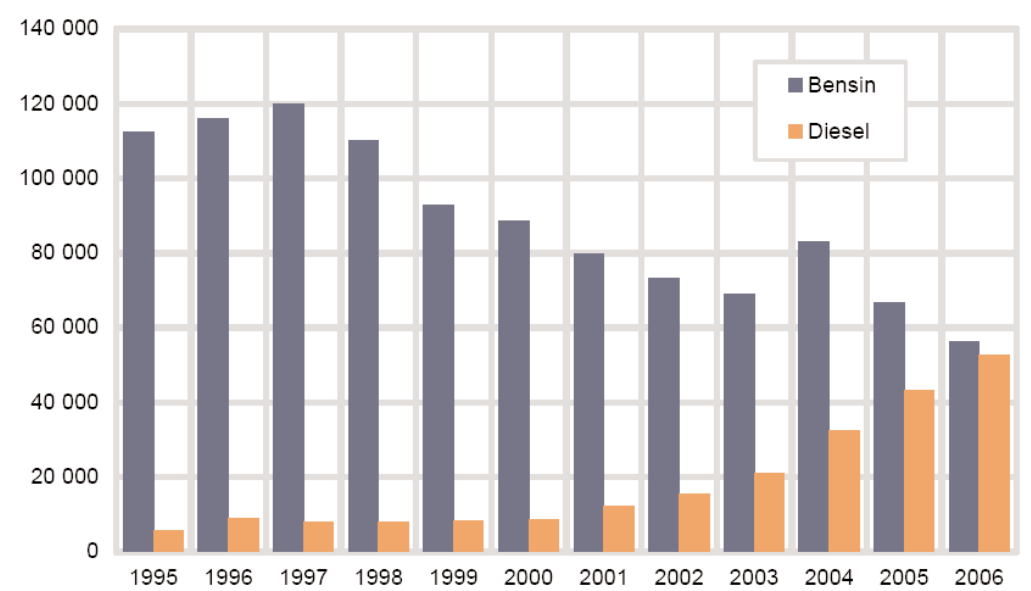

Figur 11. Antall førstegangsregistrerte personbiler etter drivstofftype, personbil i Norge 1995-2006. Kilde: Brunvoll, F. mfl., Samferdsel og miljø, 2007, utgitt av Statistisk sentralbyrå.

\begin{tabular}{|c|c|c|c|c|c|c|c|c|c|c|}
\hline $\begin{array}{l}\text { År/ } \\
\text { drivstoff } \\
\text { type }\end{array}$ & \multicolumn{2}{|c|}{1998} & \multicolumn{2}{|c|}{2000} & \multicolumn{2}{|c|}{2002} & \multicolumn{2}{|c|}{2004} & \multicolumn{2}{|c|}{2006} \\
\hline & Personbil & Varebil & Personbil & Varebil & Personbil & Varebil & Personbil & Varebil & Personbil & Varebil \\
\hline Bensin & 1669534 & 96430 & 1711829 & 94330 & 1719930 & 92976 & 1720220 & 85642 & 1688460 & 74909 \\
\hline Diesel & 112166 & 112016 & 134894 & 138279 & 177224 & 164929 & 254662 & 198137 & 386772 & 254869 \\
\hline
\end{tabular}

Tabell 16. Antall person og varebiler i Norge etter drivstofftype 1998-2006.

Kilde: Statistikkbanken, Statistisk sentralbyrå, www.ssb.no.

Andelen personbiler som går på alternativt drivstoff har økt de siste årene, men er fortsatt veldig beskjeden. I tabell 17 er det en oversikt over antall biler som gikk på alternativt drivstoff i Norge i 2006 og 2004. For biodiesel er det tale om en miks av ulike biodieseltyper.

\begin{tabular}{l|l|l} 
Drivstoff type & Antall i 2006 & Antall i 2004 \\
\hline El biler & 1500 (1400 personbiler) & 1193 \\
\hline Biodrivstoff & $\begin{array}{l}2250 \text { (Dieselbiler med } \\
\text { biodiesel innbl.) }\end{array}$ & - \\
\hline Hybrid & 55 (75 høst 2007) & 5 \\
\hline Gassdrevne biler & 176 (høst 2007) & - \\
\hline
\end{tabular}

33 http://www.ssb.no/emner/ 01/rapp_samferdsel_miljo/ra pp_200803/rapp_200803.pdf
Tabell 17: Antall biler som går på alternativt drivstoff i Norge, $20040 \mathrm{~g} 2006$. Kilde: Brunvoll, F. mfl., Samferdsel og miljø, 2007, utgitt av Statistisk sentralbyrå. ${ }^{33}$ 
34 http://www.ssb.no/bilreg/ 35 http://www.ssb.no/emner/ 01/rapp_samferdsel_miljo/ra pp_200803/rapp_200803.pdf 36 http://www.ofv.no/foreningssider/ofv_bilsalg.asp

37 http://www.toi.no/getfile. php/Publikasjoner/T\% D8I\% 2orapporter/2006/8442006/sam-844-2006-el.pdf

38 http://www.vegvesen.no/ ntp/transportanalyser/pdf/2 oo80117_sammrapp_grunnprog.pdf
Den norske bilparken er relativt gammel. Rundt 18 prosent av bilparken var over 15 år gammel i 2006. Ifølge SSB er gjennomsnittsalderen på registrerte biler i Norge 10,2 år for personbiler og 7,0 år for varebiler..$^{34}$ Ved utgangen av 2005 var bare 20 prosent av norskregistrerte personbiler nyere enn 5 år, mens 50 prosent var 10 år eller eldre. ${ }^{35}$ tabell 18 viser en oversikt over utviklingen av antall personbiler per 1000 innbyggere i Norge fra 2003 til 2006.

\begin{tabular}{lccc} 
Ar & $\begin{array}{l}\text { Antall personbiler } \\
\text { per 1000 innbygger }\end{array}$ & $\begin{array}{l}\text { Antall varebiler } \\
\text { per 1000 innbygger }\end{array}$ & $\begin{array}{l}\text { Person- og varebiler } \\
\text { per 1000 innb. i alt }\end{array}$ \\
\hline $\mathbf{2 0 0 0}$ & 414 & & \\
\hline $\mathbf{2 0 0 3}$ & 423 & 58 & 481 \\
\hline $\mathbf{2 0 0 4}$ & 429 & 62 & 491 \\
\hline $\mathbf{2 0 0 5}$ & & & 502 \\
\hline $\mathbf{2 0 0 6}$ & 445 & 71 & 516 \\
\hline
\end{tabular}

Tabell 18. Biler per 1000 innbygger i Norge per 31. desember i 2003--2006. Kilde Statistikkbanken, Statistisk sentralbyrå, www.ssb.no.

De mest populære bilene i Norge er Toyota og Volkswagen. Hittil i år ar andelen Volkswagen av alle personbilinnkjøp vært 15,5 prosent ifølge Opplysningsrådet for Veitrafikken. ${ }^{36}$

\section{Reisevaner og kjøreomfang i Norge}

Ifølge Transportøkonomisk institutt reiste folk i 2005 i gjennomsnitt 3,3 ganger om dagen, som er en økning fra 2001, da folk reiste i gjennomsnitt 3,1 ganger om dagen. Denne økningen kommer i hovedsak fra mer bilkjøring. Reiser med bil utgjør også rundt halvparten av reisene per dag, eller rundt 1,6 reiser. Gjennomsnittsreisen var da på 11,1 km, og samlet reiselengde per dag for hver person er da $37,4 \mathrm{~km}$. De fleste reisene er kortere reiser hvor 41 prosent er under 3 kilometer. Rundt en tredjedel er mellom 3 og $10 \mathrm{~km}$. Av alle reiser utgjør kollektive reiser kun 8 prosent. Av alle reiser er 19 prosent arbeidsreiser. (Kilde: Jon Martin Denstad, Øystein Engebretsen, Randi Hjorthol, Liva Vågane, 2006, Transportøkonomisk institutt, www.toi.no.) ${ }^{37}$ Folketallet i Norge var i 2005 på 4631800 .

\section{Trafikkutvikling og kjørselsomfang}

Ifølge prognoser fra arbeidet med Nasjonal transportplan (NTP) er det forventet at veksten i biltrafikken i Norge skal være som vist i tabell 19 fram mot 2040.

\begin{tabular}{l|l|c|c|c|c|c}
\hline & 2006 & $\mathbf{2 0 0 6}[\%]$ & 2006-2010 [\%] & 2010-2014 [\%] & 2014-2020 [\%] & 2020-2040 [\%] \\
\hline Bil & $\begin{array}{l}54600[\text { million } \\
\text { person km] }\end{array}$ & 1,7 & 1,3 & 0,9 & 0,7 & 0,9 \\
\hline $\begin{array}{l}\text { Lette } \\
\text { kjøretøy }\end{array}$ & $\begin{array}{l}35001[\text { million } \\
\text { kjørte kilometer] }\end{array}$ & 1,4 & 1,5 & 1,0 & 0,7 & 0,9 \\
\hline
\end{tabular}

Tabell 19. Innenlandsk persontransportarbeid. Nivå 2006 i mill. personkm (TØI-rapport 909/2007) 0 g prognose for årlig vekst. Kilde Nasjonal transportplan 2010-2019, 2008. ${ }^{38}$ 
39 http://www.nsb.no/ article24918-3418.html

40 http://www.mfm.no/db/5/ 2146.pdf
Gjennomsnittsbilen kjører rundt 13600 kilometer i året. Det ble kjørt 26197 personkilometer per personbil i 2006. Fram til 2020 er det ventet at veitrafikken skal øke med mer enn 20 prosent. ${ }^{39}$ Historisk har det vært en vekst i trafikken, slik som vist på figur 10 .

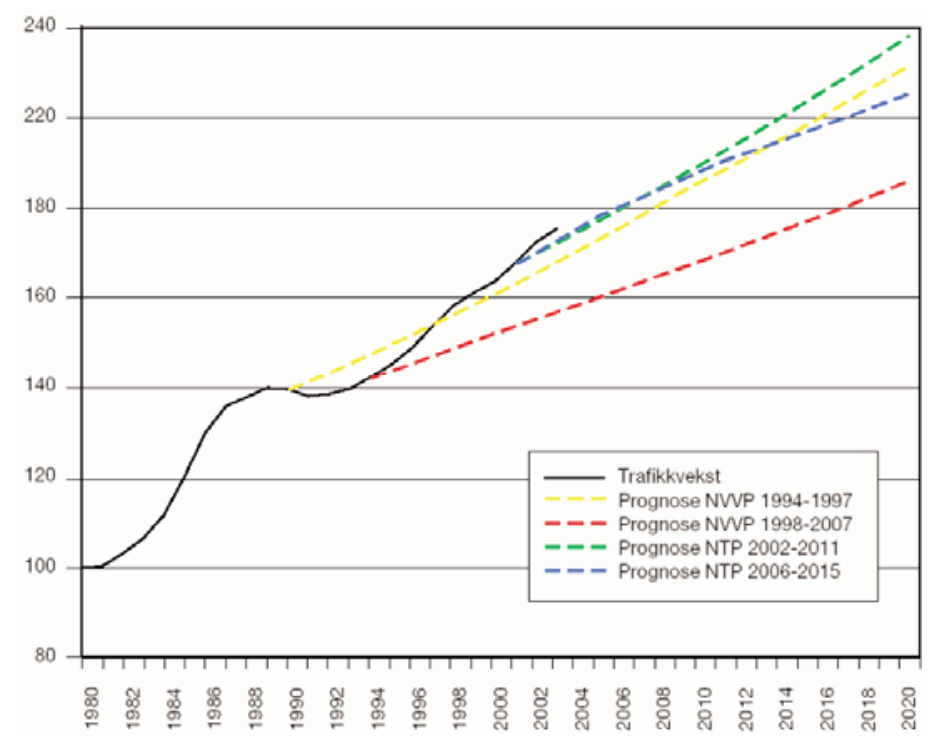

Figur 12. Trafikkutvikling og prognoser for vekst i utførte vognkilometer for gods- og persontrafikk 1980-2020 $1980=100$. Kilde: Odd I. Larsen og Jens Rekdal, Generelle og prosjektspesifikke trafikkprognoser. Sammenstilling av faktisk utvikling og ulike prognoser. ${ }^{40}$ 


\section{Beskatning af drivmiddel}

Tabell 20 viser en oversikt over utviklingen av drivstoff salg til veitrafikken de siste 11 årene. Fra tabellen kommer det fram at salget av autodiesel har økt kraftig de siste årene, noe på bekostning av utsalget av bensin.

\begin{tabular}{lrrrrrrr} 
& \multicolumn{7}{c}{ [millioner liter] } \\
& 1995 & 1997 & 1999 & 2001 & 2003 & 2005 & 2006 \\
\hline Bilbensin & 2159 & 2204 & 2196 & 2195 & 2157 & 2082 & 1997 \\
\hline Autodiesel & 985 & 1092 & 1192 & 1302 & 1415 & 1626 & 1766 \\
\hline
\end{tabular}

Tabell 20. Antall liter drivstoff solgt til veitrafikk i millioner. Kilde Statistikkbanken, Statistisk sentralbyrå, www.ssb.no.

Sitat fra SSBs rapport Samferdsel og miljø 2007: "Det ble solgt om lag 7,1 millioner liter biodiesel (o,5 prosent) i 2006, noe som er en fordobling fra året før. Rundt 3 prosent av all diesel som ble solgt i 2006, var blandet med biodiesel. Det blandes maksimum 5 prosent biodiesel inn i dieselen for at alle biler skal kunne tåle dette, og målt som ren biodiesel utgjorde det om lag 0,3 prosent av den totale dieselmengden. Det ble også solgt noe E85, dvs. bioetanol som blandes med 15 prosent bensin, men dette utgjorde bare noen promille av det totale bensinsalget." ${ }^{41}$

Forbruk av energi til veitrafikken var oppe i rundt 40 TWh i 2006. Det har aldri vært høyere og sto for 18 prosent av Norges totale energiforbruk i 2006, ifølge SSBs energiregnskap..$^{22}$

\section{Drivstoffforbruk}

I tabell 21 og i figur 13 er utviklingen av $\mathrm{CO}_{2}$-utslipp per kilometer for nye personbiler (bensin og diesel) i perioden 2001-2008 vist sammen med utviklingen i snitt for alle drivstoff. Fra figuren og tabellen kommer det klart fram at utslippene per kjørt kilometer har gått vesentlig ned siste årene, spesielt mye for bensinbiler. Det skyldes de nye $\mathrm{CO}_{2}$-differentierede engangsavgifter.

\begin{tabular}{lccc} 
Ar & [gram $\mathbf{C O}_{\mathbf{2}} /$ per $\mathbf{~ k m ]}$ & Snitt diesel \\
\hline 2001 & 183 & 186 & 168 \\
\hline 2002 & 180 & 183 & 170 \\
\hline 2003 & 180 & 182 & 174 \\
\hline 2004 & 180 & 183 & 174 \\
\hline 2005 & 175 & 180 & 169 \\
\hline 2006 & 177 & 181 & 173 \\
\hline 2007 & 159 & 161 & 158 \\
\hline 2008 & 158 & 159 & 158 \\
\hline
\end{tabular}

41 http:/www.ssb.no/emner/ 01/rapp_samferdsel_miljo/ra pp_200803/rapp_200803.pdf 42 http://www.ssb.no/emner/ 01/03/10/energiregn/
Tabell 21. Utviklingen fra 2001 til 2008 av CO2-utslipp per kilometer, i snitt og for nye bensin- og dieselbiler. Kilde: Opplysningskontoret for Veitrafikken. Tallene for 2008 gælder frem til 1. august. 


\section{$\mathrm{CO}_{2}$-utslipp per kilometer for drivstoff}

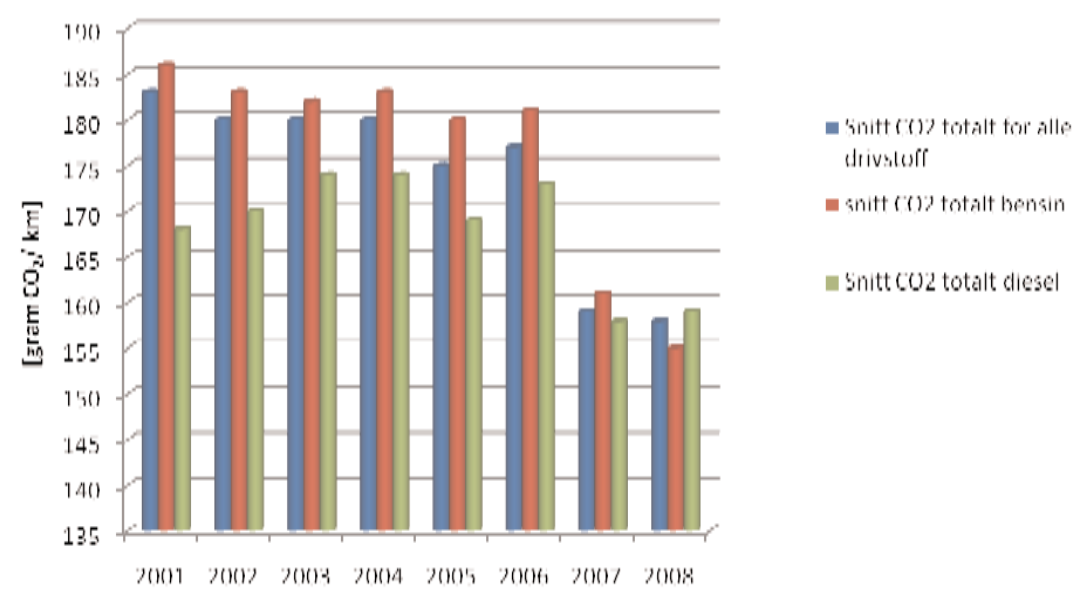

Figur 13. Utviklingen av C02-utslipp per kilometer for bensin, diesel og snitt for nye personbiler. Kilde: Opplysningsrådet for Veitrafikken.

Tabell 22 viser en oversikt over hvor mye $\mathrm{CO}_{2}$-utslipp forskjellige typer av kjøretøy forårsaker. Dieselkjøretøyer slipper ut mer $\mathrm{CO}_{2}$ totalt enn bensinbiler, men lastebiler står for en stor del av utslippet fra dieselkjøretøy.

$\mathrm{CO}_{2}$-utslipp i [Millioner tonn]

\begin{tabular}{ll} 
Veitrafikken totalt & 9,9 \\
\hline Bensinkjøretøyer & 4,5 \\
\hline Lette kjøretøy: bensin & 4,4 \\
\hline Tunge kjøretøy: bensin & 0,1 \\
\hline Dieselkjøretøyer & 5,3 \\
\hline Lette kjøretøy: diesel & 2,7 \\
\hline Tunge kjøretøy: diesel & 2,6 \\
\hline
\end{tabular}

Tabell 22. Utslipp av klimagasser fra veitrafikken i 2006. Kilde Statistisk sentralbyrå, www.ssb.no.43

Figur 13 viser en oversikt over alle de norske drivstoff avgiftene i budsjettet for 2008. Drivstoffavgiften har i dag til hensikt at forbrukeren av bensin er med å betale for de veiutbygging, ulykkes- og miljøkostnadene som bruk av bil medfører. $\mathrm{CO}_{2}$-avgiften skal reflektere klimakostnaden ved utslipp av klimagasser. Drivstoffavgiften på autodiesel avløste sammen med vektårsavgiften kilometeravgiften fra 1. oktober 1993. Avgiften pålegges mineralolje som brukes til motorkjøretøyer. Autodieselavgiften har den samme hensikten som drivstoffavgiften på bensin, det vil si å la forbrukeren betale for den samfunnsmessige kostnaden ved bilbruk. Avgiften innbetales av innenlandske produsenter og importører og legges på per liter omsatt autodiesel. Tabell 23 viser en oversikt

43 http://www.ssb.no/klimagassn/tab-2008-02-12o3.html over utviklingen av både drivstoff- og $\mathrm{CO}_{2}$-avgiften for både bensin og autodiesel. 


\begin{tabular}{lccrc} 
& \multicolumn{4}{c}{ [kr/liter] } \\
& 2004 & 2005 & 2007 & 2008 \\
\hline Drivstoff avgift Bensin & 3,96 & 4,03 & 4,17 & 4,28 \\
\hline Drivstoff avgift Autodiesel & 2,88 & 2,92 & 3,02 & 3,3 \\
\hline $\mathrm{CO}_{2}$-avgift bensin & 0,76 & 0,78 & - & 0,82 \\
\hline $\mathrm{CO}_{2}$-avgift autodiesel & 0,51 & 0,52 & - & 0,55 \\
\hline
\end{tabular}

Tabell 23 Oversikt over drivstoffavgifter fra 2004 til 2008 i Norge. Kilde Finansdepartementet.

\begin{tabular}{|c|c|c|}
\hline Type drivstoff & Drivstoffavgift & $\mathrm{CO}_{2}$-avgift \\
\hline Bensin & $\begin{array}{l}\text { Bensinavgift }(4,28 \mathrm{kr} / \mathrm{l} \text { for } \\
\text { svovelfri bensin og } 4,32 \mathrm{kr} / \mathrm{l} \text { for } \\
\text { lavsvovlet bensin) }\end{array}$ & $\mathrm{CO}_{2}$-avgift $(0,82 \mathrm{kr} / \mathrm{l})$ \\
\hline Bensin med innblandet etanol & $\begin{array}{l}\text { Bensinavgift }(4,28 \mathrm{kr} / \mathrm{l} \text { for } \\
\text { svovelfri bensin og } 4,32 \mathrm{kr} / \mathrm{l} \text { for } \mathrm{f} \\
\text { lavsvovlet bensin) }\end{array}$ & $\begin{array}{l}\mathrm{CO}_{2} \text {-avgift }(0,82 \mathrm{kr} / \mathrm{l}) \text {. Fritak } \\
\text { rfor andel etanol i bensin. }\end{array}$ \\
\hline $\begin{array}{l}\text { E85 ( } 85 \text { volumprosent etanol } \\
\text { og } 15 \text { volumprosent bensin) }\end{array}$ & Ingen & Ingen \\
\hline Autodiesel & $\begin{array}{l}\text { Autodieselavgift ( } 3,30 \mathrm{kr} / \mathrm{l} \text { for } \\
\text { svovelfri mineralolje og } 3,35 \\
\mathrm{kr} / \mathrm{l} \text { for lavsvovlet mineralolje) }\end{array}$ & $\mathrm{CO}_{2}$-avgift $(0,55 \mathrm{kr} / \mathrm{l})$ \\
\hline $\begin{array}{l}\text { Autodiesel med innblandet } \\
\text { biodiesel }\end{array}$ & $\begin{array}{l}\text { Autodieselavgift ( } 3,30 \mathrm{kr} / \mathrm{l} \text { for } \\
\text { svovelfri mineralolje og } 3,35 \\
\mathrm{kr} / \mathrm{l} \text { for lavsvovlet mineralolje). } \\
\text { Fritak for andel biodiesel i } \\
\text { mineralolje }\end{array}$ & $\begin{array}{l}\mathrm{CO}_{2} \text {-avgift }(0,55 \mathrm{kr} / \mathrm{l}) \text {. Fritak } \\
\text { for andel biodiesel } \mathrm{i} \\
\text { mineralolje }\end{array}$ \\
\hline Biodiesel & Ingen & Ingen \\
\hline Naturgass (CNG) & Ingen & Ingen \\
\hline Biogass & Ingen & Ingen \\
\hline Autogass (LPG) & Ingen & Ingen \\
\hline Hydrogen & Ingen & Ingen \\
\hline $\begin{array}{l}\text { Hytan (blanding av } \\
\text { hydrogen og naturgass) }\end{array}$ & Ingen & Ingen \\
\hline Elektrisitet & El-avgift $(10,50$ øre/kWh) & Ingen \\
\hline
\end{tabular}


45 http://www.regjeringen.no/ se/dep/fin/tema/andre/Sarav gifter/Dagens-gronne-skatter.html?id=439338

46 http://www.toll.no/templa tes_TAD/Article.aspx?id=120 534 \&epslanguage $=$ NO

47 http://www.toll.no/templa

tes_TAD/Article.aspx?id=120 534 \&epslanguage $=$ NO\#sOS bilo5

\section{Beskatning af køretøj}

De norske bilavgiftene deles i følgende kategorier:

- Årsavgift (betales hvert år)

- Omregistreringsavgift (betales ved salg av bilen)

- Engangsavgift (betales ved import av bilen og førstegangssalg)

- Vektavgift

Den totale inntekten staten fikk i 2007 fra disse avgiftene, var på NOK 28276 millioner. ${ }^{45}$

\section{Årsavgiften}

Ifølge Tollvesenet defineres årsavgiften slik: "Årsavgift skal svares for innenlandsregistrerte kjøretøy med tillatt totalvekt mindre enn $7500 \mathrm{~kg}$. Årsavgiften gjelder fra 1. januar til 31. desember. Det skrives ut årsavgift på alle avgiftspliktige kjøretøy som ifølge motorvognregisteret er registrert (har skilt på) pr. 1. januar eller som blir registrert i løpet av året. Eier av kjøretøyet, registrert enten ved salgsmelding eller omregistrering pr. 1. januar, er ansvarlig for at avgiften blir betalt det gjeldende året." ${ }^{46}$

Årsavgiften er en fiskal avgift som legges på forskjellige typer kjøretøy med tillatt totalvekt under $7500 \mathrm{~kg}$. Fleste kjøretøyer betaler den høyeste satsen som i 2007 var på 2915 kr. Campingtilhengere betaler 970 kr, og motorsykler betaler 1645 kr. Næringslivskjøretøy slik som drosjer, traktorer, mopeder og el-biler betaler en nedsatt årsavgift på kroner 370. Satsene for 2008 vises i tabell 24.

\begin{tabular}{|l|l|}
\hline Type kjøretøy & Sats i 2008 \\
\hline \hline $\begin{array}{l}\text { 1. Miljødifferensiert avgift } \\
\text { a) personbiler, varebiler, campingbiler, busser, kombinerte biler, } \\
\text { lastebiler, samt trekkbiler med tillatt totalwekt fra og med } 3500 \\
\mathrm{~kg} .\end{array}$ & 2660 kroner \\
b) dieseldrevne kjøretøy under nr. 1 bokstav a som ikke har \\
fabrikkmontert partikkelfilter.
\end{tabular}

Tabell 24. Årsavgiften for forskjellige typer kjøretøy i 2008. Kilde: Tollvesenet, http://www.toll.no/templates_TAD/Article.aspx?id=132299\&epslanguage $=$ NO

Fra og med 2008 er årsavgiften miljø differensiert og deles fra 1. januar $2008 \mathrm{i}$ to satser, med høy sats for dieselkjøretøy uten fabrikkmontert partikkelfilter og en lavere sats for kjøretøy som benytter annet drivstoff og dieseldrevne kjøretøy med fabrikkmontert partikkelfilter. ${ }^{47}$ 
48 http://www.toll.no/templa tes_TAD/CircularLetter.aspx? $d=120387$ \&epslanguage $=N$ 0

49 http://www.regjeringen.no/ $\mathrm{nb} / \mathrm{dep} /$ fin/dok/regpubl/stpr p/2007-2008/Stprp-nr-1 2007-2008$2 / 3 / 5 / 3 \cdot h t m l ? i d=483255$

\section{Engangsavgiften}

Fra 1. januar 2008 skal det i henhold til lov 19. juni 1959 nr. 2 om avgifter vedrørende motorkjøretøyer og båter betales avgift til statskassen:

1. ved første gangs registrering av motorvogner i det sentrale motorvognregisteret,

2. når betingelsene for avgiftsfrihet eller avgiftsnedsettelse ved første gangs registrering ikke lenger er oppfylt,

3. når en motorvogn som ikke tidligere er registrert her i landet urettmessig tas i bruk uten slik registrering,

4. når oppbygget motorvogn tas i bruk før ny registrering.

Stortinget fattet 28. november 2006 vedtak om ny engangsavgift for 2007 . Engangsavgiften har tidligere blitt beregnet på grunnlag av kjøretøyets egenvekt, effekt og slagvolum. Avgiftselementet basert på slagvolum ble etter 1. januar 2007 erstattes av et avgiftselement basert på CO2-utslipp for en del kjøretøy som blir registrert etter 1 . januar $2007 .{ }^{48} \mathrm{I}$ budsjettet for 2008 legges det opp til at avgiften for motoreffekten målt i kilowatt $(\mathrm{kW})$ endres slik at de svake bilene blir favorisert ved at de første $65 \mathrm{~kW}$ får en reduksjon i avgiften på 11,7 prosent. Avgiftsgrunnlaget for effekten som er mer enn $130 \mathrm{~kW}$, tilsvarende 176 hestekrefter, blir økt med 49 prosent. Satser for engangsavgiften i Norge fra 2002 til 2007 er vist i tabell 9. Biler som kan gå på etanol (flexifuel-biler) får nedsatt engangsavgiften med 10 000. Hybridbiler slik som Toyota Prius betaler 10 prosent mindre for egenvekten, fordi at den har to motorer. Varebiler betaler kun 22 prosent av den utregnede engangsavgiften.

$\mathrm{CO}_{2}$-komponenten i den endrete engangsavgiften er progressiv, dvs. at avgiften pr. gram $\mathrm{CO}_{2}$ som slippes ut, økes desto høyere $\mathrm{CO}_{2}$-utslipp et kjøretøy har. Dieselbiler har gjennomgående lavere $\mathrm{CO}_{2}$-utslipp enn bensinbiler, og omleggingen medførte derfor at avgiften for dieselbiler ble redusert i gjennomsnitt.Tall fra Opplysningsrådet for Veitrafikken (OFV) bekrefter at etterspørselen etter dieselbiler har økt etter at endringen ble innført. Ifølge OFV var andelen nye personbiler med dieseldrift om lag 74 prosent de første åtte månedene i 2007 mot 49 prosent i samme periode i 2006. Denne endringen har bidratt til at gjennomsnittlig spesifisert $\mathrm{CO}_{2}$-utslipp fra nye kjøretøy er redusert fra 170 $\mathrm{g} / \mathrm{km}$ i august 2006 til $160 \mathrm{~g} / \mathrm{km}$ i 2007. Den langsiktige effekten av endringen er det imidlertid for tidlig å si noe sikkert om. ${ }^{49}$

$\emptyset k t$ bruk av dieselbiler har imidlertid en ulempe i form av høyere utslipp av partikler og nitrogensoksider. Dette er en svakhet ved avgiftsendringene, som bør følges opp med tiltak som gir mindre lokal luftforurensing. 
50 Motorvogner som omfattes av plikten til å dokumentere drivstofforbruk og $\mathrm{CO}_{2}$-uts-

lipp etter forskrift 4. oktober 1994 nr. 918 om tekniske krav og godkjenning av kjøretøy, deler og utstyr (kjøretøyforskriften) kapittel 49, satser for flere typer kjøretøy: http://www.toll.no/tem plates_TAD/CircularLetter.as px?id $=120385$ \&epslangua$g e=N O$

51 http://www.toll.no/templates_TAD/CircularLetter.aspx?i $d=120385$ \&epslanguage $=N O$

52 http://www.toll.no/upload /dokumenter/avgiftsrund skriv/2002vektaarsavgift.pdf

\begin{tabular}{|c|c|c|c|c|c|}
\hline & 2002 & 2003 & 2004 & 2006 & $2007^{50}$ \\
\hline \multicolumn{6}{|l|}{ Engangsavgiften } \\
\hline første 1150 kg & 32,68 & 33,4 & 34,00 & 35,36 & 33,16 \\
\hline neste 250 kg & 65,36 & 66,8 & 68,00 & 70,72 & 72,27 \\
\hline neste 100 kg & 130,73 & 133,61 & 136,01 & 141,43 & 144,55 \\
\hline Resten 152,04 & 155,38 & 158,18 & 164,49 & 168,11 & \\
\hline \multicolumn{6}{|c|}{ Slagvolumavgift kr/cm3 } \\
\hline første $1200 \mathrm{~cm} 3$ & 9,65 & 9,86 & 10,04 & 10,44 & - \\
\hline neste $600 \mathrm{~cm} 3$ & 25,26 & 25,82 & 26,28 & 27,33 & - \\
\hline neste $400 \mathrm{~cm} 3$ & 59,42 & 60,73 & 61,82 & 64,29 & - \\
\hline Resten 74,23 & 75,86 & 77,23 & 80,31 & - & \\
\hline \multicolumn{6}{|c|}{ Motoreffektavgift kr/kW } \\
\hline første $65 \mathrm{~kW}$ & 129,23 & 129,01 & 131,33 & 136,57 & 120,59 \\
\hline neste $25 \mathrm{~kW}$ & 460,40 & 470,53 & 479,00 & 498,11 & 502,47 \\
\hline neste $40 \mathrm{~kW}$ & 921,10 & 94,36 & 958,30 & 996,52 & 1205,92 \\
\hline Resten 1558,72 & 1593,01 & 1621,68 & 1686,36 & 2512,33 & \\
\hline \multicolumn{6}{|c|}{$\mathrm{CO}_{2}$ Utslipp kr pr gram/km } \\
\hline første 120 gram/km & - & - & - & - & 40,2 \\
\hline neste 20 gram/km & - & - & - & - & 190,94 \\
\hline neste 40 gram/km & - & - & - & - & 502,47 \\
\hline Resten - & - & - & - & 1406,9 & \\
\hline $\begin{array}{l}\text { Vrakpantavgiften } \\
\text { pr kjøretøy }\end{array}$ & 1300 & 1300 & 1300 & 1300 & 1500 \\
\hline
\end{tabular}

Tabell 25. Engangsavgiften på kjøretøy i Norge 2002-2007. Kilde: Tollvesenet. ${ }^{51}$

\section{Vektårsavgiften}

Vektårsavgiften ble innført 1. oktober 1993. Sammen med autodieselavgiften erstattet vektårsavgiften kilometeravgiften, som tidligere ble betalt av biler som ikke gikk på bensin, samt av tilhengere med totalvekt over 2 tonn. I dag består vektårsavgiften av en gradert årsavgift etter vekt og en miljødifferensiert årsavgift for dieseldrevne kjøretøy. Vektårsavgiften pålegges kjøretøy og kombinasjoner av kjøretøy med tillatt totalvekt på 7,5 tonn og over. ${ }^{52}$ Vektavgiften ble endret i statsbudsjettet for 2008 slik at lettere biler fikk en reduksjon på 6,23 prosent, men tunge biler fikk en økning på 2,5 prosent.

\section{Omregistreringsavgift}

Fra 1. januar 2008 skal det i henhold til lov 19. juni 1959 nr. 2 om avgifter vedrørende motorkjøretøyer og båter betales avgift til statskassen ved omregistrering av mopeder, motorsykler, personbiler, busser, lastebiler, trekkbiler, varebiler, kombinerte biler, campingbiler, biltilhengere, herunder semitrailere og campingtilhengere med egenvekt over $350 \mathrm{~kg}$. Takstene vises i tabell 26. 
Personbiler, busser (nok)

Registreringsår

2007,2008

2006

$2005 \quad 1997-2004$

Før 1996

\begin{tabular}{lrrrrr} 
Egenvekt t.o.m. 800 kg & 8.344 & 6.321 & 4.765 & 3.185 & 1.484 \\
\hline Egenvekt over $800 \mathrm{~kg}$ og t.o.m. 1200 kg & 11.394 & 8.860 & 6558 & 4.547 & 1.484 \\
\hline Egenvekt over 1200 kg og t.0.m. 1600 kg & 16.384 & 12.726 & 9.393 & 6.321 & 1.484 \\
\hline Egenvekt over 1600 kg. & 21.218 & 16.384 & 11.979 & 8.177 & 1.484 \\
\hline
\end{tabular}

Tabell 26. Takster for omregistreringsavgift for personbiler og busser.

Kilde: Finansdepartementet 2008. ${ }^{53}$

53 http://www.regjeringen.no/ upload/FINNedlegg/sl/stortingets_skattevedtak_for_inn tekts\% C3\% A5ret 2008.pdf

54 http://www.elbil.no/

55 http://www.sft.no/artikkel__ 40874.aspx

\section{Elbiler i Norge}

Norge har i dag rundt 2000 elektrisk drevne biler, ifølge Norstart - norsk elbilforening. ${ }^{54}$ Største konsentrasjonen av elbiler er i Oslo. Det er to norske produsenter av elbil: Think og Buddy. I Norge får elektriske kjøretøyer en rekke goder. Elektriske kjøretøy er fritatt fra engangsavgiften og årsavgiften ${ }^{55}$ og kan kjøre i kollektivfeltet. De er også fritatt for parkeringsavgift. Elbiler er også fritatt fra å betale bompenger. Sammen med fritakene for engangs- og årsavgifter gjør mulighetene for å bruke kollektivfelt og fri parkering $\mathrm{g}$ at elbilene får klare fordeler i forhold til andre biler. Dette har sannsynligvis bidratt til at det er relativt mange elbiler i Norge sammenlignet med nabolandene.

Det er hittil solgt nesten 1200 Prius hybrid i Norge siden den første bilen ble registrert i 2000 ifølge Toyota Norge. 


\section{5. Øvrige skatter og skattefradrag}

\section{Arbeids- og tjenestereiser}

Man får fradrag for kostnader knyttet til reiser mellom hjem og fast arbeidsplass (arbeidsreiser) uavhengig av de virkelige utgiftene eller hvilken type kommunikasjonsmiddel som blir brukt. Fradraget blir regnet etter korteste strekning mellom hjem og fast arbeidsplass etter en sats på kr 1,40 per km (kr 0,70 per $\mathrm{km}$ for reiser over $35000 \mathrm{~km}$ per år). Det utregnede fradraget skal reduseres med et bunnfradrag. Bunnfradraget var kr 12800 for inntektsåret 2006. Fradraget skal regnes særskilt for hver skatteyter. Ektefeller ha hvert sitt fradrag selv om de kjører sammen. Det samme gjelder kameratkjøring. 56

For transport i jobbsammenheng (tjenestereiser) får statsansatte $1,5 \mathrm{kr} / \mathrm{km}$ etter $5 \mathrm{~km}$ hvis en reiser med sykkel, men $3,5 \mathrm{kr} / \mathrm{km}$ ved bruk av egen bil (fra første kilometer). Disse statlige satsene brukes også av mange andre bedrifter når de skal refundere transportkostnader som de ansatte har fått i jobbsammenheng. Satsene danner også grunnlag for hvor mye som kan refunderes skattefritt. Dersom en bedrift ønsker å gi sine ansatte like mye i refusjon ved bruk av sykkel som ved bruk av egen bil, vil differansen bli skattepliktig.

\section{Parkering}

Det offentlige samt private kan i dag ilegge avgift for bruk av parkeringsplasser på sine arealer. Det er derimot ikke mulig for myndighetene å kreve at det ilegges avgift for parkering på private områder. Den norske skattelovgivningen sier generelt at økonomiske fordeler som oppnås i et arbeidsforhold, skal skattlegges på linje med annen lønn. Til tross for dette praktiseres det ingen fordelsbeskatning av gratis parkeringsplasser som arbeidsgiver gir sine ansatte. Dersom arbeidsgiver vil gi sine ansatte gratis kollektivtransport, må arbeidstakerne sannsynligvis måtte fordelsbeskatte av i hvert fall deler av denne verdien.

\section{Bomringen i Oslo}

Bomringen i Oslo ble opprettet i 1990 for å skaffe penger til utbygging av veidnettet og noe kollektivtransport. Den fungerer slik at bilister som kommer kjørende inn til Oslo må betale en avgift, avhengig av størrelse på kjøretøyet som vist i tabell 27, til myndighetene. Bomringen i Oslo har vært kontroversiell og skulle avikles først 1997 og så senere i 2007. Men i den såkalte Oslopakke 3, som ennå ikke er vedtatt, ble den presentert på ny som en tidsavgrenset inntektskilde og skal være med å finansiere transporttiltak i Oslo i 20 år videre.

56 http://www.skatteetaten.no Templates/Brosjyre.aspx?i $d=7344$ \&epslanguage $=N O$ \&chapter $=57385$ \#kapittelt ekstrådrag etter reiseavstand

57 https://www.fjellinjen.no/ Faktura_og_betaling/gjeldende takster/no

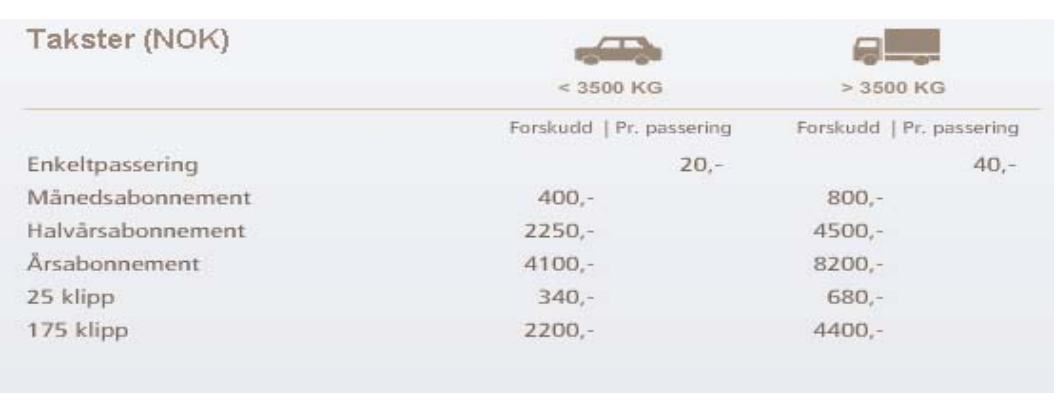

Tabell 27. Priser på bomringen i Oslo 2008. Kilde: Fjellinjen AS. ${ }^{57}$ 
Bomringen har finansiert en rekke prosjekter i Oslo-området, blant annet tunneler på E18 og Ring 1. I starten fikk veiprosjekter 80 prosent av inntektene fra bomringene, men andelen økte i 2002. Det ligger an til at om lag halvparten av inntektene i framtida vil gå til kollektivtransport, også til drift av tilbudet. Ifølge Transportøkonomisk institutt går kun 30 prosent av alle bilreiser i Oslo og Akershus gjennom bomringen. ${ }^{58}$

Skepsisen til bompengeringen var stor før ringen åpnet, men er siden redusert. Ut ifra det er det mulig å si at brukerbetaling i større grad er akseptert. ${ }^{59}$ Ifølge Transportøkonomisk institutts rapport Effekter av hovedvegutbygging i Bergen og 0 slo ${ }^{60}$ er rundt 245000 biler som passerer bomringen daglig i Oslo (i én retning). Rapporten antyder 3-5 prosent trafikkavvisning som følge av innføring av bomringen i Oslo, og den peker på at trafikkveksten i Oslo kommet på hovedveiene og ikke på lokalveiene, noe som har vært målet med utbygging av flere veiene som er finansiert av bomringen.

\section{Køprising/veiprising}

Også i flere andre norske byer er det tatt i bruk brukerbetaling (bomringer) for å skaffe midler til infrastrukturutbygging. Det har imidlertid vært et økende ønske om å bruke ulike økonomiske virkemidler for å redusere trafikkbelastningen i bestemte områder og til bestemte tider. Det er derfor mulig å innføre såkalt veiprising eller køprising, der formålet er å begrense trafikken for å bedre miljøet og/eller bedre trafikkavviklingen. Dette må vedtas av lokale myndigheter. Ingen byer i Norge har tatt i bruk køprising/veiprising ennå.

\section{Hvordan styrer skatterne trafikkens miljøbelastning}

Drivstoffprisene påvirker transportsektorens miljøprestasjoner på flere måter. Prisene har en innvirkning på det totale transportomfanget, både på kort sikt og enda mer på lang sikt, siden endringer i arealbruk, valg av bosted og arbeidsplass m.m. etter hvert også påvirkes. Prisene har en innflytelse på transportmiddelfordeling, men også på hvor mye drivstoff hver enkelt bil bru-

58 http://www.sak.oslo.kommune.no/dok/Bys\% 5 C2004\% 5 CSFK\% 5 C2004007993-1.htm

59 http://www.akershus.no/ index.php?page_id=304\&art icle id $=3688$

60 http://www.toi.no/ getfile.php/

Publikasjoner/T\% D81\% 2ora pporter/2005/770-2005/rapport.pdf

61 http://www.vegvesen.no/ $n t p /$ transportanalyser/pdf/20 o80117_sammrapp_grunnprog.pdf

62 http://www.regjeringen.no /nn/dep/fin/Dokument/NOU ar/2007/NOU-2007$8 / 10 / 1 / 1 . h t m l ? i d=478102$

63 http://www.ssb.no/vis/magasinet/fire_hjul/art-2008-0703-01.html ker.

I prognosearbeidet for Nasjonal transportplan 2010-2019 oppgis priselastisiteten på drivstoff til å være på mellom -0,15 0g -0,2061, mens det i NOU 2007: $8 \mathrm{En}$ vurdring av særavgiften $e^{62}$ henvises til elastisiteter på -0,52, -0,40 og -0,46, der førstnevnte er en langsiktig priselastisitet (20 år) til varegruppa "driftsutgifter til eget kjøretøy", som følgelig må gjelde for mer enn bare drivstoff. Til tross for stort sprik gir disse elastisitetene oss et signal om at drivstoffprisen faktisk har en betydelig innvirkning på drivstofforbruk og miljøbelastning.

Den gjennomsnittlige norske husstanden bruker bare 3,2 prosent av sine totale forbruksutgifter på drivstoff, ifølge SSB. ${ }^{63}$ Det er også et poeng at avgiftene på diesel i dag er lavere enn på bensin, til tross for at klimaeffekten av å forbrenne én liter diesel er omtrent den samme som for bensin.

Som vist i tabell 59 og 60 har salget av forholdsvis drivstoffgjerrige personbiler 
$\emptyset k t$ vesentlig etter at engangsavgiften ble lagt om fra 1. januar 2007.

Helhetseffekten er derimot noe usikker. Antall registrerte personbiler økte med 3,4 prosent, med nesten 71 000, fra 31. desember 2006 til 31. desember 2007. Foregående år var veksten på om lag 55 000. Det er flere faktorer som påvirker bilsalget, noe som betyr at sammenhengene er usikre. Uansett er det viktig å ha dette med i betraktningene når avgiftssystemer utformes, da en økt bilpark vil fort kunne resultere i økt bilkjøring og dermed svekke eller reversere de positive effektene av avgiftsomleggingene. Større insentiver til å velge biler med lavt $\mathrm{CO}_{2}$-utslipp kan også resultere $\mathrm{i}$ at det blir flere dieselbiler og dermed øt lokal luftforurensning. Lavere avgifter på diesel enn på bensin har trukket $\mathrm{i}$ samme retning. Sistnevnte effekt har nok avtatt eller opphørt i det siste siden markedsprisen på diesel har økt.

Siden det neppe er politisk mulig å øke drivstoffavgiftene så mye at miljøbelastningen fra transportsektoren reduseres tilstrekkelig, vil engangsavgiften fortsatt være et viktig virkemiddel, både for å dempe etterspørselen etter biler (som igjen påvirker transportmengden), og for å bidra til at bilparkens gjennomsnittsutslipp per kjørte kilometer reduseres.

Erfaringene i Norge har vært at dieselandelen har økt, uten at det samtidig ble tatt i bruk virkemidler som motvirker veksten i utslipp av nitrogenoksider og partikler fra dieselforbrenning. Fra 1. janaur 2008 er det innført en gradert årsavgift som skal stimulere til kjøp av partikkelfiltre på nye biler. Vi er imidlertid usikre på om dette er et riktig og tilstrekkelig virkemiddel for å redusere omfanget av lokal luftforurensing fra dieselbiler. Både dette og risikoen for at endringer av engangsavgiften kan øke bilparkens omfang, minner oss om at det viktigste i transportpolitikken må være å arbeide for å redusere transportomfanget, samtidig som teknologiske forbedringer fases inn.

Dagens pendlerfradrag for reise til/fra arbeid er en transportsubsidie. Bunnfradraget gjør at folk med kort avstand til sin arbeidsplass, ikke får noe fradrag. Fradraget motarbeider samfunnets mål om å redusere transportomfanget, som er et viktig element i de rikspolitiske retningslinjene for samordnet areal- og transportplanlegging (rundskriv T-5/93 fra Miljøverndepartementet). ${ }^{64}$

Kjøregodtgjørelsene som gis av arbeidsgiver, vil kunne stimulere til bruk av egen bil framfor kollektivtransport eller sykkel. For arbeidstakere som regner alle andre kostnader enn drivstoffkostnadene som faste, i og med at de har bilen "uansett", vil kunne tenke at de tjener betydelig på å bruke egen bil framfor å få refundert faktiske kostnader ved bruk av kollektivtransport.

Parkeringspolitikken påvirker i stor grad folks mulighet til å bruk bil. Parkeringsavgiftene påvirker derfor trafikkens miljøbelastning. Det er imidlertid viktig at parkeringspolitikken ses i et regionalt perspektiv. Dersom én kommu-

64 http://www.regjeringen.no/ $\mathrm{nb} / \mathrm{dep} / \mathrm{md} / \mathrm{dok} / \mathrm{rund}$ skriv/1993/T-593-Areal-og. transportplanlegging.html?i $d=107851$ ne fører en streng parkeringspolitikk, kan det bli mer kjøring til og fra nabokommunen, dersom den har konkurrerende tjenestetilbud. Revisjonen av planog bygningsloven gir nye muligheter for regional planlegging der blant annet parkeringspolikken kan "strammes inn" på tvers av flere kommuner. 
Den norske skattelovgivningen sier generelt at økonomiske fordeler som oppnås i et arbeidsforhold, skal skattlegges på linje med annen lønn. Til tross for dette praktiseres det ingen fordelsbeskatning av gratis parkeringsplasser som arbeidsgiver gir sine ansatte. Dette er både miljømessig uheldig og en forskjellbehandling av bilister på bekostning av syklister. Dersom arbeidsgiver vil gi sine ansatte gratis kollektivtransport, må arbeidstakerne sannsynligvis måtte fordelsbeskatte av i hvert fall deler av denne verdien. Transportøkonomisk institutt har gjort beregninger som viser en sterk sammenheng mellom gratis parkeringsplass på jobb og bruk av bil til jobb. ${ }^{65}$

Køprising/veiprising vil være et effektivt virkemiddel for å redusere trafikken i byene, slik at miljøbelastningen og køene reduseres. Også næringslivet vil kunne oppnå besparelser gjennom reduserte tidskostnader, noe rapporten Vegprising, kollektivtiltak og sosial ulikhet ${ }^{66}$ fra Transportøkonomisk institutt konkluderer med. Vi mener det også er et viktig poeng at køprising/veiprising kan gi grunnlag for betydelige tilleggsinntekter som kan brukes til blant annet å styrke kollektivtilbudet, slik at flere får et bedre alternativ til bilbruk.

\section{Konkrete forslag til endringer}

- Drivstoffavgiftene må økes. I første omgang må autodieselavgiften og $\mathrm{CO}_{2}$ avgiften på mineralolje (diesel) økes til bensinnivå. Uavhengig av dette må $\mathrm{CO}_{2}$-avgiften generelt trappes opp, som virkemiddel for å nå målet om maksimalt to graders temperaturstigning.

- Bilavgiftene må skjerpes slik at de i større grad premierer biler med lavt forbruk og gjør biler med høyt forbruk dyrere. Det bør opprettes et nytt trinn i $\mathrm{CO}_{2}$-komponenten i engangsavgiften for biler med utslipp lavere enn 100 gram $\mathrm{CO}_{2}$ per kilometer, slik at disse får et større avgiftsmessig fortrinn. Biler med utslipp på 140 gram $\mathrm{CO}_{2}$ per kilometer må bli vesentlig dyrere. Avgiftssatsene må skjerpes ytterligere etter hvert som det kommer flere bilmodeller med lavere utslipp, for eksempel plug-in-hybrider.

- Varebilene må ilegges engangsavgift etter samme prinsipp og størrelse som personbiler.

- Dagens ordninger med pendlerfradrag og kjøregodtgjørelser må gjennomgås i et miljøperspektiv, med tanke på endringer som demper transportomfanget og stimulerer til bruk av kollektivtransport og sykkel framfor bruk av privatbil.

- Myndighetene må åpne for at kommunene kan ilegge miljøavgift på private parkeringsplasser, blant annet i byer og rundt kjøpesentre.

65 http://www.toi.no/ getfile.php/Publikasjoner/T $\%$ D $81 \%$ 2orapporter/2003/677-2003/T\% D8Irapport\% 20677-03.pdf

66 http://www.toi.no/ getfile.php/Publikasjoner/T $\%$ D81\% 2orapporter/2005/815-2005/T\% D8Irapport-815-2005.pdf
- Fordelsbeskatning av arbeidsgiverbetalt parkeringsplasser må praktiseres. Sekundært må gratis kollektivtransport betalt av arbeidsgiver unntas fordelsbeskatning. En løsning kan være at arbeidsgivere som tilbyr sine arbeidstakere gratis parkering, blir pålagt å gi alle sine ansatte penger som tilsvarer verdien av gratisparkeringsplass. De ansatte kan da velge om de vil bruke pengene på parkeringsplass eller andre ting, for eksempel kollektiv- 
transport. I California er det en lov som pålegger dette i områder med dårlig luftkvalitet.

- Staten må gjøre det attraktivt for byene å innføre køprising/veiprising. Den såkalte belønningsordningen for bedre kollektivtransport og mindre bilbruk må økes vesentlig og brukes aktivt for å premiere byer som innfører restriksjoner på biltrafikken. 


\section{DEL II: 4. Sverige}

\section{Målsättningar}

1998 antog den svenska riksdagen som etappmål att "utsläppen av koldioxid från transporter i Sverige bör år 2010 ha stabiliserats på 1990 års nivå" "67. Detta beslut har därefter vid flera tillfällen bekräftats, senast vid riksdagens behandling av den transportpolitiska propositionen våren $2006^{68}$.

I realiteten har dock utsläppen fortsatt att öka. De politiska åtgärder i form av regleringar och skattehöjningar som beslutats har inte varit tillräckliga för att nå målet.

Nuvarande utveckling innebär att transportsektorns utsläpp 2010 beräknas vara närmare 10 procent högre än 1990. Till 2020 förutses en ökning med 18 procent, jämfört med 1990.

\begin{tabular}{lrrrrrr} 
& $\mathbf{1 9 9 0}$ & $\mathbf{2 0 0 5}$ & $\mathbf{2 0 1 0}$, prog & $\mathbf{2 0 2 0 , \text { prog }}$ & $\mathbf{1 9 9 0 - 2 0 1 0}$ & $\mathbf{1 9 9 0 - 2 0 2 0}$ \\
Vägtrafik & 16829 & 18675 & 18440 & 20120 & $+10 \%$ & $+20 \%$ \\
\hline Flyg & 688 & 674 & 650 & 630 & $-6 \%$ & $-8 \%$ \\
\hline Sjöfart & 549 & 546 & 540 & 630 & $-2 \%$ & $+15 \%$ \\
\hline Bantrafik & 116 & 74 & 70 & 50 & $-40 \%$ & $-57 \%$ \\
\hline Övrig & 258 & 305 & 300 & 300 & $+16 \%$ & $+16 \%$ \\
\hline Summa & 18440 & 20274 & 20000 & 21730 & $+8,5 \%$ & $+17,8 \%$ \\
\hline
\end{tabular}

Tabel 28. Historiska och prognosticerade utsläpp av växthusgaser från olika transportslag i Sverige, kton koldioxidekvivalenter. ${ }^{69}$

På vägtrafiksidan ökar utsläpp främst inom den tunga lastbilstrafiken. Även utsläppen från lätta lastbilar har ökat mycket kraftigt. På personbilssidan har utsläppen däremot, åtminstone tillfälligt, stabiliserats.

\begin{tabular}{lcccccc} 
År & Personbil & Lätt lastbil & Buss & Tung lastbil & $\begin{array}{c}\text { Motorcykel } \\
\text { och moped }\end{array}$ & Totalt \\
\hline 1980 & 10,83 & 0,60 & 0,53 & 2,87 & 0,03 & 14,85 \\
\hline 1985 & 11,14 & 0,72 & 0,58 & 2,96 & 0,03 & 15,43 \\
\hline 1990 & 12,38 & 1,06 & 0,60 & 2,97 & 0,05 & 17,06 \\
\hline 1995 & 12,62 & 1,12 & 0,67 & 3,22 & 0,06 & 17,69 \\
\hline 2000 & 12,33 & 1,18 & 0,61 & 3,39 & 0,07 & 17,59 \\
\hline 2005 & 12,58 & 1,66 & 0,59 & 4,02 & 0,12 & 18,90 \\
\hline 2007 & 12,34 & 1,81 & 0,56 & 4,19 & 0,14 & 19,04 \\
\hline
\end{tabular}

Tabel 29. Utsläpp av växthusgaser från vägtrafiken i Sverige, miljoner ton koldioxidekvivalenter. ${ }^{70}$

\footnotetext{
67 Prop 1997/98:56 Transportpolitik för en hållbar utveckling

68 Prop. 2005/06:160 Moderna transporter

69 Prognoser för utsläpp och upptag av växthusgaser. Delrapport 1 i Energimyndighetens och

Naturvårdsverkets underlag till Kontrollstation 2008. Energimyndigheten/Naturvårdsverket 2007

70 Vägverket PM 2008-03-31
} 


\section{Grundfakta om bilbestånd, bränsleförbrukning och försäljning av person- och tjänstebilar}

\section{Den svenska drivmedelsmarknaden}

Traditionellt har andelen dieselpersonbilar varit mycket låg på den svenska marknaden. Bensinen har därför dominerat som källa till koldioxidutsläpp. Under senare år har mönstret förändrats. Den tunga trafiken med lastbilar har växt snabbt och under 2006-07 har andelen dieselpersonbilar av nybilsförsäljningen ökat kraftigt. Konsekvensen är att förbrukningen av bensin nu är något lägre än den var 1990. Samtidigt ökar dieselförbrukningen snabbt.

\begin{tabular}{|c|c|c|c|c|c|}
\hline & 1975 & 1985 & 1995 & 2005 & 2007 \\
\hline Bensin, 'ooo $\mathrm{m}^{3}$ & 4376 & 5068 & 5763 & 5508 & 5268 \\
\hline Diesel, ’ooo m³ & 2308 & 2446 & 3119 & 4271 & 4683 \\
\hline
\end{tabular}

\section{Tabel 30. Drivmedelsförsäljning 1975-2005}

2002-2004 slopades stegvis punktskatterna på förnybara drivmedel. EUs bränslekvalitetsdirektiv tillåter låginblandning av etanol och rapsmetylester (RME) i bensin resp. diesel upp till en nivå på fem procent. Skattebefrielsen har lett till att praktiskt taget all bensin och diesel som säljs i Sverige innehåller fem procent etanol resp RME. Tillsammans med den volymmässigt betydligt mindre betydelsefulla försäljningen av E85 (85 volymprocent etanol, 15 procent bensin) ${ }^{72}$ har detta lett till att de direkta, fossila koldioxidutsläppen från vägtrafiken under senare år (åtminstone tillfälligt) bedöms ha stabiliserats.

EUs importtullar är så utformade att etanol som används i E85 är befriad från importtull, medan etanol för låginblandning är belagd med hög tull. Konsekvensen är att nästan all etanol för låginblandning hämtas från EU medan den etanol som ingår i E85 importeras från Brasilien (producerad av sockerrör). Klimatnyttan av den etanol som ingår i E85 är, generellt sett, betydligt större än nyttan av den låginblandade etanolen. Bägge etanolslagen är dock skattebefriade.

71 Källa: Svenska petroleuminstitutet

72 Vintertid är andelen etanol några procentenheter lägre. 73 FAME = Fatty Acidic Methyl Esther. En grupp av biologiskt baserade oljor. I praktiken utnyttjas nästan enbart rapsmetylester (RME).

\begin{tabular}{lrr} 
per år & 2006 & 2007 \\
\hline Bensin, 'ooo m & 5363 & 5268 \\
\hline E85, 'ooo m³ & 63 & 112 \\
\hline Diesel, 'ooo m', totalt & 4422 & 4683 \\
\hline Diesel med FAME'3, 'ooo m ${ }^{3}$ & 1278 & 2893 \\
\hline Diesel utan FAME', 'ooo m ${ }^{3}$ & 3015 & 1384 \\
\hline
\end{tabular}

Tabel 31. Drivmedelsförsäljning i Sverige 2006-2007 


\begin{tabular}{lr}
\hline Etanol, låginblandad 5\% i bensin & $1,9 \%$ \\
\hline Etanoldelen i E85-bränsle & $0,7 \%$ \\
\hline Biogas & $0,4 \%$ \\
\hline RME/FAME låginblandad 2 \% i dieselolja ${ }^{74}$ & $1,3 \%$ \\
\hline Etanol bussbränsle & $0,2 \%$ \\
\hline
\end{tabular}

Tabel 32. Andel av energileverans till vägtransporter i Sverige $2007^{75}$

\section{Den svenska bilparken}

Ur ett europeiskt perspektiv är den svenska personsparken extremt bränsletörstiga. Sedan lång tid tillbaka är de certifierade koldioxidutsläppen per km från nysålda bilar i Sverige ca 20 procent högre än genomsnittet inom EU. En förklaring är att andelen dieselbilar historiskt har varit lägre än i övriga EU.

Huvudskälet är dock att svenska bilar är tyngre och mera motorstarka än genomsnittet. ${ }^{76}$ Utvecklingen under de senaste 10 åren har varit dramatisk vikt och motoreffekt hos nya bensinbilar har i genomsnitt ökat 11-12 procent. För dieselbilar är motsvarande siffror drygt 20 resp 40 procent! Under 1990talet steg genomsnittsåldern hos bilar i trafik från 7,4 till 9,2 år. 2007 var medelåldern 9,0 år.

$\begin{array}{llllllllllll}1995 & 1997 & 1998 & 1999 & 2000 & 2001 & 2002 & 2003 & 2004 & 2005 & 2006 & 2007\end{array}$

\begin{tabular}{|c|c|c|c|c|c|c|c|c|c|c|c|c|}
\hline \multicolumn{13}{|l|}{ Bensinbilar } \\
\hline $\begin{array}{l}\text { 3ränsleförbruk- } \\
\text { ing 1/100 km }\end{array}$ & 9,3 & 9,0 & 8,7 & 8,5 & 8,3 & 8,4 & 8,4 & 8,3 & 8,3 & 8,1 & 7,9 & 7,8 \\
\hline $\begin{array}{l}\text { oldioxidutsläpp } \\
\mathrm{CO}_{2} / \mathrm{km}\end{array}$ & 222 & 217 & 213 & 208 & 203 & 199 & 199 & 198 & 198 & 197 & 190 & 185 \\
\hline Motoreffekt, kW & 92 & 92 & 92 & 93 & 95 & 95 & 101 & 101 & 103 & 103 & & \\
\hline ikt, kg & 1278 & 1280 & 1268 & 1277 & 1297 & 1285 & 1330 & & & 1436 & & \\
\hline \multicolumn{13}{|l|}{ Dieselbilar } \\
\hline $\begin{array}{l}\text { Sränsleförbruk- } \\
\text { ing l/100 km }\end{array}$ & 7,5 & 6,6 & 6,5 & 6,5 & 6,5 & 6,7 & 6,8 & 7,0 & 7,0 & 7,0 & 6,9 & 6,6 \\
\hline $\begin{array}{l}\text { Koldioxidutsläpp } \\
\mathrm{CO}_{2} / \mathrm{km}\end{array}$ & 199 & 189 & 175 & 174 & 175 & 176 & 178 & 183 & 188 & 189 & 183 & 176 \\
\hline Motoreffekt, kW & 73 & 77 & 77 & 78 & 81 & 85 & 92 & 100 & 103 & 105 & & \\
\hline ikt, kg & 1399 & 1410 & 1370 & 1403 & 1457 & 1464 & 1523 & & & 1719 & & \\
\hline \multicolumn{13}{|l|}{ Genomsnitt } \\
\hline $\begin{array}{l}\text { oldioxidutsläpp } \\
\mathrm{CO}_{2} / \mathrm{km}\end{array}$ & 221 & 216 & 204 & 201 & 197 & 198 & 197 & 198 & 197 & 194 & 189 & 181 \\
\hline jenomsnitt EU-15 & 186 & & & & & & & & 162 & 161 & 160 & \\
\hline
\end{tabular}

Tabel 33. Bränsleförbrukning, certifierade koldioxidutsläpp, vikt och motoreffekt i nya personbilar i Sverige 1995-200677

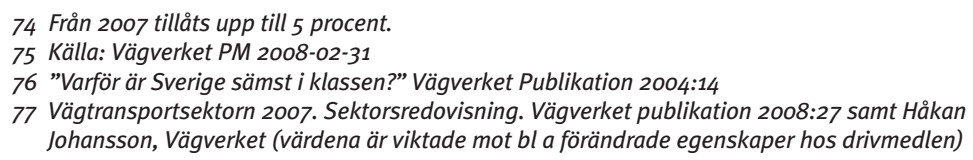


Antalet personbil i trafik växer stadigt. Vid årsskiftet 2007/08 fanns drygt 4,2 miljoner personbilar i trafik. Det motsvarar 485 bilar per 1000 invånare, dvs nästan en bil på varannan svensk. Till detta kommer ca 500000 lastbilar (varav ca 85 procent är lätta lastbilar, dvs med en totalvikt under 3,5 ton) samt drygt 13000 bussar. $^{78}$

\begin{tabular}{|c|c|c|c|c|c|}
\hline År & 1975 & 1985 & 1995 & 2005 & 2006 \\
\hline Personbilar i trafik & 2760264 & 3151195 & 3630760 & 4156674 & 4202463 \\
\hline Lastbilar i trafik & 156648 & 217778 & 307709 & 461161 & 479794 \\
\hline $\begin{array}{l}\text { varav lätta lastbilar } \\
<3,5 \text { ton }\end{array}$ & & & & 384775 & 401110 \\
\hline
\end{tabular}

\section{Tabel 34. Registrerade bilar i trafik i Sverige $1975-2005^{79}$}

Efter att särskilda skatteförmåner införts för bilar som kan köras på hög inblandning av etanol (flexifuel-bilar), på gas samt för elhybridbilar ${ }^{80}$, och skatten dessutom tagits bort på förnybara drivmedel, har försäljningen av dessa fordonstyper ökat kraftigt. Även försäljningen av lätta lastbilar har ökat kraftigt - på tio år har försäljningen nästan tredubblats.

\begin{tabular}{|c|c|c|c|c|c|c|}
\hline År & Totalt & $\begin{array}{r}\text { varav } \\
\text { diesel }\end{array}$ & $\begin{array}{r}\text { varav } \\
\text { flexifuel }\end{array}$ & varav gas & $\begin{array}{r}\text { varav } \\
\text { elhybrid }\end{array}$ & $\begin{array}{r}\text { Lätta lastbilar } \\
<3,5 \text { ton }\end{array}$ \\
\hline 1996 & 180181 & 8962 & & & & 14697 \\
\hline 1997 & 225263 & 17074 & & & & 20216 \\
\hline 1998 & 253430 & 27786 & & & & 25812 \\
\hline 1999 & 295249 & 21332 & & & & 27806 \\
\hline 2000 & 290529 & 18236 & & & & 31278 \\
\hline 2001 & 246581 & 13687 & & & & 28569 \\
\hline 2002 & 254589 & 17735 & & & & 28275 \\
\hline 2003 & 261206 & 20095 & & & & 27975 \\
\hline 2004 & 264212 & 21141 & & & & 30837 \\
\hline 2005 & 274301 & 26622 & 10425 & 1421 & 1947 & 34686 \\
\hline 2006 & 282766 & 55780 & 25870 & 2679 & 2840 & 39398 \\
\hline 2007 & 306799 & 106358 & 35185 & 1471 & 3391 & 44084 \\
\hline
\end{tabular}

Tabel 35. Försäljning av personbilar resp lätta lastbilar 1996-2007

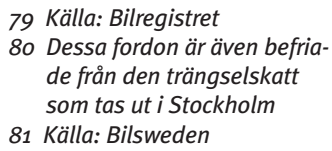




\section{Beskatning af drivmiddel}

Den svenska beskattningen av drivmedel består av två delar - energiskatt respektive koldioxidskatt.

- Energiskatten är inte bestämd enligt någon särskild princip. Om den relateras till de olika drivmed-lens energiinnehåll är energiskatten på diesel betydligt lägre än motsvarande skatt på bensin. Enligt finansdepartementet motsvarar skillnaden ett skattebortfall för staten på ca 8 miljarder kr per $\mathrm{år}^{82}$

- Koldioxidskatten är generell och ska gälla för alla fossila bränslen (även t ex eldningsolja och kol) i förhållande till de koldioxidutsläpp respektive bränsle orsakar. Från 1 januari 2008 är basen för skatten 101 öre per kg $\mathrm{CO}_{2}$. Skattesatserna är dock uttryckta i kr per liter eller $\mathrm{m}^{3}$ och motsvarar inte exakt 101 öre per $\mathrm{kg} \mathrm{CO}_{2}$. För bensin är skatten i realiteten något lägre än så, medan koldioxidskatten på diesel motsvarar 114 öre per $\mathrm{kg} \mathrm{CO}_{2} \cdot{ }^{8_{3}}$

\begin{tabular}{|c|c|c|c|c|}
\hline & Energiskatt & Koldioxidskatt & Summa & Marknadsandel 2006 \\
\hline $\begin{array}{l}\text { Motorbensin } \\
\text { miljöklass } 1\end{array}$ & 2,95 kr per liter & 2,34 kr per liter & 5,29 kr per liter & $>99 \%$ \\
\hline $\begin{array}{l}\text { Diesel } \\
\text { miljöklass } 1\end{array}$ & 1277 kr per m³ & $2883 \mathrm{kr} \mathrm{per} \mathrm{m}^{3}$ & $4160 \mathrm{kr}$ per $\mathrm{m}^{3}$ & $98,8 \%$ \\
\hline Gasol & - & $1584 \mathrm{kr}$ per ton & $1584 \mathrm{kr}$ per ton & \\
\hline Naturgas & - & $1282 \mathrm{kr}$ per ton & $1282 \mathrm{kr}$ per ton & \\
\hline
\end{tabular}

Tabel 36. Punktskatt på drivmedel från 1 januari $2008^{84}$

\begin{tabular}{lcc}
\hline & Bensin & Diesel \\
\hline 1960 & 0,42 & 0,32 \\
\hline 1970 & 0,58 & 0,40 \\
\hline 1980 & 1,39 & $0,11^{\star}$ \\
\hline 1990 & 2,99 & $1,08^{\star}$ \\
\hline 1995 & 4,01 & 2,89 \\
\hline 2000 & 4,47 & 2,92 \\
\hline 2005 & 4,96 & 3,64 \\
\hline
\end{tabular}

82 Prop 2007/08:1, utgiftsområde 22, sid 19

83 Skattenivåerna baseras på den tekniska sammansättning som gällde för bensin resp diesel när koldioxidskatten infördes i böärjan av 1990-talet.

84 Källa: Skatteverket

85 Om det innan dess införs en s k kvotplikt, dvs om oljebolagen blir skyldiga att uppna t ex 5 eller 10 procents biodrivmedelsandel, måste skatteundantaget slopas.
Tabel 37. Drivmedelsskatter i Sverige 1960-2005, löpande penningvärde, kr/l * 1974-1993 togs kilometerskatt ut av dieselbilar

"Koldioxidneutrala" drivmedel är sedan 2004 helt befriade från energi- och koldioxidskatt. De drivmedel som i praktiken omfattas är i första hand etanol, RME och biogas. I bensin och diesel med 5 procents inblandning av etanol resp RME är skatten per liter drivmedel 95 procent av siffrorna ovan, dvs skatten på bensin (Mk1) är normalt ca 5,03 kr per liter, på diesel (Mk 1) ca 3952 kr per m³ . För E85 ( 85 \% etanol, 15 \% bensin) tas skatt endast ut för bensindelen, dvs 0,79 kr per liter. Skattebefrielsen för "koldioxidneutrala" drivmedel ska, enligt riksdagsbeslut, bestå till och med 2013. 
20022003200420052006

Andel med 5 procent etanol

$21 \quad 45$

Tabel 38. Andel bensin med låginblandning av etanol \%

Nedsättning eller befrielse från skatt

För bensin och diesel som används inom jordbruk, skogsbruk och vattenbruk gäller att energi- och koldioxid-skatterna är nedsatta med 79 procent (= samma nedsättning som gäller för sådan industri som inte ingår i EUs utsläppshandel). För vissa fartyg gäller total skattebefrielse. All energianvändning inom spårtrafik är dessutom befriad från skatt, vilket motsvarar ett skattebortfall för staten på drygt 1 miljard kr per år. ${ }^{15}$ 


\section{Beskatning af køretøj}

\section{Registrerings-/försäljningsskatt}

I Sverige tas inte längre ut någon särskild försäljningsskatt i samband med att en bil för första gången registreras. Den tidigare "bilaccisen" avvecklades i huvudsak 1995/96 och slopades slutligen helt 2001. Vid avskaffandet var skattenivån 6,40 kr/kg, dvs i allmänhet 7-10 o0o kr per fordon, vilket vid 1990-talets mitt motsvarade 3-5 procent av försäljningspriset. I försäljningsstatistiken är det svårt att se några effekter av skattens slopande. Från 1987 var dock skatten differentierad efter bilens avgasprestanda. Denna differentiering bidrog starkt bl a till ett snabbt införande av katalyrisk avgasrening. I samband med att den "miljödifferentierade" bilaccisen slopades, övergick man till att stimulera nya bilar med lägre avgaser via upp till fem års befrielse från fordonsskatt (se nedan).

Fordonsskatt - personbilar

Fordonskatten betalas per år (eller del av år). Beskattningen är olika för nyare respektive äldre fordon.

- För personbilar av 2005 års modell eller äldre baseras skatten på vikten.

Vikt, kg

Ej diesel, kr per år

Diesel, kr per år

\begin{tabular}{|c|c|c|}
\hline $0-900$ & 720 & 2187 \\
\hline $901-1000$ & 903 & 2741 \\
\hline $1001-1100$ & 1086 & 3295 \\
\hline $1101-1200$ & 1269 & 3849 \\
\hline $1201-1300$ & 1452 & 4403 \\
\hline $1301-1400$ & 1635 & 4957 \\
\hline $1401-1500$ & 1818 & 5511 \\
\hline $1501-1600$ & 2001 & 6065 \\
\hline $1601-1700$ & 2184 & 6619 \\
\hline $1701-1800$ & 2367 & 7173 \\
\hline $1801-1900$ & 2550 & 8727 \\
\hline $1901-2000$ & 2733 & 8281 \\
\hline $2001-2100$ & 2916 & 9835 \\
\hline $2101-2200$ & 3099 & 9389 \\
\hline $2201-2300$ & 3282 & 9943 \\
\hline $2301-2400$ & 3465 & 10497 \\
\hline $2401-2500$ & 3648 & 11051 \\
\hline $2501-2600$ & 3831 & 11605 \\
\hline $2601-2700$ & 4014 & 12159 \\
\hline $2701-2800$ & 4197 & 13713 \\
\hline $2801-2900$ & 4380 & 13267 \\
\hline $2901-3000$ & 4563 & 13821 \\
\hline
\end{tabular}

Tabel 39. Fordonsskatt 1 januari 2008 personbilar 2005 års modell eller äldre 
- För fordon av 2006 års modell eller yngre eller för äldre fordon som uppfyller kraven för miljöklass 2005 (=EUs avgasklass Euro 4) samt för el- och hybdridfordon baseras skatten på bilarnas certifierade koldioxidutsläpp. För bilar som kan köras på alkohol eller gas är koldioxidfaktorn nedsatt. För dieselbilar gällde fram till utgången av 2007 en multiplikator på 3,5. Från 1 januari 2008 är multiplikatorn sänkt. För fordon registrerade före 1 januari 2008 är skatten förhöjd med en faktor 3,3, för bilar registrerade efter 1 januari 2008 är faktorn 3,15.

\begin{tabular}{|c|c|c|c|}
\hline Fordonstyp & Grundbelopp & Koldioxidfaktor & Multiplikator \\
\hline $\begin{array}{l}\text { Alternativa drivmedel } \\
\text { (alkohol eller natur-/biogas) }\end{array}$ & 360 kr/år & $\begin{array}{l}10 \mathrm{kr} / \mathrm{ar} \text { per kg CO2 per km - } \\
100 \mathrm{~g} \mathrm{CO} 2 \text { per km }\end{array}$ & \\
\hline Ej diesel (bensin, gasol, el) & 360 kr/år & $\begin{array}{l}15 \mathrm{kr} / \text { år per kg CO2 per km - } \\
100 \mathrm{~g} \mathrm{CO} 2 \text { per km }\end{array}$ & \\
\hline $\begin{array}{l}\text { Diesel registrerad } \\
\text { före } 1 \text { jan } 2008\end{array}$ & $360 \mathrm{kr} / \mathrm{ar}$ & $\begin{array}{l}15 \mathrm{kr} / \mathrm{a} r \text { per kg CO2 per km - } \\
100 \mathrm{~g} \mathrm{CO} 2 \text { per km }\end{array}$ & 3,3 \\
\hline $\begin{array}{l}\text { Diesel registrerad } \\
\text { efter } 1 \text { jan } 2008\end{array}$ & $360 \mathrm{kr} / a ̊ r$ & $\begin{array}{l}15 \mathrm{kr} / \mathrm{a} r \text { per kg CO2 per km - } \\
100 \mathrm{~g} \mathrm{CO} 2 \text { per km }\end{array}$ & 3,15 \\
\hline
\end{tabular}

Tabel 40. Fordonsskatt, personbilar 2006 års modell eller yngre

\section{Exempel:}

1. Etanolbil: Saab 9-3 Biopower 1.8t, $178 \mathrm{~g} \mathrm{CO} 2$ per km Fordonsskatt: $360+(178-100) \times 10 \mathrm{kr}=(360+780) \mathrm{kr}=1140 \mathrm{kr} / \mathrm{ar}$

2. Dieselbil: Saab 9-3 1.9TTiD, 149 g CO2 per km Fordonsskatt: $3,15 \times(360+(149-100) \times 15) \mathrm{kr}=3,15 \times(360+735) \mathrm{kr}$ $=3449,25 \mathrm{kr} / \mathrm{år}$

3. Bensinbil: Saab 9-3 1.8t, 183 g CO2 per km Fordonsskatt: $360+(183-100) \times 15 \mathrm{kr}=(360+) \mathrm{kr}=1605 \mathrm{kr} / \mathrm{år}$

- För personbilar registrerade i 36 inlandskommuner från norra Värmland och norrut minskas fordonsskatten med $384 \mathrm{kr}$ per år.

- För dieselbilar, som är utrustade med partikelfilter och som registrerades under 2006 eller 2007 görs ett avdrag på 6000 kr innan fordonsskatten behöver betalas.

\section{Fordonsskatt - lätta lastbilar och husbilar}

För lätta lastbilar och husbilar (personbilar, klass II) höjdes fordonsskatten vid årsskiftet 2007/08 med ca 45 procent. Exempel på tidigare nivåer inom parentes: 


\begin{tabular}{lll} 
Vikt & Ej diesel, kr per år & Diesel, kr per år \\
$0-1300$ & $720(720)$ & $2187(1613)$ \\
\hline $1301-1400$ & $903(771)$ & 2339 \\
\hline $1401-1500$ & 1067 & 2398 \\
\hline $1501-1600$ & 1231 & $2457(1613)$ \\
\hline $1601-1700$ & 1396 & 2517 \\
\hline $1701-1800$ & 1525 & 2695 \\
\hline $1801-1900$ & 1654 & 2873 \\
\hline $1901-2000$ & $1783(1233)$ & $3015(2105)$ \\
\hline $2001-2100$ & 1912 & 3229 \\
\hline $2101-2200$ & 2041 & 3407 \\
\hline $2201-2300$ & 2170 & 3585 \\
\hline $2301-2400$ & 2299 & 3763 \\
\hline $2401-2500$ & 2428 & 3941 \\
\hline $2501-2600$ & $2557(1773)$ & $4119(2843)$ \\
\hline $2601-2700$ & 2686 & 4297 \\
\hline $2701-2800$ & 2815 & 4475 \\
\hline $2801-2900$ & 2944 & 4653 \\
\hline $2901-3000$ & 3073 & 4831 \\
\hline $3001-$ & $3197(2205)$ & $5018(3461)$ \\
\hline
\end{tabular}

Tabel 41. Fordonsskatt 1 januari 2008, lätta lastbilar och personbilar klass II (=husbilar)

\section{Fordonsskatt övriga fordon}

För övriga fordon - tunga lastbilar, bussar, dragfordon, släpvagnar m m - gäller att fordonsskatterna i huvudsak är viktrelaterade, men också kopplade till drivmedel, antal axlar m m. Totalt gäller inte mindre än 30 olika skattetabeller. Som mest kan ett fordon betala ca $40000 \mathrm{kr}$ i årlig fordonsskatt. De tyngsta fordonen måste normalt även betala vägavgift ("eurovignett"), en skatt som är samordnad mellan Danmark, Belgien, Luxemburg och Nederländerna (även Tyskland ingår på särskilda villkor). (se nedan under Vägavgift)

\section{Vägavgift/eurovignett}

För att få tillträde till de största svenska vägarna (ungefär Europavägarna) måste tunga fordon (i första hand alla fordon över 12 ton samt dragfordon över 7 ton) betala en särskild vägavgift, som regleras i EUs s k eurovignettdirektiv. Avgiften är tidsbaserad och kan gälla per dag, vecka, månad eller helt år. Avgiften är differentierad efter fordonets vikt, antal axlar samt avgasklass. För fordon med högst 3 axlar är vägavgiften 6 831-8 $743 \mathrm{kr}$ per år, för fordon med fler axlar 11 385- 14117 kr per år. ${ }^{86}$ Dygnsavgiften är alltid 72 kr per dygn. Svenskregistrerade fordon måste alltid betala full årsavgift. Utländska fordon behöver endast betala avgift för den del av färden som sker på huvudvägnätet,

86 På grund av förändringar $i$ växelkursen SEK/euro avviker dessa avgiftsnivåer från de summor som är angivna i det s $k$ Eurovignett-direktivet dvs i princip Europavägar. På det övriga vägnätet kan fordonen köra utan att betala vägavgift. Fordon som betalt vägavgift i ett av de länder som ingår i Eurovignett-samarbetet får utan extra kostnad utnyttja det avgiftsbelagda vägnätet även i övriga deltagande länder. 


\section{Försäkringspremieskatt}

1 juli 2007 infördes en skatt på trafikförsäkringspremier. Skatten betalas av försäkringsbolagen och motsvarar ca 32 procent av trafikförsäkringen. För den enskilde försäkringstagaren kan påslaget variera betydligt, men i genomsnitt beräknas det motsvara ca $600 \mathrm{kr}$ per år. Syftet med skatten är att trafikanterna direkt ska täcka de kostnader för sjukpenning $\mathrm{m}$ m som är kopplade till trafikolyckor. Intäkterna från den nya skatten avses utnyttjas för att sänka de lönebaserade sjukförsäkringsavgifter arbetsgivarna betalar. 


\section{5. Øvrige skatter og skattefradrag}

\section{Miljöbilspremie $^{87}$}

Till den privatperson som köper en ny s k miljöbil utgår fr o $\mathrm{m} 1$ april 2007 ett särskild statligt bidrag på 10000 kr per bil. Regeringen har lovat att bidraget ska bestå t $0 \mathrm{~m}$ 2009. Villkoret är att den bil man köper uppfyller något av följande villkor:

- Konventionella bilar (inklusive hybrider) som uppfyller avgaskraven Euro 4 (Miljöklass 2005): Koldioxidutsläppen vid blandad körning får uppgå till $\max 120 \mathrm{~g} / \mathrm{km}$. För dieseldrivna bilar får partikelutsläppet vara max 5 $\mathrm{mg} / \mathrm{km}$ (krav om partikelfilter).

- Alternativbränsledrivna bilar (bilar som kan drivas med andra bränslen än bensin, diesel eller gasol): Den certifierade bränsleförbrukningen vid blandad körning får inte överstiga 0,92 liter bensin eller 0,97 kubikmeter gas per $10 \mathrm{~km}$ (motsvarar $215 \mathrm{~g} \mathrm{CO}_{2}$ per $\mathrm{km}$ ). Om en bilmodell med manuell växellåda uppfyller kravet ges premien även till motsvarande modell med automatväxel.

- Elbilar: Elenergiförbrukningen per 100 kilometer får inte överstiga 37 kilowattimmar. (Denna typ av fordon finns i dagsläget inte på marknaden.)

\section{Trängselskatt}

Sedan 1 augusti 2007 måste fordon som färdas in eller ut ur Stockholms centrum betala trängselskatt till staten - se karta. Skatten tas ut måndag-fredag 06.30-18.30 och är 10, 15 eller 20 kr per passage. Högst är skatten under rusningstid på morgnar och eftermiddagar. Per dygn är skatten maximerad till 60 kronor per fordon. Undantagna från skatten är bl a större bussar (över 14 ton), utryckningsfordon, handikappfordon och fordon som kan drivas på etanol och gas samt elhybrydbilar.

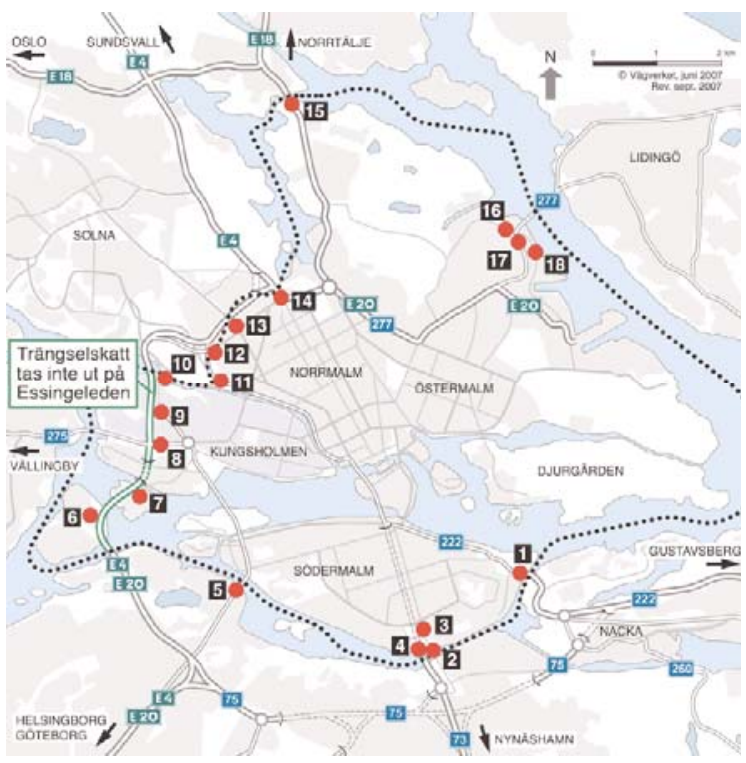

Figur 14. Trängselsskat-område i Stockholm 


\section{Beskattning av förmånsbil samt olika trafikrelaterade skatteavdrag}

Som en del av lönen kan en arbetsgivare erbjuda den anställde tillgång till en bil som den anställde även kan använda utanför arbetet. I förmånen kan dessutom ingå drivmedel. Systemet är mycket utbrett - ca 225000 anställda har tillgång till förmånsbil.

För att beskatta värdet av förmånsbil tillämpas schablonregler som i princip är helt baserade på bilens försäljningspris. Nuvarande regler fastställdes i huvudsak 1997. Eftersom en mycket stor del av nybilsförsäljningen - 35-40 procent är baserad på förmånsbilar anses villkoren för förmånsbilar ha stor betydelse för den svenska bilparkens sammansättning och därmed för vägtrafikens miljöpåverkan..$^{88}$

Som framgår av nedanstående tabell ${ }^{89}$ (som omfattar de tio mest sålda bilmodellerna i Sverige 2006) är försäljningen av nya Saab- och Volvobilar till privatpersoner mycket liten - nästan hela försäljningen går till företag, som i de flesta fall låter en anställd disponera bilen. Att Saab och Volvo gör bilar med hög bränsleförbrukning och höga utsläpp påverkar den svenska utsläppsstatistiken kraftigt.

\begin{tabular}{lllllll} 
& Bilmodell & $\begin{array}{l}\text { Total } \\
\text { försäljning }\end{array}$ & $\begin{array}{l}\text { Varav till } \\
\text { privatpersoner }\end{array}$ & $\begin{array}{l}\text { Varav till } \\
\text { företag }\end{array}$ & $\%$ \\
\hline 1 & Volvo V70 & 29539 & 8441 & 28,5 & 21098 & 71,5 \\
\hline 2 & Saab 9-5 & 14494 & 1305 & 9,0 & 13189 & 91,0 \\
\hline 3 & Volvo V50 & 12578 & 3153 & 25,1 & 9425 & 74,9 \\
\hline 4 & Saab 9-3 & 11130 & 3186 & 28,6 & 7944 & 71,4 \\
\hline 5 & VW Golf & 9016 & 3405 & 37,8 & 5611 & 62,2 \\
\hline 6 & VV Passat & 8857 & 1715 & 19,4 & 7142 & 80,6 \\
\hline 7 & Ford Focus & 8715 & 2459 & 28,2 & 6256 & 71,8 \\
\hline 8 & Toyota Corolla 8235 & 2861 & 34,7 & 6374 & 65,3 \\
\hline 9 & Peugeot 307 & 6415 & 3656 & 57,0 & 2759 & 43,0 \\
\hline 10 & Skoda Fabia & 5603 & 3663 & 65,4 & 1940 & 34,6 \\
\hline
\end{tabular}

\section{Tabel 42. Salg af bestemte bilmærketyper 2006}

88 Se t ex "Bilförmånsreglernas effekt på utsläpp av koldioxid från bilar". Inregia och WSP, maj 2004 på uppdrag av Naturvårdsverket

89 Källa: Dagens Industri 2007 01-25

90 Basbeloppet är ett bergepp som ingår i en rad lagstiftningar och avtal, vilket gör det möjligt att löpande justera t ex olika
Förmånsbeskattningen - $i$ korthet

Den som har tillgång till förmånsbil måste betala skatt på det beräknade värdet av denna förmån. På motsvarande sätt måste arbetsgivaren betala sociala avgifter $\mathrm{m} \mathrm{m}$ på detta belopp som om det betalats ut som kontant lön. Beräkningen av det beskattningsbara förmånsvärdet är mycket komplicerad och beskrevs på detta sätt av regeringen när det föreslogs 1996:

"Värdet skall bestämmas till o,3 basbelopp ${ }^{90}$ med tillägg av ett ränterelaterat belopp och ett prisrelaterat belopp. Det ränterelaterade beloppet skall bestämmas till 75 \% av statslåneräntan vid utgången av november månad andra året 
före taxeringsåret multiplicerad med nybilspriset för årsmodellen. För bilar med ett nybilspris för årsmodellen som uppgår till högst 7,5 basbelopp skall det prisrelaterade beloppet beräknas till $9 \%$ av nybilspriset. För bilar med ett nybilspris som överstiger 7,5 basbelopp skall beloppet beräknas till $9 \%$ av 7,5 basbelopp med tillägg av $20 \%$ av den del av nybilspriset som överstiger 7,5 basbelopp." ${ }^{11}$

I praktiken betyder reglerna att det är ofördelaktigt att välja en billig (=bränslesnål) förmånsbil eftersom det i botten finns ett fast belopp på o,3 basbelopp som inte påverkas av hur dyr bilen är. Mest fördelaktigt blir systemet för den anställde och för arbetsgivaren om man väljer en bil med ett nybilspris på ca 7,5 basbelopp, vilket för 2008 motsvarar $307500 k^{292}$. Tillgång till en förmånsbil med ett nybilspris på 7,5 basbelopp höjer den beskattningsbara inkomsten per år med ca 50000 kr, vilket för förmånstagaren innebär en ökad inkomstskatt på $15000-27500$ kr per år.

Det beskattningsbara beloppet kan begränsas på flera olika grunder:

- Om förmånstagaren använder bilen mer än 3000 mil i tjänsten reduceras förmånsvärdet med 75 procent.

- Om förmånsbilen kan köras på alkohol (=flexifuelbil) reduceras förmånsvärdet till 80 procent av det som gäller för motsvarande bensinmodell (nedsättningen får inte överstiga 8000 kr). För gasbilar reduceras värdet till 60 procent av ordinarie förmånsvärde (nedsättning max $16000 \mathrm{kr}$ ).

Om arbetsgivaren betalar drivmedel för förmånstagaren, ska kostnaden för detta beskattas. Vid inkomstbeskattningen (dock ej vid beräkning av sociala avgifter) anges det beskattningsbara förmånsvärdet till 1,2 gånger priset på det drivmedel arbetsgivaren har betalat. För de förmånstagare som betalar 50-55 procent inkomstskatt på marginalen, betyder detta att deras bränslekostnad motsvarar mindre än 60 procent av det pris andra konsumenter betalar. ${ }^{22}$

Tillgång till fri parkeringsplats vid arbetet beskattas inte. Värdet av förmånsbil är därför i realiteten ofta betydligt högre för förmånsbilsinnehavare i storstäderna än i övriga landet. Kostnaden för en parkeringsplats i Stockholms innerstad kan vara närmare $40000 \mathrm{kr}$ per år, dvs av samma storleksordning som den beskattningsbara förmånen.

\section{Reseavdrag}

\section{Avdrag för resa till och från arbetsplats}

Vid inkomstbeskattningen får man i Sverige göra avdrag för resekostnader till och från arbetsplatsen. Reglerna är i korthet följande:

- För att få göra avdrag måste resekostnaderna för hela året överstiga 8000 kronor och arbetsplatsen ligga minst två kilometer från bostaden.

91 Prop 1996/97:19 Beskattning av bilförmån, $m . m$

92 Detta är förklaringen till att begreppet "7,5 basbelopp" ofta förekommer i svenska bilannonser.
- Om avståndet mellan hemmet och arbetsplatsen är över $5 \mathrm{~km}$ och om man vinner minst 2 timmar per dag på att köra med egen bil får man (2008) göra avdrag för resa med egen bil med 18,50 kr per mil (10 km) för den kostnad som överstiger $8000 \mathrm{kr}$ per år. Använder man förmånsbil och betalar drivmedlet själv, får man göra avdrag för utgift för diesel med 6,50 kronor per mil och för annat drivmedel med 9,50 kronor per mil. 


\section{Hvordan styrer skatterne trafikkens miljøbelastning}

Att koldioxidutsläppen från transporterna stiger, indikerar att de styrmedel som finns inte fungerar. Bristerna är många.

- Drivmedelsskatterna är för låga, det gäller särskilt skatten på diesel, som både per liter och omräknat till körsträcka är betydligt lägre än på bensin. Det låga dieselpriset betyder att de utsläppsminskningar som skulle kunna uppnås genom en ökad andel dieselbilar till en betydande del, kanske helt och hållet, går förlorad. Med lägre rörlig kostnad måste man räkna med att bilköparna väljer större och mera bränsleslukande fordon. Över tiden måste man också räkna med att en lägre rörlig kostnad leder till ökade körsträckor.

- Att det saknas en försäljningsskatt på personbilar i Sverige ger utrymme både för större vinstmarginaler för leverantörer och försäljare av bilar på den svenska marknaden och för lägre priser. Att priserna på bilar är låga leder till ett genomsnittligt högre bilinnehav och till att svenska bilköpare har råd att välja dyrare - och därmed normalt mera bränsleslukande modeller.

- Miljöbilspremien sänker priserna på bilar, vilket rimligen driver upp bilinnehavet ytterligare. Premien förstärker trenden mot fler flexifuelbilar, som oftast är relativt tunga och bränslekrävande. Den starkaste effekten är dock sannolikt att det etablerats en marknad för verkligt bränslesnåla fordon $\left(\mathrm{CO}_{2}\right.$-utsläpp under $120 \mathrm{~g}$ per $\left.\mathrm{km}\right)$. Dessa bilmodeller fanns i stort sett inte på den svenska marknaden för 2-3 år sedan. Sedan premien infördes har försäljningen av dessa bilmodeller ökat 7-8 gånger. Premien leder därmed till att de genomsnittliga utsläppen från nya bilar minskar, men eftersom den samtidigt betyder att antalet bilar i trafik växer och att den rörliga kostnaden för att köra de nya, bränslesnåla bilarna är låg, är det osäkert om premien bidrar till totalt sett lägre koldioxidutsläpp.

- Att en så stor del av nybilsförsäljningen går till förmånsbilar betyder att bilparkens sammansättning till stor del styrs av reglerna för förmånsbilsbeskattning. Eftersom dessa regler systematiskt gynnar fordon som kostar drygt 300000 kr i inköp, förstärker skattereglerna utvecklingen mot större, tyngre och mera bränsletörstiga bilar. Om den som har förmånsbil även får drivmedlet betalt av arbetsgivaren, blir drivmedelskostnaden betydligt lägre än för den normale bilisten, vilket ytterligare försvagar motiven att välja en bränslesnål förmånsbil. Dessutom leder det sannolikt till längre körsträckor. Skattebefrielsen för etanol och biogas bidrar till att minska koldioxidutsläppen i trafik, men förstärker samtidigt trenden mot större, tyngre och mera bränsletörstiga bilar.

- Reglerna för förmånsbilar, men även de olika undantag och premier för miljöbilar som finns, är uppenbarligen strömlinjeformade för att stärka marknaden för svensktillverkade Volvo och Saab-bilar. Eftersom både Saab och Volvo i sin produktutveckling är starkt inriktad på den nordamerikanska 
marknaden driver regelverket den svenska bilparken i samma riktning som den amerikanska, dvs stora, tunga bilar med starka motorer och hög bränsleförbrukning.

- Att reseavdragen är baserade på den beräknade resekostnaden istället för avståndet uppmuntrar skattebetalarna att redovisa så höga resekostnader som möjligt. I praktiken innebär det att man uppmuntras att göra avdrag för bilresa. Även om fusket antas vara omfattande (många påstår sig åka i egen bil men reser i själva verket kollektivt eller i någon annans bil) bidrar avdragens utformning till ökat bilåkande, dvs ökade utsläpp. En vanlig missuppfattning är att reseavdragen har störst betydelse för glesbygderna - $\mathrm{i}$ verkligheten görs hälften av reseavdragen i de tre storstadslänen (Stockholm, Skåne, Västra Götaland).

Några inslag i beskattningen ger sannolikt positiva miljöeffekter Att fordonsskatten för nya bilar kopplats till de certifierade koldioxidutsläppen gör det mera attraktivt att välja en bränslesnål bil. Att skatten är lägre på bilar som kan köras på E85 och gas bidrar dock till att hålla uppe energianvändningen hos flexifuel- och gasbilar.

Försäkringspremieskatten ökar kostnaden för att äga bil, vilket rimligen leder till minskat bilinnehav.

\section{Förslag till reformer av den svenska trafikbeskattningen ${ }^{93}$}

\section{Höj koldioxidskatten}

Regeringens klimatberedning föreslog i februari att de svenska utsläppen av växthusgaser till 2050 ska minska med 75-90 procent. Ska detta mål kunna nås, måste trafikens koldioxidutsläpp minskas radikalt. Den mest träffsäkra åtgärden är att höja koldioxidskatten på fossila drivmedel. På 10-15 års sikt är det rimligt att räkna med att priset på bensin och diesel av klimatskäl behöver fördubblas. För att ge de bästa förutsättningarna för privatpersoner och företag att anpassa sig, bör en sådan förändring göras stegvis och successivt och kombineras med andra åtgärder som gör bilarna mera bränslesnåla och kollektivoch spårtrafik mera attraktiv.

\section{Reformera beskattningen av dieseltrafiken}

Per liter kan en dieselpersonbil rulla en ca 40 procent längre sträcka än motsvarande bensinbil. De samhällskostnader som är förknippade med körsträckan (t ex avgaser, buller och vägslitage) är därför i motsvarande mån högre per liter diesel än per liter bensin. Med en teknikneutral beskattning bör energiskatten på diesel därför vara ca 40 procent högre än motsvarande skatt på bensin, dvs energiskatten på diesel bör höjas från 1 till ca 4 kr per liter. Med en sådan höjning kan den årliga fordonsskatten - som idag är drygt 3 gånger högre för en dieselbil än för en bensinpersonbil - likställas. Det skulle innebära en sänkning med knappt 70 procent för dieselbilen.

93 "Hur dyr måste soppan bli?" Naturskyddsföreningen 2007
Med högre dieselskatt och lägre fordonsskatt på dieselbilar skulle styrsignalerna till bilisterna bli enhetliga och teknikneutrala. 
40 procent av den tunga trafiken på de svenska vägarna görs av lastbilar i internationell trafik. Bilarna har ofta tankar på 1.000 liter eller mera, dvs de har möjlighet att fylla på diesel i det land där dieselskatten är lägst. Konsekvensen är att en isolerad höjning av dieselskatten i Sverige skulle leda till en omfattande gränshandel - lastbilarna skulle tanka sina bilar i grannländerna. En förutsättning för att kunna höja den generella dieselskatten är därför att man kan tillämpa olika skattenivåer för lätta och tunga dieselfordon.

Lösningen ligger i det förslag till justering av EUs energibeskattningsdirektiv som kommissionen presenterade i mars 2007. ${ }^{44}$ Om detta förslag genomförs kan länder som inför km-skatt på tunga fordon återbetala en del av dieselskatten till de fordon som betalar km-skatt.

3. Inför stimulans för snabbare introduktion av Euro 6-kraven för lätta fordon Från 2014 införs inom EU nya, skarpare avgaskrav på lätta bilar ("Euro 6"). Den viktigaste nyheten är att normen för kväveoxidutsläpp från dieselbilar skärps kraftigt. Med skatterabatter (t ex en differentierad fordons- eller registreringsskatt) till Euro 6-bilar kan vi snabbt få en dieselbilsflotta som är lika ren som bensinbilarna. Därmed förhindras att en övergång till dieselpersonbilar leder till kraftigt ökade utsläpp av kväveoxider från personbilsflottan.

4. Avskaffa eller gör en radikal omläggning av systemet med förmånsbilar Nuvarande system för beskattning av förmånsbilar är en viktig förklaring till att svenska bilar i genomsnitt drar 20 procent mera bränsle än EU-snittet.

Systemet bör avskaffas, i andra hand bör förmånsvärdena baseras på koldioxidutsläpp - en lösning som prövats framgångsrikt i Storbritannien.

\section{Inför en $\mathrm{CO}_{2}$-och effektrelaterad registreringsskatt på nya, lätta fordon} Om försäljningsskatten återinförs och differentieras efter bilarnas $\mathrm{CO}_{2}$-utsläpp kan bilparken snabbt förbättras radikalt. Många EU-länder har registreringseller försäljningsskatter. För att undvika dubbelbeskattning som försvårar gränsöverskridande handel bör inom EU ett system för återbetalning av registreringsskatt vid ändring av registreringsland upprättas. För att inte motverka bilparkens förnyelse bör även fordonsskatten höjas.

\section{Skärp $\mathrm{CO}_{2}$-relateringen av fordonsskatten på lätta fordon}

Med en starkare $\mathrm{CO}_{2}$-differentiering än idag blir bilparken mera bränslesnål. Nuvarande system fungerar, men ger svagare effekt än en motsvarande registreringsskatt. Fordonsskatten stimulerar fordonsparkens förnyelse, vilket kan vara positivt.

7. Ändra reglerna för reseavdrag (avdrag för sträcka, ej schablonkostnad) Nuvarande system gynnar ensidigt privatbilism och utspritt boende och har dessutom lett till ett mycket omfattande fusk.

\section{Inför lokal/regional kontroll över trängselskatten}

Trängselskatt ger sänkta utsläpp samtidigt som köerna försvinner. Att riksdagen kontrollerar styrmedlet blockerar ytterligare införande och försvårar ett effektivt nyttjande. 


\section{DEL II: 4. Vägtrafikbeskattningen i Finland}

\section{Målsætninger}

Den finländska vägtrafikbeskattningen har tills nyligen nästan helt uteslutande haft fiskalt syfte. Inkomsterna från vägtrafikbeskattningen har varit viktiga för statens finanser. För att stärka den finländska klimatpolitiken finns numera ett politiskt antaget mål om att transportsektorns koldioxidutsläpp 2010 inte får överstiga nivån 1990. Likväl är prognosen att utsläppen under denna period kommer att öka med närmare 13 procent.

\begin{tabular}{lcccc} 
& 1990 & 2005 & $2010, p r o g$ & 2020, prog \\
\hline Väg & 10,9 & 12 & 12,15 & 12,8 \\
\hline Flyg & 0,8 & 1,1 & 1,2 & 1,32 \\
\hline Sjöfart & 2,8 & 3,7 & 3,3 & 3,2 \\
\hline Tåg & 0,25 & 0,24 & 0,25 & 0,25 \\
\hline Summa & 14,8 & 17,0 & 16,9 & 17,6 \\
\hline
\end{tabular}

Tabel 43. Utsläpp av växthusgaser från transportsektorn i Finland, miljoner ton CO2-ekvivalenter

Källa: Statens tekniska forskningscentrum. LIPASTO, 2006

Med undantag för perioden med ekonomisk tillbakagång i början av 1990-talet har bilparken, liksom de totala körsträckorna, löpande stigit. Med nuvarande utveckling beräknas vägtrafiken 1990-2010 öka med 30 procent och till 2020 med ytterligare 9 procent. 


\section{Grundfakta om bilbestand, brændstofforbrug, miljøbe- lastning $\mathrm{mv}$}

Den finska drivmedelsmarknaden

Dieselanvändningen har traditionellt varit mindre än bensinanvändningen, vilket förklaras av den höga, fasta skatten på dieselpersonbilar. På senare tid har detta förhållande ändrats. Under 2007 översteg konsumtionen av diesel för första gången bensinförbrukningen. Fossilgas och biogas används i begränsad utsträckning som fordonsbränsle - 2007 fanns endast sex tankställen för gas. Etanol i form av E85 finns inte till försäljning.

\begin{tabular}{lll} 
& 2006 & 2007 \\
\hline Bensin & 2576 & 2481 \\
\hline Diesel & 2549 & 2607 \\
\hline
\end{tabular}

Tabel 44. Drivmedelsanvändningen 2006 och 2007 (miljoner liter)

Den finländska bilparken

Den finländska personbilsflottan är gammal, bränsletörstig och växer snabbt. 2006 vara medelåldern hos registrerade personbilar 10,5 år. Snittåldern hos bilar som skrotades var 18,1 år. Den genomsnittliga bränsleförbrukningen hos nya bensinbilar var 7,7 liter/100 km, för nya dieselbilar 6,9 l/100 km. De genomsnittliga $\mathrm{CO}_{2}$-utsläppen från ny personbilar var $180 \mathrm{~g} / \mathrm{km}$ för bensinbilar och $176 \mathrm{~g} / \mathrm{km}$ för dieselbilar.

Under den ekonomiska nedgången i början av 9o-talet minskade antalet registrerade bilar temporärt.

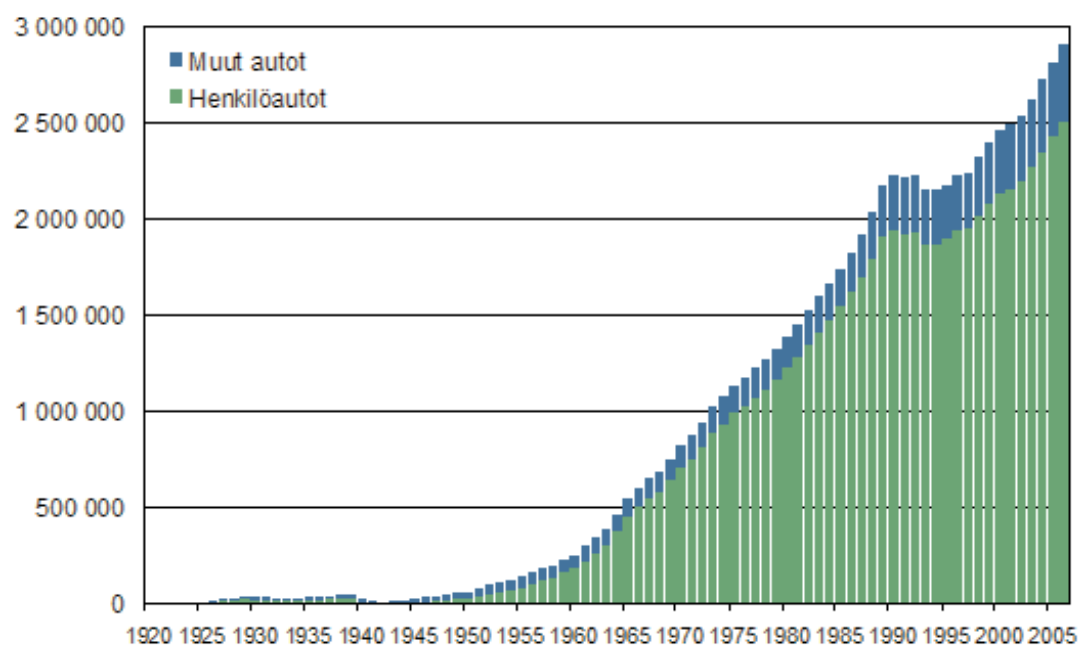

Figur 15. Antalet registrerade bilar i Finland $1922-2006$

Grönt = personbilar, Blå = övriga fordon, Källa: Statistikcentralen 


\begin{tabular}{lrr}
\multicolumn{1}{l}{ År } & Personbilar & Lastbilar \\
\hline 1975 & 996284 & 50905 \\
\hline 1985 & 1546094 & 52019 \\
\hline 1995 & 1900855 & 48556 \\
\hline 2005 & 2430345 & 87191 \\
\hline 2007 & 2570356 & 97187 \\
\hline
\end{tabular}

Tabel 45. Registrerade bilar i bruk, Källa: Statistikcentralen

Andelen dieselbilar bland nya personbilar har varit låg (15-20 \%) jämfört med övriga EU. Under senare år har andelen stigit snabbt och är nu nästan 30 procent.

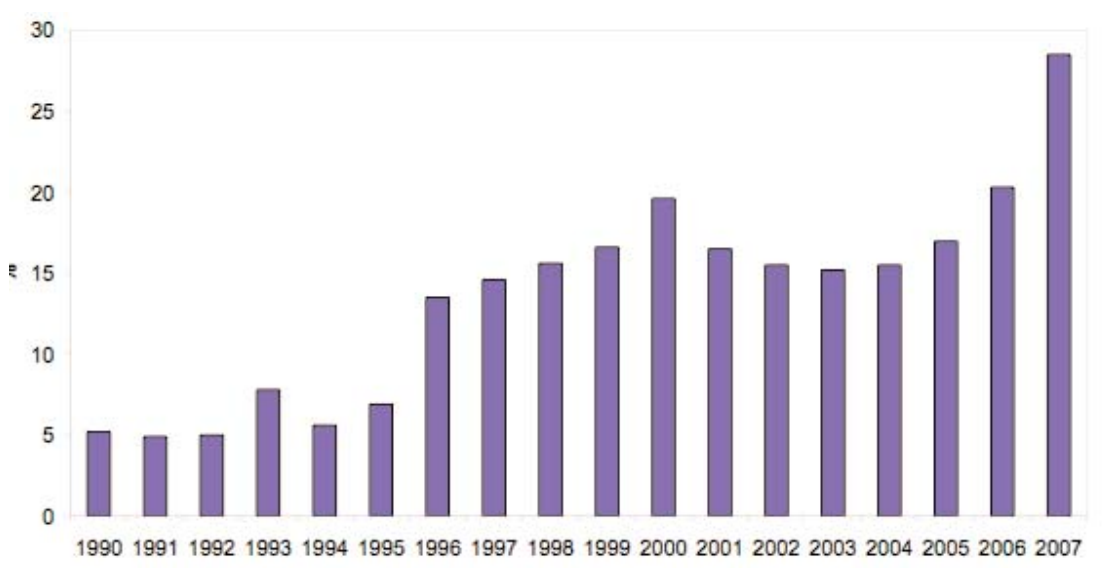

Figur 16. Dieselandel nya personbilar 1990-2007 Källa: Statistikcentralen

\begin{tabular}{rrrrc} 
& Totalt & Diesel & Bensin & Övrigt \\
\hline 2000 & 134603 & 26330 & 108273 & 0 \\
\hline 2001 & 109428 & 18016 & 91412 & 0 \\
\hline 2002 & 117033 & 18196 & 98837 & 0 \\
\hline 2003 & 147405 & 22364 & 125042 & 1 \\
\hline 2004 & 142635 & 22103 & 120536 & 0 \\
\hline 2005 & 148161 & 25139 & 123020 & 2 \\
\hline 2006 & 145700 & 29512 & 116128 & 60 \\
\hline 2007 & 125608 & 35782 & 89789 & 36 \\
\hline
\end{tabular}

Tabel 46. Försålda nya personbilar och lätta lastbilar (< 3,5 ton) 1996 - 2007 Källa: Fordonsförvaltningscentralen (www.ake.fi)

För nya dieselbilar ökade $\mathrm{CO}_{2}$-utsläppen 2000-2006 med drygt 10 procent. För bensinbilar har snittutsläppen sjunkit något. I genomsnitt har utsläppen varit oförändrade. 


\begin{tabular}{lrrr} 
Ar & Bensin & Diesel & Totalt \\
\hline 2000 & 183 & 159 & 179 \\
\hline 2001 & 182 & 160 & 179 \\
\hline 2002 & 181 & 165 & 178 \\
\hline 2003 & 180 & 167 & 178 \\
\hline 2004 & 182 & 168 & 180 \\
\hline 2005 & 181 & 172 & 180 \\
\hline 2006 & 180 & 176 & 179 \\
\hline 2007 & 179 & 173 & $?$ \\
\hline $2008 / 3$ & 168 & 158 & $?$ \\
\hline
\end{tabular}

Tabel 47. Genomsnittliga $\mathrm{CO}_{2}$-utsläpp från nyregistrerade bilar, $\mathrm{g} / \mathrm{km}$ Källor: Regeringens proposition 147/2007 samt Fordonsförvaltningscentralen (www.ake.fi) 


\section{Beskatning af drivmiddel}

Drivmedelsbeskattningen består av grundaccis, tilläggsaccis och försörjningsberedskapsavgift. Acciserna är renodlade skatter, försörjningsberedskapsavgiften tillfaller en särskild försörjningsberedskapsfond. Grundaccisen är lägre för svavelfria kvaliteter, se tabel 48.

\begin{tabular}{lccccc} 
& Grundaccis & Tilläggsaccis & $\begin{array}{c}\text { Försörjnings } \\
\text { beredskapsavgift }\end{array}$ & Totalt 2008 & Totalt 2007 \\
\hline Bensin, övrig & 59,89 & 4,78 & 0,68 & 65,35 & 61,42 \\
\hline Diesel, svavelfri & 30,67 & 5,38 & 0,35 & 36,4 & 31,94 \\
\hline Diesel, övrig & 33,32 & 5,38 & 0,35 & 39,05 & 34,59 \\
\hline
\end{tabular}

Tabel 48. Drivmedelsskatter (cent/liter) fr.o.m. 1 januari 2008 samt för 2007

En oljeskyddsavgift på o,50 euro/ton tas ut på alla importerade oljeprodukter.

Skatten på fossilgas (1,9 euro/MWh) är lägre än skatten på bensin (64,86 euro/MWh).

16 april 2008 kostade 95-oktanig bensin (inkl moms) i Helsingforsområdet 1,41 euro/liter, diesel 1,25 euro/liter.

För att - i enlighet med EUs biodrivmedelsdirektiv - stimulera användningen av biodrivmedel, är företag som säljer drivmedel skyldiga att se till att en viss andel av drivmedlen (räknat som energimängd) är biodrivmedel. Under 2008 ska andelen vara 2 procent, 20094 procent och från 2010 5,75 procent. Målet för 2008 kommer man att uppnå via låginblandning av etanol i bensin. Användningen av biodrivmedel uppmuntras inte via några skatteundantag. 


\section{Beskatning af køretøj}

\section{Bilskatt (registreringsskatt)}

Bilskatt betalas när bilen registreras. Tills nyligen har bilskatten enbart baserats på bilens beskattningsvärde (det typiska försäljningspriset på bilen), men från 2008 relateras skatten även till bilens certifierade koldioxidutsläpp.

Vid årsskiftet 2007/2008 sänktes den genomsnittliga bilskatten med 1/6 samtidigt som den kopplades till bilens koldioxidutsläpp. Numera beräknas bilskatten enligt följande formel:

\section{Bilskatt $=$ Beskattningsvärde $x($ certifierat koldioxidutsläpp $(\mathrm{g} / \mathrm{km}): 10+4)$}

Skatten är nu som lägst 10 procent av beskattningsvärdet, som högst 40 procent. För fordon utan certifierade koldioxidutsläppsvärden baseras skatten på vikt och är sammantaget något lägre, särskilt för dieselbilar.

I praktiken innebär förändringen att bilskatten höjdes för bilar som drar mera än 9,4 liter bensin respektive 8,5 liter diesel per 100 kilometer.

\begin{tabular}{lccccc} 
Bilmodell & $\begin{array}{c}\mathbf{C O}_{\mathbf{2}} \text {-utsläpp } \\
\mathbf{g / k m}\end{array}$ & $\begin{array}{c}\text { Ny skattesats, } \\
\text { \% av beskatt- } \\
\text { ningsvärde }\end{array}$ & $\begin{array}{c}\text { Tidigare pris, } \\
\text { euro }\end{array}$ & $\begin{array}{c}\text { Beräknat nytt } \\
\text { pris, euro }\end{array}$ & $\begin{array}{c}\text { Beräknad } \\
\text { prisförändring, } \\
\text { euro }\end{array}$ \\
\hline Toyota Corolla & 127 & 16,7 & 24870 & 21336 & -3534 \\
\hline Toyota Corolla & 190 & 23,0 & 25970 & 24943 & -1027 \\
\hline Skoda Octavia & 143 & 18,3 & 27790 & 24340 & -3450 \\
\hline Skoda Octavia & 214 & 25,4 & 34240 & 33878 & -362 \\
\hline Volkswagen Golf & 137 & 17,7 & 29170 & 25274 & -3896 \\
\hline Volkswagen Golf & 259 & 29,9 & 48230 & 51279 & 3049 \\
\hline Ford Focus & 125 & 16,5 & 25370 & 21684 & -3686 \\
\hline Ford Focus & 224 & 26,4 & 38750 & 38862 & 112 \\
\hline Toyota Avensis & 146 & 18,6 & 33100 & 28976 & -4124 \\
\hline Toyota Avensis & 228 & 26,8 & 41450 & 41783 & 333 \\
\hline Volkswagen Passat & 148 & 18,8 & 32160 & 28264 & -3896 \\
\hline Volkswagen Passat & 242 & 28,2 & 52530 & 53984 & 1454 \\
\hline Volvo V70 & 153 & 19,3 & 45300 & 39802 & -5498 \\
\hline Volvo V70 & 272 & 31,2 & 65500 & 70943 & 5443 \\
\hline Mazda 6 & 165 & 20,5 & 31210 & 28203 & -3007 \\
\hline Mazda 6 & 246 & 28,6 & 43600 & 45355 & 1755 \\
\hline Honda CR-V & 173 & 21,3 & 37815 & 34446 & -3369 \\
\hline Honda CR-V & 195 & 23,5 & 53750 & 50795 & -2955 \\
\hline Ford Mondeo & 151 & 19,1 & 33140 & 29238 & -3902 \\
\hline Ford Mondeo & 223 & 26,3 & 38500 & 38550 & 50 \\
\hline
\end{tabular}

Tabel 48. Effekter av förändrad bilskatt på de 20 mest sålda bilmodellerna i Finland, versioner med lägst resp högsta utsläppsvärdena Källa: Regeringens proposition 147/2007 


\begin{tabular}{|c|c|c|c|c|}
\hline Bilmodell & $\begin{array}{l}\text { Listpris, inkl } \\
\text { skatter, euro }\end{array}$ & $\begin{array}{l}\text { Bilskatt/registre- } \\
\text { ringsskatt, euro }\end{array}$ & $\begin{array}{l}\text { Fordonsskatt, } \\
\text { euro/år }\end{array}$ & $\begin{array}{l}\text { Drivmedelskostnad } \\
16000 \mathrm{~km} \text {, euro }\end{array}$ \\
\hline $\begin{array}{l}\text { Citroen Picasso Grand C4 } \\
\text { 2,0 HDI } 138 \text { FAB }\end{array}$ & 36100 & 5607 & 690 & $\begin{array}{l}\text { 1488, varav } 417,87 \\
\text { drivmedelskatt } \\
(1184 \mathrm{l})\end{array}$ \\
\hline Volvo V70 2,5T 20ohk & 46900 & 7372 & 127,5 & $\begin{array}{l}\text { 2110, varav 932,98 } \\
\text { drivmedelskatt } \\
(1488 \mathrm{l})\end{array}$ \\
\hline $\begin{array}{l}\text { Volkswagen 1,4 TDI Polo } \\
\text { 3D 8ohk }\end{array}$ & 15340 & 1790 & 395,5 & $\begin{array}{l}905, \text { varav } 262,08 \\
\text { drivmedelskatt } \\
(720 \mathrm{l})\end{array}$ \\
\hline $\begin{array}{l}\text { Toyota Aygo 1,0 3-d VVT-I } \\
\text { plus }\end{array}$ & 11690 & 1242 & 127,5 & $\begin{array}{l}\text { 1044, varav 461,47 } \\
\text { drivmedelskatt } \\
(736 \text { l) }\end{array}$ \\
\hline Toyota Prius & 29950 & 3090 & 127,5 & $\begin{array}{l}954, \text { varav } 421,34 \\
\text { drivmedelskatt } \\
(672 \text { l) }\end{array}$ \\
\hline $\begin{array}{l}\text { Saab 9-3, biopower 1.8T, } \\
\text { 4-d }\end{array}$ & Finns inte & Finns inte & Finns inte & Finns inte \\
\hline
\end{tabular}

Tabel 49. Priser och skatter på fordon och drivmedel 2008, euro

Mervärdesskatten är 22 procent.

\section{Årlig fordonsskatt}

Fordonsskatt tas ut på alla vägfordon. Skatten beräknas per kalenderdag. Den består dels av en grundskatt som tas ut på alla fordon, dels en drivkraftsskatt som endast tas ut på icke-bensindrivna fordon (bilar som kan köras på gas och uppfyller särskilda avgaskrav är dock undantagna från drivkraftsskatten).

\section{Nuvarande system}

Grundskatten är 35 cent per dag (127,75 euro per år), för bilar som registrerats före 1994 är grundskatten är 26 cent per dag (94,90 euro per år).

Drivkraftsskatten baseras på fordonets vikt. För personbilar är skatten 6,7 cent per dag (motsvarar 24,5 euro per år) och $100 \mathrm{~kg}$. För lätta lastbilar och bussar är motsvarande skatt betydligt lägre - 0,9 cent per dag och $100 \mathrm{~kg}$. För tunga fordon $(\cdots . \cdots 3500 \mathrm{~kg})$ baseras skatten på antalet hjulaxlar.

\section{Framtida system}

Grundskatten kommer att läggas om, troligen 2010. Redan finns ett riksdagsbeslut som tillåter regeringen att radikalt ändra skatten. För fordon med certifierade koldioxidvärden kommer skatten då att helt baseras på detta värde. För övriga fordon ska skatten även fortsättningsvis i allmänhet baseras på vikt (bortsett från vissa mindre lastbilar som även fortsättningsvis ska betala 35 cent per dag). 


\begin{tabular}{lrr}
$\begin{array}{l}\text { Certifierade } \mathrm{CO}_{2} \\
\text {-utsläpp, gram/km }\end{array}$ & cent/dag & euro/år \\
\hline max 66 & 5,3 & 20 \\
\hline 100 & 11,5 & 41,98 \\
\hline 130 & 18,9 & 68,99 \\
\hline 160 & 28 & 102,2 \\
\hline 200 & 43 & 156,95 \\
\hline 230 & 56,4 & 205,86 \\
\hline 260 & 71,5 & 260,98 \\
\hline 300 & 94,5 & 344,93 \\
\hline 330 & 113,9 & 415,74 \\
\hline 360 & 135 & 492,75 \\
\hline 400 or more & 166 & 605,9 \\
\hline
\end{tabular}

Tabel 50. Framtida grundskatt för personbilar (troligen från 2010)

För lätta fordon ( $3500 \mathrm{~kg}$ ) utan certifierade koldioxidutsläppet kommer skatten att baseras på vikt enligt tabel 51.

\section{Totalvikt, kg fordonsskatt, cent/dag fordonsskatt, euro/år}

\begin{tabular}{lll} 
Max 1300 & 20,8 & 75,92 \\
\hline $1301-1400$ & 23,8 & 86,87 \\
\hline $1401-1500$ & 27 & 98,55 \\
\hline $1501-1600$ & 30,4 & 110,96 \\
\hline $1601-1700$ & 34 & 124,1 \\
\hline $1701-1800$ & 37,8 & 137,97 \\
\hline $1801-1900$ & 41,8 & 152,57 \\
\hline $1901-2000$ & 46 & 167,9 \\
\hline $2001-2100$ & 50,4 & 183,96 \\
\hline$\ldots$ & & \\
3401 och högre & 133 & 485,45 \\
\hline
\end{tabular}

Tabel 51. Framtida fordonsskatt personbilar utan certifierade koldioxidutsläpp (troligen från 2010)

Några beslut om att ändra drivkraftsskatten finns inte. 


\section{Andra skatter och skatteregler som berör personbilstrafik}

\section{Avdrag för resa till och från arbetsplats}

Skattebetalare får göra avdrag för resekostnader till och från arbetsplatsen motsvarande billigaste ressätt (normalt buss eller tåg). Finns inte tillgång till kollektivtrafik får avdrag för bilresa göras på o,22 euro/km. Taket för högsta reseavdrag höjdes 2007 till 7000 euro/år. Syftet var att underlätta arbetspendling på långa avstånd.

\section{Förmånsbilar}

Cirka 1/ 4 av de nysålda bilarna köps av företag. Av de 76000 bilar som 2005 var registrerade på företag angavs knappt 57000 vara "fria förmånsbilar", vilket innebär att den som har tillgång till bilen även kan använda den utanför arbetet och att arbetsgivaren även betalar drivmedel.

Arbetsgivaren kan dra av kostnaden för bilförmån - inklusive drivmedelskostnaden - och därmed minska sin skatt. Den avdragsgilla kapitalkostnaden uppgår till 25 procent av bilens värde.

Det beräknade värdet av tillgången till bilförmån adderas till den anställdes inkomst vid beskattningen. Arbetsgivaren betalar sociala skatter och avgifter på denna summa. Den beskattningsbara summan beror på bilens registreringsår och det antagna nybilspriset. Skatten påverkas inte av bilens koldioxidutsläpp.

Beskattningen beror på om arbetsgivaren betalar alla kostnader ("fri bilförmån") eller om den anställde åtminstone betalar drivmedelskostnaden ("förmån att använda bil").

\begin{tabular}{|c|c|c|}
\hline Registreringsår & $\begin{array}{l}\text { Fri bilförmån = arbetsgiva- } \\
\text { ren betalar alla kostnader }\end{array}$ & $\begin{array}{l}\text { Förmån att använda bil = den } \\
\text { anställde betalar åtminstone } \\
\text { drivmedelskostnaden }\end{array}$ \\
\hline $2006-2008$ & $\begin{array}{l}1,4 \% \text { av försäljningspriset + } \\
270 \text { euro/år eller } 18 \mathrm{c} / \mathrm{km}\end{array}$ & $\begin{array}{l}1,4 \% \text { av försäljningspriset + } \\
105 \text { euro/år } 7 \mathrm{c} / \mathrm{km}\end{array}$ \\
\hline före 2003 & $\begin{array}{l}1 \% \text { av försäljningspriset + } \\
300 \text { euro/år eller } 20 \mathrm{c} / \mathrm{km}\end{array}$ & $\begin{array}{l}1 \% \text { av försäljningspriset }+135 \\
\text { euro/år eller } 7 \mathrm{c} / \mathrm{km}\end{array}$ \\
\hline
\end{tabular}

Tabel 52. Det skattepliktiga värdet av bilförmån 2008

Om den privata körsträckan överstiger $18000 \mathrm{~km} /$ år kan det beskattningsbara beloppet sättas högre än enligt tabel 52 .

\section{Trängselavgifter/Vägavgifter}

Inga trängselavgifter, vägtullar eller liknande finns i Finland. En förstudie om att eventuellt införa trängselavgifter i Helsingfors har dock inletts av Kommunikationsministeriet. 


\section{Hvordan styrer skatterne trafikkens miljøbelastning}

Trots att drivmedelsskatterna har varit förhållandevis höga, har de inte lett till minskad vägtrafik.

Jämfört med EU i övrigt är den finländska bilparken förhållandevis gammal och bränsletörstig. Även nyregistrerade bilar drar mycket bränsle och har höga $\mathrm{CO}_{2}$-utsläpp jämfört med övriga EU. En förklaring är frånvaron av utsläppsrelaterade skatter. Förändringen av bilskatten (registreringsskatten) från 1 januari 2008 (sänkning med 1/6 men med $\mathrm{CO}_{2}$-utsläpp som en bas) har lett till en ökad bilförsäljning. Omläggningen har också gynnat dieselbilar. Under de två första månaderna 2008 steg andelen sålda dieselpersonbilar från 1/3 till att för första gången vara större än andelen bensinbilar. Det nya skattesystemet gynnar inte tydligt bilmodeller med lägst utsläpp och har ingen större inverkan på priset på de dyraste och törstigaste modellerna.

På grund av den relativt höga registreringsskatten har importörerna traditionellt tvingats hålla lägre importpriser vid import till Finland än till länder med lägre registreringsskatter. Att registreringsskatten i genomsnitt sänkts med 1/6 har gjort det möjligt för importörerna att höja importpriserna. På så sätt kan konsumentpriserna sänkas samtidigt som bilhandlens vinst ökar. Nya personbilar beräknas idag vara 11 procent billigare än 2002. Priset på begagnade bilar beräknas samtidigt ha sjunkit med 30 procent.

Beskattningen av bilförmån har inte gynnat bilar med låga $\mathrm{CO}_{2}$-utsläpp. Systemet har däremot uppmuntrad förmånstagarna att köra långt. Bilförmån betraktas som ett tillägg till den ordinarie lönen, den betraktas ofta som en statussymbol vilket betyder att stora, motorstarka modeller är överrepresenterade. När arbetsgivaren betalar drivmedlet kan den anställde uppleva att hans eller hennes lön ökar ju mera bilen används. Detta sammantaget anses förklara varför förmånsbilar har större $\mathrm{CO}_{2}$-utsläpp per km än genomsnittet.

Avdraget för resors till och från arbetet stimulerar en utglesning av samhällsstrukturen och driver upp både trafikarbetet och utsläppen. Höjningen av avdragstaket till 7000 euro/år 2007 förstärker dessa effekter ytterligare.

Frånvaron av incitament för användning av biodrivmedel har lett till att den mycket låga användningen av biodrivmedel.

Vid EU-toppmötet i mars 2007 fastställde EU-ledarna ett mål om att Finland och övriga EU-länder till 2020 måste öka andelen förnybara drivmedel till 10 procent. Biogas är det drivmedel som skulle ge den största nettominskningen av $\mathrm{CO}_{2}$-utsläpp. I Finland finns idag endast 200 gasbilar. De drivs nästan enbart med fossilgas. 


\section{Förslag till förändringar av den finländska trafikbeskattningen}

\section{Drivmedel}

I princip bör beskattningen av drivmedel baseras på energiinnehåll. För att bl a uppmuntra övergången till mera bränslesnåla fordon bör skatten på bensin och diesel öka med $40 \mathrm{c} / \mathrm{l}$.

Skatten på biodrivmedel bör slopas. Det måste bli ekonomiskt attraktivt att föra in biogas i gassystemet.

\section{Fordon}

Vid en höjning av drivmedelskatten enligt ovan kan den årliga fordonsskatten avskaffas eftersom den har svag miljönytta.

Bilskatten och fordonsskatten bör reduceras för bl a hybridbilar och bilar som kan utnyttja biodrivmedel (t ex gasbilar och flexifuel-bilar).

\section{Övriga skatter}

Värdet av bilförmån i beskattningen bör bestämmas efter bilens $\mathrm{CO}_{2}$-avsläpp.

Förmån av fri parkering vid arbetsplatsen bör förmånsbeskattas.

Trängselavgifter och vägtullar bör utnyttjas i större städer och på större vägar.

Den skattefria resekostnadsersättning som arbetsgivaren kan ge till anställd som utnyttjar egen bil i arbetet bör sänkas så att den motsvarar de verkliga kostnaderna.

För att öka kollektivtrafikandelen bör mervärdesskatten på biljetter sänkas och stödet för kollektivtrafik höjas, särskilt i de större städerna. Försök med nolltaxa inom kollektivtrafiken bör genomföras. Anslagen för drift, underhåll och investeringar i järnvägssystemet bör höjas. 
DEL II. 6. Island

alle priser her $\mathrm{i}$ islandske kroner

\section{Grundfakta om bilbestand, brændstofforbrug, miljøbelastning mv}

\section{Klimagassutslipp}

Transportsektoren sto for 21 prosent av de nasjonale utslippene i $2005 .{ }^{95}$ Det har vært en økning i utslippene fra denne sektoren på 17 prosent fra 1990 til 2006. Av disse utslippene skyldes rundt 95prosent veitrafikk. Utslippene fra denne sektoren var på nærmest 750 tusen tonn $\mathrm{CO}_{2}$-ekvivalenter i 2006, som vist på figur 17. Men de nasjonale utslippene var på 3,7 millioner tonn i 2005. ${ }^{96}$

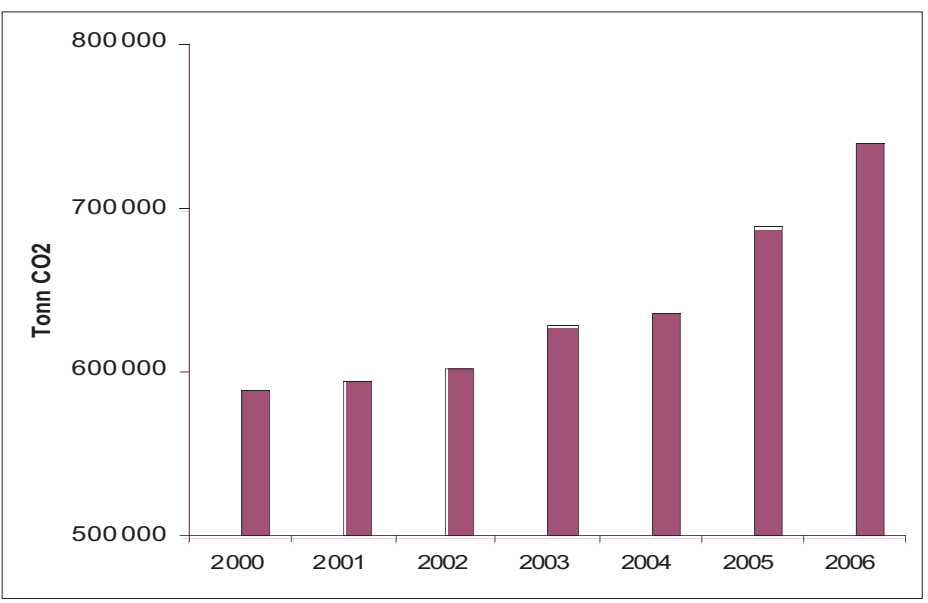

Figur 17. Utslipp fra samferdselssektoren på Island 2000-2006, kilde Sigurdur Ingi Fridleifsson, Orkusetur. ${ }^{97}$

Island har ikke satt seg noen konkrete mål for reduksjoner i klimagassutslipp fra transportsektoren. Men Island har satt seg mål om å redusere utslippene totalt med 50-75 prosent innen 2050, sammenlignet med 1990-nivå. Selv om

95 http://reports.eea.europa. eu/eea_report_2007_5/en/l celand.pdf

96 http://reports.eea.europa. eu/eea_report_2007_5/en/l celand.pdf

97 Kynning. Stefnumót Umhverfisráduneytis og Stofnunar Sæmundar fróda mars 2007, Sjálfbærar samgöngur.

98 http:/www.umhverfisraduneyti.is/media/PDF_skrar/St efnumorkun_i_loftslagsmalum.pdf

99 http://www.os.is/Apps/ WebObjects/Orkustofnun.w oa/swdocument/3804/Eldsn eytissp \% $\mathrm{C}_{3} \% \mathrm{~A}_{1}+2005$ 2030.pdf det ikke er satt noen konkrete mål for reduksjon, er det gjort noen vurderinger angående tiltak som bør i verksettes for å få ned utslippene:

- Motivere til kjøp av "miljøvennlige biler" blant annet gjennom reduserte avgifter på klimavennlige biler som elektriske biler, hydrogenbiler, hybridbiler etc.

- Det offentlige skal gå foran og bruke miljøvennlige biler så langt det lar seg gjøre.

- $\emptyset k t$ informasjon til forbrukere om klimaeffekten av forskjellige biltyper.

- Det offentlige skal legge mer til rette for sykling og kollektivtransport.98

\section{Bilbestanden på Island}

Bilbestanden på Island er preget av jeeper og store bensinbiler. Økningen i personbilbestanden har vært stor de siste årene, og bestanden øker fortsatt. $\emptyset$ kningen har vært 4,2 prosent i gjennomsnitt de siste 10 årene. ${ }^{99}$ | 2007 var 
100 Thórhallur Ásbjörnsson, 2005. http://www.landvernd.is/myndir/BilarOkt2o 05.pdf

101 Hreinn Haraldsson og

fl.,2001. http://vgwww.

vegagerdin.is/vefur2.nsf/Fil

es/skyrslaumlosungrodur-

husalofttegundafrasamgon

gum $/ \$$ file $/ G r \%$ c3\% b3\% c3

$\%$ bourh\% c3\% basa\% c3\%

a1hrif2.pdf

102 WWw. US. is

103 Hreinn Haraldsson og

fl.,2001.

http://vgwww.vegagerdin.is /vefur2.nsf/Files/skyrslaum losungrodurhusaloftte. gundafrasamgongum/\$file/ Gr\% c3\% b3\% c3\% bourh\% c3\% basa\% c3\% a1hrif2.pdf

104 http://www.landvernd.is/ myndir/Stoduskyrsla2005. $p d f$

105 http://www.us.is/page/ oll_okutaeki det registrert 312.872 innbyggere på Island ifølge Hagstofa Islands og 158986 personbiler ifølge Umferdastofa. Av figur 18 framkommer det hvordan bilbestanden har endret seg de siste årene, og den viser en prognose for forventet vekst. ${ }^{100}$ Antall biler på $y$-aksen og år på x-aksen. Personbiltettheten var på 591 per 1000 innbygger i Reykjavik i 2004. I 1999 var andelen dieselbiler av alle biler mindre enn $4000 \mathrm{~kg}$ på 9 prosent.

Hvis en ser på personbilbestanden i 2007, utgjorde bensinbiler 84 prosent og dieselbiler 16 prosent. Det vil si 142714 bensinbiler og 16204 dieselbiler ifølge Umferdastofa. Hvis en ser på solgte biler i 2007, så ble det solgt 10758 bensinbiler og 5007 dieselbiler. Det vil si 32 prosent dieselbiler og 68 prosent bensinbiler. ${ }^{102}$ Det har vært en $\emptyset$ kning $\mathrm{i}$ antall dieselbiler av alle nye biler på Island de siste årene som vist i figur 19. Men fra denne figuren er det også klart at bensinbiler, både store og små, har vært dominerende på Island. Det er ikke noen avgiftsendringer rundt bensin diesel som har bidratt til denne økningen i antall nye dieselbiler, det kan eventuelt skyldes en generell økning i dieselbiler i Europa. I figur 18 er det også vist en prognose for utviklingen av bilbestanden.

Fra 1990 til 1994 økte gjennomsnittbruken per bil per år fra 11400 km til 13 $300 \mathrm{~km}$. I 1999 var så gjennomsnittskjørelengden per personbil på $12200 \mathrm{~km}$. I 2004 var det oppe i $12600 \mathrm{~km} /$ bil. I 1990 var totalkjørelengde på Island på 1,5 milliarder km mot 2,1 milliarder i 1999. Det vil si en økning på 36,6 prosent.

Samtidig var det en økning i bilbestanden på 27 prosent og en befolkningsvekst på 7 prosent. ${ }^{103}$ Det er forventet en økning på om lag 25 prosent i antall kjørte kilometer frea til 2030 ifølge det islandske vegvesenet.

Gjennomsnittsalder for islandske biler var i 20059,8 år. ${ }^{104}$ I 2008 var det registrert 7466 varebiler, der av 870 bensinbiler og 6596 dieselbiler ifølge Umferdastofa $^{105}$. Av nyregistrert varebiler i 2007 var det 9 bensinbiler og 545 dieselbiler.

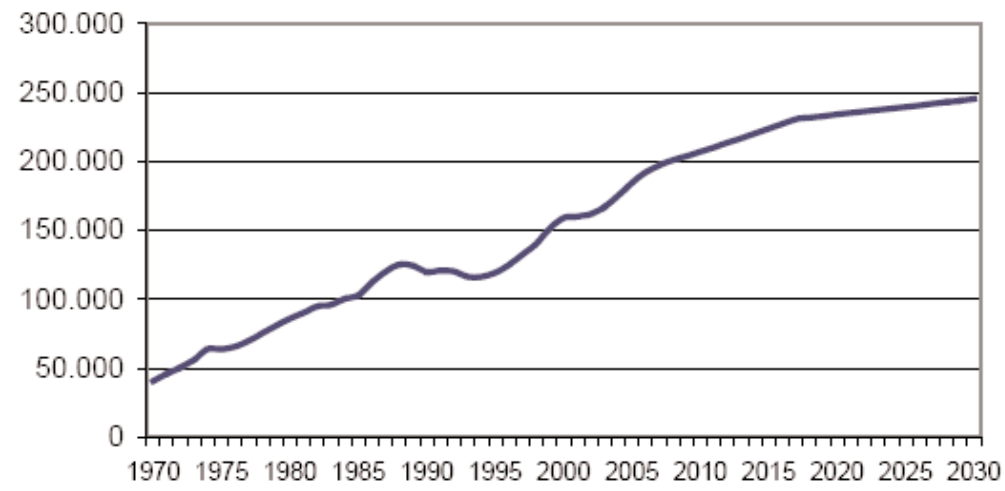

Figur 18. Bilbestanden på Island de siste årene, faktiske tall fram til $20040 \mathrm{~g}$ prognose etter det, kilde Thórhallur Ásbjörnsson, GHL frá einkabílum: Áhrif adgerda til ad draga úr losun, 2005, http://www.landvernd.is/myndir/BilarOkt2005.pdf 
Det er flere enn 300 hybridbiler på Island, hvor Toyota er den mest populære. Det er rundt 100 biler på Island som har gastanker slik at de kan bruke metangass. ${ }^{106}$ Det fantes minst to biler som går på etanol på Island i slutten av 2007, en Ford C-Max 1.8 Flexifuel og en Volvo C30 1.8 Flexifuel.

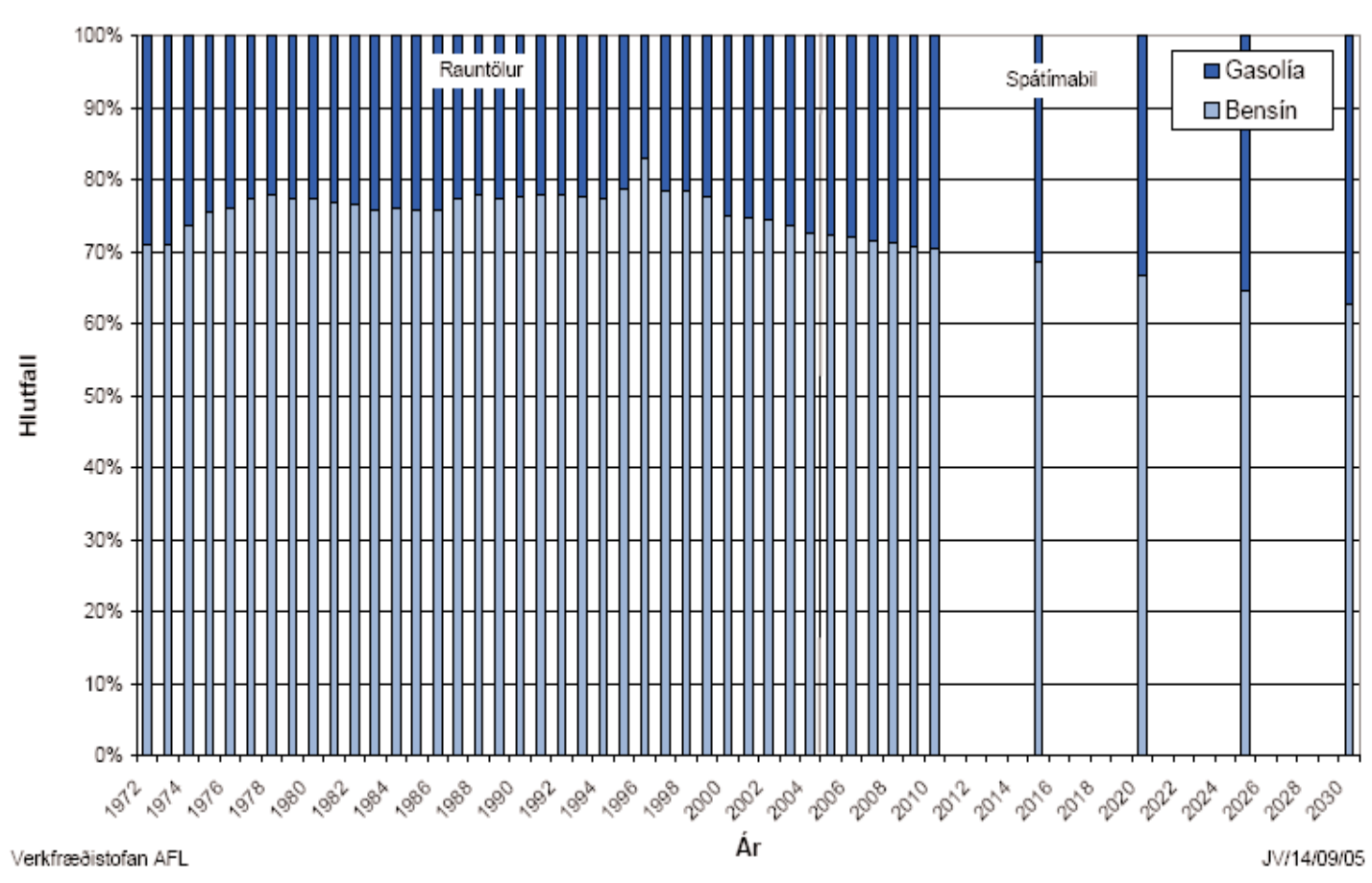

106 http://www.gamli.umhverfissvid.is/Files/Skra_ooo39 71.pdfvoru 43

107 http://www.os.is/Apps/ WebObjects/Orkustofnun.w oa/swdocument $/ 3804 /$ Elds neytissp \% $\mathrm{C}_{3} \% \mathrm{~A}_{1}+2005$ 2030.pdf

108 Haraldur Sigur?sson, 2004. http://www.borg.hi.is/Ferda venjur.pdf

109 Samgönguskipulag í Reykjavík fyrsti hluti greining á stö?u og stefnu, 2006. http://vgwww.vegagerdin.is/vefur2.nsf/Files/S amgskipulag Rvk-stadastefna/\$file/Samgskipulag Rvk-stada-stefna.pdf
Figur 19. Bilbestanden på Island etter drivstofftype, aktuelle tall inn til 2005, prognose etter det. Kilde: Eldsneytisspa 2005-2030, Orkustofnun (gasolia betyr diesel, rauntølur betyr reelle tall, spatimabil betyr interval for prognose). ${ }^{107}$

\section{Reisevaner på Island (Reykjavik)}

Ifølge en rapport fra 2002 utført av Reykjavik kommune utføres 75,4 prosent av alle reiser i Reykjavik med personbil, 19,5 prosent til fots og 4 prosent kollektivt. Men av arbeidsreiser er kun 8 prosent til fots og resten stort sett privatbilen. ${ }^{108}$ En treddel av alle reiser i Reykjavik er kortere enn $1 \mathrm{~km}$, og mer enn 5oprosent er kortere enn 2 km. Ifølge utregninger fra Reykjavik kommune var antall kjørte kilometer i Reykjavik 1,075 milliarder km i 2002.

Gjennomsnittslengde for alle reiser er 3,25 km men 5,04 km for kun bilreiser. Ut ifra modellberegninger kan en se at antall kjørte kilometer per person i Reykjavik var 6000 i $20020 \mathrm{~g}$ den anslås å bli $7600 \mathrm{~km} \mathrm{i} \mathrm{2024.}{ }^{109} \mathrm{Gjennomsnitt}$ reiser folk 4,2 ganger om dagen i Reykjavik. 
110 http://www.os.is/Apps/ WebObjects/Orkustofnun.w oa/swdocument $/ 3804 /$ Elds neytissp \% $\mathrm{C}_{3} \% \mathrm{~A}_{1}+2005$ 2030.pdf

\section{Beskatning af drivmiddel}

Drivstoffforbruk og beskatning på Island

På Island er det mye større forbruk av bensin enn diesel til personbiler. Dette skyldes antageligvis noe kultur for amerikanske biler, men mest at det ikke har vært noen insentiver til å motivere til dieselforbruk. Dieselprisen er høyere enn bensinprisen, hvis en ser på dagens pris, og hvis en tar med at tidligere måtte dieselkjøretøy betale en såkalt, thungaskattur, eller vektavgift. Den var avhengig av hvor mye du kjørte. Forbruk av bensin og diesel til veitrafikk har økt de siste årene fra rundt 150 tusen tonn i 1982 til rundt 270 tusen tonn i 2005. Figur 20 viser utviklingen av bensin- og dieselsalg fra pumpe årene 1970-2002. I 2006 var det fordelingen mellom bensinforbruk og dieselforbruk slik at det ble solgt rundt 225 tusen tonn bensin og rundt 60 tusen tonn diesel. ${ }^{110}$ I tabell 53 bringer vi en oversikt over dagens skatter og avgifter på bensin og diesel.

Mynd 2.13 Bensín og dísilolía, sala frá dælu 1970-2002

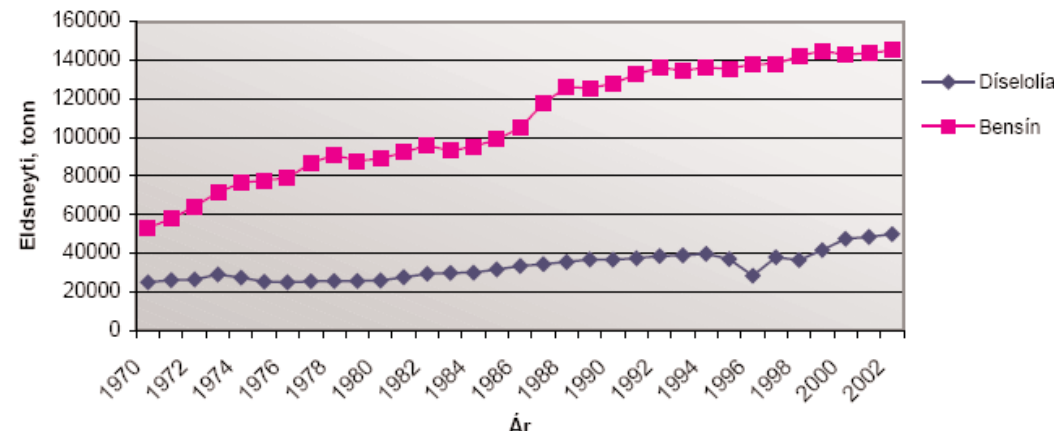

Figur 20 Mengde drivstoff solgt fra bensinstasjoner fra 1970 til 2002. Kilde: Thórhallur Ásbjörnsson, http://www.landvernd.is/myndir/BilarOkt2005.pdf.
Fordeling av utsalgpris

på diesel, Desember 2007
Fordeling av utsalgpris på bensin Februar 2008

\begin{tabular}{lclr} 
Innkjøpspris per liter & $44,73 \mathrm{kr}$ & Innkjøpspris per liter & 42,69 kr \\
\hline Oljeavgift & $41,00 \mathrm{kr}$ & Vareavgift & $9,28 \mathrm{kr}$ \\
\hline $\begin{array}{l}\text { Ekstra avgift } \\
\text { (utjevningsavgift) }\end{array}$ & $0,72 \mathrm{kr}$ & $\begin{array}{l}\text { Ekstra avgift } \\
\text { (utjevningsavgift) }\end{array}$ & $0,36 \mathrm{kr}$ \\
\hline Moms & $27,75 \mathrm{kr}$ & Moms & $27,07 \mathrm{kr}$ \\
\hline Påslag til forhandler & $26,80 \mathrm{kr}$ & Påslag til forhandler & $25,19 \mathrm{kr}$ \\
\hline & & Bensinavgift & $32,95 \mathrm{kr}$ \\
\hline Utsalgspris totalt & $\mathbf{1 4 1 , 0 0 ~ k r}$ & Utsalgspris totalt & $137,54 \mathrm{kr}$ \\
\hline Avgifter totalt & $\mathbf{6 9 , 4 7 ~ k r}$ & Avgifter totalt & $69,66 \mathrm{kr}(50,65 \%)$ \\
\hline
\end{tabular}

Tabell 53. Fordeling av bensin- og dieselprisen på Island. Tall fra Felag islenskra bifreidaeigenda FIB, www.fib.is. 
Det selges etanol ett sted i Reykjavik, og det er ikke avgiftsbelagt slik som tradisjonelt fossilt drivstoff. Det selges også biodiesel og metangass i Reykjavik, og heller ikke det er avgiftsbelagt slik som fossilt drivstoff.

Det er lite detaljert informasjon tilgjengelig angående klimagassutslipp fra bilbestanden. Men det arbeides nå (april 2008) med en mer detaljert oversikt over $\mathrm{CO}_{2}$-utslipp i gram per kilometer fra nye personbiler på Island. Det er Umferdastofa (www.us.is) og Orkusetur (www.orkusetur.is) som nå arbeider med disse dataene på Island. Ifølge en rapport fra 2001 har det vært en tendens at forbruket av både bensin og diesel har gått ned for hver kjørte kilometer de siste årene. Det henger også sammen med mer effektive bilmotorer. Men ifølge rapporten har bensinforbruket per $100 \mathrm{~km}$ blitt redusert fra 12,5 liter til 10,8 liter mellom 1990 og 1999. Det vil si rundt 1,4 prosent i året.

Dieselforbruket per $100 \mathrm{~km}$ er også blitt redusert, fra 29,6 liter per $100 \mathrm{~km}$ til 18,7 liter per $100 \mathrm{~km}$, det vil si rundt 3,7 prosent i året. Utslipp av karbondioksid per kilometer var 350 gram i gjennomsnitt i 1990, men redusert til 290 gram i 1999. Fra figur 21 ser vi at det har vært redusert forbruk per $100 \mathrm{~km}$ de siste årene. På figuren er det forbruk i liter per $100 \mathrm{~km}$ på y-aksen. Dette skyldes i hovedsak mer effektive motorer, men noe av dette er blitt spist opp av større biler.

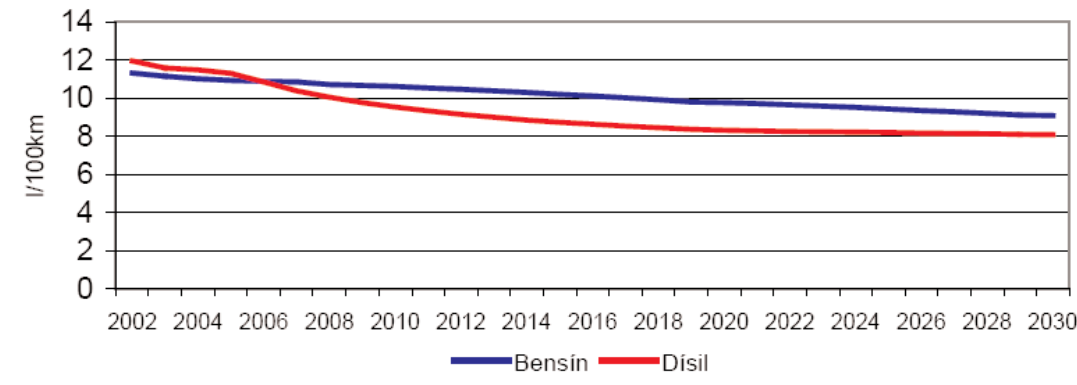

Figur 21. Forbruk av drivstoff liter per $100 \mathrm{~km}$ for gjennomsnittsbilen på Island, både bensin og diesel, tall for 2002 til 20040 grognose etter det. Kilde: Thórhallur Ásbjörnsson, http://www.landvernd.is/myndir/BilarOkt2005.pdf. 


\section{Beskatning af køretøj}

Alle biler som blir importert, ilegges moms på 24,5 prosent. I tillegg betales det en såkalt vareavgift som er avhengig av størrelse på bilen. Mindre biler betaler 30 prosent vareavgift, men større biler ilegges 45 prosent vareavgift. Varebiler betaler 13 prosent avgift. Alle biler må betale 1500 kr i “farlig avfall”avgift. Ifølge tollvesenet må det for biler med motor som er større enn 2000 $\mathrm{cm}^{3}$, betales 45 prosent, mens det må betales 30 prosent for biler som har en motor som er mindre. ${ }^{111}$ Denne avgiften settes direkte på innkjøpsprisen hos forhandler. For elektriske biler, metanbiler og hydrogenbiler betales det en redusert avgift, dvs. at det er en rabatt på 240000 kr. Men det er ennå ikke avklart hva slags avgift blir på andre biodrivstoffbiler.

I tillegg til vareavgiften så betaler bileiere en såkalt bilavgift hvert år. Denne avgiften er avhengig av vekten på bilen. Biler som betaler bilavgift defineres slik:

- Alle kjøretøy som brukes til transport av mennesker eller varer og er tyngre enn $400 \mathrm{~kg}$ og kan kjøre fortere en $30 \mathrm{~km} /$ timen.

- Bilavgiften er ikke avhengig av drivstoff type og omhandler alle typer drivstoff. Det er ikke unntak for eksempel for elektriske biler.

Fra 1. januar 2002 defineres summen slik at for første $1000 \mathrm{~kg}$ betaler man 6,6 kroner, for de neste $2000 \mathrm{~kg}$ betaler man 8,9 kroner og for hvert startet tonn over $3000 \mathrm{~kg}$ betaler man 2200. Avgiften er uansett aldri mindre enn $3300 \mathrm{kr}$ og aldri høyere en 39800 kr. ${ }^{112}$.

\section{Generelt om miljø, trafikkskatter og avgifter på Island}

På Island har det tradisjonelt vært lite fokus på å redusere veitrafikken. De skattene som legges på drivstoff, defineres ikke som miljøskatter, men som veiskatter. For noen år tilbake ble det gjort en avgiftsendring slik at store pick-upbensinbiler ble definerte som varebiler og fikk 13 prosent avgift istedenfor 45 prosent slik som før. Målsetningen var å bistå f.eks bønder som trengte en slik bil til arbeidsformål. Dessverre ble det en stor generell økning i innkjøp av slike biler til privatbruk.

Veiavgifter har eksitert kun for den største tunnelen på Island, Hvalfjardargøng. Der må alle betale for å komme gjennom. Det er ingen bomring eller andre prisinsentiver for å redusere trafikken i Reykjavik.

111 http://tollur.is/displayer. asp?cat_id=204\&module_id $=210$ \&element id $=5267$ 112 http://www.sp.is/spportal/ Template2. aspx?tabid $=141$
Elektriske biler kan parkere gratis i Reykjavik, og det er nylig (2008) i gangsatt et prosjekt hvor elektriske biler også kan få gratis påfyll i sentrum. Det er flere busser som går på alternativt brensel (hydrogen og metan). Det skjer mye rundt alternativt drivstoff på Island, men det har ikke vært spesielt stort fokus på å redusere biltrafikken generelt. 
DK-Bilag 1.

Grøn ejerafgift, halvårlig betaling for

A. Benzindrevne personbiler, B. Dieseldrevne personbiler mv.

Afgiftssatser

$20070 g 2008$

A. Benzindrevne personbiler mv.

Afgift pr. halvår, kr. pr. personbil

\begin{tabular}{|c|c|c|c|c|}
\hline \multicolumn{3}{|c|}{ Kilometer pr. liter mindst } & \multirow{2}{*}{$\begin{array}{l}20,0 \\
18,2\end{array}$} & \multirow{2}{*}{$\begin{array}{l}260 \\
510\end{array}$} \\
\hline Under & 20,0 & men ikke under & & \\
\hline Under & 18,2 & men ikke under & 16,7 & 760 \\
\hline Under & 16,7 & men ikke under & 15,4 & 1.010 \\
\hline Under & 15,4 & men ikke under & 14,3 & 1.260 \\
\hline Under & 14,3 & men ikke under & 13,3 & 1.510 \\
\hline Under & 13,3 & men ikke under & 12,5 & 1.750 \\
\hline Under & 12,5 & men ikke under & 11,8 & 2.000 \\
\hline Under & 11,8 & men ikke under & 11,1 & 2.250 \\
\hline Under & 11,1 & men ikke under & 10,5 & 2.500 \\
\hline Under & 10,5 & men ikke under & 10,0 & 2.750 \\
\hline Under & 10,0 & men ikke under & 9,1 & 3.240 \\
\hline Under & 9,1 & men ikke under & 8,3 & 3.750 \\
\hline Under & 8,3 & men ikke under & 7,7 & 4.250 \\
\hline Under & 7,7 & men ikke under & 7,1 & 4.740 \\
\hline Under & 7,1 & men ikke under & 6,7 & 5.240 \\
\hline Under & 6,7 & men ikke under & 6,3 & 5.740 \\
\hline Under & 6,3 & men ikke under & 5,9 & 6.230 \\
\hline Under & 5,9 & men ikke under & 5,6 & 6.730 \\
\hline Under & 5,6 & men ikke under & 5,3 & 7.240 \\
\hline Under & 5,3 & men ikke under & 5,0 & 7.740 \\
\hline Under & 5,0 & men ikke under & 4,8 & 8.230 \\
\hline Under & 4,8 & men ikke under & 4,5 & 8.730 \\
\hline Under & 4,5 & & & 9.230 \\
\hline
\end{tabular}


B. Dieseldrevne personbiler mv.

Afgift pr. halvår, kr. pr. personbil

\begin{tabular}{lllll}
\hline Kilometer pr. liter mindst & 32,1 & 80 \\
\hline Under & 32,1 & men ikke under & 28,1 & 370 \\
\hline Under & 28,1 & men ikke under & 25,0 & 660 \\
\hline Under & 25,0 & men ikke under & 22,5 & 980 \\
\hline Under & 22,5 & men ikke under & 20,5 & 1.300 \\
\hline Under & 20,5 & men ikke under & 18,8 & 1.610 \\
\hline Under & 18,8 & men ikke under & 17,3 & 1.930 \\
\hline Under & 17,3 & men ikke under & 16,1 & 2.250 \\
\hline Under & 16,1 & men ikke under & 15,0 & 2.570 \\
\hline Under & 15,0 & men ikke under & 14,1 & 2.890 \\
\hline Under & 14,1 & men ikke under & 13,2 & 3.210 \\
\hline Under & 13,2 & men ikke under & 12,5 & 3.540 \\
\hline Under & 12,5 & men ikke under & 11,9 & 3.860 \\
\hline Under & 11,9 & men ikke under & 11,3 & 4.170 \\
\hline Under & 11,3 & men ikke under & 10,2 & 4.810 \\
\hline Under & 10,2 & men ikke under & 9,4 & 5.460 \\
\hline Under & 9,4 & men ikke under & 8,7 & 6.090 \\
\hline Under & 8,7 & men ikke under & 8,1 & 6.740 \\
\hline Under & 8,1 & men ikke under & 7,5 & 7.350 \\
\hline Under & 7,5 & men ikke under & 7,0 & 7.990 \\
\hline Under & 7,0 & men ikke under & 6,6 & 8.640 \\
\hline Under & 6,6 & men ikke under & 6,2 & 9.270 \\
\hline Under & 6,2 & men ikke under & 5,9 & 9.910 \\
\hline Under & 5,9 & men ikke under & 5,6 & 10.570 \\
\hline Under & 5,6 & men ikke under & 5,4 & 11.200 \\
\hline Under & 5,4 & men ikke under & 5,1 & 11.890 \\
\hline Under & 5,1 & & 12.530 & \\
\hline
\end{tabular}




\section{DEL III: Sammenligninger mellem de nordiske lande}

\section{DEL III. 0. Indledning}

De hidtidige udviklinger og forventningerne til fremtiden for udledning af $\mathrm{CO}_{2}$ fra vejtrafikken i landene er ganske forskellige. Men opgjort som $\mathrm{CO}_{2}$-udledning pr 1000 indbyggere er forskellene ikke så store i dag. Man kan hæfte sig ved, at det geografisk største land, Sverige, har den mindste $\mathrm{CO}_{2}$-udledning $\mathrm{pr}$ 1000 indbyggere. Der er relativt mange og store biler i Sverige, men transportomfanget (og $\mathrm{CO}_{2}$-emissionerne) er ikke større end i de øvrige nordiske lande. Dermed må det antages, at andre forhold end landenes størrelse har større betydning for landenes transportomfang og -forurening. Det kan være afgifter, velstand, konjunkturer mv.

\begin{tabular}{|c|c|c|c|c|c|c|c|}
\hline $\begin{array}{l}\text { ktons } \mathrm{CO}_{2} \text {-æk- } \\
\text { vivalenter pr år }\end{array}$ & 1990 & $2005 / 06$ * & $\begin{array}{r}\text { Stigning } \\
1990-05 / 06\end{array}$ & $\begin{array}{r}2005 / 06 \\
\text {-niveau pr } 1000 \\
\text { indbyggere (tons) }\end{array}$ & 2020 & $\begin{array}{r}\text { Stigning } \\
2005 / 06- \\
2020\end{array}$ & $\begin{array}{r}\text { *Konkret } \\
\text { år for } \\
\text { status }\end{array}$ \\
\hline Danmark & 9.250 & 12.157 & $31 \%$ & 2,22 & & ** $16 \%$ & 2005 \\
\hline Finland & 10.900 & 12.000 & $10 \%$ & 2,30 & 12.800 & $7 \%$ & 2005 \\
\hline Island & 640 & 750 & $17 \%$ & 2,40 & & & 2006 \\
\hline Norge & 7.952 & 10.100 & $27 \%$ & 2,18 & 14.140 & $40 \%$ & 2006 \\
\hline Sverige & 16.829 & 18.675 & $11 \%$ & 2,10 & 20.169 & $8 \%$ & 2005 \\
\hline
\end{tabular}

Tabel 54. Vejtrafikkens $\mathrm{CO}_{2}$-emission i landene (inkl. lastbiler, busser mv.), kilder i landeafsnit, del I.

* Det har ikke været muligt at skaffe tal fra 2006 fra alle lande, derfor er anført 2005 for flere af landene.

** Infrastrukturkommissionens prognose frem til 2015 forudser $10 \%$ stigning i $\mathrm{CO}_{2}$-emission.

Prognoserne for de kommende 12-15 år må tages med forbehold, idet de afspejler varierende grader af passiv fremskrivning og mål-tænkning. Ingen af prognoserne lever op til klimamålene. Så alle landene bør se på udviklingen med "klima-øjne”. Det gælder for Norge i endnu højere grad end de øvrige lande.

Af hensyn til sammenligneligheden er der omregnet til samme valuta, danske kroner. Kursen er pr 11.3.2008. Det vil sige, at så mange danske kr. skal betales for at få 100:

\section{$\begin{array}{llll}\text { Norske kr. } & \text { Svenske kr. } \quad \text { EURO (Finland) Islandske kr. }\end{array}$}

$\begin{array}{llll}94,64 & 79,52 & 745,67 & 7,1234\end{array}$




\begin{tabular}{|c|c|c|c|}
\hline dkr. & Køb af bil & Eje af bil & Drivmiddel, afgift pr liter *) \\
\hline Danmark & $\begin{array}{l}\text { Registreringsafgift. } \\
\text { Typisk } 25-60 \% \text { af bilpris. En } \\
\text { række tillæg og fradrag. Pris } \\
\text { og energiforbrug bestem- } \\
\text { mer } \%\end{array}$ & $\begin{array}{l}\text { Grøn ejerafgift efter energi- } \\
\text { forbrug. } \\
\text { Benzinbiler: } 260-9.230 \\
\text { kr./år Dieselbiler: } 80-12.530 \\
\text { kr./år }\end{array}$ & 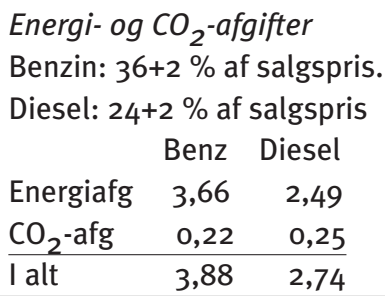 \\
\hline Finland & $\begin{array}{l}\text { Typisk } 15-30 \% \text { af bilpris. } \\
\mathrm{CO}_{2} \text {-afhængig fra } 1.1 .08\end{array}$ & $\begin{array}{l}\text { I dag: Fastdel+vægtdel } \\
\text { Fra 2010: CO2-del + vægtdel }\end{array}$ & $\begin{array}{cr}\text { Benzin } & \text { Diesel } \\
4,66 & 2,71 \\
\end{array}$ \\
\hline Island & $\begin{array}{l}\text { Vareafgift. } 20 / 27 \% \text { af fuld } \\
\text { pris, } 30 / 45 \% \text { af forhandler- } \\
\text { pris for små/store biler, } \\
\text { under/over } 2000 \mathrm{cc}\end{array}$ & $\begin{array}{l}235-2.835 \text { kr. pr år afhængig } \\
\text { af vægt }\end{array}$ & $\begin{array}{cc}\text { Benzin } & \text { Diesel } \\
3,03 & 2,97\end{array}$ \\
\hline Norge & $\begin{array}{l}\text { Engangsafgift. } \\
\text { Typisk } 11-67 \% \text { af bilpris, } \\
\text { grundlag: } \\
\text { egenvægt+effekt+ } \mathrm{CO}_{2} \\
\text { Omregistreringsafgift } \\
7-20.000 \text { efter vægt }\end{array}$ & $\begin{array}{l}\text { Årsafgift } \\
\text { Benzin: } 2.517 \mathrm{kr} \\
\text { Diesel uden partikel-filter: } \\
2.924 \mathrm{kr}\end{array}$ & $\begin{array}{lrl} & \text { Benz } & \text { Diesel } \\
\text { Drivm.skat } & 4,05 & 3,17 \\
\mathrm{CO}_{2} \text {-afgift } & 0,78 & 0,52 \\
\text { I alt } & 4,83 & 3,69\end{array}$ \\
\hline Sverige & $0 \quad \star \star *)$ & $\begin{array}{l}\text { Årlig afgift } \\
\text { - 2005-modeller og ældre } \\
\text { efter vægt } \\
\text { - 2006-modeller og yngre } \\
\text { efter } \mathrm{CO}_{2} \text {-udslip }\end{array}$ & $\begin{array}{lrl} & \text { Benz } & \text { Diesel } \\
\text { Energiskat } & 2,35 & 1,02 \\
\mathrm{CO}_{2} \text {-afgift } & 1,86 & 2,29 \\
\text { I alt } & 4,21 & 3,31\end{array}$ \\
\hline
\end{tabular}

Tabel 55. Afgifts- og skatteregler i de nordiske lande, hovedtræk, personbiler, danske kroner, *) blyfri

Detaljer og undtagelser samt forhold for varebiler beskrives i de enkelte landes afsnit.

**) 1995-2000 afvikledes "bilaccisen"(registreringsafgift) i Sverige, som dog var beskeden på 3-5 \% af salgspris

Generelt er der store forskelle og gennem årene mange ændringer i afgifter på biltrafik i de nordiske lande. Ved køb af bil er de største afgifter og den største variation for biler i Danmark og Norge. Både i Norge og Danmark har nyligt indførte større differentieringer i satser medført, at en større andel af nybilsalget er overgået til mindre biler og dieselbiler. Tilsvarende udvikling ser ud til at være på vej i Finland. 


\begin{tabular}{|c|c|c|c|c|}
\hline & Bilkøb & Eje af bil & Drivmiddel & Andet \\
\hline Danmark & $\begin{array}{l}\text { Registreringsafgift } \\
\text { Elbiler: o kr. indtil } 2012\end{array}$ & $\begin{array}{l}\text { Grøn ejerafgift } \\
\text { reduceret }\end{array}$ & $\begin{array}{l}\text { Normale afgifter på } \\
\text { strøm }\end{array}$ & $\begin{array}{l}\text { Normal afgift } \\
\text { Elbil: - P-afgift i } \\
\text { København }\end{array}$ \\
\hline Finland & - & - & - & - \\
\hline Island & $\begin{array}{l}\text { El-, metan-, og hydro-genbi- } \\
\text { ler: -17.096 kr registrerings- } \\
\text { afgift }\end{array}$ & & & \\
\hline Norge & $\begin{array}{l}\text { Engangsafgift } \\
\text { Elbiler: o } \\
\text { Ethanolbil: }-9.464 \mathrm{kr} \\
\text { Hybrid: -10\% for vægt } \\
\text { Omregistreringsafgift } \\
\text { Elbiler: o }\end{array}$ & $\begin{array}{l}\text { Årsafgift } \\
\text { Erhvervsbiler + } \\
\text { elbiler: }-350 \mathrm{kr} \text {. } \\
\text { Lavere afgifter }\end{array}$ & & $\begin{array}{l}\text { Elbiler fritaget for } \\
\text { P-afgift og bom- } \\
\text { penge }\end{array}$ \\
\hline Sverige & $\begin{array}{l}\text { o. } \\
\text { "Miljøbiler" gives miljø- } \\
\text { præmie på } 7.952 \text { kr }\end{array}$ & & $\begin{array}{l}\text { Helt fritaget for } \\
\text { punktskatter }\end{array}$ & \\
\hline
\end{tabular}

Tabel 56. Hovedtræk af afgifts- og skatteregler i de nordiske lande. Biler med alternative drivmidler, Danske kroner.

Momssatserne er ikke særligt forskellige i de nordiske lande, se tabel 57. Derfor er det ikke betænkeligt at se bort fra disse afgifter i denne rapports sammenligninger. Der kan ikke være væsentlige forskelle i landenes borgeres muligheder for at købe de store forbrugsgoder, biler, af denne grund. Men det er ikke ensartet, hvad der betales moms af.

\begin{tabular}{|c|c|c|c|}
\hline$\%$ & Moms & & \\
\hline Janmark & 25 & \multirow{3}{*}{\multicolumn{2}{|c|}{$\begin{array}{l}\text { Danmark: Ved bilkøb betales } 25 \% \text { af forhandlerens pris } \\
\text { uden afgifter. Drivmiddel: også moms på ener- } \\
\text { gi- og } \mathrm{CO}_{2} \text {-afgifter }\end{array}$}} \\
\hline Finland & 22 & & \\
\hline sland & 24,5 & & \\
\hline Norge & 25 & & $\begin{array}{l}\text { I Norge betales moms også af afgifter både } \\
\text { ved køb af bil og drivmiddel }\end{array}$ \\
\hline verige & 25 & Sverige: & $\begin{array}{l}\text { I Sverige lægges moms både på skatterne ved } \\
\text { køb af bil og drivmiddel }\end{array}$ \\
\hline
\end{tabular}

Tabel 57. Moms ved køb af bil og drivmiddel, 2008

\begin{tabular}{lrrr} 
Mt $\mathrm{CO}_{\mathbf{2}}$ pr år & $\mathbf{1 9 9 0}$ & 2004/05 & \multicolumn{2}{c}{$\begin{array}{r}\text { Cirka-andel af samlet } \\
\text { vejtransports } \mathbf{C O}_{\mathbf{2}} \text {-udslip }\end{array}$} \\
\hline Danmark, 2004 & & 6,6 & $55 \%$ \\
\hline Norge, 1990, 2005 & 4,8 & 5,1 & $50 \%$ \\
\hline Sverige, 2004 & & 12,5 & $70 \%$ \\
\hline
\end{tabular}

Tabel 57a, $\mathrm{CO}_{2}$-udslip fra personbiler. Kilde: Danmark: Miljøstyrelsen, 2007, "Omkostningseffektive tiltag i de ikke-kvotebelagte sektorer", arbejdsrapport nr 22. Norge: Statistisk sentralbyrå, 2007, "Klimagassutslippene ned o,8 prosent", 11. mai 2007. Sverige: Statistiska Centralbyrån , 2005, "CO2-utsläpp til luft- påverkansfaktorer för den svenska bilparken" 
I denne rapport behandles person- og varebilers klimapåvirkning. Nogle data, bl.a. for visse effekter, er kun tilgængelige for den samlede vejtrafik, og en del data er ikke tilgængelige for varebilerne alene. I klimasammenhæng er den samlede effekt interessant. I relation til mulige tiltag til begrænsning af de skadelige påvirkninger er de forskellige bidrag, deres effekt også interessante. Personbilerne dækker mellem 50 og $70 \%$ af vejtrafikkens samlede $\mathrm{CO}_{2}$-udslip, se tabel 57a. Dvs. at varebiler, busser, lastbiler mv. står for 30-50 \%.

Personbilernes store andel af trafikkens samlede $\mathrm{CO}_{2}$-udledning retfærdiggør en særlig fokus på dem, men vare- og lastbilers bidrag bør ikke overses.

Vi anser ovennævnte tal for usikre og finder det ikke godtgjort, at personbilerne står for en så meget større andel af transportens $\mathrm{CO}_{2}$-udledning i Sverige end i Norge og Danmark. Derfor har vi ikke fundet det muligt at lave en konsekvent opdeling mellem personbiler og andre køretøjer i rapporten, men har i en del tilfælde valgt alene at se på personbiler, i andre tilfælde på transporten som helhed. 


\section{DEL III: 1. Priser på udvalgte person- og varebiler}

I dette afsnit ses på priser på typiske bilmærker i de nordiske lande. Der opregnes salgspris, diverse afgifter samt udgifter til brændstof $i$ et år.

Bilpriser: Udsalgspris = listepris. Priserne er endelige priser, dvs. inklusiv levering (herunder nummerplader), inklusiv tillæg og fradrag i registreringsafgift mv.

Drivmiddel. Der opgøres udgift til 20.000 km kørsel på et år. Diesel eller 95 oktan benzin. Brændstofudgiften er beregnet ud fra udsalgsprisen 1.4.2008 og er f eks i Danmark på 10,20 kr. pr/l benzin og 9,50 kr. pr/l diesel ifølge www.hvorlangtpaaliteren.dk.

\begin{tabular}{|c|c|c|c|c|c|}
\hline \multirow[b]{2}{*}{$\mathbf{d k r}$} & \multirow[b]{2}{*}{ Udsalgspris } & \multirow[b]{2}{*}{ Registreringsafgift } & \multirow[b]{2}{*}{ Arlig afgift } & \multicolumn{2}{|c|}{ Drivmiddeludgift 1 år } \\
\hline & & & & I alt & Heraf skatter \\
\hline Danmark & $394 \cdot 570$ & 219.220 & 6.420 & 12.593 & 4.050 \\
\hline Finland & 269.187 & 41.810 & 5.145 & 13.870 & 6.261 \\
\hline Island & 248.607 & $30 \%$ & 1.758 & 18.222 & 8.400 \\
\hline Norge & 413.387 & 131.928 & 2.517 & 14.117 & 4.679 \\
\hline Sverige & 219.078 & 0 & 3.512 & 13.136 & 3.834 \\
\hline
\end{tabular}

1. Stor dieselbil: Citroen Picasso 2007, Grand C4, 2,0 HDI 138 , vtr+, fab med automat gear, ikke EGG, slagvolumen $1997 \mathrm{~cm}^{3}$, 13,5 km/l, *)

\begin{tabular}{|c|c|c|c|c|c|}
\hline \multirow[b]{2}{*}{ dkr } & \multirow[b]{2}{*}{ Udsalgspris } & \multirow[b]{2}{*}{ Registreringsafgift } & \multirow[b]{2}{*}{ Arlig afgift } & \multicolumn{2}{|c|}{ Drivmiddeludgift 1 år } \\
\hline & & & & I alt & Heraf skatter \\
\hline Danmark & 568.178 & 334.894 & 5.000 & 18.889 & 5.746 \\
\hline Finland & 349.719 & 54.971 & 951 & 19.668 & 11.978 \\
\hline Island & 372.554 & $45 \%$ & 1.859 & 21.492 & 10.424 \\
\hline Norge & 574.276 & 383.981 & 2.517 & 23.877 & 9.750 \\
\hline Sverige & 226.552 & 0 & 1.746 & 18.473 & 7.434 \\
\hline
\end{tabular}

2. Stor benzinbil: Volvo $\mathrm{V}_{70}, 2007,2.5 \mathrm{~T}, 147 \mathrm{~kW}$, uden automatgear, slagvolumen $2531 \mathrm{~cm}^{3}, 10,8 \mathrm{~km} / \mathrm{l}$

\begin{tabular}{|c|c|c|c|c|c|}
\hline \multirow[b]{2}{*}{ dkr } & \multirow[b]{2}{*}{ Udsalgspris } & \multirow[b]{2}{*}{ Registreringsafgift } & \multirow[b]{2}{*}{ Arlig afgift } & \multicolumn{2}{|c|}{ Drivmiddeludgift 1 år } \\
\hline & & & & I alt & Heraf skatter \\
\hline Danmark & 194.559 & 84.547 & 2.600 & 8.558 & 2.463 \\
\hline Finland & 114.385 & 13.347 & 2.949 & 8.434 & 3.974 \\
\hline Island & 150.304 & $30 \%$ & 1.140 & $15 \cdot 522$ & 7.156 \\
\hline Norge & 196.899 & 68.643 & 2.517 & 9.175 & 2.842 \\
\hline Sverige & 132.083 & 0 & 902 & 8.398 & 2.451 \\
\hline
\end{tabular}

3. Lille dieselbil: Volkswagen 1.4 TDI, 2008, Polo, 3D, 8o hk, slagvolumen 1422 $\mathrm{cm}^{3}, 51 \mathrm{~kW}, 22,2 \mathrm{~km}$ pr I 


\begin{tabular}{|c|c|c|c|c|c|}
\hline \multirow[b]{2}{*}{ dkr } & \multirow[b]{2}{*}{ Udsalgspris } & \multirow[b]{2}{*}{ Registreringsafgift } & \multirow[b]{2}{*}{ Arlig afgift } & \multicolumn{2}{|c|}{ Drivmiddeludgift 1 år } \\
\hline & & & & I alt & Heraf skatter \\
\hline Danmark & 115.560 & 31.284 & 520 & 8.756 & 2.860 \\
\hline Finland & 87.169 & 9.261 & 951 & 9.731 & $5 \cdot 928$ \\
\hline Island & 121.810 & $30 \%$ & 828 & 9.693 & 4.701 \\
\hline Norge & 137.417 & 34.645 & 2.517 & 10.874 & 4.696 \\
\hline Sverige & 75.862 & 0 & 394 & 9.138 & 3.675 \\
\hline
\end{tabular}

4. Lille benzinbil: Toyota Aygo 1,0 3-d, VVT-I plus, rød, ikke automatgear, slagvolumen $998 \mathrm{~cm}^{3}, 50 \mathrm{~kW}, 21,7 \mathrm{~km}$ pr l

\begin{tabular}{|c|c|c|c|c|c|}
\hline \multirow[b]{2}{*}{ dkr } & \multirow[b]{2}{*}{ Udsalgspris } & \multirow[b]{2}{*}{ Registreringsafgift } & \multirow[b]{2}{*}{ Arlig afgift } & \multicolumn{2}{|c|}{ Drivmiddeludgift 1 år } \\
\hline & & & & I alt & Heraf skatter \\
\hline Danmark & 392.487 & 210.800 & 520 & 8.155 & 2.663 \\
\hline Finland & 223.328 & 23.041 & 951 & 8.896 & 5.525 \\
\hline Island & 248.607 & $30 \%$ & 1.416 & 9.061 & $4 \cdot 394$ \\
\hline Norge & 287.043 & 52.176 & 2.517 & 8.707 & 2.555 \\
\hline Sverige & 217.487 & 0 & 334 & 8.541 & 3.437 \\
\hline
\end{tabular}

5. Hybrid: Toyota Prius 2007, 1,5 aut, benzin, slagvolumen $1497 \mathrm{~cm}^{3}, 57 \mathrm{~kW}$, $23,3 \mathrm{~km}$ pr liter (50 \% km på el, $50 \%$ på benzin)

\begin{tabular}{|c|c|c|c|c|c|}
\hline \multirow[b]{2}{*}{ dkr } & \multirow[b]{2}{*}{ Udsalgspris } & \multirow[b]{2}{*}{ Registreringsafgift } & \multirow[b]{2}{*}{ Arlig afgift } & \multicolumn{2}{|c|}{ Drivmiddeludgift 1 år } \\
\hline & & & & I alt & Heraf skatter \\
\hline Danmark & 386.046 & $215 \cdot 333$ & 3.500 & *) 16.063 & 4.887 \\
\hline Finland & Sælges ikke & & & Sælges ikke & \\
\hline \multicolumn{6}{|l|}{ Island } \\
\hline Norge & 343.732 & 140.100 & 2.517 & & \\
\hline Sverige & 192.359 & 0 & 907 & 14.108 & 1.345 \\
\hline
\end{tabular}

6. Ethanol: Saab 93, 1.8T, biopower / benzin (E85 dvs. $85 \%$ biobrændstof), uden automatgear, 4-d, Bio: 9,3 km pr l, Benzin 12,7 km pr l

\begin{tabular}{|c|c|c|c|c|c|}
\hline \multirow[b]{2}{*}{ dkr } & \multirow[b]{2}{*}{ Udsalgspris } & \multirow[b]{2}{*}{ Registreringsafgift } & \multirow[b]{2}{*}{ Arlig afgift } & \multicolumn{2}{|c|}{ Drivmiddeludgift 1 år } \\
\hline & & & & I alt & Heraf skatter \\
\hline Danmark & 260.159 & 49.414 & 7.080 & 14.615 & 3.074 \\
\hline \multicolumn{6}{|l|}{ Finland } \\
\hline Island & 255.730 & $13 \%$ & 2.099 & $17 \cdot 322$ & 7.985 \\
\hline Norge & 261.282 & 76.753 & 360 & 18.351 & 5.684 \\
\hline Sverige & 216.374 & 0 & 2.285 & 14.504 & 5.028 \\
\hline
\end{tabular}

7. Varebil 1 diesel, Volkswagen Transporter combi 2008, 8 pers, 1,9 liter, 4 cyl, Dieselpartikelfilter, $75 \mathrm{~kW}$, slagvolumen $1896 \mathrm{~cm}^{3}, 13 \mathrm{~km} / \mathrm{l}$ 


\begin{tabular}{|c|c|c|c|c|c|}
\hline \multirow[b]{2}{*}{ dkr } & \multirow[b]{2}{*}{ Udsalgspris } & \multirow[b]{2}{*}{ Registreringsafgift } & \multirow[b]{2}{*}{ Arlig afgift } & \multicolumn{2}{|c|}{ Drivmiddeludgift 1 år } \\
\hline & & & & I alt & Heraf skatter \\
\hline Danmark & 329.070 & 158.477 & 5.000 & 18.545 & 5.642 \\
\hline \multicolumn{6}{|l|}{ Finland } \\
\hline Island & 241.483 & $30 \%$ & 1.777 & 19.175 & $9 \cdot 300$ \\
\hline Norge & 383.197 & 213.194 & 2.517 & 21.046 & 8.591 \\
\hline Sverige & 204.446 & 0 & 1789 & $17 \cdot 367$ & 7.656 \\
\hline
\end{tabular}

8. Varebil 2 benzin, Suzuki Grand Vitara 2.0, GLX, 2007, med fartpilot, tågelygter, aircondition og varme i sæderne, uden automatgear, 5 døre, 140 kW, 11,0 $\mathrm{km} / \mathrm{l}$ (Sverige dog 9,1 km/l)

Tabel 58, del 1-8. Bilmærkers priser og afgifter 1.4.2008

*) E85-biobrændstof sælges ikke i Danmark, biobiler forhandles, men der sælges ingen.

Forhandler oplyser: den kører som tilsvarende benzinbil -30\%, dvs. 13,3$4,0=9,3 \mathrm{~km} / \mathrm{l}$.
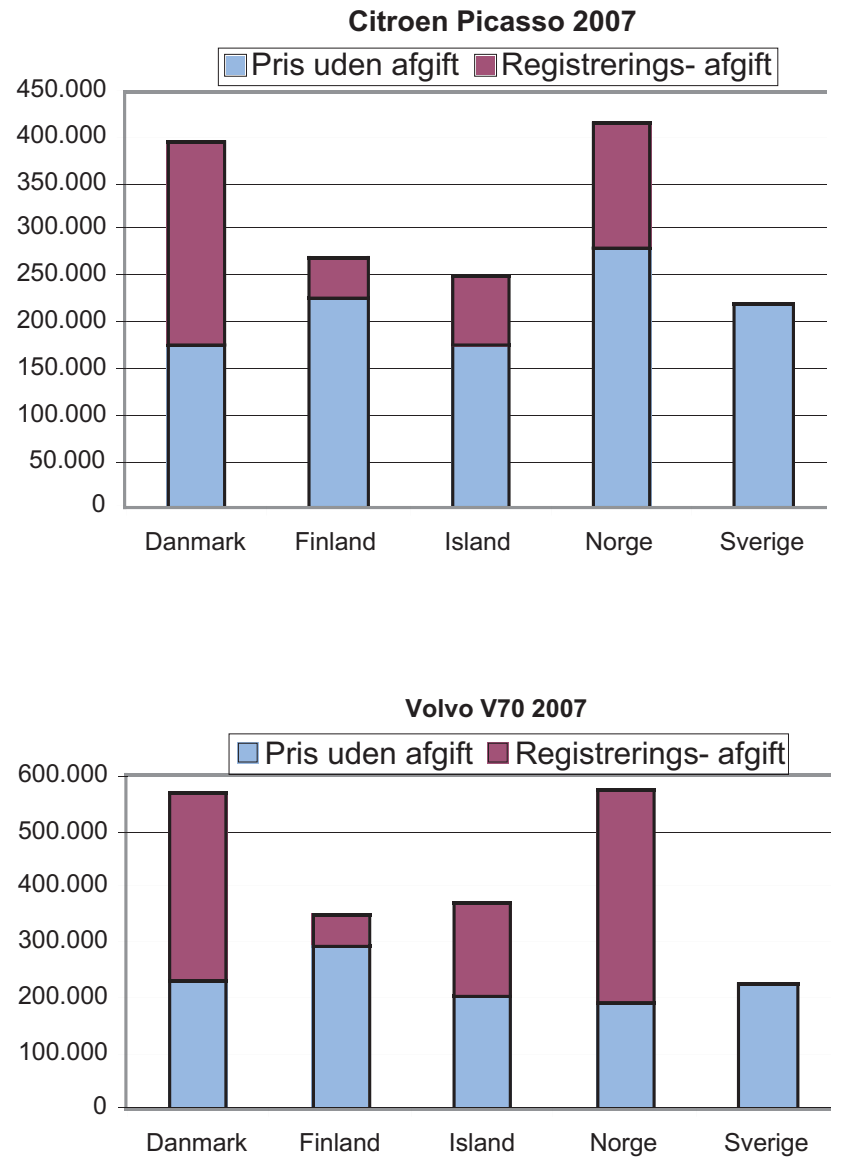


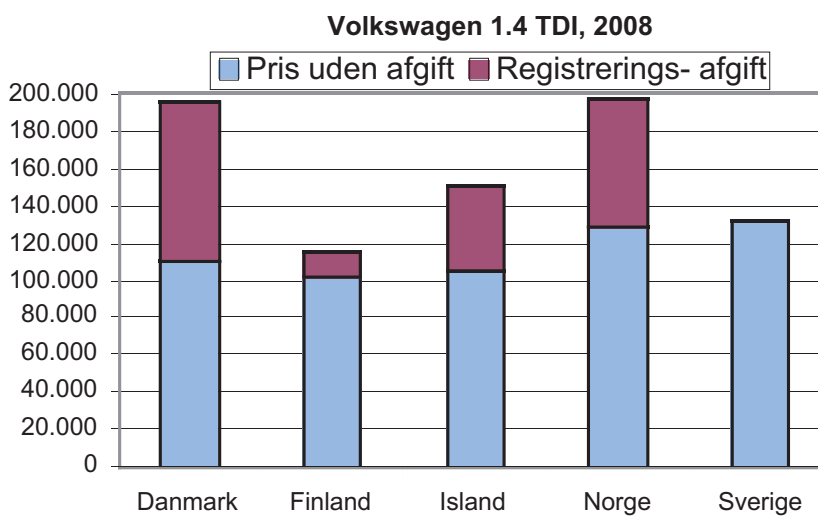

Toyota Aygo 1,0 3-d

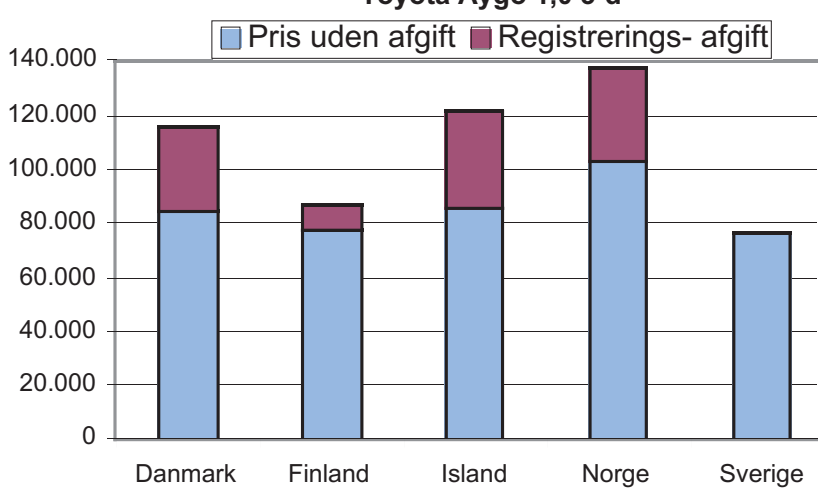

Toyota Prius 1,5 , 2007

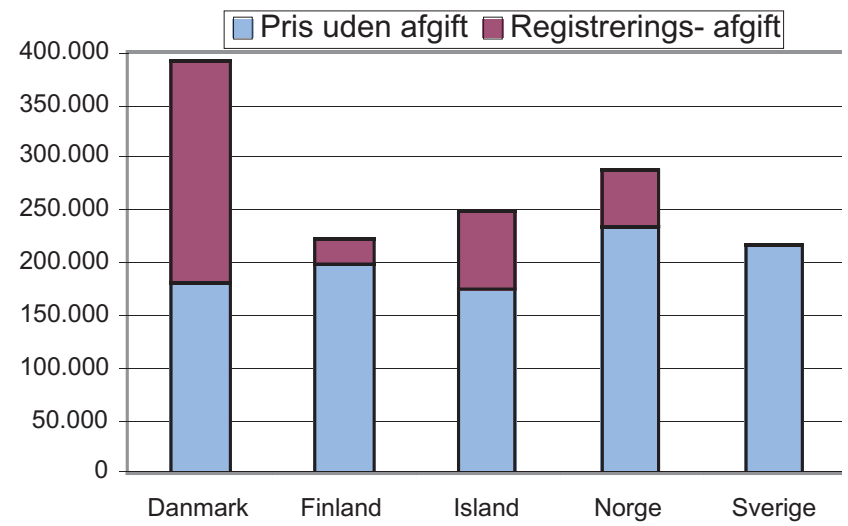

Figur 22, 1-5 De 5 første modeller fra tabel 58 med salgspris, heraf registreringsafgift 
Konklusioner på priseksemplerne:

- Bilprisen. Bilerne koster mest i Norge og Danmark. De mest brændstofforbrugende er generelt dyrere i Norge end i Danmark, omvendt for de mindst brændstofforbrugende. Bilerne er billigst i Sverige og næsten lige så billige i Finland.

- Registreringsafgifterne er også højest i Norge og Danmark. De varierer stærkt. Dieselbiler har højest registreringsafgift i Danmark, mens benzinbiler og varebiler har de største afgifter i Norge. Markant er registreringsafgifter på 0 i Sverige og næsten 0 i Finland.

- Sammenhæng mellem udsalgspris og registreringsafgift. Der er meget lidt sammenhæng mellem registreringsafgifternes størrelse og den fulde udsalgspris på den måde, at nettopriserne eksklusiv skatter ofte er lavere i lande med høje registreringsskatter end i lande uden - f.eks. er nettopriserne ofte højest i Sverige, hvor der ingen registreringsafgift er. Det er måske ikke overraskende, da leverandører og forhandlere i lande med høj registreringsafgift søger at holde priserne nede for at få så højt et bilsalg som muligt. Forskellene viser, at der må være forskel mellem kvaliteter og avancer mellem landene og mellem bilmærkerne. Det er også muligt, at bilsalgets høje og ganske ens andele af erhvervsbiler (som kun er pålagt registreringsafgift i beskedent omfang) medfører, at der er relativt ens og udjævnede priser.

- Ejerafgifterne er højest i Danmark både for person- og varebiler, bortset dog fra små biler og hybridbiler. Sverige har de laveste ejerafgifter bortset fra for dieselbiler.

- Udgifterne til drivmiddel. Der er høje udgifter til drivmidler i Island. Herudover er udgifterne altid højest eller på niveau med de højeste i Norge, men afgiftsdelen heraf er aldrig størst i Norge. Avancerne må således være store i Norge. Dieselafgiften er forholdsvis høj i Island, mens benzinafgiften er det i Finland.

Drivmiddeludgifterne er gennemgående lavest i Danmark (billigst i 4 tilfælde og på niveau med det billigste i de øvrige tilfælde). Samtidig er kørsel pr. køretøj højest i Danmark. Det tyder således på en klar sammenhæng mellem afgiftsniveau og adfærd. Danmark har sammenlignet med de øvrige nordiske lande høj registreringsafgift og lavt bilejerskab, mens Danmark har relativt lave brændstofafgifter og megen kørsel pr. køretøj. 


\section{DEL III: 2. Salg af person- og varebiler efter energifor- brug/vægt}

$\mathrm{CO}_{2}$-udledningen pr. kørt kilometer pr. bil har stor betydning for trafikkens samlede $\mathrm{CO}_{2}$-udledning. Antal biler og kørsel pr. bil er selvfølgelig også væsentlig. Der findes ikke emissionsdata for de samlede bilparker i Norden. Bedre dækket er nybilsalget, som da også leverer en del af dynamikken i bilparkens emissioner.

Både niveauer og udvikling er temmelig forskellige i de nordiske lande. Der er et jævnt fald i $\mathrm{CO}_{2}$-udledning pr. kørt km i nye biler fra år 2000 til år $2006 \mathrm{i}$ Danmark. I Norge er der sket et markant fald i 2007 og 2008. Her er differentieringen af registreringsafgiften efter $\mathrm{CO}_{2}$-udledning kraftigere end den tilsvarende, som blev indført i Danmark i foråret 2007. Også i Finland er der et mærkbart fald i 2008 efter at en ny differentieret registreringsafgift er indført.

Derimod ser der ikke ud til at være sammenhæng mellem de årlige ejerafgifters niveau eller differentiering efter energiforbrug / $\mathrm{CO}_{2}$-udledning og så bilsalgets omfang eller standard i forhold til $\mathrm{CO}_{2}$. Bl.a. blev der i 1997 indført en afhængighed af brændstofforbruget i Danmark. Det har været vanskeligt at spore nogen effekt heraf på bilsalget.

Der er en sammenhæng mellem registreringsafgifternes størrelse i de enkelte lande og de nye bilers emissionsomfang, se tabel 59 og figur 23. Sverige med deres o-registreringsafgift ligger klart øverst med de mest forurenende biler. Endnu mere præcis er sammenhængen dog i forhold til, hvordan registreringsafgifterne er differentierede efter $\mathrm{CO}_{2}$-udledning.

- Norge har differentieret taksterne relativt kraftigt fra 1.1.2007, og emissionstallene er tilsvarende relativt kraftigt forbedrede efter dette tidspunkt

- Finland har differentieret taksterne fra 1.1.2008 og emissionstallene er forbedrede efter dette tidspunkt (der foreligger dog kun de første 3 måneders salgstal for 2008)

- I Danmark ses et gradvist fald i $\mathrm{CO}_{2}$-udslip pr. bil fra omkring år 2000. Danmark har indført differentierede registreringsafgifter fra 1.1.2000, men disse gav kun lettelser til de allermest brændstoføkonomiske som Smartcar og Lupo ${ }^{1}$ og fik derfor kun marginal betydning for den samlede bilpark. Først i foråret 2007 gennemførtes en bred differentiering omfattende alle biltyper. Dette nåede ikke at slå klart igennem i salget i 2007. Omlægningen gav da også en mindre differentiering end den norske.

- I Sverige kobledes årsafgiften (fordonsskatten) til det certificerede $\mathrm{CO}_{2}$ udslip fra omkring 2005, samtidig med at benzinprisen steg og miljødebatten fik betydning. Det må antages, at alle 3 faktorer har medvirket til, at der er sket et vist fald i $\mathrm{CO}_{2}$-udslip pr. solgt benzinbil fra dette tidspunkt. 


\section{Benzin 19951996199719981999200020012002200320042005200620072008}

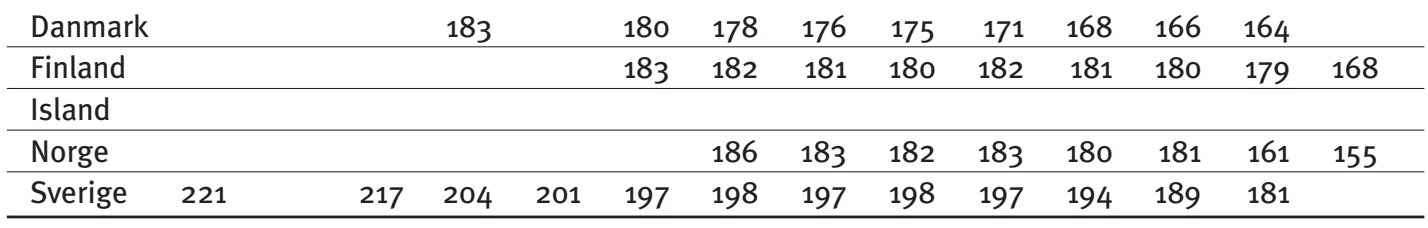

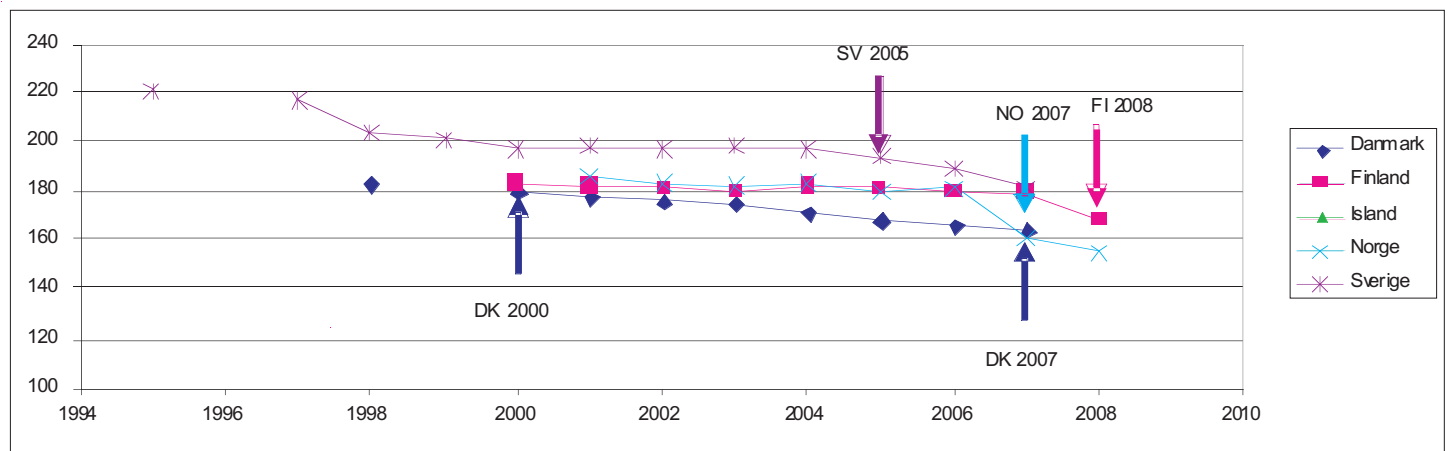

Tabel 59 og figur 23, Nye personbilers gennemsnitlige $\mathrm{CO}_{2}$-udledning, $\mathrm{g}$ pr. kørt kilometer, benzinbiler - med angivelse af de år, hvor de enkelte lande har gennemført afgiftstiltag til fremme af mindre brændstofforbrugende biler. ${ }^{2}$

DK 2000: delvist differentierede registreringsafgifter

DK 2007: øget differentiering

SV 2005: årsafgift koblet til CO2-udslip m.v.

NO 2007: differentiering efter emission

FI 2008: differentiering efter emission

Men der er ikke samme effekt at spore for diesel-personbilerne, især ikke i Danmark. En stor del af dieselbilerne er erhvervsbiler og taxa-vogne. Det er nærliggende at antage, at den manglende effekt skyldes, at afgifter, skatteforhold mv. for erhvervsbiler ikke har de samme miljøhensyn som for privatbiler.

Men ændringen af den danske registreringsafgift for diesel-personbiler i retning af afhængighed af energiforbruget fra sommer 2007 viser sig nu i klart forbedrede emissionstal for disse biler. Desværre foreligger der ikke årstal efter denne ændring, men Danske Automobilimportørers månedlige data viser markant forskydning i retning af salg af små og mere energiøkonomiske dieselkøretøjer.

Der er en tydelig sammenhæng mellem, hvornår registreringsafgifterne gøres afhængig af $\mathrm{CO}_{2}$-emissioner og effekten på bilsalget. I Danmark er afhængigheden indført i 2007 - med en svag forløber i 2000, hvor man gav lettelser til de allermest brændstoføkonomiske - hvor der tidligere har været betalt efter værdi

2 De norske og finske tal for 2008 dækker over bilsalget i årets første 3 måneder. med en svagere kobling til $\mathrm{CO}_{2}$-udslippet. I Norge er kobling til $\mathrm{CO}_{2}$-udslip

først indført fra 1.1.2007 og i Finland er afhængigheden indført fra nytår 2008, 
og en klar effekt er allerede sporet. I de svenske tal synes den såkaldte miljøbonus, som fra april 2007 gives til biler med lavere udslip end $120 \mathrm{~g} / \mathrm{km}$, at begynde at slå igennem (bonussen fungerer som en negativ registreringsskat, dvs. at i stedet for at straffe høje $\mathrm{CO}_{2}$-udslip belønnes lavt udslip).

\section{Diesel $\quad \begin{array}{llllllllllllll}1995 & 1996 & 1997 & 1998 & 1999 & 2000 & 2001 & 2002 & 2003 & 2004 & 2005 & 2006 & 2007 & 2008\end{array}$}

\begin{tabular}{|c|c|c|c|c|c|c|c|c|c|c|c|c|c|}
\hline Danmark & & & 170 & & 149 & 146 & 144 & 143 & 143 & 144 & 148 & 150 & \\
\hline Finland & & & & & 159 & 160 & 165 & 167 & 168 & 172 & 176 & 173 & 158 \\
\hline \multicolumn{14}{|l|}{ Island } \\
\hline Norge & & & & & & 168 & 170 & 174 & 174 & 169 & 173 & 158 & 159 \\
\hline Sverige & 199 & 189 & 174 & 175 & 176 & 178 & 183 & 188 & 189 & 188 & 183 & 176 & \\
\hline
\end{tabular}

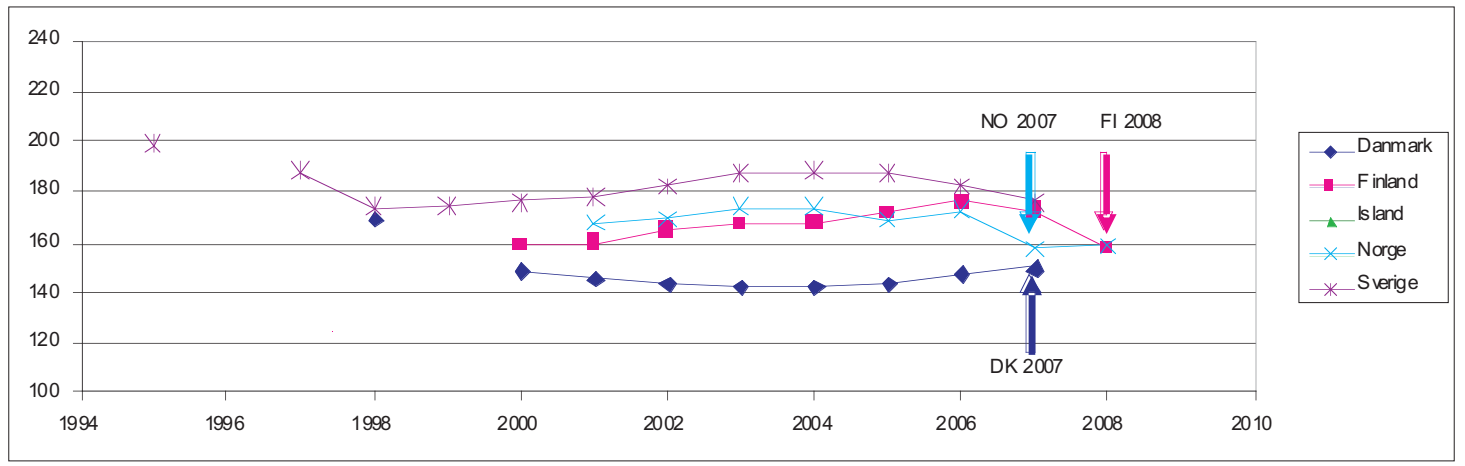

Tabel 60 og figur 24. Nye personbilers gennemsnitlige $\mathrm{CO}_{2}$-udledning, g pr. kørt kilometer, dieselbiler ${ }^{3}$

DK 2007: Sommer 2007 registreringsafgift efter energiforbrug NO 2007: registreringsafgift kobles til $\mathrm{CO}_{2}$-udslip $\mathrm{FI}$ 2008: registreringsafgift kobles til $\mathrm{CO}_{2}$-udslip

Også her er der en væsentlig niveauforskel med de svenske biler klart i top med $\mathrm{CO}_{2}$-udledning. År 2000-06 har der været parallelle stigninger i landene salgstallene fra automobilimportørerne tyder på, at de mange nye 4-hjulstrækker-dieselbiler er blandt årsagerne. I Danmark indtræffer stigningen i gennemsnitlig $\mathrm{CO}_{2}$-udledning pr. kørt km dog først fra 2006. Igen ses et klart fald i Norge i 2007 og 08 efter indførelse af den nye engangsafgift med $\mathrm{CO}_{2}$-afhængig betaling. I Danmark foreligger ikke samlede tal for bilsalg i 2008 indtil nu. Men der er sket en markant ændring i de løbende bilsalgstal i retning af mindre dieselbiler med mindre $\mathrm{CO}_{2}$-udledning efter sommer 2007. Det er sandsynligt, at afgiftsomlægningen er hovedårsag hertil. Det er dog muligt, at også de stigende priser på diesel kan have medvirket til øget salg af energiøkonomiske

3 De norske og finske tal for 2008 dækker over bilsalget $i$ årets første 3 måneder. dieselkøretøjer.

Meget tyder på, at registreringsafgift/engangsafgift er et velegnet instrument 
til påvirkning af bilvalg i mere miljøvenlig retning, i hvert fald hvis afgifterne ligger på et niveau som det danske og norske. Men effekten har ikke været så stærk for dieselkøretøjerne. Det må konkluderes, at incitamenterne til $\mathrm{CO}_{2}{ }^{-}$ begrænsning for dieselkøretøjer har været for svage. I Danmark indførtes $\mathrm{CO}_{2}$ afhængighed af registreringsafgiften først fra 2007. Indtil da virkede andre incitamenter indbygget i bl.a. gulpladebil- og erhvervsbilordninger den modsatte vej, idet de fremmede salg af biler med højt brændstofforbrug. Det må også konstateres, at registreringsafgifterne skal have et vist niveau for at virke. De svenske bilaccisser, der afskaffedes i 1995-2000, var kun på nogle få procent af prisen og havde ikke konstaterbar effekt på bilsalget.

Som gennemsnit for alle $\mathrm{EU}_{15}$-lande har $\mathrm{CO}_{2}$-udslippet fra nye biler (for benzinog dieselbiler) været 186 g/km i 1995 og 162 henholdsvis 161 og 160 i 2004, 2005 og 2006.

Der er ganske store forskelle i nybilsalget mellem personbilernes fordeling på benzin- og dieselmotorer i de nordiske lande, se tabel 61 og figur 25. I statusdelens beskrivelser for de enkelte lande fremgår det, at der sker markante forskydninger, når der ændres i registreringsafgifterne for henholdsvis benzin- og dieselbiler.

\begin{tabular}{l|cccc|cccr} 
Antal biler 0g \% & \multicolumn{4}{|c|}{ Personbiler } & \multicolumn{4}{c}{ Varebiler } \\
& Benzin & $\%$ & Diesel & $\%$ & Benzin & $\%$ & Diesel & $\%$ \\
\hline Danmark, 2006 & 112.966 & 73 & 41.421 & 27 & 5.886 & 9 & 56.868 & 91 \\
\hline Finland *) & & & & & & & & \\
\hline Island, 2007 & 10.758 & 68 & 5.007 & 32 & 9 & 2 & 545 & 98 \\
\hline Norge, 2006 & 56.000 & 51 & 53.000 & 49 & & & & \\
\hline Sverige, 2006 & 195.000 & 78 & 56.000 & 22 & 4.068 & 10 & 35.033 & 90 \\
\hline
\end{tabular}

Tabel 61. Solgte nye biler pr år, fordeling på person- og varebiler samt på benzin- og dieselbiler.

*) De finske tal er ikke opdelt på person-og varebiler.

Figur 25

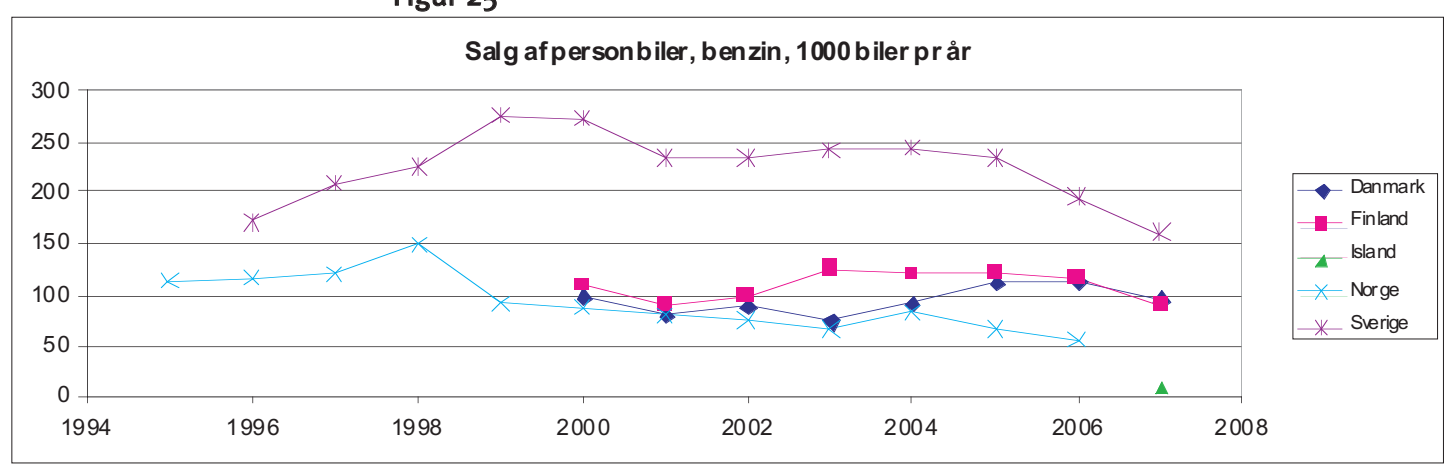

Der gør sig formentlig en betydelig konjunkturfølsomhed gældende for de årli- 
ge salgstal for benzinpersonbiler, mens salgstallene for diesel- og varebilerne synes at udvikle sig mere jævnt. Men tilsyneladende følges konjunkturerne ikke helt ad i landene.

Det er bemærkelsesværdigt, at salget af benzinbiler er halveret i Norge i de viste år.

Figur 26

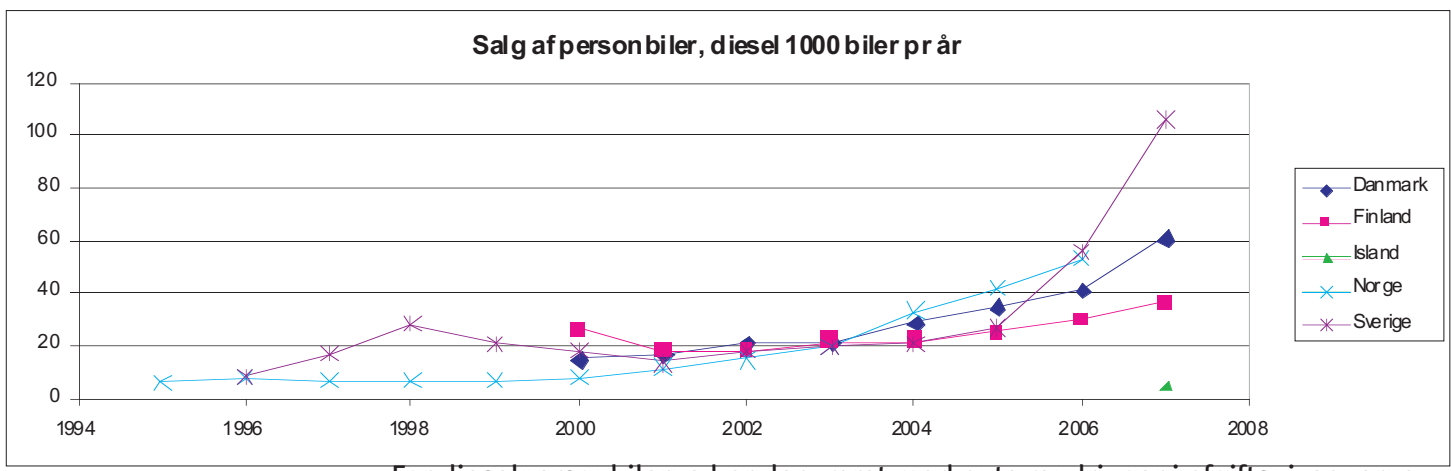

For dieselpersonbilerne har der været markante ændringer i afgiftsniveauerne ved bilkøb. Dette har haft større betydning end konjunkturudsving. Der ses en kraftig stigning i salget af diesel-personbiler i alle landene. Der har været gunstige afgiftsforhold for disse biler, men der har også været modemæssig fokus på bl.a. diesel-4-hjulstrækkere og andre store biler ifølge salgstal fra Danske Automobilimportører, som også viser, at salget af større dieselpersonbiler næsten er helt udfaset igen i 2008 i Danmark. I dag (2008) er næsten 50 \% af de solgte personbiler i Danmark dieselbiler, og formentlig væsentligt over halvdelen af dieselbilerne sælges uden partikelfilter. Fra 2009 forventes partikelfiltre i praksis at blive obligatoriske pga. Euro 5-normerne for nye lette køretøjer ${ }^{4}$.

Figur 27

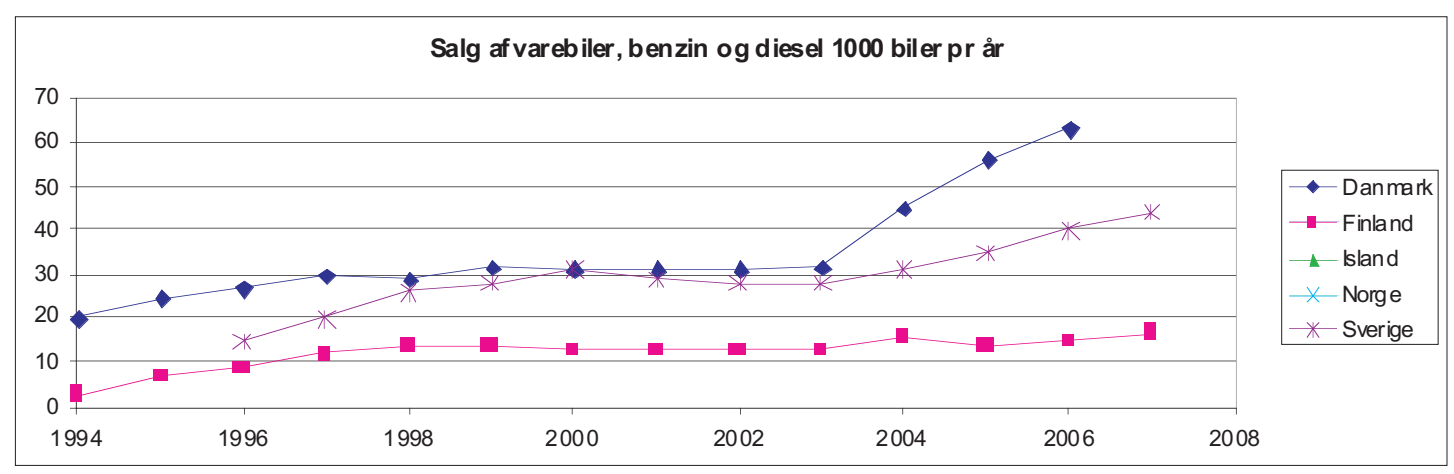

4 Det skal dog bemærkes, at også Euro 5 normerne for lette køretøjer måles som masse $(\mathrm{mg} / \mathrm{km})$. Derfor kan det ikke udelukkes, at fabrikanterne vil kunne leve op til kravet uden partikelfilteruden at mængden af ultrafine partikler (som ikke bidrager væsentligt til partikelmasse) reduceres væsentligt. Dette var netop, hvad der skete med Euro 4 og 5 for tunge køretøjer, hvor man også på forhånd forventede, at kravene ville medføre brug af partikelfiltre 
Salget af varebiler er øget jævnt i de sidste 12 år i landene, se figur 27. Dette hænger sammen med afgifts- og skattelettelse for disse biltyper og blandt andet det forhold, at mange f.eks. i Danmark har set deres fordel i at købe deres 2. personbil som varebil, idet de for denne bil kunne klare sig med 2-3 sæder. Den kraftigere stigning i Danmark fra 2002 til 2006 end i Sverige hænger sammen med, at den økonomiske fordel for private ved at indregistrere deres bil som varebil (gule plader) frem til foråret 2007 var langt større i Danmark. Erhvervslivets forskellige udviklinger i landene kan dog have betydning for forskellene også. Man kan også, jf. tabel 67 konstatere, at de lande (Danmark og Norge), som har de laveste antal biler pr 1000 indbyggere har de højeste antal varebiler pr 1000 indbyggere. 


\section{DEL III: 3. Bestand af person- og varebiler i alt og pr indbyggere}

\begin{tabular}{|c|c|c|c|c|c|c|}
\hline \multirow[t]{2}{*}{ Bilbestand } & \multicolumn{2}{|c|}{ Personbiler } & \multicolumn{2}{|c|}{ Varebiler } & \multirow{2}{*}{$\begin{array}{l}\text { Pers-+varebiler } \\
\text { Pr } 1000 \text { indb }\end{array}$} & \multirow[t]{2}{*}{ Arstal } \\
\hline & & & I dill & & & \\
\hline Danmark & 2.013 .899 & 370 & 458.968 & 84 & 454 & Ult 2006 \\
\hline Finland & 2.570 .356 & 492 & 97.187 & 19 & 511 & $2004 / 2007$ \\
\hline Island & $\left.158.986^{*}\right)$ & 508 & 7.466 & 24 & 532 & 2007 \\
\hline Norge & 2.084 .193 & 445 & 330.761 & 71 & 516 & 2006 \\
\hline Sverige & 4.202 .463 & 485 & 401.110 & 46 & 531 & 2006 \\
\hline
\end{tabular}

Tabel 62, Person- og varebiler og befolkning.

*) Reykjavik 2004:591

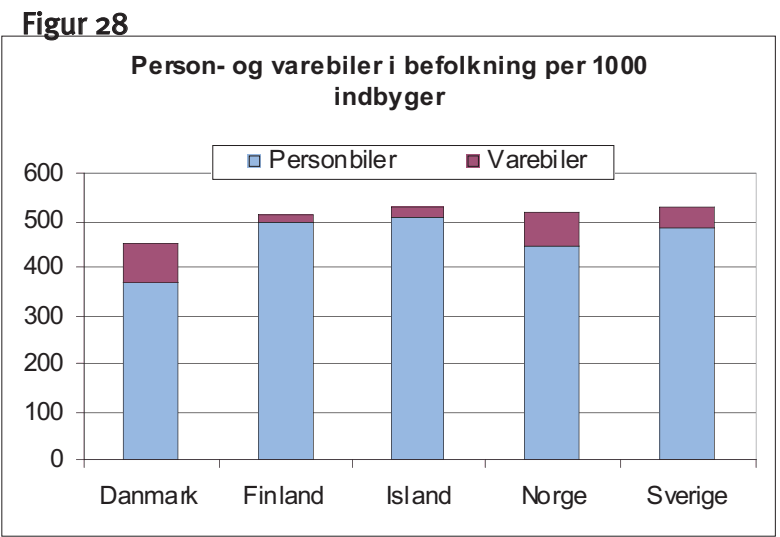

Danmark og Norge har markant højere registreringsafgifter end de øvrige lande, og antal personbiler er relativt lavere. I disse 2 lande er antal varebiler pr. 1000 indbyggere til gengæld markant højere end i de øvrige lande. Det skyldes sandsynligvis, at incitamentet til at søge at undgå registreringsafgifter ved at vælge at købe varebiler er større her. Man ser samtidig, at der blandt disse varebiler er mange af en "skatteteknisk kategori", idet de er egentlige personbiler

Der er færrest biler pr. 1000 indbyggere i Danmark, som også har nogle af de højeste registreringsafgifter i Norden. I Norge er de dog lige så høje, og her har man også relativt få biler pr 1000 indbyggere - dog ikke så få som i Danmark. Selv hvis man lægger person- og varebiler sammen er der 17 \% flere biler i Sverige end i Danmark pr 1000 indbyggere, se figur 28.

\begin{tabular}{l|lcccc|ccccc} 
& \multicolumn{7}{|c|}{ Personbiler } & \multicolumn{7}{c}{ Varebiler } \\
& Benzin & $\%$ & Diesel & $\%$ & I alt & Benzin & $\%$ & Diesel & $\%$ & I alt \\
\hline Danmark, 2006 & 1.758 .286 & 87 & 255.444 & 13 & 100 & 95.563 & 21 & 363.345 & 79 & 100 \\
\hline Finland & \multicolumn{1}{|c}{} & & & & & & & & & \\
\hline Island, 2007 & & & 16 & 100 & & & & \\
\hline Norge, 2006 ult & 1.688 .460 & 81 & 386.772 & 19 & 100 & 74.909 & 23 & 254.869 & 77 & 100 \\
\hline Sverige, 2007/08 & 3.804 .983 & 92 & 351.896 & 8 & 100 & 120.469 & 28 & 303.451 & 72 & 100 \\
\hline
\end{tabular}

Tabel 63. Bilparken fordelt på person- og varebiler samt på benzin- og dieselbiler 
Dieselandelene varierer mest for personbiler, hvor der er over dobbelt så stor andel i Norge som i Sverige, se tabel 63. Det ser ud til at have skattemæssige årsager. Men der er solgt ekstraordinært mange dieselpersonbiler de sidste 2 år i Sverige. Historisk har de høje årlige ejerskatter på dieselbiler i Sverige gjort det fordelagtigt at vælge benzin. Dette er ændret betydeligt gennem en skatterabat på $6.000 \mathrm{sv}$ kr. for diesel med partikelfilter, $\mathrm{CO}_{2}$-baseret ejerafgift, sænket dieselmultiplikator samt miljøbilsbonus. Dette er en forklaring på det dramatisk øgede salg af dieselbiler de sidste 2 år i Sverige.

\begin{tabular}{|c|c|c|c|c|c|}
\hline \multicolumn{4}{|c|}{$\begin{array}{lll}\text { Personbiler } & \end{array}$} & \multicolumn{2}{|c|}{ Varebiler } \\
\hline (n) & $\begin{array}{r}\text { Genner } \\
2000 / 01\end{array}$ & $\begin{array}{l}\text { alder } \\
2006\end{array}$ & Andel over 10 år & $\begin{array}{c}\text { Gennemsnitlig } \\
\text { alder }\end{array}$ & Andel over 10 år \\
\hline Danmark & 7,8 & 9,1 år & $38 \%$ & & $24 \%$ \\
\hline Finland & 10,4 & 10,5 år & & & \\
\hline Island & & 9,2 år & & 9,9 år & \\
\hline Norge & 9,9 & 10,2 år & $50 \%$ & 7,0 år & \\
\hline Sverige & 9,6 & 9,1 år & $43 \%$ & Tal findes ikke & Tal findes ikke \\
\hline
\end{tabular}

Tabel 64. Person- og varebilers gennemsnitlige alder, *) "Andre biler"

Danmark og Sverige har en bilpark med samme alder, selv om Danmark har en markant registreringsafgift, mens Sverige ingen har. Og i Finland, som har en meget lav registreringsafgift, er gennemsnitsalderen højest. Det påvirker altså næppe bilparkens alder, at der er en registreringsafgift af en vis størrelse. Det kan også noteres, at der hurtigt kan ske forskydninger i bilparkens alder i landene. Hvor der i 2000/01 var en bilpark i Sverige, som var $23 \%$ ældre end den danske, er der ingen forskel i $2006^{5}$

Bilparken i Finland har en relativt høj alder - og et stort brændstofforbrug.

\begin{tabular}{lrrrrrrr} 
Personbiler & Elbiler & $\begin{array}{r}\text { E85, bio- } \\
\text { brændstof }\end{array}$ & Hybrid & Gas Hydrogen & $\begin{array}{r}\text { I alt, \% i forhold til } \\
\text { personbilpark, } \\
\text { jf tabel 67 }\end{array}$ & $\begin{array}{r}\text { Ar for } \\
\text { statistik }\end{array}$ \\
\hline Danmark & 151 & 0 & 0 & 12 & 0 & 0,008 & 2006 \\
\hline Finland & 0 & 0 & 0 & 200 & 0 & 0,008 & 2007 \\
\hline Island & & 2 & 300 & 100 & 10 & 0,191 & 2007 \\
\hline Norge & 1.500 & 2.250 & 55 & 176 & 0 & 0,191 & 2006 \\
\hline Sverige & 126 & 80.934 & 9.598 & 10.896 & 0 & 2,417 & 2007 \\
\hline
\end{tabular}

Tabel 65. Personbilpark, antal biler på alternativt brændstof. Ethanol = biobrændstof

5 I øvrigt havde den danske bilpark tidligt i 2007 en gennemsnitlig alder på 8,5 år og tidligt i 2008 på 9,3 år.
Kun Sverige har en andel af bilparken på alternative brændstoftyper, som har nogen mærkbar betydning i det samlede billede. E85-biler, men også hybrid- og gasbiler er ret udbredt i Sverige. I Norge og (som andel af bilparken) Island er der satset lidt på alternative brændstof-biler. Norge har et vist volumen af E85biler og elbiler. Danmark og Finland har ikke alternativt brændstof af betydning i bilparken. 


\begin{tabular}{|c|c|c|c|c|c|c|c|c|}
\hline Varebiler & Elbiler & $\begin{array}{r}\text { Bio- } \\
\text { brændstof }\end{array}$ & Hybrid & Gas & Hydrogen & $\begin{array}{r}\text { Andet } \\
\text { end el } \\
\text { (Norge) }\end{array}$ & I alt & $\begin{array}{r}\text { Ar for } \\
\text { statistik }\end{array}$ \\
\hline Danmark & 35 & 0 & 0 & 18 & 0 & & 53 & 2006 \\
\hline \multicolumn{9}{|l|}{ Finland } \\
\hline \multicolumn{9}{|l|}{ Island } \\
\hline Norge & 69 & & & & & 18 & 87 & 2006 \\
\hline Sverige & & & & & & & 2.542 & \\
\hline
\end{tabular}

Tabel 66. Varebilpark (lette lastbiler), antal biler på alternativt brændstof. Ethanol = biobrændstof 


\section{DEL III: 4. Kørselsomfang}

Generelt er data for kørselsomfang mindre sikre end f eks tal for bil- og brændstofsalg. Der er to hovedkilder: punkttællinger som opregnes til trafikarbejde og transportvaneundersøgelser, som tager udgangspunkt i den enkelte trafikants daglige transport.

\begin{tabular}{|c|c|c|c|c|c|c|c|c|c|c|c|c|c|c|c|c|c|}
\hline & 90 & 91 & 92 & 93 & 94 & 95 & 96 & 97 & 98 & 99 & oo & 01 & 02 & 03 & 04 & 05 & 06 \\
\hline Danmark & 27,0 & & & & & & & & & & & & & & & & 34,0 \\
\hline Finland & & & & & & & & & & & & & & & & & \\
\hline Island & & & & & & & & & & & & & & & & & \\
\hline Norge *) & 23,0 & 229 & 229 & 232 & 23,6 & 23,7 & 24,7 & 24,6 & 25,2 & 25,4 & 25,8 & 26,4 & 27,4 & 28,2 & 28,8 & 29,6 & 29,9 \\
\hline Sverige & 55,8 & 56,2 & 56,9 & 55,6 & 56,3 & 56,9 & 57,1 & 57,2 & 57,7 & 58,9 & 59,7 & 60,2 & 62,0 & 62,5 & 63,0 & 63,2 & 63,0 \\
\hline
\end{tabular}

Tabel 67. Trafikarbejde, personbiler pr. år, milliarder vognkilometer, DK kilde: Langsigtet fremskrivning af vejtrafik, DTF 2007, N kilde: Arne Rideng, Transportøkonomisk institutt,2007: Transportytelser i Norge 1946-2006

*) Gælder personbiler til persontransport ekskl. lejebiler. Varebiler til sådanne formål er inkluderet.

\begin{tabular}{l|c|c|c|c|c|c|c|c|c|c|c|c|c|c|c|c|c|c}
\hline & 90 & 91 & 92 & 93 & 94 & 95 & 96 & 97 & 98 & 99 & 00 & 01 & 02 & 03 & 04 & 05 & 06 \\
Danmark & 6,0 & & & & & & & & & & & & & & & & 9,0 \\
\hline Finland & & & & & & & & & & & & & & & & & & \\
\hline Island & & & & & & & & & & & & & & & & & & \\
\hline Norge **) & & & & & & & & & & & & & & 2,8 & & & & \\
\hline Sverige & 3,8 & 3,9 & 4,0 & 3,9 & 3,9 & 4,0 & 4,0 & 4,1 & 4,3 & 4,5 & 4,7 & 5,0 & 5,4 & 5,7 & 5,9 & 6,3 & 6,7 \\
\hline
\end{tabular}

Tabel 68. Trafikarbejde med varebiler pr. år, milliarder vognkilometer. Danmark kilde. DTF 2007 **) Spørgeundersøgelse fra 2003 (tal i mia. køretøjskm): små varebiler (1,6), kombinerte biler $(0,2)$, store varebiler (0,5), små lastbiler (under 3,5 ton) (0,5). Kilde: Transportøkonomisk institutt, rapport 720/2004.

Danskerne råder over lidt færre biler end andre vesteuropæiske befolkninger. Til gengæld køres længere pr bil. 1980-2005 er biltrafikken vokset med 73 \%, og antal motorkøretøjer øget med 32 \% i Danmark. Der er flere årsager til stigningerne: voksende befolkning, flere arbejdspladser, øget spredning i bosætning, øget velstand mv. Effekten af ændringer i afgiftstyper og -niveauer kan næppe umiddelbart udskilles selvstændigt. I Danmark køres i alt 9.800 km pr indbygger i person-, vare- og taxabil.

Figur 29. Kilde (2)

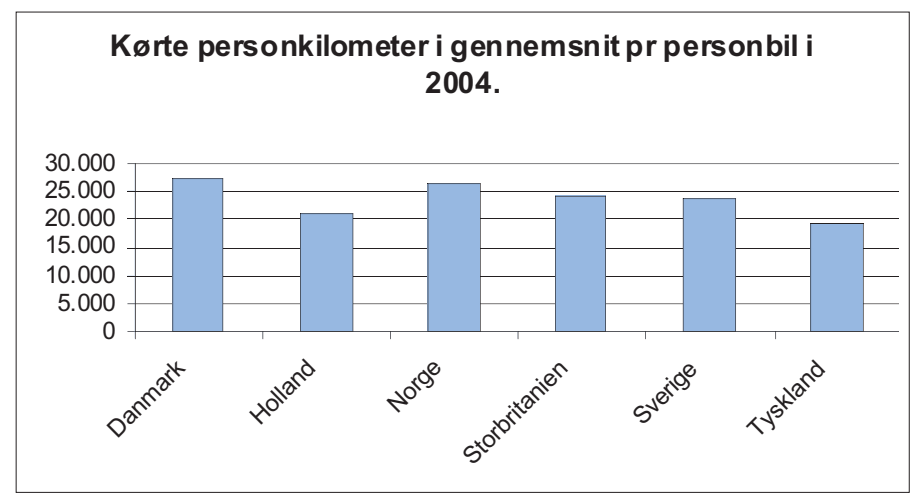


Der køres $16 \%$ mere pr. personbil i Danmark end i Sverige. Men som følge af det højere bilejerskab i Sverige (se tabel 67), køres der 13\% flere personkilomenter i bil, målt pr. indbygger i Sverige end i Danmark - og Norge ligger helt på linie med Sverige. De meget større afstande i Sverige kunne give forventning om, at forskellen var større. Den relativt store kørsel i Danmark kan hænge sammen med, at den kollektive trafik står for en større andel af transporten i Sverige end i Danmark. Desuden har Danmark mange vejkilometer og en spredt bosætning i høj grad i parcelhuse. Det kan medføre forholdsvis lange ture. De medtagne tal for lande i det øvrige Europa peger heller ikke på, at kørselsomfanget har så meget med landestørrelser eller befolkningstæthed at gøre. Der køres dog kortere ture i storbyer end i landområder.

\begin{tabular}{|c|c|c|c|c|c|}
\hline & Gennemsn & itlig rejselængde pr døgn & & & raf i bil \\
\hline & Hele landet & Større byer / hovedstaden & Ar & Hele landet & Større byer/hovedst \\
\hline Danmark & $44,8 \mathrm{~km}$ & 37,4 km (større byer) & 2006 & $36,9 \mathrm{~km}$ & $21,6 \mathrm{~km}$ \\
\hline Finland & & & & & \\
\hline Island & & 13,7 km (Reykjavik) & 2002 & & \\
\hline Norge & $37,4 \mathrm{~km}$ & & 2001 & & \\
\hline Sverige & $40,0 \mathrm{~km}$ & & 2006 & & \\
\hline
\end{tabular}

Tabel 69. Gennemsnitlig rejselængde pr døgn pr voksen person i landene opgjort efter bosætning. Kilde: Rejsevaneundersøgelser 


\section{DEL III: 5. Brændstoftyper, forbrug i alt}

Forbruget af brændstof afhænger såvel af antal biler, som kørte kilometer pr. bil, men også af motorteknik samt valg af brændstoftype. Et ønske om at reducere biltrafikkens $\mathrm{CO}_{2}$-bidrag må favne alle de nævnte udviklinger. Samlet er der ikke sket nogen markant ændring i trafikkens samlede energiforbrug, idet indtrufne fald f.eks. i benzinforbrug typisk ledsages af øget dieselbrug.

Bilparken øges år for år, jf. del II. Kørslen pr. indbygger eller pr. bil øges også, jf. tabel 67. $\mathrm{CO}_{2}$-udslippet pr. kørt kilometer i nye biler har jf. figur 23 og 24 haft forskellige forløb, men især fra 2006 og 2007 er der sket en lille reduktion i en del lande. Jf. figur 23 er der fra 2001 til 2007 sket en reduktion på i gennemsnit $7 \%$ i CO 2 -udslip pr. ny bil i Danmark, Finland, Norge og Sverige tilsammen. Der er sket en lille nedgang i benzinsalget i de samme år, men samtidig er dieselsalget dog øget en hel del.

\begin{tabular}{|c|c|c|c|c|c|c|c|c|c|c|c|c|c|}
\hline Benzin & 1975 & 1985 & 1995 & 1997 & 1999 & 2000 & 2001 & 2002 & 2003 & 2004 & 2005 & 2006 & 2007 \\
\hline Danmark & & & 2.380 & 2.590 & 2.710 & 2.710 & 2.640 & & 2.610 & 2.580 & & 2.016 & 2.440 \\
\hline Finland & & & & & & & & & & & & 2.576 & 2.481 \\
\hline Island & 77 & 98 & 137 & 138 & 143 & & 142 & & 143 & & & 225 & \\
\hline Norge & & & 2.159 & 2.204 & 2.196 & & 2.195 & & 2.157 & & 2.082 & 1.997 & 1.896 \\
\hline Sverige & 4.376 & 5.068 & 5.763 & 5.429 & 5.453 & 5.373 & 5.418 & 5.525 & 5.547 & 5.557 & 5.508 & 5.363 & 5.268 \\
\hline \multicolumn{14}{|l|}{ Diesel } \\
\hline Danmark & & & 1.640 & 1.690 & 1.770 & 1.790 & 1.850 & & 1.980 & 2.110 & & & \\
\hline Finland & & & & & & & & & & & & 2.549 & 2.607 \\
\hline Island & 25 & 32 & 38 & 39 & 40 & & 47 & & 49 & & & 60 & \\
\hline Norge & & & 985 & 1.092 & 1.192 & & 1.302 & & 1.415 & & 1.626 & 1.766 & 2.019 \\
\hline Sverige & 2.308 & 2.446 & 3.119 & 3.232 & 3.502 & 3.513 & 3.556 & 3.717 & 3.854 & 4.073 & 4.271 & 4.422 & 4.683 \\
\hline
\end{tabular}

Tabel 70. Salg af drivmidler, $1000 \mathrm{~m}^{3}$. Diesel såvel til person- og varebiler som til busser, lastbiler mv. DK, 2006-7 er tal fra DS databank, forbrug af motorbenzin

I Danmark har der for benzin været en stigning i forbruget frem til en top i årene 1999-2004 og et vist fald i de sidste par år. I Sverige nåedes max-forbrug i 1989, derefter har forbruget varieret, men stort set ligget stille. En nedgang begyndte i 2006. I Norge har forbruget ligget temmelig konstant hele tiden, men et fald ser ud til at være sat ind fra 2005.

For diesel har der derimod været en jævn stigning i forbruget i alle lande gennem årene.

\begin{tabular}{lrrr} 
Ethanol-salg & $5 \%$ i alm benzin & E85 & Ar \\
Danmark & $?$ & 0 & \\
Finland & $?$ & & \\
\hline Island & $?$ & & \\
\hline Norge & $?$ & & \\
\hline Sverige & 114.000 & 244.000 & 2007 \\
\hline
\end{tabular}

Tabel 71. Salg af ethanol, $\mathrm{m}^{3} \mathrm{pr}$ år. 
Det er typisk dyrest i brændstof at køre bil i Norge og billigst i Danmark, jf. afsnit III.1 med cases for bilmærker. Dette kan i nogen grad ses afspejlet i kørselsomfanget. Som nævnt ovenfor, køres i Danmark længst pr. bil, og målt som kørelængde pr. indbygger, ligger Danmark kun 13\% under Norge og Sverige, på trods af de langt mindre afstande i Danmark. 


\section{DEL IV: Potentialer for $\mathrm{CO}_{2}$-besparelser}

\section{DEL IV: 1. Analyser af potentiale ved skift til mere energieffektive biler}

Vigtige elementer i indsatsen for at skabe en bilpark med bedre miljømæssig standard er dels teknologiske forbedringer af motorerne, dels udskiftning af bilparken til nye biler, såfremt disse har bedre standarder.

Bilerne i de nordiske lande er i gennemsnit 9-10 år gamle, svarende til en gennemsnitlig alder ved ophugning på 18-20 år - eller lidt mere fordi der er en voksende bestand. Det tager altså mange år at få bilparkens mange biler med stort brændstofforbrug udskiftet. Der kan være behov for både at drive en teknologisk udvikling af bilmotorerne frem, og for at fremme udskiftning til de bedre biler.

Denne problemstilling er behandlet $i$ et samarbejdsprojekt mellem de nordiske transportministre i 2003: Rapid Replacement of Passenger Cars - a Pathway to Sustainable Mobility?

Med Sverige som case ses på situationen i 2015, dels i et basisscenarie, dels i et hurtigt udskiftningsscenarie med 3 varianter:

1. Udskiftning af alle biler, der er ældre end 10 år til samme motortype (benzin - diesel),

2. Udskiftning af alle biler kun til biler med benzinmotorer, som er ligesom den bedste benzinbil i dag

3. Udskiftning kun til biler med dieselmotorer, som alle er ligesom den bedste dieselmotor i dag.

Der ses også på effekten, hvis scenarierne realiseres for alle de nordiske lande. Der vil være variationer mellem landene, fordi der er forskelle på bilparkens alder og sammensætning. Der vil ske forbedringer for emissionsniveauerne især for $\mathrm{HC}, \mathrm{CO}$ og $\mathrm{NO}_{\mathrm{x}}$ også i basisscenariet, en mindre forbedring for partikeludslip og en vis stigning i $\mathrm{CO}_{2}$-udledning (+3 \%), idet længere kørsel pr. bil overstiger betydningen af forbedringerne af bilparken.

I hurtigt-udskiftnings-scenarie I vil de nævnte forbedringer være større, og for $\mathrm{CO}_{2}$ vil der ske en reduktion på $6 \%$ for hele bilparken, i scenarie II spares $22 \%$ $\mathrm{CO}_{2}$, og i scenarie III $46 \%$.

Der er således betydningsfulde potentialer for $\mathrm{CO}_{2}$-besparelser for bilparken, hvis der er instrumenter til at fremme udskiftning af bilerne, og det vel at mærke sker til energiøkonomiske biler.

Men i en livscyklusberegning vil øget $\mathrm{CO}_{2}$-udledning til bilfremstilling opveje besparelserne ved $k ø$ rslen med bilerne. Dog vil scenarie III give en samlet gevinst på $20 \% \mathrm{CO}_{2}$, se boxen. Alt i alt kan konkluderes: at der er store perspektiver i at fremme valg af energieffektive biler ved udskiftning, men at en $\emptyset$ get udskiftningshastighed samlet set ikke er en fordel - eller i bedste fald en begrænset fordel. 
Det fører så tilbage til fokus på de afgiftstyper, som kan påvirke trafikanternes valg, når de køber ny bil.

Rapporten ser også på økonomiske, sociale og innovationsmæssige forhold. Hurtig udskiftning får betydning for lavindkomstgrupper, som skal have råd til de nye biler. Samtidig får disse grupper mindre for deres eventuelle brugte biler, hvis de sælges, idet den hurtige udskiftning vil medføre lave brugtbilpriser. Sverige skiller sig ud som et betydningsfuldt bilproducerende land, som vil få væsentlige effekter i form af beskæftigelse mv.

Rapport til de nordiske transportministre, 2003:

Rapid Replacement of Passenger Cars:

Hvis alle biler udskiftes til benzinbiler af en miljømæssig kvalitet som den bedste benzinbil i dag vil der spares $\mathrm{CO}_{2}$ til bilernes kørsel, men det opvejes af øget $\mathrm{CO}_{2}$ til bilproduktion.

Udskiftes tilsvarende til dieselbiler er der i en livscyklus-betragtning en besparelse på $20 \% \mathrm{CO}_{2}$ alt i alt.

Konklusion: Der er ingen grund til at fremme hurtig udskiftning til nye benzinbiler. Der kan være det til dieselbiler.

Perspektiverne i at påvirke bilvalget, når der købes bil alligevel, er større. 


\section{DEL IV: 2. Diskussion af krav til miljøvenlige biler}

Målene om $\mathrm{CO}_{2}$-reduktion kan nås. Analyser viser, at det er nødvendigt at gøre en indsats både med hensyn til motorteknik og afgifter, for at de opstillede mål kan nås. Til gengæld er der ikke noget, der peger i retning af, at målene ikke kan nås, hvis begge typer indsats anvendes målrettet.

Alle miljøproblemer må med i indsats. Jævnfør tidligere er de uheldige miljømæssige konsekvenser af bilkørsel af et omfang, så der må tages alvorligt fat i dem. Samtidig er det også velkendt, at konsekvenserne er mangeartede. Det er vigtigt, at der ikke fokuseres ensidigt på enkelte af disse, men at effekterne vurderes samlet.

Tidligere er der med held sket reduktioner af bly, kulilte, kulbrinter mv. fra bilerne. Derimod er der først sent taget initiativer til at begrænse bilernes klimapåvirkning især med drivhusgassen $\mathrm{CO}_{2}$. Der bør ikke ske en optimering alene med henblik på $\mathrm{CO}_{2}$-emissioner. Det kunne f.eks. ske ved stort set fuldstændigt at overgå til diesel-teknik. Det vil imidlertid umiddelbart medføre, at partikler og $\mathrm{NO}_{\mathrm{x}}$-emissioner øges mærkbart. Til gengæld kan der ved overgang til diesel kombineret med påbud om filter og katalysator på bilerne opnås såvel en reduktion af $\mathrm{CO}_{2}$ som $\mathrm{NO}_{\mathrm{x}}$ - uden at udslip af partikler øges væsentligt, forudsat at filtrene behandles og kontrolleres korrekt, herunder at eventuel nødvendig afrensning af nanopartikler foretages.

Afgiftsniveauerne for benzin og diesel bør afspejle de samlede eksternaliteter ved brug af de to slags drivmiddel. Det er selvfølgelig vanskeligt, fordi især klimapåvirkningen er svær at opgøre præcist, og fordi der typisk anvendes økonomiske metoder, som vægter kortsigtede effekter, men nedtoner de langsigtede konsekvenser - som drivhuseffekten ${ }^{6}$. Men princippet om, at også bilister skal betale for deres miljøpåvirkninger er sundt og blandt andet også anerkendt af EU. Biler kører væsentligt længere på literen på diesel end på benzin, og de påvirker derfor også omgivelserne mere pr. liter diesel end pr. liter benzin i form af vejslid, støj, ulykker osv. Klimapåvirkningerne er alvorlige og bør veje tungt. Men der bør også - i mindre omfang - tages hensyn til de øvrige eksternaliteter ved afgiftsniveauernes fastlæggelse. Selv om dette sker, vil der stadig være en væsentlig fordel ved dieselkørsel (forudsat katalysator og filter), som kan komme klimapåvirkningen til gode, idet klimadelen af afgiften bør være den største.

Ofte anvendes cost-benefit beregninger med en relativt høj diskontering, på 5-6\%. Det betyder, at konsekvense som opstår efter 100 års forløb eller mere, ved tilbagediskontering til nutidsværdi, tæller meget lidt i regnestykkerne
Varebiler og firmabiler bør beskattes på linje med andre biler. De miljømæssige konsekvenser er for uheldige ved at se igennem fingre med miljøhensyn både i fastlæggelse af afgiftstyper i det hele taget, af afgiftsniveauer og af fradrag. Beskatningen skal sikre, at der er incitament til at vælge biler i den nødvendige størrelse, også til erhvervskørsel, hvor den nuværende lempelige beskatning motiverer til store bilstørrelser. Mulighederne for at få bil delvist uden afgift til privat brug bør afskaffes. 


\title{
DEL V: Styringsmidler til fremme af køb og brug af biler med mindre energiforbrug
}

\author{
DEL V: 1. Beskatning efter energiforbrug (registrerings \\ afgift og ejerafgift)
}

I Danmark har man i 2007-08 undersøgt særligt energiøkonomiske biler, og biler der er ombygget til varebiler -her er tale om "afgiftstekniske varebiler" (gule plader), som ikke nødvendigvis kører med varer. Det konstateres, at reducerede bilafgifter for visse biltyper i høj grad har påvirket bilkøbernes valg af biltype og -model. Til gengæld har lempelserne ikke i sig selv haft væsentlig betydning for beslutningen om bilkøb. Men det konstateres, at de høje danske registreringsafgifter har generel betydning for det lave danske bilejerskab. ${ }^{7}$

Det påvises, at de købte energiøkonomiske biler får trafikanterne til at køre 10$15 \%$ længere, end de ellers ville have gjort. Netto spares der dog energi, idet disse biler kører dobbelt så langt på literen som almindelige biler.

Varebilskøberne kører også længere end før de fik varebil. Prisen på drivmiddel påvirker således trafikanternes transportomfang.

Afgiftsdifferentiering har en vis effekt, hvis differentieringen hænger sammen med konkrete valg i købsøjeblikket, som det sker både ved bilkøb og drivmiddelkøb.

Analyserne i dette projekt for Nordisk Ministerråd viser på samme måde, at de afgifter, som falder i direkte sammenhæng med køb, som kan påvirkes, har de bedste muligheder for at få forbrugerne til at træffe miljømæssigt hensigtsmæssige valg. Hermed menes, at registreringsafgifter og brændstofafgifter falder på tidspunkter, hvor man kan vælge mellem bilmærker eller niveau eller type af brændstof. Tilsvarende virker kørselsafgifter og parkeringsafgifter, jf. senere, som er direkte knyttet til valget om henholdsvis at køre og parkere.

Erfaringerne viser også, at det ikke påvirker forbrugsvalget ret meget, hvis der gives et tilskud til et mere miljørigtigt valg, men ikke så meget, at købet er billigere end alternativet. Det miljørigtige valg må være det billigste.

\section{Analyser i denne rapport tyder på:}

- at registreringsafgifter er et udmærket middel til at påvirke trafikanterne til at træffe miljømæssigt gode valg, jf. figur 23 og 24. De senere års differentiering efter energiforbrug og $\mathrm{CO}_{2}$-emission har haft markante og gunstige effekter på bilsalget. Registreringsafgifterne ser ud til at være mest virkningsfulde af de undersøgte afgiftsformer.

- at drivmiddelafgifter på samme måde i høj grad kan påvirke trafikanterne til miljømæssigt gode valg, hvis brændstof med bedre miljøkvalitet skal indføres på markedet, jf. tabel 55. Men også bosætning, rejsemønster og transportmiddelvalg påvirkes formentlig af udgiften til drivmidler, jf. tabel 55 (benzin og diesel er gennemgående dyrest i Norge og billigst i Danmark) og figur 29 (der køres mest pr. bil i Danmark)

- at ejerafgifterne ikke påvirker trafikanterne synderligt i deres forbrugsvalg. 
Ved bilkøb må bilpris og registreringsafgift antages at være så dominerende i forbrugerens bevidsthed, at differentierede ejerafgifter ikke spiller den store rolle. Og i det daglige kørselsforbrug spiller ejerafgifterne ikke nogen rolle. Dette er et gennemgående indtryk også fra dialog med forskere og fagfolk, men det bør underbygges nærmere i senere studier. Sammenligningerne mellem de nordiske lande viser, at registreringsafgifter i Danmark og Norge ikke har medført, at der er en ældre bilpark her end i Sverige. Den gennemsnitlige alder for personbiler varierer med tiden, men er grundlæggende den samme. Ønsket om at fremme en hurtig udskiftning af bilparken kan således ikke bruges som argument imod at have en registreringsafgift - eller for at afgifterne skal lægges på brug af bilen frem for på køb og eje af bil.

\section{DEL V: 2. Beskatning af varebiler brugt til personkørsel og af personbiler i firmabrug}

Reglerne for beskatning og skattefrihed er indviklede og meget forskellige i landene. Men gennemgående er det, at firmabiler købes i vidt omfang, at størrelse og miljøbelastning er stor. Også brændstofforbrug er billigt på grund af fradrags- og beskatningsregler uden indbyggede miljøincitamenter, jf. gennemgang af de enkelte landes afgiftssystemer, del II 1-5. For eksempel er 35-40 \% af et års bilkøb nu "erhvervsbiler" i Danmark og Sverige - og her er ingen afgiftsdifferentiering ud fra miljøhensyn, hverken i Danmark eller Sverige.

Det har ikke været muligt inden for rammerne af projektet at skaffe generelle data for brugen af firmabiler til private formål. Der er ingen tvivl om, at det sker i betydeligt omfang - der er også gjort visse forsøg på at stramme op. Og der er heller ingen tvivl om, at en del borgere kommer ganske billigt til transport på denne måde, og at de miljømæssige hensyn i ordningerne er svage.

Firmabil, brændstof

For firmabiler i Sverige betyder skattereglerne, at medarbejderen netto kan slippe med omkring $60 \%$ af normalprisen.

Firmabil, salg og bestand

De gældende afgiftssystemer indebærer generelt, at der ikke tages de samme miljømæssige hensyn for erhvervsbiler som for private personbiler.

Afgiftsniveauerne er ikke afhængige af miljøpåvirkning, og afgifterne er i det hele taget lave, så erhvervsbiler købes og videresælges med meget kort tidshorisont. Erhvervsbilerne udgør en meget stor andel (typisk 30-40 \% af nybilsalget), og disse er ikke underlagt væsentlig miljømæssig påvirkning via afgifter. 


\begin{tabular}{|c|c|c|c|}
\hline & Salg & Bestand & Ar \\
\hline Danmark & $38 \%$ & $7,2 \%$ & 2007-08 \\
\hline Finland & *) $25 \%$ & & \\
\hline \multicolumn{4}{|l|}{ Island } \\
\hline Norge & $32 \%$ & $11,3 \%$ & $\begin{array}{l}\text { Salg: } 2008 \\
\text { Bestand: } 2006\end{array}$ \\
\hline Sverige **) & $35-40 \%$ & $6 \%$ & 2007 \\
\hline
\end{tabular}

Tabel 72. Firmabiler som andel af det årlige salg og af bestanden.

*) af de $25 \%$ er 3 ud af 4 "frie", det vil sige også til privatbrug

**) Af de svenskproducerede biler er det 70-90\%, der sælges som firmabiler.

Anskaffelsesmulighederne for firmaer er åbenbart er så gunstige, at typisk 35$40 \%$ af hele vognparken købes som firmabiler - ofte store og energiforbrugende pga. skatte- og afgiftsreglernes manglende differentiering efter miljøpåvirkning. Men i løbet af få år bliver bilerne i vidt omfang omregistreret til privatbiler. Der er både et socialt fordelingspolitisk og et miljømæssigt problem her.

Der er desuden et problem med privat (afgiftslettet) kørsel i firmabiler ofte med skattemekanismer, så de ansatte føler, at jo mere de kører, jo større løntilskud får de, jf. f. eks. svenske regler. 


\section{DEL V: 3. Andre afgifter og skatter herunder kørselsafgifter}

En særdeles effektiv måde at begrænse trafikomfanget og øge anvendelsen af energieffektive køretøjer mv. i teorien vil være at lægge afgifter fra eje af bil til $k ø b$ af drivmidler. Imidlertid er grænsehandelsproblematikken $i$ vejen her især i Danmark. Der kan ikke f.eks. være radikale prisforskelle mellem benzin i Danmark og Tyskland. I procent af den samlede benzinhandel er det måske nok beskedent for privatbiler, hvad der kunne handles i et naboland, men dette har vist sig også at blive er politisk problem. Der må samlede løsninger til - eventuelt via EU.

Men Tyskland har i dag 19 og 28 \% højere punktskatter end Danmark på henholdsvis benzin og diesel. Forskellene i salgspriser er dog langt mindre (og faktisk på niveau for diesel), se tabel 74. Det må antages, at afgifterne i Danmark kan forhøjes til eller lidt over tysk niveau uden væsentlige grænsehandelsproblemer, se del II, afsnit 1.3. Derved vil avancerne sikkert falde, men udsalgsprisen vil hæves lidt, og en effekt på energiforbruget må antages at indfinde sig. Dette vil givetvis være en god løsning, men langt fra tilstrækkelig i klimasammenhæng.

\begin{tabular}{lrrrr}
\hline euro/1000 I & $\begin{array}{r}\text { Benzin, } \\
\text { punktskat }\end{array}$ & $\begin{array}{r}\text { Benzin, } \\
\text { pris }\end{array}$ & $\begin{array}{r}\text { Diesel, } \\
\text { punktskat }\end{array}$ & $\begin{array}{r}\text { Diesel, } \\
\text { pris }\end{array}$ \\
\hline Tyskland & 654,50 & 1441,50 & 470,40 & 1360,17 \\
Danmark & 550,13 & 1435,21 & 366,57 & 1360,00 \\
Sverige & 552,41 & 1373,06 & 442,27 & 1426,52 \\
Finland & 611,31 & 1417,42 & 330,12 & 1233,63
\end{tabular}

Tabel 73. Oil Bulletin http://ec.europa.eu/energy/oil/bulletin/2008_en.htm

Derimod er afgifter på bilkøb (og effektive ordninger for privat køb af bil i udlandet) samt kørselsafgifter egnet til at tackle denne problematik.

\section{Kørselsafgifter}

I denne rapport ses på økonomiske instrumenter til påvirkning af $\mathrm{CO}_{2}$-belastningen af klimaet. En af de væsentlige metoder i den sammenhæng er kørselsafgifter i forskellige udformninger. Der ses alene på bompengeordninger, fordi egentlige road pricing-systemet ikke findes i drift endnu i sammenlignelige områder. Men blandt andet forberedelserne til indførelse af et landsdækkende road pricing-system i Holland fra 2011-18 peger på, at dette instrument er endnu mere relevant i $\mathrm{CO}_{2}$-sammenhæng. Der ses i denne rapport alene på ordningerne i Oslo, Stockholm og London. Vi har valgt at medtage London, da der kun findes få eksempler i de nordiske lande. 
Inden for bomområde Region / län CO2-reduktion

\begin{tabular}{l|l|l|l} 
Oslo & $3-5 \%$ i bomsnittet & & \\
\hline Stockholm & $15 \%$ & $1,3 \%$ & $\begin{array}{l}\text { CO2-reduktion lidt større end de trafikale ændringer } \\
\text { pga. højere hastigheder }\end{array}$ \\
\hline London & $\left.{ }^{*}\right)$ & $21-15 \%$ & $\begin{array}{l}\text { Der er CO2-reduktion i de to hidtidige afgiftsområder, } \\
\text { bla. 16\% i oprindeligt charge område og yderligere } \\
\text { ventes 5.000 tons CO2 sparet pr. år efter en omlæg- } \\
\text { ning fra okt. 2008 med større differentiering efter } \\
\text { bilens miljøbelastning }\end{array}$ \\
\hline
\end{tabular}

Tabel 74. Trafikal og CO2-effekt af bompengesystemer.

*) I henholdsvis det oprindelige congestion charge-område på $23 \mathrm{~km}^{2}$ og i udvidelsesområdet af omtrent samme størrelse

Sammenfattende kan siges, at bompenge reducerer biltrafikken, men med varierende styrke afhængigt af udformning og takstniveauer, se tabel 75 . Stockholms system havde i udgangspunktet som hovedmål at reducere miljøbelastning og trængsel i byen. Efter den permanente indførsel af systemet i 2007 er indtægterne øremærket til vejudbygning. Man har altså indført et fiskalt mål. Ikke desto mindre er systemet etableret på en måde, så der sker visse reduktioner i biltrafikken. Oslos system er af mere fiskal art og har kun haft begrænset trafikregulerende betydning.

\section{Bomringen i Oslo}

Bomringen i Oslo blev oprettet i 1990. Den fungerer sådan, at bilister som kommer kørende ind til Oslo må betale en afgift, afhængig af størrelse på køretøjet som vist i tabel 76, til myndighederne. Bomring-området er vist på figur 30. Bomringen i Oslo har været kontroversiel og skulle afvikles først 1997 og så senere i 2007 . Men i Oslopakke 3 blev den præsenteret igen som en tidsafgrænset indtægtskilde, som skal være med til at finansiere tiltag i Oslo i yderligere 20 år. I denne pakke er fordelingen på vej- og kollektiv trafik-projekter endnu ikke fastlagt, men 50 \% til kollektiv trafik er foreslået.

Bomringen har finansieret en række projekter i Oslo-området, blandt andet tunneler på E18 og Ring $1 .{ }^{8}$ Før har vejprojekter fået $80 \%$ af indtægterne fra bomringene, men i dag går $50 \%$ af indtægterne til drift af kollektiv trafik, mens 50 \% går til nye vejprojekter. Ifølge Transportøkonomisk Institut går kun $30 \%$ af alle bilrejser i Oslo og Akershus gennem bomringen. ${ }^{9}$

Tabell 75 Priser på bomringen i Oslo 2008. Kilde: Fjellinjen $A A^{10}$

http://no.wikipedia.org/ wiki/Bomring

9 http://www.sak.oslo.kommune.no/dok/Bys\% ${ }_{5} \mathrm{C}_{2004 \%} \mathrm{C}$ SFK\% 5 C2004007993-1.htm 10 https://www.fjellinjen.no/ Faktura_og_betaling/gjeldende_takster/no 
11 http://www.vegvesen.no/ cs/Satellite?blobcol=urlpdf\& blobheader=applica

tion\% 2 Fpdf\& blobkey=id\& $b$ obtable $=S V V$ vedlegg\&blob where $=1197038833567 \& s s$ inary $=$ true

12 http://www.akershus.no /index.php?page_id=304\&a rticle_id $=3688$

13 http://www.toi.no/ getfile.php/Publikasjoner/T $\%$ D $81 \%$ 2orapporter/2005/770-2005/rap port.pdf

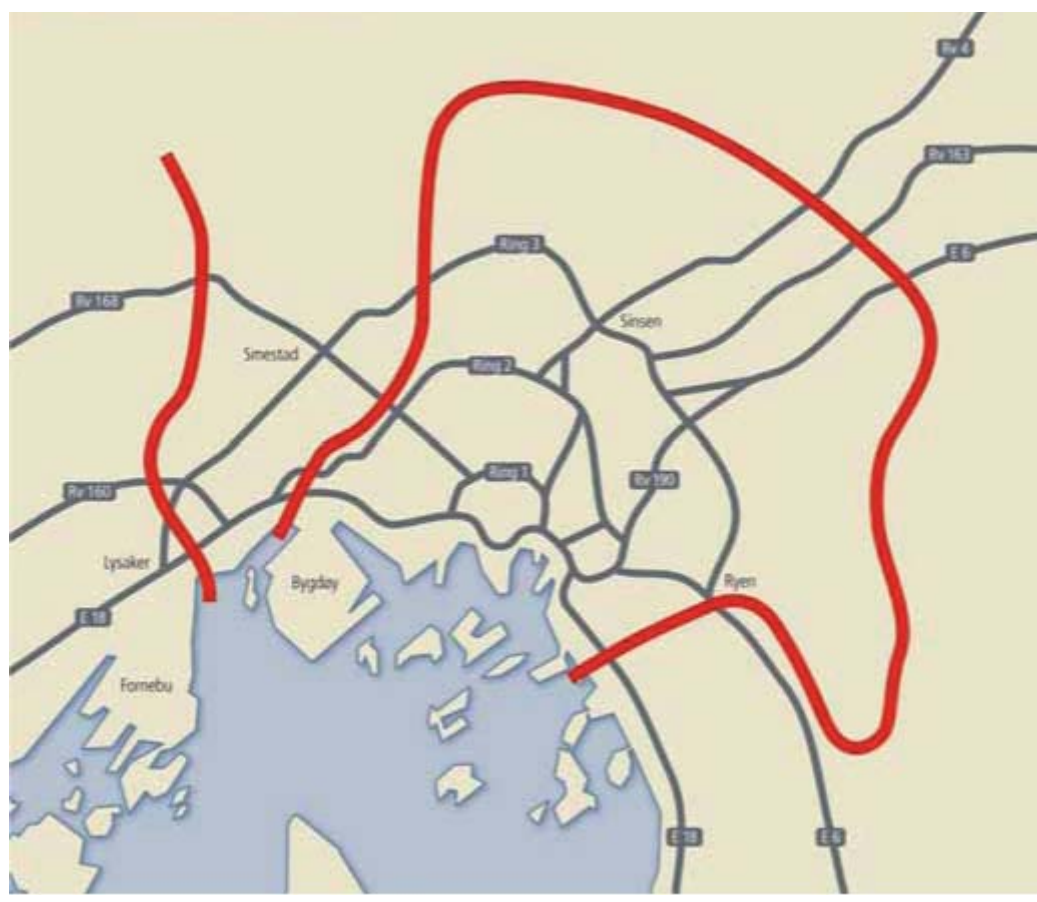

Figur 30. Bomringen i Oslo. Der skal betales for at passere sløjfen til højre. Desuden indføres med Oslopakke 3 en yderligere betaling ved passage af linien til venstre. Kilde: "Konseptvalgutredning Oslopakke $3 " .{ }^{11}$

Skepsissen til bompengeringen var stor før ringen åbnede, men er siden reduceret. Deraf kan sluttes, at brugerbetaling i højere grad er accepteret i dag. ${ }^{12}$ Bomringen i Oslo passeres dagligt af omkring 245.000 biler pr. retning, der betales kun i én retning. Studier har antydet, at der er afvist omkring 3-5 \% af trafikken som følge af indførelsen af bomringen i Oslo ${ }^{13}$. Ifølge

Transportøkonomisk institut er herudover sket nogle omfordelinger i Oslo med en trafikvækst på hovedvejene og ikke på lokalvejene som følge af byggeri af nye store hovedveje. Dette er i tråd med målsætningen med bomringen, idet det var ideen at lede trafikken væk fra områder, hvor folk bor og opholder sig.

\section{London}

Fra 2001 har der været betalt congestion charge - afgift for kørsel med bil i det centrale London $\left(23 \mathrm{~km}^{2}\right)$. Der betales $8 \mathrm{f}$ pr. døgn for kørsel i området. I 2005 blev området næste fordoblet med et område vest for det centrale London.

Fra oktober 2008 indføres emissionsrelateret trængselsafgift, hvor der pr. dag betales:

o $f$ for køretøjer med emissioner på op til $120 \mathrm{~g} \mathrm{CO}_{2}$ pr. kørt km og som overholder EURO IV-standard for emission

$25 \mathrm{f}$ for køretøjer der udleder mindst $226 \mathrm{~g} \mathrm{CO}_{2}$ pr. kørt km, samt for køretøjer med en motorkapacitet på mindst $3001 \mathrm{cc}$ $8 \mathrm{f}$ for øvrige køretøjer. 
I maj 2008 er der dog valgt en konservativ borgmester, som har varslet visse ændringer. Den 8. juli 2008 har borgmesteren meddelt, at denne differentiering af afgiften trækkes tilbage - efter at Porsche havde varslet en retssag. ${ }^{13 a}$

\section{Effekt}

Det vurderes, at afgifterne har ført til en $16 \%$ reduktion i $\mathrm{CO}_{2}$ emissioner i det oprindelige charge-område. Trafikmængden i samme område er fortsat omkring 21 \% lavere end før afgifternes indførsel. I det vestlige udvidelsesområde er trafikmængderne reduceret med $15 \%$. Siden 2005 har der været en vis øget trængsel i centralområdet, men altså fortsat en 21 \% reduktion i trafikmængder. Der er også en vis vækst i trafikmængderne helt lokalt uden om afgiftsområdet. Men dette $g ø r$ ikke den samlede $\mathrm{CO}_{2}$-reduktion i regionen væsentligt mindre. Med det nye system, som indføres fra oktober 2008 forventes en yderligere

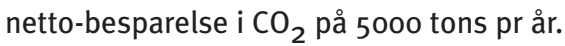

\section{Stockholm}

I Stockholm er der indført "Trängselskatt”. Siden 1. august 2007 skal køretøjer, som færdes ind eller ud af Stockholms centrum, betale trængselsskat til staten - se figur 31. Skatten betales mandag-fredag 06.30-18.30 og er 10, 15 eller 20 sv kr. pr. passage. Højest er skatten i myldretiden om morgenen og om eftermiddagen. Pr. døgn er skatten maximeret til 60 sv kroner pr. køretøj. Undtaget fra skatten er bla. større busser (over 14 ton), udrykningskøretøjer, handikapkøretøjer og køretøjer, som kan drives på ethanol og gas samt el- og hybridbiler.

Trængselsskatterne har betydet, at vejtrafikarbejdet i Stockholms innerstad er mindsket med ca. $15 \%$ og i Stockholms län med 1,3\%. Udslippet af $\mathrm{CO}_{2}$ er mindsket i cirka samme omfang.

$13 a$ Borgmester Boris Johnson på www.telegraph.co.uk d. 8.7.2008

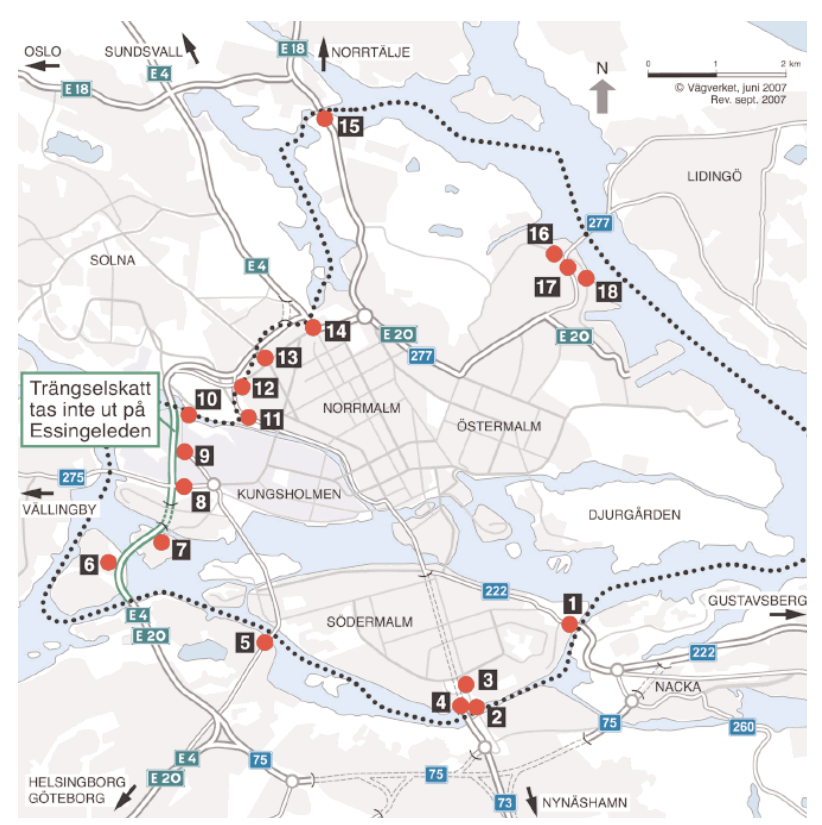

Figur 31. Trængselsskatteområde i Stockholm 


\section{Konklusion om kørselsafgifter/trængselsskatter}

Kørselsafgifter kan tilrettelægges efter forskellige formål og på forskellige måder. Hvis ønsket er at reducere områdets $\mathrm{CO}_{2}$-emission er det muligt. Det lykkes bedst, hvis der samtidig sørges for tilstrækkelig kollektiv trafik med høj kvalitet. De afgiftsbelagte områder i storbyerne er nok forholdsvis små set i det store perspektiv, men der er meget store trafikmængder i områderne, så det kan godt have mærkbar betydning.

Kørselsafgifter i storbyområder kan være 1. etape af indsatser på længere sigt, hvor der senere etableres road pricing i større områder, lande for eksempel.

\section{Skattefradrag for kørsel til arbejde}

Reglerne for skattefradrag er ganske forskellige i de nordiske lande.

\section{Principper}

Km-fradrag uafhængigt af transportmiddel.

Ved store afstande falder $\mathrm{km}$-fradrag. Udkantsområder: intet fald ved lange afstande.

Erhvervsmæssig kørsel i egen bil. Skattefrihed

Finland Fradrag i beskatningsbar indkomst for billigste rejsemulighed. Max 52.197 kr. i fradrag pr. år

\begin{tabular}{ll}
\hline Island & \\
\hline Norge & $\begin{array}{l}\text { Fradrag uafhængigt af de faktiske rejse- } \\
\text { omkostninger. Fuldt fradrag ved sam- } \\
\text { kørsel }\end{array}$ \\
\hline Sverige & $\begin{array}{l}\text { Fradrag for udgift over } 6.362 \mathrm{kr} \text {. ved } \\
\text { mindst } 2 \text { km's afstand til job hver vej, } \\
\text { biludgifter kan fratrækkes, hvis der kan } \\
\text { spares } 2 \text { timer ved bilkørsel }\end{array}$ \\
\end{tabular}

\section{Fradrag pr kilometer}

Pr dag: $0-24 \mathrm{~km}$ intet fradrag 25-100 km 1,83 kr. pr. km Over 100 km 0,92 kr. pr. km Udkantsområder: alt ud over $24 \mathrm{~km}: 1,83$ $\mathrm{kr} / \mathrm{km}$

Erhvervskørsel: fradrag på 3,47/1,83 kr./km for over og under $20.000 \mathrm{~km} / \mathrm{a} r$

1,64 kr. pr. km for bilkørsel, hvis der ikke er adgang til kollektiv trafik

kr. 1,32 pr. km (kr. 0,65 pr. km for rejser over $35000 \mathrm{~km}$ per år). Dog bundfradrag på kr. 12.030 (indtægtsåret 2006)

Egen bil: $14,71 \mathrm{kr} / 10 \mathrm{~km}$

Firmabiler hvor arbejdsgiveren ikke betaler drivmiddel 5,17 (diesel) eller 7,55 kr/10 km.

Tabel 76. Hovedprincipper for skattefradrag for kørsel mellem bolig og arbejdsplads, danske kroner 


\section{DEL V: 4. Subsidier til brug af alternative brændstoffer}

Skal det virke skal det være billigere. Erfaringerne fra studier af afgiftssystemer viser, at subsidier til produkter eller ydelser, som ønskes fremmet, normalt kun har tilstrækkeligt effekt, hvis de mere miljøvenlige alternativer bliver billigere eller i hvert fald ikke dyrere - end de gængse. Hvis tilskuddene bare indebærer, at prisen på mere miljørigtige produkter reduceres, men stadig er dyrere end de alternative og mindre miljørigtige produkter, så købes de ikke i ret vidt omfang. Et eksempel er afgiftslettelser for partikelfiltre i Danmark, som først virkede nogenlunde, da tilskuddet blev så stort, at der ikke længere var en merpris på nye biler med partikelfiltre. Da man i første omgang blot fjernede registreringsafgiften på filtrene, men bevarede den "rå" merpris virkede initiativet næsten ikke. Der er en del eksempler på denne sammenhæng.

Elbiler og vedvarende energi. I det seneste forslag til EU's klima- og energipakke er det tidligere krav om 10\% biobrændstoffer i transportsektoren i år 2020, blevet ændret til et krav om minimum $10 \%$ vedvarende energi. Dette giver mulighed for at udnytte den vedvarende energi også på tidspunkter af ugen eller dagen, hvor der normalt ikke afsættes så meget strøm. Det giver bedre muligheder for at udnytte især vindkraft, som jo producerer ligeså meget om natten som om dagen - og det er vanskeligt/dyrt at oplagre strøm til senere brug.

Her kan fremme af el-biler være en mulighed. Med lidt teknologisk udvikling automatisk styring - vil der kunne "tankes" op i bilerne f.eks. om natten, i weekenden, i frokostpausen, på helligdage, eller hvornår der måtte være lille efterspørgsel efter strøm.

Men udvikling af biltyper og skabelse af et marked i større skala for elbiler og plug-in-biler både til privatbiler og erhvervsbiler kræver offentlig fokus på området - og tilskud. I Danmark er der afgiftsfritagelse for el-biler frem til 2012. Der er initiativer, der sigter på at indføre elbiler i Danmark i stor skala. Men der må være længere perspektiv for afgiftsfritagelse end 2012. Det kan f.eks. være frem til 2018. En sådan forlængelse er formentlig på vej.

Der er gode muligheder for at etablere et stort antal vindmøller i Danmark i årene fremover, og samspillet med elbiler kan vise sig at være en stor fordel, som bla. kan give $\mathrm{CO}_{2}$-besparelse. Men også for en række andre vedvarende energikilder gælder, at de naturligt kan producere hele tiden, dvs. også på tidspunkter, hvor der normalt ikke afsættes ret meget strøm. Det kan være bølgekraft, solcellestrøm (producerer weekender, ikke nat) mv. - i visse tilfælde vandkraft, men denne kan bedre lukkes ned om natten, idet man kan holde vandet tilbage bag dæmninger.

14 Dvs. ethanol baseret på spiselige afgrøder som majs, korn, raps, sukker og palmeolie.
Bioethanol. Anvendelse af bioethanol har to formål: et forsyningssikkerhedsmæssigt (større uafhængighed af leverancer af olie) og et miljømæssigt.

Med hensyn til det miljømæssige er der en række problemer med især 1. generations bioethanol ${ }^{14}$, som $g ø r$, at fordelen er tvivlsom eller begrænset. Netto er $\mathrm{CO}_{2}$-fordelen tvivlsom. Både dyrkning og den industrielle fremstilling af bio- 
ethanol er forbundet med et relativt stort udslip af drivhusgasser. I nogle tilfælde indebærer dyrkningen rydning af regnskovsarealer - mest direkte ved produktion af palmeolie i Indonesien. Også transporten kan i nogle tilfælde bruge meget energi. Desuden er der en uheldig konsekvens for forsyning og priser på fødevarer i verden, når landbrugsjord eller produkter anvendes til bioethanolfremstilling.

Bioethanol bør derfor kun anvendes i tilfælde, hvor et fuldt miljøregnskab (livscyklus) viser tydelig $\mathrm{CO}_{2}$-besparelse, og der ikke anvendes materialer, som er egnet til fødevarer.

På sigt er 2. generations-bioethanol, med brug af affaldsprodukter, det eneste acceptable. Tilsvarende gælder for biodiesel. Men her er 2. generation allerede på markedet, fremstillet på animalsk fedtaffald. Dette fremstilles i Danmark, men eksporteres til Tyskland, hvor der er en afgiftsreduktion, som fremmer salget. Det bliver der måske også i Danmark inden længe.

Biogas: Specielt i Sverige anvendes der biogas i køretøjer - 0,4 \% af det samlede brændstofforbrug i vejtransporten (se del II). Dette kan betragtes på linje med 2. generation biobrændstoffer, idet det produceres på grundlag af affaldsprodukter. Det vil kunne have en mere positiv miljøeffekt end andre biobrændstoffer, idet det reducerer udslip af drivhusgasser fra f.eks. gylle og samtidig bevarer dens gødningsværdi. 


\section{DEL VI: Konklusion og sammenfatning}

Rapporten gennemgår skatte- og afgiftssystemer i de 5 nordiske lande, idet Finland og Island dog er behandlet mindre dybtgående end Danmark, Norge og Sverige.

Analyserne i denne rapport tyder på, at nogle afgifter er adfærdsregulerende andre ikke.

Bilkøbsafgifter har tilsyneladende klar sammenhæng til både antallet af bilkøb og især til arten af bilkøb. Små niveauer eller marginale ændringer af niveauet har ikke haft stor betydning for bilsalget. Men det absolutte niveau for bilkøbsafgift har betydning for bilejerskabet i et land. Først og fremmest er bilkøbsafgifter et effektivt instrument til påvirkning af de konkrete køb i mere miljørigtig retning.

De årlige ejerafgifter har næppe stor betydning hverken for omfanget af bilsalg eller modelvalg. Der kan være en vis betydning for skrotningshastighed, jf. del III,3, men dette er ikke markant og bilparkens alder i de nordiske lande - og ændringer i bilparkens alder med tiden - tyder på, at det faktisk ingen betydning har, jf. opsamlingen i afsnit V,1.

Brændstofafgifterne har til gengæld blandt andet betydning for kørselsomfang og i et vist omfang også for valg af biltype. For erhvervsbiler (herunder taxa) og varebiler kan der i flere af de nordiske lande - formentlig alle - gøres meget mere for at give incitament til $\mathrm{CO}_{2}$-besparende valg.

Differentierede afgifter virker

Der er konstateret mange eksempler. Her kan nævnes et par:

- Indførelse af differentieret bilaccis (registreringsafgift) i Sverige i 1987 betød hurtig indførelse af katalytisk udstødning.

- Engangsafgift i Norge og registreringsafgift i Danmark differentieres fra 2007 efter $\mathrm{CO}_{2}$-udslip/energiforbrug.

- Der var ingen $\mathrm{CO}_{2}$-afhængighed i Finland før i år, og derfor ingen effekt men en ændring med differentiering fra 1.1.2008 viser hurtige og tydelige effekter også her i form af faldende $\mathrm{CO}_{2}$-udslip i nye biler.

- Differentieret benzinpris i Danmark efter blyindhold udfasede næsten blyholdig benzin på kort tid i 9o'erne

- Lavere afgift på svovlfattig diesel har sikret hurtig og total omlægning i flere nordiske lande

Trængselsskatter/kørselsafgifter/bompenge kan anvendes med vidt forskellige formål, metode og resultat. Eksemplerne fra Stockholm og London viser, at der er mulighed for med sådanne afgifter at reducere trafikkens $\mathrm{CO}_{2}$-belastning mærkbart, hvis det kombineres med hensigtsmæssig udbygning af den kollektive trafik. Forberedelserne til indførelse af et landsomfattende system i Holland (fra 2011 for lastbiler og for personbiler fra 2018) tyder også på, at der er lovende perspektiver i nationale systemer.

Afgifter, som direkte hænger sammen med en mulighed for aktive købshandlin- 
ger ser ud til at rumme de bedste muligheder for adfærdspåvirkning. Samtidig skal afgifter have en vis størrelse for at virke adfærdsændrende. F.eks. var den svenske registreringsafgift - før den blev afskaffet sidst i 1990'erne - for lille til at have nogen væsentlig adfærdsændrende effekt. Det må anbefales, at der ses videre på disse hypoteser, med modelkørsler af udviklingsforløb ved de vigtigste gennemførte afgiftsændringer.

På grundlag af rapportens analyser er opstillet en række anbefalinger af tiltag, som kunne reducere $\mathrm{CO}_{2}$-udslip fra bilparken i de nordiske lande.

\section{Primære anbefalinger}

- registreringsafgift for bilkøb bør analyseres videre og kan formentlig anbefales som velegnet instrument til $\mathrm{CO}_{2}$-begrænsning, fordi der er tegn på en effekt for bilparkens størrelse, men først og fremmest fordi det er et glimrende instrument til påvirkning af forbrugsvalgene i $\mathrm{CO}_{2}$-reducerende retning, hvis afgifterne har en vis størrelse. Afgifterne bør være generelle, så visse trafikantgrupper ikke stilles væsentligt gunstigere, som ved de danske gulpladeordninger.

Differentieringen af taksterne bør være endda større end den, der gælder i Norge (som pt. er den største differentiering i Norden), f.eks. med billige biler for udslip på under $100 \mathrm{~g} / \mathrm{km}$ og dyre biler med udslip på over $140 \mathrm{~g} / \mathrm{km}$.

- Firmabiler bør gives større incitament til lille $\mathrm{CO}_{2}$-udslip, jf. at f.eks. svenske formånsbiler til godt $300.000 \mathrm{sv}$ kr. er det skattemæssigt mest fordelagtige. Det er en klar mangel, at bla. erhvervsbiler (herunder taxa) og varebiler ikke gives incitament til $\mathrm{CO}_{2}$-besparende valg. Der bør suppleres med aftale om ordning ved landeskift, så landeskift for bilejere er muligt, men så der heller ikke skabes en genvej til billige $\mathrm{CO}_{2}$-belastende biler fra andre lande. Vi vurderer, at der allerede nu er grundlag for at gennemføre tiltag til fremme af $\mathrm{CO}_{2}$-besparende erhvervskøretøjer. Men herudover er der behov for en mere systematisk gennemgang af skattereglerne for erhvervskøretøjer, end det har været muligt inden for dette projekts rammer.

- En samlet trafikreduktion i større byer er nødvendig

- Kørselsafgifter og parkeringsafgifter. Det anbefales, at der indføres trængselsafgifter i større byer, og efterhånden kørselsafgifter også på landsplan. Dette kan ske som en ekstra afgift, eller med modregning i ejerafgifter og benzinafgifter og evt. også delvist i registreringsafgifter. Ud fra de ovenstående reaktionsmønstre må det antages, at der også vil være klar påvirkning af kørselsomfang, transportmiddelvalg mv., hvis kørselsafgifterne differentieres efter $\mathrm{CO}_{2}$-udslip. Parkeringsafgifter og beskatning af gratis parkeringsmulighed ved firma bør også indføres generelt i byer.

- Drivmiddelafgifterne har en tydelig effekt på kørselsomfanget. Det er udmærket at påvirke til dieselkørsel, da det sparer $\mathrm{CO}_{2}$, men kun forudsat det sikres, at partikelforurening og $\mathrm{NO}_{\mathrm{x}}$-udslip ikke øges, dvs. at partikelfilter og katalysator bør være obligatorisk, -så problematikken med bl.a. nanopartikler håndteres

- Drivmiddelafgift på diesel og benzin. Priserne bør være på niveau med eller lidt over priserne i Tyskland. Af hensyn til grænsehandelsproblemer kan priserne især for lastbiler ikke være højere end i Danmark, men måske i de øvrige nordiske lande. 


\section{Sekundære anbefalinger}

- drivmiddelskat på diesel og benzin: større energiudbytte af en liter diesel medfører større eksternalitetsbelastning ud over $\mathrm{CO}_{2}$ pr. liter. Dette bør indgå i fastlæggelse af skatter og afgifter, men $\mathrm{CO}_{2}$ vejer tungest.

- Hovedvægt i anbefalinger bør ligge i tiltag, som gør noget ved klimaproblematikken

- Rejsefradrag for bolig-arbejdsstedsrejse mv. Fradragene bør være omkostningsuafhængige og med lille afstandsafhængighed. Fradrag tilskynder gennemgående til længere transport og højere omkostninger $=$ flere og større biler og lange transporter. Kilometer-afhængighed fremmer byspredning og øger $\mathrm{CO}_{2}$-udslip. Klima bør tænkes ind i reglerne, så der hverken er incitament til at købe miljøbelastende biler eller rejse langt.

\section{Det anbefales også at}

- forskelle i drivmiddelafgifter udjævnes mellem landene, f.eks. dieselskatters forskellighed fører til uhensigtsmæssig omvejskørsel og grænsehandel

- samarbejde f.eks. i Norden for at få billige systemer til "kilometerskattesystemer" for personbiler og lastbiler. Lastbilerne bør have ordning først.

- Der er ingen grund til at fremme udskiftningshastigheden af bilparken, dog kan der være en markant $\mathrm{CO}_{2}$-effekt, hvis der alene skiftes til biler med dieselmotorer. Dette kan dog have andre og uheldige miljømæssige konsekvenser, hvorfor der må være krav om partikelfilter og katalysator på dieselbilerne.

- følge Californiens eksempel, hvor der nu er forsøg med at betale arbejdstagere højere løn i stedet for gratis parkeringsplads. Dette har vist sig at være en vellykket strategi til at reducere brug af privatbil til arbejde. Dette forsøg bør også udføres i de nordiske lande. 


\section{English summary}

This document examines possibilities to reduce climate effects from private and commercial traffic primarily by fees and taxes. It is financed by The Nordic Council of Ministers, Department for Environment and Economy.

The task was being accomplished by cooperation between The Ecological Council in Denmark, The Swedish Society for Nature Conservation and Friends of the Earth Norway. It was done in cooperation between Hans Ege and Christian Ege (The Ecological Council, Denmark), Torhildur Kristiansdottir and Holger Schlaupitz (Friends of the Earth Norway), Magnus Nilsson (Swedish Society for Nature Conservation), and with participation of Erja Heino, The Finnish Association for Nature Conservation, and Orkusetur and Umferdastofa in Iceland.

The document takes a close look at the fee- and tax system in the five Nordic countries, though Finland and Iceland are dealt with in less details than Denmark, Norway and Sweden.

The analyses in this report seem to show that some fees do modify behaviour others don't.

Fees on car purchase are seemingly clearly connected to both number of purchases and in particular type of purchase. Low levels of fees or small differences in levels do not have any significant effect on car sales. But the absolute level of car purchase fees does affect car ownership in a country. Car purchase fees are first and foremost an effective instrument to influence actual purchases into a more environment friendly direction.

The annual motor taxes hardly have big importance for neither the number of car sales nor the choice of car model. There might be some, though not considerable impact on the scrap rate. And the average vehicle age in the Nordic countries - and the changing vehicle age over time - indicates no relevance of the size of motor taxes.

Fuel taxes on the other hand do, among other factors, influence overall mileage, as well as the choice of car model to some degree.

Regarding commercially used cars (including taxis) and trucks, a lot more can be done to incite $\mathrm{CO}_{2}$-decreasing choices in most, if not in all Nordic countries.

Differential fees do work

Many examples illustrate this fact. To mention a few:

- In Sweden in 1987, introduction of differential registration fees resulted in rapid introduction of catalytic converters.

- The registration tax in Denmark and Norway are differentiated according to $\mathrm{CO}_{2}$ - emission/fuel consumption as of 2007 .

- There was no $\mathrm{CO}_{2}$-dependance in Finland prior to this year and therefore no effect - but also here a change to differentiation as of January 2008 shows rapid and clear effects in decreasing $\mathrm{CO}_{2}$-emission of new cars. 
- In Denmark in the 1990 'ies, petrol prices were differentiated according to lead content, which nearly eliminated leaded petrol after a short time.

- Lower taxes on low-sulfur diesel secured rapid and complete conversion in several Nordic countries.

'Congestion charges/mileage fees/road pricing can be applied with very different goals, methods and results. Examples from Stockholm and London show that this kind of fees might reduce $\mathrm{CO}_{2}$. pollution considerably, if combined with adequate improvement of public transport. Preparations to introduce a nationwide system in Holland (from 2011 for trucks and from 2018 for private cars) also indicate that nationwide systems are promising.

Those fees that are directly connected to an actual purchase seem to have the biggest influence on consumer behaviour. At the same time, fees need to have a certain size in order to modify consumer behaviour. E.g. the Swedish registration fee was - prior to its elimination in the late 1990iess - too small to have a considerable impact. We recommend to take a closer look at these hypotheses, applying development models for the most important changes in traffic-related fees.

Based on the analyses in the document we recommend a number of actions that could reduce $\mathrm{CO}_{2}$-emission from the transport sector in the Nordic countries.

\section{Primary Suggestions}

- Registration fees on purchase of new vehicles should be analyzed further and can probably be recommended as a useful instrument for $\mathrm{CO}_{2}$-reduction. They might affect the size of the total number of vehicles, but mainly because they influence consumers to make $\mathrm{CO}_{2}$-reducing choices, provided that the fee has a certain size. The fees ought to be applied generally, as not to considerably favour certain groups of vehicles, as seen with the yellow numberplate rules ${ }^{1}$ in Danmark.

- Differentiation of fees should be even wider than in Norway (which at the moment has the biggest differentiation in Scandinavia), e.g. by making cars with emissions of less than $100 \mathrm{~g} / \mathrm{km}$ cheap and those with emissions of more than $140 \mathrm{~g} / \mathrm{km}$ expensive.

- Commercially used vehicles should be pushed more into low $\mathrm{CO}_{2}$-emission.E.g. today cars in Sweden at a price of around 300000 Swedish Kroner are tax-wise the best choice. It is clearly a drawback that commercial cars (including taxis) and vans are not pushed into being more $\mathrm{CO}_{2}$-friendly. This should be connected to a border-agreement, such that it is possible to move a vehicle into another country, but without any possibility to import $\mathrm{CO}_{2}$-heavy vehicles from other countries.

- In bigger cities an overall reduction of traffic is necessary.

- Mileage tax and parking fees We recommend to introduce congestion charge in bigger cities and in time also nationwide mileage tax/roadpricing. This could be an extra tax or be off set against motor tax, petrol tax and partly also registration taxes. In 
line with the behaviour patterns stated above, it must be assumed that the overall level of mileage, choice of means of transport and other things would be influenced, if mileage taxes were differentiated according to $\mathrm{CO}_{2}$ emissions. Parking fees and taxation of free company parking space should generally be introduced in cities.

- Fuel taxes have a considerable effect on overall mileage. Pushing for a larger amount of diesel engine vehicles is fine in terms of $\mathrm{CO}_{2}$-emission, provided that pollution by particles and $\mathrm{NO}_{\mathrm{x}}$-emissions is not increased. That means that particle filters and catalic converters should be obligatory, such that the issue of nano-particles is taken care of.

- Fuel taxes on both diesel and petrol

Prices should be approximately at the level in Germany or slightly higher. Because of problems with cross-border trade, prices in Denmark cannot be much higher than in Germany, while the other Nordic countries probably do not have big problems with cross-border trade.

\section{Secondary Suggestions}

- Fuel taxes on diesel and petrol: Higher energy yield in diesel fuel means, apart from $\mathrm{CO}_{2}$, more external pollution - and therefore external costs - per litre diesel than per litre petrol. This fact should be taken into account in the level of fees and taxes, but $\mathrm{CO}_{2}$ is still the most important factor.

- Recommendations for traffic should weigh the climate problem highest.

- Transport allowance (Tax allowance for commuting between home and work place)

Transport allowance should be given independent of the actual cost and only with small regard to distance. Transport allowance generally incites to longer transport and higher cost, resulting in more and bigger cars and more mileage. Given according to mileage, transport allowance encourages suburbanization (more scattered habitation) and increases $\mathrm{CO}_{2}$-emission. The climate issue should be taken into account in taxation rules in a way that neither heavily polluting cars nor long distance travel are promoted.

\section{We further recommend}

- that differences in fuel tax are eliminated internationally, since e.g. differences in diesel tax lead to unnecessary detours and border-trade.

- Cooperation, e.g. in Scandinavia to establish cheap mileage-tax systems/road pricing for cars and trucks. Trucks should be given first priority.

- There is no reason to increase vehicle scrap rates, although there could be a considerable $\mathrm{CO}_{2}$-effect of all vehicles being replaced with diesel models. But this might lead to other and unfortunate environmental consequences. Therefore particle filters and catalists (SCR) must be required for all diesel vehicles.

- to follow Californias example, where tests are undertaken to give employees higher salary instead of free parking space. This has proven to be a successful strategy to reduce the use of private cars for commuting. This experiment should be done in the Nordic countries as well. 